\title{
"A Matter of Deep Personal Conscience": The Canadian Death-Penalty Debate, 1957-1976
}

\author{
by
}

Joel Kropf, B.A. (Hons.)

\author{
A thesis submitted to \\ the Faculty of Graduate Studies and Research \\ in partial fulfilment of \\ the requirements for the degree of \\ Master of Arts \\ Department of History \\ Carleton University \\ Ottawa, Ontario \\ July 31,2007 \\ (C) 2007 Joel Kropf
}




$\begin{array}{ll}\begin{array}{l}\text { Library and } \\ \text { Archives Canada }\end{array} & \begin{array}{l}\text { Bibliothèque et } \\ \text { Archives Canada }\end{array} \\ \begin{array}{l}\text { Published Heritage } \\ \text { Branch }\end{array} & \begin{array}{l}\text { Direction du } \\ \text { Patrimoine de l'édition }\end{array} \\ \begin{array}{l}\text { 395 Wellington Street } \\ \text { Ottawa ON K1A ON4 }\end{array} & \begin{array}{l}\text { 395, rue Wellington } \\ \text { Ottawa ON K1A ON4 } \\ \text { Canada }\end{array}\end{array}$

Your file Votre référence ISBN: 978-0-494-33745-5 Our file Notre référence ISBN: 978-0-494-33745-5

NOTICE:

The author has granted a nonexclusive license allowing Library and Archives Canada to reproduce, publish, archive, preserve, conserve, communicate to the public by telecommunication or on the Internet, loan, distribute and sell theses worldwide, for commercial or noncommercial purposes, in microform, paper, electronic and/or any other formats.

The author retains copyright ownership and moral rights in this thesis. Neither the thesis nor substantial extracts from it may be printed or otherwise reproduced without the author's permission.
AVIS:

L'auteur a accordé une licence non exclusive permettant à la Bibliothèque et Archives Canada de reproduire, publier, archiver, sauvegarder, conserver, transmettre au public par télécommunication ou par l'Internet, prêter, distribuer et vendre des thèses partout dans le monde, à des fins commerciales ou autres, sur support microforme, papier, électronique et/ou autres formats.

L'auteur conserve la propriété du droit d'auteur et des droits moraux qui protège cette thèse. $\mathrm{Ni}$ la thèse ni des extraits substantiels de celle-ci ne doivent être imprimés ou autrement reproduits sans son autorisation.
In compliance with the Canadian

Privacy Act some supporting forms may have been removed from this thesis.

While these forms may be included in the document page count, their removal does not represent any loss of content from the thesis.
Conformément à la loi canadienne sur la protection de la vie privée, quelques formulaires secondaires ont été enlevés de cette thèse.

Bien que ces formulaires aient inclus dans la pagination, il n'y aura aucun contenu manquant.

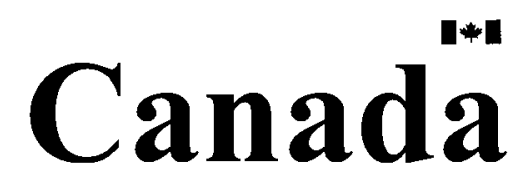




\begin{abstract}
This thesis explores the public debate in Canada concerning the death penalty during the two decades preceding its abolition in 1976, with a particular focus upon the role that the prevailing moral culture of the day played in shaping debate rhetoric. Some of the best existing scholarship reveals that the instrumentally and procedurally focused aspects of many Canadians' thinking in the third quarter of the century helped significantly to facilitate the eventual abolition of capital punishment. This study, however, highlights the wide range of ways in which debaters' discourse, including discourse with an instrumentalist flavour, resulted from or conveyed their moral perspectives. Both the nature of debaters' moral assumptions and the manner in which they were communicated suggest that moral ideas to which some Canadians sought to assign transcendent status possessed a weakened cultural credibility during this period, while moral perspectives animated by perceptions or expectations of progress exercised important cultural influence.
\end{abstract}




\section{Acknowledgments}

Special thanks to my supervisor, Dr. Brian McKillop, for his patience and encouragement as I have meandered forward through this project over the past year. His nudges at an early stage to take the research in a slightly different direction than I had originally envisioned turned this into a more well-rounded and interesting project to work on. His unfailing willingness to take time to talk despite the busyness of chairing the Department was truly appreciated, and his sense of humour is always refreshing.

Thanks to Mom and Dad for their tolerance and supportiveness as I've spent yet more time going to school and burying my nose in sometimes-narrow historical topics. This initial dip into graduate work has provided reminders of how much I have benefitted from their encouragement and prayers throughout my time in university.

The financial support of the Social Sciences and Humanities Research Council of Canada during the first year of this degree and research project is gratefully acknowledged, as is the support that the Ontario Graduate Scholarship Program provided during year two.

I owe thanks to each of the faculty members at Carleton from whom I've taken a class or for whom I've served as a TA; all have provided encouragement and important learning opportunities. The same is true of faculty at my undergraduate alma mater, Trinity Western University. Thanks are especially due to Dr. Bruce Shelvey, whose supportiveness at that stage did much to open up the further opportunities that have come along.

Finally, the quotation that appears in the title of this thesis is not included anywhere in the actual body of the thesis, and so this is an appropriate place to acknowledge the source of the quote. The phrase "a matter of deep personal conscience" is drawn from page 4077 of House of Commons Debates for the Second Session of the Twenty-Seventh Parliament, from the transcription of federal Solicitor General Larry Pennell's November 9, 1967 speech on anti-death-penalty legislation. 


\section{Table of Contents}

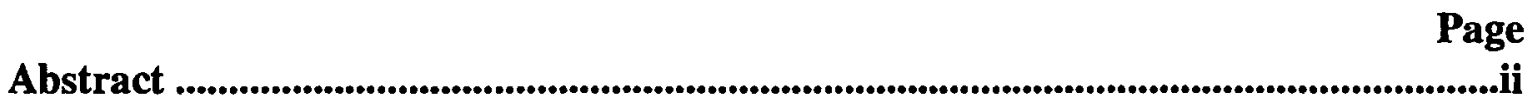

Acknowledgments .............................................................................................................................iii

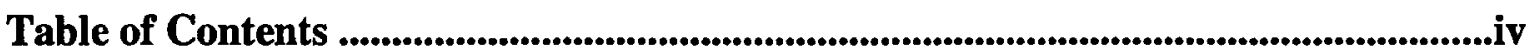

Chapter 1: Introduction........................................................................................................................1

Historical Context: Execution, Commutation, and Christmastime Robberies ...............3

The Historiography of Death-Penalty Debates ..............................................................19

Methodology and Argument .......................................................................................23

Chapter 2: To Deter or Not To Deter: How That Became the Question ......................35

Catholic Thought and the Common Good .................................................................41

Retribution and Its Opponents ......................................................................................53

Chapter 3: Victims, Murderers, and the Rest of Us: Moral Evaluation Via

Statements of Contrast and Assignment of Priority .......................................................91

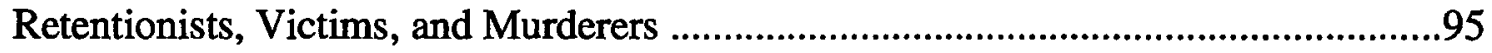

Abolitionists, Murderers, and the Rest of Us..............................................................108

Chapter 4: Responsibility, Psychology, Animality: Images of Human Nature in the

Death-Penalty Debate .........................................................................................................124

Freedom and the Responsible Human ...............................................................131

Psychology, Psychiatry, and the Mysterious Human ……….......................................146

Psychology, Animality, and the Impulsive Human ...................................................154

Animality and the Dangerous/Wicked Human ......................................................170

Chapter 5: Permissiveness and Public Opinion: Interpretations of Social Trends and Citizens' Attitudes in the Debates of the 1970s .................................................................183

Deterrence and Statistical Interpretations of Crime ...............................................192

Rhetorical Interpretations of Crime: Permissiveness in Three Flavours .....................210

Permissiveness as Moral Decay ....................................................................212

Permissiveness and Violence .........................................................................216

Permissiveness in Criminal Justice .................................................................221

Pragmatic, Retributive, or Bloodthirsty? Interpretations of Retentionist Public 
Opinion

Chapter 6: Conclusion ........................................................................................................................259

Bibliography 


\section{Chapter 1: Introduction}

In 1976, Canadian legislators instituted a death-penalty-free version of the criminal code. A great deal of heated argument over the idea of abolishing the death penalty had occurred among parliamentarians and within the citizenry writ large at various points during the preceding twenty-five years. In debating capital punishment, Canadians addressed a variety of issues by means of a variety of rhetorical themes. Many of these issues and themes replicated the discourse that had emerged in death-penalty debates in various other societies and at multiple historical junctures. A few facets of debaters' rhetoric expressed ideas especially meaningful to the citizenry during this particular period. A few tropes employed concepts or images that historians tend not to analyze. This thesis will examine a number of the issues, ideas, and rhetorical features that appeared in the debate, and will attempt to show why Canadians pursued such themes as they argued about capital punishment between the late 1950s and the mid-1970s.

As we will see with respect to the 1970s in particular, certain information and events emerging during the period of study influenced debate rhetoric in important ways. However, this thesis especially seeks to explore the role that the prevailing moral culture of the time played in shaping the debate. Some of the best existing scholarship reveals that the instrumentally and procedurally focused aspects of many Canadians' thinking in the third quarter of the century helped significantly to facilitate the eventual abolition of capital punishment. This study, however, highlights the wide range of ways in which debaters' discourse, including discourse with an instrumentalist flavour, resulted from or conveyed their moral perspectives. This is not, of course, to say that Canadians bought 
into all versions of moral thinking equally readily. The nature of debaters' arguments suggests that moral ideas to which some Canadians sought to assign transcendent status possessed a weakened cultural credibility during this period. On the other hand, moral perspectives animated by perceptions or expectations of progress exercised important influence. This combination of weakened cultural confidence in the first type of moral claim and significant esteem for the second type of moral perspective helped to shape both the moral ideas debaters espoused and the rhetorical themes by which they communicated their beliefs.

The latter stages of this introductory chapter will outline these arguments more fully, after discussion of some of the literature that has helped to stimulate them. Various scholars have indeed written about debates that have occurred in Canada or other nations concerning capital punishment as a general policy. However, in the past two decades, Canadian historians have more frequently written about death-penalty-related events other than the general debate over the penalty's proposed abolition. Most of this latter historiography deals with earlier periods and the capital-punishment dynamics specific to those eras. Nevertheless, the period dealt with in the present study also helps to illustrate why scholars have found it useful to examine matters beyond the philosophical ruminations and rhetorical efforts of abolitionists or retentionists. ${ }^{1}$ While a great deal of verbal and written advocacy regarding capital punishment made its presence felt in the public sphere during the 1957-1976 time frame, so did a variety of murders, death

\footnotetext{
'In this thesis, the terms "retentionist" and "abolitionist" refer not just to those who actively argued for the maintenance or abolition of the death penalty, but to all persons who believed in maintaining or eliminating it.
} 
sentences, executions, canceled executions, partial legislative modifications, and relevant cultural metamorphoses. Some of these developments probably did as much to facilitate abolition as did people's theoretical assessment of the death penalty. ${ }^{2}$ Accordingly, before examining the literature on actual capital-punishment debates and presenting the argument of this thesis in detail, we will consider a few important death-penalty-related developments unfolding during the period of study. This will both provide historical context for the rest of the thesis and create an opportunity to consider the Canadian capital-punishment literature that does not centre upon debates.

And perhaps we can gain the best appreciation of these developments by thinking about Santa Claus.

\section{Historical Context: Execution, Commutation, and Christmastime Robberies}

Something had gotten into Santa Claus on that Friday morning. Montreal being a large city, his slate of gifts for the approaching holiday would undoubtedly cost a goodly sum, so perhaps a bank was a logical building for him to be entering. But Père Noël had not come to the Canadian Imperial Bank of Commerce to draw from his savings account; he and his two colleagues had decided that December 14, 1962, was a good day for a robbery. Santa brandished his authority through the machine gun in his hands; comrades one and two bore their own firearms.

Whatever the powers of the red-suited robber, the trio could not prevent the

\footnotetext{
${ }^{2}$ See especially Carolyn Strange, "The Lottery of Death: Capital Punishment, 1867-1976," Manitoba Law Journal 23, no. 3 (January 1996): 599-600, 617-618. Part of Strange's argument will be discussed later in the chapter.
} 
bank's alarm signal from reaching the police. Within several minutes, officers Denis Brabant and Claude Marineau drove up to investigate the trouble. However, the lawmen immediately found that their adversaries could shoot. Both constables were hit, though at least one did not die immediately. Such would not do for Santa, who approached the fallen cops and spent more bullets on at least one of them. Then Father Christmas "nonchalantly walked back to the car," as one onlooker put it.

Santa and one partner sped off, carrying a take of roughly $\$ 140,000$. The car, a weapon, and the Santa costume turned up quickly, but the robbers remained at large, the targets of "the biggest manhunt in the area's recent history." Investigators eventually ran down their underworld quarry. By January 14, 1963, the press could report that the authorities had three key individuals in custody: Georges Marcotte, Jean-Paul Fournel, and Jules Reeves. ${ }^{3}$

All three soon found themselves charged with capital murder. Still, the Crown's primary target would be Santa's imposter. But which of the three was he? The full-body disguise had proved sufficiently successful to prevent any of the available eyewitnesses

${ }^{3}$ For the quote in the first paragraph on this page, see Al Palmer and Paul Dubois, "'Santa' Bandit Team Kills Two for Less Than $\$ 2,000$ in Loot," Montreal Gazette, December 15, 1962, p. 1-2; for the quote in the second paragraph, see Al Palmer, "Another Man Arrested," Montreal Gazette, January 14, 1963, p. 1; for the other details described above, see also Globe and Mail, "Gang Leader in Santa Claus Outfit Kills 2 Policemen at Montreal Bank," December 15, 1962, p. 1-2; Al Palmer, "2,000 Police Join Manhunt; \$25,000 Price on 3 Killers," Montreal Gazette, December 17, 1962, p. 1-2; Al Palmer, "Police Continue Search for Killers," Montreal Gazette, December 18, 1962, p. 1; Paul Dubois and Clayton Sinclair, "Police Near End of 'Santa' Mob Trail with Arrest of 3 Suspects," Montreal Gazette, January 15, 1963, p. 1, 4; Canadian Press, "3 Men Responsible in 2 Santa Killings, Coroner's Jury Rules," Globe and Mail, January 19, 1963, p. 1; Leon Levinson, "Marcotte Quoted: 'I Killed Them,"' Montreal Gazette, February 20, 1963, p. 3; Canadian Press, "Talkative Santa Described to Court," Globe and Mail, February 26, 1963, p. 27; Leon Levinson, "Marcotte Is Guilty of Santa Slaying; Execution May 31," Montreal Gazette, March 2, 1963, p. 1-2; Leopold Lizotte, “'Santa' Bandit Paints Time Away in Jail," Toronto Daily Star, July 14, 1964, p. 7. 
from convincingly identifying its occupant. Nevertheless, on February 18, 1963, Georges Marcotte entered the dock in a courtroom set to deal with the murder of Claude Marineau. The Crown was ready to make its case; the court would learn from Fournel that the privilege of starring as St. Nick had fallen to Marcotte. Fournel's testimony got the prosecution the capital-murder conviction it wanted, and Marcotte received a sentence of death. Appeals brought the case before both the Quebec Court of Appeal and the Supreme Court of Canada, but both let the conviction stand. ${ }^{4}$

However, the march toward execution led through one more way station. As happened prior to the implementation of any death sentence handed down under the criminal code, the federal cabinet, provided by the Department of Justice with information on the case, was to consider the conviction and decide whether to cancel the execution in favour of a prison sentence. Such a decision would be possible because of the royal prerogative of mercy, upon which cabinet held authority to act in such cases. ${ }^{5}$

Cabinet decisions against execution had become rather frequent in the past several years, and the Liberal government of Lester B. Pearson had difficulty making up its mind — or, more correctly, had difficulty keeping its mind made up in the face of shifting developments. Marcotte was to depart from this life on May 29, 1964, and on May 21

\footnotetext{
${ }^{4}$ See Al Palmer and Paul Dubois, "Crown May Press for Speedy Trial for the 'Santa' Trio," Montreal Gazette, January 19, 1963, p. 1, 4; Leon Levinson, "Georges Marcotte's Murder Trial Opens," Montreal Gazette, February 19, 1963, p. 17; Leon Levinson, "Marcotte Is Guilty of Santa Slaying; Execution May 31," Montreal Gazette, March 2, 1963, p. 1-2; Canadian Press, "Talkative Santa Described to Court," Globe and Mail, February 26, 1963, p. 27; Canadian Press, "Santa Claus Killer Guilty, To Hang May 31," Globe and Mail, March 2, 1963, p. 2; Canadian Press, "Due to Hang Today, Santa Claus Bandit Given Stay to July 3," Globe and Mail, May 29, 1964, p. 1; Leopold Lizotte, "'Santa' Bandit Paints Time Away in Jail," Toronto Daily Star, July 14, 1964, p. 7.

${ }^{5}$ See Strange, "Lottery of Death," 597-599; see also Kenneth L. Avio, "The Quality of Mercy: Exercise of the Royal Prerogative in Canada," Canadian Public Policy 13, no. 3 (1987): 366-368.
} 
cabinet deemed him not to be a suitable candidate for clemency. But less than a day in advance of zero hour, a Quebec judge added five weeks to Marcotte's life span, shifting his hanging date to ensure that Marcotte could provide evidence if need be during Fournel's looming murder trial. ${ }^{6}$ As the new execution date of July 3 approached, further developments placed the situation back in cabinet's lap. Marcotte's lawyer Yves Mayrand had discovered another eyewitness to the crime, one whose evidence had not been made available to Marcotte's jury. Mayrand now claimed that the witness's recollections gave grounds to think that Marineau's fatal wounds may have resulted from bullets fired not by Santa, but by one of his partners. Had Marcotte then been unjustly convicted? Mayrand appealed for a delay in Marcotte's punishment. After dismissing the idea on the morning of July 2 , government leaders decided later that day to give Marcotte an additional week. Several days later, in an effort to settle evidentiary issues once and for all, cabinet arranged for the Quebec Court of Appeal to take up the Marcotte case again to examine additional claims of fact. Marcotte would now live until September $25^{7}$

${ }^{6}$ See Library and Archives Canada (hereafter LAC), RG2, Privy Council Office, Series A-5-a, Volume 6264, Cabinet Minutes, No. 48-64, May 21, 1964, p. 2-3; RG2, Privy Council Office, Series A-5-a, Volume 6265, Cabinet Minutes, No. 60-64, June 25, 1964, p. 2. On the rapid rise in commutations that had occurred since 1957, see Strange, "Lottery of Death," 612, 617-618. Note that I located and consulted the Cabinet Minutes cited in this thesis by searching the digital archive of Cabinet Conclusions on the Web site of Library and Archives Canada and viewing the digitized images of these documents. The URL of the search page is http://www.collectionscanada.ca/archivianet/conclusions/001039-100.01-e.html. Although I do not include this URL with any of the other citations of Cabinet Minutes in this thesis, all were consulted in this digital form.

${ }^{9}$ See LAC RG2, Privy Council Office, Series A-5-a, Volume 6264, Cabinet Minutes, No. 48-64, May 21, 1964, p. 2-3; Volume 6265, Cabinet Minutes, No. 60-64, June 25, 1964, p. 2; Volume 6265, Cabinet Minutes, No. 62-64, July 2, 1964, p. 11; Volume 6265, Cabinet Minutes, No. 63-64, July 3, 1964 , p. 2-5; Volume 6265, Cabinet Minutes, No. 65-64, July 7, 1964, p. 2-3; see also Canadian Press, "Due to Hang Today, Santa Claus Bandit Given Stay to July 3," Globe and Mail, May 29, 1964, p. 1; Canadian Press, "New Facts Claimed in Santa Claus Case," Globe and Mail, July 2, 1964, p. 5; Edwin Bolwell, "Stay 
The court ruled that the guilty verdict would stand. The tenacious Mayrand, however, refused to quit. The Quebec Superior Court ruled that no channel existed for appeal to the Supreme Court of Canada following the unusual court proceeding that had just been completed, but cabinet took the contrary view. Once more, therefore, Mayrand presented arguments on Marcotte's behalf for the assessment of the top court. However, he again failed to persuade the Supremes that anything was amiss in Marcotte's conviction, and Santa remained under the death sentence. With the second anniversary of the robbery approaching, Marcotte was to die on December $4 .^{8}$

Mayrand, of course, was not done. On December 2, he revealed to the press and to cabinet that Fournel had contacted him by mail several months earlier with the claim that Marcotte would find himself off the hook if certain information in Fournel's possession were known - information available for a monetary price. Whatever the merits of the supposed new facts, the offer cast Fournel's integrity, and hence his pivotal evidence in the initial trial, in a rather poor light. Accordingly, Mayrand urged cabinet to give up the plan to execute Marcotte. Apart from Fournel's testimony, how could anyone remain sure that Marcotte and Santa were one and the same? Cabinet, aware of

of Execution Won By Santa Claus Killer," Globe and Mail, July 3, 1964, p. 1-2; Toronto Daily Star, "Santa Bandit Hanging Delayed," July 3, 1964, night edition, p. 1-2; Ottawa Bureau of The Globe and Mail, "New Reprieve Is Given Santa Claus Slayer," Globe and Mail, July 8, 1964, p. 1; Canadian Press, "Marcotte Given Execution Stay for New Appeal," Globe and Mail, September 24, 1964, p. 1.

${ }^{8}$ See LAC, RG2, Privy Council Office, Series A-5-a, Volume 6265, Cabinet Minutes, No. 91-64, September 22, 1964, p. 2; Cabinet Minutes, No. 115-64, November 26, 1964, p. 2-3; see also Canadian Press, "Witness' Story Alters Nothing, Court Rules," Globe and Mail, September 18, 1964, p. 2; Leon Levinson, "Marcotte Stay Fails Here, Counsel Speeds to Ottawa," Montreal Gazette, September 23, 1964, p. 3; Canadian Press, "Marcotte Given Execution Stay for New Appeal," Globe and Mail, September 24, 1964, p. 1; Canadian Press, "Judgment Reserved in Marcotte Appeal," Globe and Mail, November 19, 1964, p. 8; Canadian Press, "2 Killers Due to Hang Unless Cabinet Acts," Globe and Mail, November 25, 1964 , p. 4. 
additional evidence against Marcotte not produced at trial, was skeptical of attempts to question his guilt, but events in recent years had demonstrated how powerfully allegations of wrongful execution could grip the public imagination. Midway through the afternoon of December 2, the Solicitor General had indicated that Marcotte would indeed die, but in light of Mayrand's new move, cabinet entertained second thoughts that evening, agreeing to decide for real the next morning. On December 3, Pearson and his ministers chose to send the executioner home, and to jail Marcotte for life. ${ }^{9}$

The Marcotte affair is a fascinating tale in its own right. But it also intersects with several pivotal developments surrounding the administration of, legislation concerning, and attitudes toward capital punishment in Canada during this period. Accordingly, it provides a useful starting point from which to describe the context in which the debate took place. First of all, the Marcotte case illustrates the tenuous beginnings of the era in which the country would no longer put convicts to death. He actually committed his crime three days after the Canadian state performed what turned out to be its last judicial execution, which occurred on December 11, 1962, when Ronald Turpin and Arthur Lucas were hanged in Toronto. At the time, however, nobody knew, even if some may have suspected, that this two-man execution would mark the end. ${ }^{10}$ Marcotte himself came within a few hours of swinging, and courts continued to deliver death sentences into the

${ }^{9}$ See LAC, RG2, Privy Council Office, Series A-5-a, Volume 6265, Cabinet Minutes, No. 119-64, December 2, 1964, p. 2-3; Cabinet Minutes, No. 120-64, December 3, 1964, p. 2-6; see Ottawa Bureau of The Globe and Mail, "New Evidence Cited, Decision Is Reversed," Globe and Mail, December 4, 1964, p. $1-2$.

${ }^{10}$ On Lucas and Turpin, see Globe and Mail, "2 Killers Hanged; Pickets, Police Close to Clash," December 11, 1962, final edition, p. 1-2, and Carolyn Strange, "The Half-Life of the Death Penalty: Public Memory in Australia and Canada," Australian Canadian Studies 19, no. 2 (2001): 90-93. 
mid-1970s. ${ }^{11}$ At least officially, the offenders so sentenced avoided execution only because of a cabinet decision in each case to place the convict behind walls rather than under a coffin lid. ${ }^{12}$ But allowing Marcotte to avoid death probably strengthened future convicts' chances of receiving mercy as well. Abolitionists certainly tried to argue so, claiming that the death penalty "effectively was abolished" through the Marcotte affair. ${ }^{13}$ As one man asked, "[W]hen you've commuted Marcotte, who [sic] can you hang?"14 The Marcotte case highlights the uncertainty involved in Canada's ambiguous drift away from the actual practice of executing murderers.

If the era of death-penalty implementation ended even before the Marcotte shooting occurred, the most sustained struggle over death-penalty legislation still loomed ahead. Granting clemency to Marcotte injected new life into the issue of legislative abolition. When informing the press that Marcotte would live, federal Justice Minister Guy Favreau also gave notice that before long parliamentarians would receive a chance simply to eliminate death sentencing from the nation's criminal-law regime, should they

\footnotetext{
${ }^{11}$ See Strange, "Lottery of Death," 618; see Canada, Ministry of the Solicitor General, Questions and Answers Relating to the Capital Punishment Issue (Ottawa: 1976), Question No. 40.

${ }^{12}$ See LAC, RG2, Privy Council Office, Series A-5-a, Volume 6265, Cabinet Minutes, No. 120-64, December 3, 1964, p. 2, 5-6; see House of Commons Debates (6 May 1965), 982; (13 October 1970), 54; (26 January 1973), 688 (Warren Allmand, MP - Liberal, Notre-Dame-de-Grâce, QC); (2 July 1975), 7163. Note that the Cabinet Minutes cited in this footnote suggest a partial discrepancy between the official reality and the actual dynamics of this decision-making in the mid-1960s - see also Canadian Press, "On Death Row: Nine Men Await Parliament's Word on Hanging," Toronto Daily Star, January 7, 1965, night edition, p. 1 . I have not determined to what extent the same dynamics may or may not have persisted over the next decade.

${ }^{13}$ Editorial, Globe and Mail, July 20, 1965, p. 6. See also LAC, RG2, Privy Council Office, Series A-5-a, Volume 6265, Cabinet Minutes, No. 63-64, July 3, 1964, p. 4.

${ }_{14}^{14}$ "Mr. Fairweather," quoted in Norman Webster, "A Life and Death Debate in the Commons," Globe and Mail, March 21, 1966, p. 7. The "Mr. Fairweather" referred to was probably abolitionist MP Gordon Fairweather.
} 
so desire. ${ }^{15}$ To be sure, legislative change had already begun. A federal joint

parliamentary committee giving extensive consideration to capital punishment between

1954 and 1956 had called for the death penalty to remain in force. ${ }^{16}$ But private

members' bills allowed the House of Commons to debate abolition briefly in 1958 and

1959 , and, noting the public's strong interest in the matter, the Conservative Diefenbaker

administration allowed the issue to dominate two days of parliamentary debate in $1960 .{ }^{17}$

Actual change came only in 1961 . Until this point, to hear a verdict of guilt on a murder

charge was to know that a death sentence was coming to the man in the dock. ${ }^{18}$ Now a

government bill ended death sentencing for what the bill labeled "non-capital" murders

— those murders not adjudged "planned and deliberate," not occurring in conjunction

with certain other specified felonies, and not involving the killing of a member of a prison

staff or police force. Thus, the legislation sought to prevent "impulsive" murders from

leading toward the gallows but also attempted to ensure that certain killings, including

such murders as those committed by Marcotte, remained subject to the death penalty. ${ }^{19}$

\footnotetext{
${ }^{15}$ See Ottawa Bureau of The Globe and Mail, "New Evidence Cited, Decision Is Reversed," Globe and Mail, December 4, 1964, p. 1-2; see also LAC, RG2, Privy Council Office, Series A-5-a, Volume 6265, Cabinet Minutes, No. 120-64, December 3, 1964, p. 2-6.

${ }^{16}$ See Carolyn Strange, "The Undercurrents of Penal Culture: Punishment of the Body in MidTwentieth-Century Canada,"Law and History Review 19, no. 2 (2001): 345, 350-351, 353-354, 364-365.

${ }^{17}$ See House of Commons Debates (30 May 1958), 711-718; (1 August 1958), 2977-2983; (24 March 1959), 2198-2204; (19 June 1959), 4960-4965; (18 February 1960), 1187-1223, and (25 February 1960), 1441-1474; see LAC, RG2, Privy Council Office, Series A-5-a, Volume 2746, Cabinet Conclusions, No. 15-60, January 28, 1960, p. 3; Cabinet Conclusions, No. 18-60, February 2, 1960, p. 2-3; Cabinet Conclusions, No. 24-60, February 12, 1960, p. 3; Cabinet Conclusions, No. 26-60, February 18, 1960, p. 6. ${ }^{18}$ See Avio, "Exercise of the Royal Prerogative," 367, 374 n. 8.

${ }^{19}$ This is a somewhat simplified description of the bill's provisions; for more precise information, see An Act to amend the Criminal Code (Capital Murder), S.C. 1960-61, c. 44, and Guy Favreau, Capital Punishment: Material Relating to Its Purpose and Value (Ottawa: Queen's Printer, 1965), "Foreword," 5, 66-68. See also Strange, "Lottery of Death," 617. The reference to "impulsive" murder comes not from the statute, but from House of Commons Debates (23 May 1961), 5224 (E.D. Fulton, MP - Progressive Conservative, Kamloops, BC).
} 
The legislative stakes rose to new heights in 1966 when Parliament extensively debated a resolution advocating full abolition, eventually rejecting it by a free vote of $143-112 .^{20}$ The Pearson government responded with legislation in 1967 under which only the murder of an on-duty policeman or prison guard would elicit a death sentence, with capital punishment otherwise being retired experimentally for five years. This time a free vote provided the measure with a 105-70 margin of affirmation. ${ }^{21}$ After a lengthy parliamentary debate in 1973, the Trudeau administration re-instituted essentially the same arrangements for a second five-year term..$^{22}$ Only in 1976 did Parliament choose to eliminate the death penalty for those like Marcotte who killed police officers. The government legislation instituting a death-penalty-free version of the criminal code barely passed third reading in the House of Commons, with a final vote tally of $130-124 .^{23}$

But perhaps the Marcotte case intersects most poignantly with the history of the commutation of capital sentences. Scholars have been bringing this history to light of late: many of the more recent historical studies on the death penalty in Canada focus on practices and mentalities related to the decision whether to cancel or confirm particular

\footnotetext{
${ }^{20}$ Journals of the House of Commons of Canada, $1^{\text {st }}$ Session, $27^{\text {th }}$ Parliament, Volume 113, No. 56 (5 April 1966); on this and the rest of this paragraph, see also Avio, "Exercise of the Royal Prerogative," 366; Strange, "Lottery of Death," 617-619; David B. Chandler, Capital Punishment in Canada: A Sociological Study of Repressive Law (Toronto: McClelland and Stewart Limited, 1976), 14, 19.

${ }^{21}$ This was the vote total on third reading - Journals of the House of Commons of Canada, $2^{\text {nd }}$ Session, 27 ${ }^{\text {th }}$ Parliament, Volume 114, No. 91 (30 November 1967); see also An Act to amend the Criminal Code, S.C. 1967-68, c. 15.

${ }^{22}$ Journals of the House of Commons of Canada, $1^{\text {st }}$ Session, $29^{\text {th }}$ Parliament, Volume 119, No. 156 (24 October 1973); see An Act to amend the Criminal Code, S.C. 1973-74, c. 38.

${ }^{23}$ See Journals of the House of Commons of Canada, $1^{\text {s }}$ Session, $30^{\text {th }}$ Parliament, Volume 121, No. 341 (14 July 1976); see An Act to amend the Criminal Code in relation to the punishment for murder and certain other serious offences, S.C. 1974-75-76, c. 105.
} 
death sentences. ${ }^{24}$ Examining commutation decisions sheds light on various facets of past Canadian society. Not surprisingly, the royal prerogative of mercy created opportunities for the pursuit of political objectives. For instance, historians have suggested that a government's desire to preserve public support for its own administration or to promote the rule of the fledgling Canadian state in territories formerly dominated by aboriginal peoples sometimes provided important motivation in such decision-making. ${ }^{25}$ The extension or withholding of executive clemency also reflected social cleavages within Canada: statistically speaking, the strength of a convict's candidacy for clemency resulted to at least some degree from his or her ethnicity, race, and gender. ${ }^{26}$ Features of Canada's cultural past also come into clearer focus. Not only did the social categories within which a given convict fell affect his chances of actually receiving clemency, but preconceptions about racial distinctions, ethnic character traits, gender makeup, and class propensities helped to shape the way Canadians thought about whether he should be granted clemency. ${ }^{27}$ In addition, commutation practices and citizens' interpretations of them

\footnotetext{
${ }^{24} \mathrm{My}$ language here is admittedly close to that of a letter writer who referred in a different context to "[t]he present clamor whether to confirm or abolish the death penalty" (B.A. Diekman, letter to the editor, Globe and Mail, March 3, 1976, p. 6) and of an MP who referred to "every capital murder case that comes before the cabinet for either confirmation of the death sentence or for commutation" (House of Commons Debates [14 November 1967], 4281 [A.D. Alkenbrack, MP - Progressive Conservative, Prince Edward-Lennox, ON]).

${ }^{25}$ See Strange, "Lottery of Death," especially 596, 602-603, 606-607; see Tom Mitchell, "'Blood with the Taint of Cain': Immigrant Labouring Children, Manitoba Politics, and the Execution of Emily Hilda Blake," Joumal of Canadian Studies 28, no. 4 (1993-4): 49-50, 63-67; see also Jonathan Swainger, "A Distant Edge of Authority: Capital Punishment and the Prerogative of Mercy in British Columbia, 18721880," in Essays in the History of Canadian Law, Volume VI: British Columbia and the Yukon, ed. Hamar Foster and John McLaren (Toronto: University of Toronto Press, 1995), especially 215, 225-226, 229. 595,614

${ }^{26}$ See Avio, "Exercise of the Royal Prerogative," 366-379; see also Strange, "Lottery of Death,"

${ }^{27}$ See Tina Loo, "Savage Mercy: Native Culture and the Modification of Capital Punishment in Nineteenth-Century British Columbia," in Qualities of Mercy: Justice, Punishment, and Discretion, ed. Carolyn Strange (Vancouver: UBC Press, 1996), 109, 112, 118-125; see Kimberley White-Mair, "Negotiating Responsibility: Representations of Criminality and Mind-State in Canadian Law, Medicine
} 
emerged in part out of mentalities flavoured by the values and myths with which

Canadians associated their legal system and government traditions. ${ }^{28}$

Investigating the use of the royal prerogative of mercy does more than simply improve our understanding of how capital punishment was implemented. Historian Carolyn Strange, perhaps the most important interpreter of Canada's use of the death penalty, suggests that the history of commutation stands at the heart of the story of the abolition of capital punishment in this country. Canadians, like their forebears and contemporaries in other Western societies, had always thought that some offenders for whom the law required a death sentence should not in fact suffer execution. This belief carved out a space for the provision of clemency by executive government authorities. ${ }^{29}$ Strange suggests that in the late nineteenth and early twentieth centuries, for example, commutation practices helped to ensure that capital punishment survived in Canada. The theoretical legitimacy of such practices rested on the idea that, at least in exceptional cases, government leaders' situational judgment could provide a more just decision about punishment than could a more rigidly defined legal process, such as that of the courts.

and Society, 1920-1950" (Ph.D. Thesis, University of Toronto, 2001 - Ottawa: National Library of Canada, [2002]), i-iii, 4-6, 8-10, 12, 15-17, 110-112, 159-161, 250-254, http://www.collectionscanada.ca/obj/s4/f2/dsk3/ftp04/NQ63613.pdf; see also Carolyn Strange, "Discretionary Justice: Political Culture and the Death Penalty in New South Wales and Ontario, 18901920," in Qualities of Mercy: Justice, Punishment, and Discretion, ed. Carolyn Strange (Vancouver: UBC Press, 1996), 136-139. 134-137.

${ }^{28}$ See Loo, "Savage Mercy," 108-109, 112-113, 115; Strange, "Discretionary Justice," especially

${ }^{29}$ See Strange, "Lottery of Death," 618; see also Stuart Banner, The Death Penalty: An American History (Cambridge, MA: Harvard University Press, 2002), 54-55, 245, 291-292; see Strange, "Discretionary Justice"; see Carolyn Strange, "Introduction," in Qualities of Mercy: Justice, Punishment, and Discretion, ed. Carolyn Strange (Vancouver: UBC Press, 1996), 4-10, 14-16; see V.A.C. Gatrell, The Hanging Tree: Execution and the English People, 1770-1868 (Oxford, UK: Oxford University Press, 1994), 200-204. 
Whether or not most Canadians actually believed this, the system remained tenable because the public as a whole believed that execution was more appropriate in some instances of murder than in others, and because cabinet could extend clemency to those whose execution would elicit an uncomfortable degree of popular opposition. ${ }^{30}$ However, Strange shows that post-World War II Canadians held greater esteem for consistent, spelled-out methods of completing tasks and reaching decisions - for what we might call "procedural rationality." structured by transparent, generalizable methods, now ran too strongly against the cultural grain, as was reflected in increasing complaints, from both the retentionist and abolitionist sides of the aisle, about cabinet's handling of this task. This attitudinal shift served as a primary catalyst for abolition, with government leaders ending death sentencing due to the difficulty of handling such sentences in a manner that critics would all consider appropriate. ${ }^{32}$

The Marcotte affair reveals hints of this esteem for procedural rationality, and it also illustrates the prevalence of worries about wrongful execution. Both of these factors

\footnotetext{
${ }^{30}$ See Strange, "Discretionary Justice," especially 136-139, 158-161.

${ }^{31}$ The term "procedural rationality" appears in Charles Taylor, Sources of the Self: The Making of the Modern Identity (Cambridge, Massachusetts: Harvard University Press, 1989), 245. I use it not to point to Taylor's discussion, but simply as a shorthand term to evoke both the procedural and rationalizing facets of what Strange is describing in her references to "rationality, objectivity, and scientific certainty" and "procedural ideals" - see Strange, "Undercurrents," 349, and also 353-365, 383-384; see also Strange, "Lottery of Death," 597, 599-600, 617-619.

${ }^{32}$ See Strange, "Lottery of Death," 597, 599-600, 617-619; see Strange, "Discretionary Justice," 131; see also Strange, "Undercurrents," 349, 353-365, 383-384. It should be noted that Strange portrays "procedural values" as helping to facilitate retentionism, although of a less-than-fully-convinced variety, in the context of the mid-1950s joint parliamentary committee - see Strange, "Undercurrents," 349-350, 354$355,365,375$. However, her article "Undercurrents" does reveal the anti-death-penalty potential of these "procedural values," and her article "The Lottery of Death" seems to show that this same general esteem for procedural rationality eventually ended up exerting an anti-capital-punishment effect.
} 
made decision-making about clemency increasingly onerous. As they assessed their options concerning Marcotte, cabinet members discussed whether either a lethal or a carceral punishment for Marcotte would align intelligibly with current legal principles and with recent or upcoming commutation decisions conceming other killers. ${ }^{33}$

Predictably, not all observers thought that cabinet was proceeding sensibly. Upon learning of Marcotte's final deliverance from the noose, the Montreal Gazette spoke bluntly: "For some years now hanging in Canada has been like a game of Russian roulette. There is a remote chance that the murderer may go to his death, but it is only one chance in many. Whatever this system may be called, it has ceased to be orderly justice." Either legislative abolition or the execution of convicts as specified by the law and judiciary remained a better option than more of the status quo, argued the editorialist. ${ }^{34}$

More importantly, the Marcotte case highlighted the potential for continued nagging doubts about a given murder conviction, whether among politicians or the broader public. ${ }^{35}$ For example, when Mayrand pointed to supposedly neglected and possibly exculpatory evidence just before Marcotte's execution day in early July, certain MPs, including at least one retentionist, began to lobby against putting the convict to

\footnotetext{
${ }^{33}$ See LAC, RG2, Privy Council Office, Series A-5-a, Volume 6264, Cabinet Minutes, No. 48-64, May 21, 1964, p. 2-3; Volume 6265, Cabinet Minutes, No. 60-64, June 25, 1964, p. 2; Volume 6265, Cabinet Minutes, No. 63-64, July 3, 1964, p. 4; Volume 6265, Cabinet Minutes, No. 115-64, November 26, 1964, p. 2-3; Volume 6265, Cabinet Minutes, No. 120-64, December 3, 1964, p. 2-6.

${ }^{34}$ Editorial, Montreal Gazette, December 7, 1964, p. 8.

${ }^{35}$ For one former Conservative cabinet member's reference to such "lingering doubt," possibly with regard to cases during his own time in cabinet, see House of Commons Debates (5 April 1966), 3865 (Gordon Churchill, MP - Progressive Conservative, Winnipeg South Centre, MB); see also (10 November 1967), 4162 (Gordon Churchill, MP).
} 
death, at least in the immediate future. ${ }^{36}$ Also, cabinet gave the green light for Marcotte's commutation just one day before Canadians learned of the findings of a commission of inquiry concerning the famous trial of Wilbert Coffin in Quebec in the mid-1950s. Having gone to the gallows for murder after a controversial trial, Coffin became the subject of an author's attempt at a book-length exposé entitled I Accuse the Assassins of Coffin. The book's bold assertions stung badly enough to induce the Quebec authorities to subject the matter to reassessment by a royal commission. The single commissioner ended up reporting that much of the book had gone well wide of the mark. But the public-relations difficulties that the volume had produced for various authorities still stood as a reminder of the damage that could result from suspicion about a conviction. ${ }^{37}$ Indeed, cabinet worried that Marcotte might end up being perceived as Coffin II. Marcotte's guilt had seemed more certain than Coffin's, but Marcotte's lawyer could nonetheless raise continuing questions about it, to a nearly comical degree. ${ }^{38}$ Such dynamics could make cabinet decision-making about commutation a thoroughly

\footnotetext{
${ }^{36}$ See Toronto Daily Star, "Santa Bandit Hanging Delayed," July 3, 1964, night edition, p. 1-2; see House of Commons Debates (2 July 1964), 4927-4930 (statements of Rémi Paul, MP [Progressive Conservative - Berthier-Maskinongé-Delanaudière] and Paul Martineau, MP [Progressive Conservative Pontiac-Témiscamingue]). On Paul's otherwise retentionist stance, see House of Commons Debates (18 February 1960), 1217-1218 (Rémi Paul, MP); (23 May 1961), 5273-5275 (Rémi Paul, MP); House of Commons Debates (26 January 1973), 701-702 (C.-A. Gauthier, MP - Social Credit, Roberval, QC); on Martineau's retentionist stance in at least 1960 and 1961, see House of Commons Debates (25 February 1960), 1449-1450 (Paul Martineau, MP); (23 May 1961), 5248, 5256-5259 (Paul Martineau, MP).

${ }^{37}$ See Toronto Daily Star, "Quebec Judge to Probe Coffin's Trial and Execution," January 9, 1964, night edition, p. 1, 5; Thomas Sloan, "Quebec Orders Full Investigation of Coffin Case," Globe and Mail, January 9, 1964, final edition, p. 1; Gordon Pape, "Coffin Defence Claims Judged 'False, Unjust,"” Montreal Gazette, December 5, 1964, p. 1-2; Robert Duffy, "Coffin Justly Hanged, Quebec Inquiry Rules," Globe and Mail, December 5, 1964, p. 1; Jacques Hébert, I Accuse the Assassins of Coffin (Montreal: Les Éditions du Jour, 1964) (originally published in French in 1963).

${ }^{38}$ See LAC, RG2, Privy Council Office, Series A-5-a, Volume 6265, Cabinet Minutes, No. 65-64, July 7, 1964, p. 3; Cabinet Minutes, No. 115-64, November 26, 1964, p. 2-3; Cabinet Minutes, No. 119-64, December 2, 1964, p. 3; Cabinet Minutes, No. 120-64, December 3, 1964, p. 2-3.
} 
frustrating activity.

Commutation would remain a prominent topic of discussion in the capitalpunishment debate during the following decade, with the government's approach to it generally being cast in an unfavourable light, and frequently being loudly denounced. ${ }^{39}$ As Strange has suggested, the altered attitude toward this practice may well have been the most important factor contributing to the abolition of death sentencing. Some individuals' opposition to commutation probably went hand-in-hand with their disapproval of authorities' parole-granting practices; in any case, many citizens considered parole or other types of leave from penitentiaries to be too readily available to serious offenders ${ }^{40}$ Here too Marcotte enters the picture. On the same day on which the Pearson government canceled his execution, it also finalized an order-in-council specifying that henceforward a capital convict spared from execution could not receive parole until cabinet assented. ${ }^{41}$ But the move would not give the authorities long-term freedom from rebukes concerning their real or supposed parole policies concerning murderers. Accordingly, the periods of incarceration serving as prerequisites for the acquisition of parole would become lengthier for some types of killers in the 1970s, as the

\footnotetext{
${ }^{39}$ For just three examples of criticism, see House of Commons Debates (9 November 1967), 4086 (Eldon Woolliams, MP - Progressive Conservative, Bow River, AB); (14 November 1967), 4281 (A.D. Alkenbrack, MP - Progressive Conservative, Prince Edward-Lennox, ON); (31 January 1973), 841 (L.loyd Crouse, MP - Progressive Conservative, South Shore, NS).

${ }^{40}$ For one example of discontent with parole practices, see Patricia J. Smith, letter to the editor, Toronto Star, February 20, 1975, p. B5. See also House of Commons Debates (13 December 1963), 5841 (Réal Caouette, MP - Ralliement Créditiste, Villeneuve, QC). For a possible example of a connection between discontent with commutation and discontent with parole, see "Horrified," letter to the editor, Toronto Daily Star, December 11, 1964, p. 6.

${ }^{41}$ See LAC, RG2, Privy Council Office, Series A-5-a, Volume 6265, Cabinet Minutes, No. 114-64, November 26, 1964, p. 3; Cabinet Minutes, No. 120-64, December 3, 1964, p. 13; see also Richard Snell, "Now - All-Out Drive To Fire the Hangman," Toronto Daily Star, night edition, December 4, 1964, p. 1, 5.
} 
Trudeau administration sought to address the public dissatisfaction materializing in response to its intention to retire the death penalty. ${ }^{42}$

In sum, the Marcotte affair calls attention to the concrete changes that occurred between the mid-1950s and mid-1970s with respect to execution, commutation, parole, and criminal legislation. Marcotte's story also stands as a reminder that specific events and individual cases lay underneath and did much to create whatever more general trends we may perceive. Nevertheless, "the Santa Claus murderer"43 also surfaced in those aspects of the capital-punishment controversy in which broad ideas and generalized evaluation remained prominent. Marcotte was mentioned a number of times during the loud and long debate occurring in the House of Commons about the merits of the death penalty as a general policy ${ }^{44}-$ a debate that flourished outside Parliament as well. In the end, then, despite the importance of his near-execution and commutation to those deathpenalty-related developments of the 1960 s that involved more than mere debate, his story also points to the penchant that a good number of Canadians displayed for discussing and arguing about the death penalty. While recognizing the significance of the type of

\footnotetext{
${ }^{42}$ See Canada, Ministry of the Solicitor General, Questions and Answers, Questions No. 23 and No. 28; see House of Commons Debates (26 January 1973), 688 (Warren Allmand, MP - Liberal, NotreDame-de-Grâce, QC); (15 June 1976), 14500 (Pierre Trudeau, MP); see An Act to amend the Criminal Code, S.C. 1973-74, c. 38, s. 3; An Act to amend the Criminal Code in relation to the punishment for murder and certain other serious offences, S.C. 1974-75-76, c. 105, ss. 13, 15, 21; see also Strange, "Lottery of Death," 618-619; see also Jeffrey Meyer, "Evaluating the Punitive Turn Thesis: Is Canadian Penal Discourse Officially Exemplifying a Punitive Mentality?" (M.A. Thesis, Carleton University, 2004), 74. ON).

${ }^{43}$ House of Commons Debates (12 April 1965), 292 (Ralph Cowan, MP - Liberal, York-Humber,

${ }^{44}$ At least nineteen speeches in the parliamentary death-penalty debates included a reference to the Marcotte affair. This is not to say that these references to Marcotte all served to convey a direct point concerning the given speaker's perspective on capital punishment in general; in some cases speakers' words about Marcotte occurred in the context of comments about clemency and clemency-related happenings.
} 
developments discussed in the preceding pages, this thesis will devote its attention to debate participants' thought and argument about capital punishment as a general policy.

\section{The Historiography of Death-Penalty Debates}

A preliminary exploration of a few capital-punishment debates in the nineteenth- and twentieth-century Western world might create the impression in some people's minds that abolitionists and retentionists always gravitate toward certain largely unchanging ideas and claims, with those heard in debate in a given country not differing markedly from those used in many nations in the post-Enlightenment West. ${ }^{45}$ Although this may be true at a very broad level, historians have demonstrated that death-penalty debates have actually tended to take on the cultural hues of the time or place in question, in ways that at least sometimes contributed significantly to the outcome of the given debate ${ }^{46}$ In the early decades of the newly independent United States, for instance, Americans evaluated the propriety of the death penalty partly in light of their desire to cultivate the ethos that they believed should animate a republic, as opposed to the way of life embedded in the monarchical system from which they had freed themselves. ${ }^{47}$ In early-nineteenth-century Britain, religious tenets acted as the chief source of sustenance for the pro-capital-

\footnotetext{
${ }^{45}$ For a study which notes how much many death-penalty debates have in common with one another, but which also reveals that the respective ideas influencing capital-punishment-related mentalities at different historical junctures have been far from identical, see Jayne Seagrave, "The Death Penalty: Will Canada or Britain Restore This Punishment?" (M.A. Thesis, University of Ottawa, 1986), 1, 14, 16-27.

${ }^{46}$ See especially Randall McGowen, "History, Culture and the Death Penalty: The British Debates, 1840-70," Historical Reflections/Réflexions Historiques 29, no. 2 (Summer 2003): 230-231, 249, and Strange, "Undercurrents," 382-384. However, for a sense of the remarkable similarities between the rhetoric used in the nineteenth and the twentieth centuries, compare the ideas examined in this thesis with the rest of the above-mentioned article by McGowen.

${ }^{47}$ See Louis Masur, Rites of Execution: Capital Punishment and the Transformation of American Culture, 1776-1865 (New York, NY: Oxford University Press, 1989), 4-6, 50-51, 54-66, 70.
} 
punishment stance. In contrast, between 1840 and 1870, the idea of holding human life in high esteem and of staunchly promoting its preservation had become the foundational cultural value on which both camps in the British debate built their cases, with the retentionists carrying the day, perhaps because of their more effective incorporation of this value into their arguments. ${ }^{48}$ During the late 1800 s and early 1900 s, influential European criminological theorists suggested that the workings of some individuals' biology or the push and pull of the world in which they lived nearly ensured that they would engage in criminal activity, the human species being able to claim only a narrowed share, if any at all, in freedom of will. Such theorists asserted that "social defence," not legal assessment of guilt and desert, provided the appropriate logic to guide penal policies. These ideas helped to support pro-retention attitudes surfacing during a deathpenalty debate in early-twentieth-century France, a debate in which abolition was rejected. ${ }^{49}$ Additional examples abound: debates on the death penalty, despite their similarities, have not escaped the imprint of time and place.

The truth of this claim in the Canadian case comes to light most clearly in studies by Carolyn Strange. By analyzing the discussion occurring in two special parliamentary committees that examined capital punishment in 1937 and 1954-1956, Strange shows that the notion of civility stood as a compelling ideal in the minds of not only abolitionists,

\footnotetext{
${ }^{48}$ McGowen, "History, Culture, and the Death Penalty," 230-233, 237-241, 248-249.

${ }^{49}$ See Robert Nye, "Two Capital Punishment Debates in France: 1908 and 1981," Historical Reflections/ Réflexions Historiques 29, no. 2 (Summer 2003): 217-219, 221; see also David Garland, Punishment and Welfare: A History of Penal Strategies (Aldershot, Hants, England; Brookfield, Vermont: Gower, 1985), 84-93, 98-101, 104-105; Pasquale Pasquino, "Criminology: The Birth of a Special Savoir," trans. Colin Gordon, in The Origins and Growth of Criminology: Essays on Intellectual History, 17601945, ed. Piers Beirne, 131-146 (Aldershot, Hants, England; Brookfield, Vermont: Dartmouth Publishing Company Limited, 1994).
} 
but also retentionists. Indeed, the concept of being civilized provided a rhetorical vehicle through which the committees could legitimize the continued practice of capital punishment. Admittedly, the infliction of bodily suffering or violent harm seemed at odds with civility. However, keeping crime to a minimum, even if by means of occasionally harsh penalties, appeared to be an important part of sustaining the civilized character of Canada. ${ }^{50}$

Moreover, the association of civility with retentionist policy became possible partly through cultural values that specially characterized this particular historical setting. Strange draws attention to the ways in which Canadians' support for capital punishment rested on their perceptions of the nation's position vis-à-vis Great Britain and the United States. Especially prior to World War II, many things British, including hanging as a means of capital punishment, still held a special credibility in the eyes of many Canadians. This was reflected in the 1937 committee's endorsement of execution by hanging rather than by gas or electricity. The latter two instruments could boast of being used for executing convicts in various American states, but such a precedent did not lead to Canadian emulation, perhaps partly because Canadians thought their own society already exemplified civilized ideals better than American life did. As well, members of both the 1937 and the $1954-1956$ committees found the death penalty attractive due to the prospect that American professional criminals might seek to enter the northern nation if capital punishment were not in force. However, time brought certain cultural changes. In

${ }^{50}$ See Strange, "Undercurrents," 345-346, 348-349, 355, 360-361, 364-366, 368-370, 372, 375 , 377-379, 381-385. 
the postwar era, remaining true to the British way mattered a little less to Canadian leaders, but they saw increasingly strong links between being civilized and acting under the guidance of procedural rationality. Procedure and technique created possibilities for using physical punishment while better ensuring that the offender experienced no more than a minimum of pain. Accordingly, the 1950 s committee affirmed the death penalty but now suggested that killers be put to death in the electric chair or the gas chamber rather than on the less reliable gallows (a piece of advice not taken by the government). In sum, Canadians' perceptions of civility and capital punishment resulted partly from their vantage point in space and time. ${ }^{51}$

If Strange has sought to pinpoint the historicity of Canadian perspectives on capital punishment, sociologist David Chandler has taken the opposite approach. In a book written not long before the death penalty was eliminated, Chandler examines public opinion, parliamentary voting, and the relationship of these factors to sociological variables during the Canadian death-penalty controversy in the 1960s and early 1970s. He notes that he is primarily seeking to gain insight into the principles by which many societies operate rather than to understand Canada in particular. Nonetheless, his portrayal of the controversy is important. Among other things, his discussion suggests that the divergent perspectives within the citizenry with respect to a broad issue - the issue of why society possesses law — bore part of the responsibility for the abolitionversus-retention dispute. In the eyes of some Canadians, "expressive" dynamics counted as the signature feature of law. Law "display[ed] the ideals of the culture" and

\footnotetext{
${ }^{51}$ See ibid., 344-346, 349-351, 353-371, 376-378, 381-384.
} 
proclaimed the citizenry to be "unalterably opposed to the violation of certain values."

Others believed that law ought to be "instrumental," seeking simply to minimize those activities that would detract in practical ways from the people's peace and welfare. Expressivists were more likely to deem execution a suitable punishment for murder, since this crime sat near the top of society's list of forbidden acts. In contrast, because studies were by the 1960 s suggesting that murder would occur no less frequently when punishable by death than when punishable by imprisonment, Chandler suggests that abolition tended to win instrumentalists' approval. ${ }^{52}$

\section{Methodology and Argument}

Though Strange and Chandler offer important insights into the mid-twentieth-century debate over the general merits of capital punishment, there is room for this thesis to make a further contribution, partly by examining additional sources, and, more importantly, by interpreting the debate from a different angle. In examining the 1957-1976 period, this study spans the years between the release of the Reports of the Joint Committee of the

${ }^{52}$ See Chandler, Capital Punishment in Canada, especially xvix, xxii-xxiii, 4-6, 11, 24, 27-29, 53, 70 n. 17, 198, 204 n. 48; see also 205-206 n. 53. The quoted phrases are from pages 11 and xxiii, respectively. Note that while the adjectives "expressive" and "instrumental" feature prominently in Chandler's discussion, I am not aware of any appearance of the terms "expressivist" or "instrumentalist" in his book (a Google ${ }^{\mathrm{TM}}$ Book Search of the book revealed none). Furthermore, when employing the term "instrumental" to describe certain Canadians' outlook with respect to the issues that he is discussing, he does not necessarily seem to be suggesting that such citizens were adherents of an overall instrumentalist philosophy in a more technical sense. Instead, he is observing that, based on their utterances concerning capital punishment, their worldview seemed to include a largely "instrumental orientation to law" (p. 24) and penal affairs, however devoted they may or may not have been to instrumentalism in a wider sense. Although I use the terms "instrumentalist" and "instrumentalism" at various points in this thesis, I use them in a sense corresponding to Chandler's discussion - in reference to people's thinking on penal affairs, not in an effort to claim that the persons or perspectives in question would fall within the bounds of philosophical instrumentalism in a more technical sense. 
Senate and House of Commons on Capital and Corporal Punishment and Lotteries in $1956^{53}$ and legislative abolition in 1976. Of any period in Canadian history, these two decades saw by far the most debate on the topic in the House of Commons, and almost certainly the most among the general public. The intention here is to tap into the discussion in both arenas in order to achieve a sense of the overall character of the debate in the public sphere.

Although the parliamentary debates have been examined by more than one scholar, they remain central to understanding the climate of thought in the country at the time. ${ }^{54}$ In one sense, these debates are important because of their representativeness. Hansard contains a very large number of thorough speeches in which MPs expressed a wide range of perspectives, yet in a manner probably intended both to maintain respectability among opinion leaders and to recognize constituents' perspectives. In another sense, the parliamentary debates are important because of their potential uniqueness. As we shall see, polls suggest that public opinion on the issue did not necessarily follow the trajectory from retentionism to abolitionism that legislative changes seemed to mark out, and parliamentary talk thus may not have reflected the public mood perfectly. However, although this thesis seeks to show what shaped the rhetoric of the debate itself rather than to explain directly or fully why capital punishment

\footnotetext{
${ }^{53}$ Canada, Reports of the Joint Committee of the Senate and House of Commons on Capital and Corporal Punishment and Lotteries (Ottawa: Queen's Printer, 1956).

${ }^{54}$ Two of the studies drawing upon the parliamentary debates within this period are Chandler, Capital Punishment in Canada, and Mathieu Bureau, "L'Abolition de la Peine de Mort au Canada: Le Discours Politique et L'Opinion Publique lors des Débats de 1966-1967, 1973 et 1976" (M.A. Thesis, Université de Sherbrooke, 2000 - Ottawa: National Library of Canada, [2002]), http://www.collectionscanada.ca/obj/s4/f2/dsk2/ftp03/MQ61721.pdf.
} 
was actually abolished, Parliament's decision to change the law, after having long been reluctant to do so, remains one of the most obvious historical developments concerning the death penalty. To omit parliamentarians' discussion would thus seem unwise, even if it may have diverged in some respects from that occurring in other public forums.

To capture some of what was said in those other forums, this thesis draws upon letters to the editor published in the Globe and Mail and the Toronto Daily Star. ${ }^{55}$ I am not aware of any study that has used a systematic review of letters to the editor to explore the types of questions addressed in the present thesis. ${ }^{56}$ Although these newspapers published some letters from communities outside Toronto and even outside Ontario, the majority do originate from urban Ontario. To provide a modest counterbalance to this regional concentration, I have examined the letters-to-the-editor section in Quebec City's Le Soleil for five one- or two-month periods, ${ }^{57}$ and I have reviewed death-penalty-related correspondence from constituents that is found in the personal papers of three long-

\footnotetext{
${ }^{55}$ I located letters to the editor by electronically searching the digital archive for each of these newspapers. However, although the full text of the two papers is searchable, the Optical Character Recognition search technology fails to recognize many words within the text when the digitized print quality is poor. As a result, electronic searches failed to capture some of the letters to the editor discussing capital punishment. My sampling technique was to search the portions of the paper coded for opinion/editorial material, using the search terms "punishment" and "penalty." I thereby identified many letters discussing the death penalty, and I also reviewed the letters-to-the-editor page by eye for each issue falling within one week of the date of these initially identified pages. This methodology was used for the period 1957-July 1976. However, the methodology undoubtedly did not bring all letters within this period to light. One anomaly, for example, concerns the period from December 1967 to mid-June 1969, for which my search yielded no letters on the topic in the Toronto Daily Star. The explanation might possibly lie in coding anomalies in the digital archive for a portion of this period. Note that although I have not included the online URL when citing items from these two newspapers, in most cases I did indeed consult the item in question online via the digital archive.

${ }^{56}$ Criminologist C.H.S. Jayewardene drew on newspaper sources in "The Canadian Movement Against the Death Penalty," Canadian Journal of Criminology and Corrections 14 (1972): 366-390. However, he did not discuss the development of ideas in the debate to the same degree that I do.

${ }_{57}$ February 15-March 15, 1960; March 15-April 15, 1966; November 7-December 6, 1967; May 1June 30, 1973; May 1-June 30, 1976. Debate on capital punishment took place in the House of Commons within these periods.
} 
serving MPs - one each from Alberta, Manitoba, and Prince Edward Island. ${ }^{58}$

Additional material from parliamentarians' papers and from other Canadian publications also appears at various points in the discussion. Although some basic Gallup polling results will be noted, this study generally does not attempt to determine the thinking of the population as a whole. Instead, the sources consulted here reflect the views of those interested enough in the issue to express their opinions in writing and send them to the recipients in question. These writers' views may have differed in content or intensity from those of their everyday neighbours, but as in the case of any public issue, the manner in which the controversy was publicly represented and understood stemmed primarily from the input of those citizens who actively participated in public discussion. ${ }^{59}$ At the same time, these participants could not have avoided approaching the issue from a vantage point at least partially reflective of the culture of the citizenry as a whole. Accordingly, the sources examined here provide evidence well suited to the purposes of this study.

This thesis offers a threefold argument concerning the nature of the debate that occurred. First, specific information disseminated and events occurring during this period influenced discussion significantly, providing both empirical and rhetorical ingredients that allowed the debate to unfold in the direction it eventually took. This admittedly

\footnotetext{
${ }^{58}$ The three are Marcel Lambert (Progressive Conservative), who represented Edmonton West from 1957 to 1984; Heath MacQuarrie (Progressive Conservative), who represented the ridings of Queen's and then Hillsborough in Prince Edward Island from 1957 to 1979; and Walter Dinsdale (Progressive Conservative), who represented the ridings of Brandon and then Brandon-Souris in Manitoba from 1951 to 1982. Collections of personal papers of each of these MPs are found in the National Archives of Canada.

${ }^{59}$ For a discussion pointing toward this general type of idea, see James Davison Hunter, Culture Wars: The Struggle to Define America ([New York]: Basic Books, 1991), 52-57, 59-61.
} 
unprofound claim both confirms and clarifies certain aspects of Strange's brief characterization of the debate in the 1960s and 1970s. According to Strange, parliamentarians in the mid-1950s confronted only a modest amount of scholarly research questioning the power of capital punishment to lessen the frequency of murder, and they could thus maintain belief in its deterrent force. By contrast, the accrual of a much more substantial amount of research in the following two decades debunked their assumption more clearly, leaving them without what had been one of their more persuasive reasons for rejecting abolition. ${ }^{60}$ Here Strange gets it right: MPs' speeches and writings reveal that scholarly findings emerging during this period, especially those appearing in the 1970s, did indeed provide pivotal sustenance to the abolitionists' position while impeding the retentionists' arguments, thus greatly facilitating the eventual success of the abolitionist cause in the House of Commons. ${ }^{61}$

However, in referring to the 1967 legislation that temporarily ended death sentencing for most capital murder, Strange states that legislators hoped "to determine whether suspending the death penalty inspired people to commit murder. It did not, and the abolitionists won. ${ }^{.62}$ While probably factually correct, such a statement creates a misleading impression about the attitudes and perceptions surrounding this issue in the last few years preceding abolition. Strange does refer to legislative efforts "to appease law enforcement lobbyists" when abolition occurred in 1976; this phrase hints at the

\footnotetext{
${ }^{60}$ See Strange, "Undercurrents," 378, 381-385.

${ }^{61}$ Strange herself points out one of the pivotal pieces of such research from the early 1970 s - see ibid., 385 n. 102.

${ }^{62}$ Strange, "Lottery of Death," 618.
} 
1970s reality a little more accurately. ${ }^{63}$ Far from being a time of agreeable experiment and ready recognition of the benign effects of dispensing with capital punishment, the 1970s witnessed increasingly plenteous instances of murder, several high-profile debacles in penal administration, and an increasing resistance among the citizenry to the idea of complete abolition. Against a backdrop of disquiet over terrorism and a souring economy, such developments generated forceful expressions of opinion, altered the rhetorical framework within which parliamentarians debated the issue, and moved the government to offset abolition with other crime-suppressing legislative initiatives. ${ }^{64}$ In short, both emerging information and contemporary events contributed to the framework within which Canadians conceived of and argued about the death penalty, and this was as true of the 1970 s as Strange reveals it to have been in preceding years. ${ }^{65}$

Secondly, and more importantly, this thesis will show that moral commitments and claims were essential and powerful ingredients in the debate. ${ }^{66}$ This argument stands

\footnotetext{
${ }^{63}$ Ibid.; see also 619. She also notes elsewhere that "opponents and supporters of abolition lobbied vigorously" in the 1970s - Strange, "Undercurrents," 351.

${ }^{64}$ On terrorism as an ingredient in the situation, see Ezzat A. Fattah, The Canadian Public and the Death Penalty: A Study of a Social Attitude ([Ottawa, ON?], [1976]), 5-6. For one parliamentarian's suggestion that economic struggles were helping to stimulate a capital-punishment-friendly mentality in the nation in the mid-1970s, see House of Commons Debates (5 May 1976), 13217-13218 (David Collenette, MP - Liberal, York East, ON). For brief information on the other legislative initiatives referred to, see House of Commons Debates (3 May 1976), 13099 (Norman Cafik, MP - Liberal, Ontario, ON); (5 May 1973), 13207-13209 (Norman Cafik, MP).

${ }_{65}^{65}$ See, for example, Strange, "Lottery of Death," 612-613, 617-618.

${ }^{66} \mathrm{I}$ use the word "moral" in a very broad sense. For instance, in this thesis "moral" and "ethical" serve as synonyms. I do not use "moral" to describe only those types of normative claims in which debate participants represented a particular stance or action as being universally required, a matter of clear-cut right and wrong for all people everywhere. Instead, "moral" is sometimes also used here in reference to values and claims that are concerned with better and worse more than with right and wrong, that deal with motivation and attitude rather than action, and that have more to do with aspiration than duty. When voicing their views on capital punishment, Canadians in many cases did not specify whether they thought it was truly incumbent upon others to assent to the value judgments they were offering, or whether they were simply voicing their own strong values that could lodge no necessary claim upon others' allegiance. However, debaters' statements frequently carried a sufficiently passionate and convinced tone to signal that
} 
in partial contrast to the accounts offered by Strange and Chandler. Strange suggests that a deepening cultural esteem for procedural rationality in judicial contexts did more to bring about abolition in Canada than did moral commitment, although she does recognize that pro-abolition advocates themselves possessed a good deal of "humanitarian sentiment." ${ }^{, 67}$ Admittedly, Chandler does highlight the importance of moral considerations to retentionists, and he also points out the strong moral commitments and rhetoric of abolitionists. ${ }^{68}$ But his emphasis on the affinity between abolitionism and an instrumental mind-set concerning law makes it easy for readers to obtain the impression, even if technically erroneous, that Chandler believes ethical values held only secondary importance in the overall phenomenon of the gradual shift toward abolition. This impression grows yet stronger as a result of his implicit suggestion that Canadians' perspectives on law will become increasingly instrumentalist with the passage of time. ${ }^{69}$ As it happens, the sources examined for this thesis offer a good deal of evidence that

they considered the issue under discussion to be of a gravity "incomparable" (to use Charles Taylor's term) with evaluations governed by mere taste, and that their views were tied tightly to their foundational understanding of the good and the bad in human affairs. My thinking here about what sorts of thought patterns qualify as "moral" draws upon Charles Taylor's discussion in Sources of the Self (see, for example, $3-4,14-15,19-20,79-80,85-90$ - "incomparable" appears on page 20,88 , for example), although what I have said might not perfectly adhere to the types of ideas he is endorsing. And he is of course not talking about capital-punishment debates. Also, a good deal of the vocabulary I have used in this footnote is used in Taylor's discussion. For comments suggesting, by contrast, that "moral theory" and "ethics" are not synonymous, with "moral theory" pertaining "to questions of justice" and to "rights and duties that everyone ascribes to one another from an inclusive we-perspective," and with "ethics" pertaining to "our own life from the first-person perspective and" to "what is best 'for me' or 'for us' in the long run and all things considered," see Jürgen Habermas, "Are There Postmetaphysical Answers to the Question: What is the 'Good Life'?", in The Future of Human Nature, this essay trans. William Rehg (Cambridge, UK: Polity Press, 2003), 3-4.

${ }^{67}$ See Strange, "Lottery of Death," 599-600, 617-618.

${ }^{68}$ See Chandler, Capital Punishment in Canada, 24, 26-27, 29, 33-34, 35 n. 19, 53, 72-73 n. 35 , $139-140,158,205-206$ n. 53.

${ }^{69}$ See ibid., 4, 24, 27, 53, 125-127, 141, 198-200, 205-206 n. 53; but see also 182. For discussion that might imply that Chandler did not believe that ethical values would make a less important contribution to abolitionist developments than would instrumental thinking, see ibid., 32-33. 
could be cited in support of Strange's and Chandler's accounts. It is especially clear that many Canadians, particularly parliamentarians and other opinion leaders, did indeed discuss capital punishment from an instrumental vantage point. Against the background of Chandler's argument, what stands out is the extent to which both abolitionist and retentionist MPs focused on questions about the practical results of retention or abolition, especially on questions concerning the deterrent dynamics of criminal penalties or the chances of criminal recidivism. ${ }^{70}$ However, as the following chapters will demonstrate, this very characteristic of the debate resulted to a substantial degree from debaters' ethical presuppositions. In addition, debaters continued to augment their "factually" oriented arguments with moral appeals. Furthermore, in some cases instrumentally flavoured thinking helped to endow abolitionists with the confidence to promote a deepened adherence to moral ideals. This thesis does not so much challenge the arguments of Strange and Chandler as complement them, telling the other side of the story — that the death-penalty debate was undergirded by and infused with moral assumptions and claims. $^{71}$

To argue that moral thinking remained prominent in a discussion about whether to kill people is perhaps to state the obvious. Less obvious, if only slightly so, is what the debate suggests about the nature of Canadian moral culture during this period. Here the work of sociologist James Davison Hunter provides a useful starting point. Hunter's

\footnotetext{
${ }^{70}$ Chandler does acknowledge that retentionist MPs did often argue within an instrumental framework - see ibid., 23.

${ }^{71}$ The idea of organizing the argument of this thesis around the role of moral commitments in the debate was stimulated in part by a study on a very different topic, A.B. McKillop, A Disciplined Intelligence: Critical Inquiry and Canadian Thought in the Victorian Era, Carleton Library Series 193 (Montreal \& Kingston: McGill-Queen's University Press, 2001).
} 
book Culture Wars: The Struggle to Define America suggests that the latter portion of the twentieth century saw "orthodox" and "progressive" conceptions of the nature of morality become the preeminent factors creating cultural comradeship or friction between various subsets of the American populace. Those Americans who operate with an "orthodox" cast of mind tend to assume that a phenomenon under moral evaluation possesses its status as a good or bad thing by virtue of the nature of its relationship to a "transcendent," unchanging moral reality, a supreme dimension of good not basically contingent upon the historically fluctuating particulars of human existence. By contrast, those who think about life in accordance with a "progressive" paradigm consider morality to be a way of continually moving toward an optimum human existence, which will be achieved by attaining better understanding of the world in which we find ourselves, by becoming more attuned to the conditions facilitating human vitality, and, in the light of our discoveries, by devising norms by which to live - norms which should improve over time. These two mind-sets generate very different cultures, a phenomenon that becomes particularly visible when citizens step into the public sphere to have their say in decision-making on matters of collective concern. ${ }^{72}$

Both the historical context and the sociological phenomenon discussed by Hunter differ from those pertinent to the death-penalty debate in Canada. Nevertheless, his concepts are helpful and his terms useful (if in a slightly different way than he employs

${ }^{72}$ See Hunter, Culture Wars, 34-57, 60-61, 95, 107-108, 113-114, 117-128. 
them) for articulating the third element of the argument of this thesis. ${ }^{73}$ To wit, the debate illustrates the weakened cultural credibility of transcendently oriented moral thinking in Canada during this period and reveals the important influence, if by no means dominance, that a progressive moral mentality could exercise. The weakened confidence in the former and the modest support commanded by the latter worked in combination to form a sizeable yet circumscribed rhetorical and philosophical zone within which less ideologically assured citizens could argue without feeling that they were putting themselves on the margin of credibility.

Thus, a relatively small but vocal group, largely conservative Christians, defended capital punishment through appeals to the notion of a timeless, metaphysical justice and, more importantly, to divine directives. By contrast, whether out of religious commitment, a principled ethical opposition to coercion and affliction, or a simple uncertainty about the acceptability of retributive punishment, many Canadians believed that only the possible prevention of a tangible, this-worldly "greater evil" could render the infliction of death legitimate. ${ }^{74}$ In line with the public dominance of this latter viewpoint, many retentionists strove to point out tangible advantages in capital punishment. Not surprisingly, many retentionists also gave voice to their sense of the intrinsic moral

\footnotetext{
${ }^{73}$ It should be noted that I first became aware of Hunter's book and the pertinence of the terms "transcendent" and "progressive" to his argument through a Weblog post at GetReligion.org. The post in question may have been Terry Mattingly, "Dang it, there's that question again," June 6, 2006, http://www.getreligion.org/?m=200606\&paged $=4$ (accessed July 31, 2007); in conjunction with this, see Terry Mattingly, "Ten Years of Reporting on a Fault Line," Terry Mattingly on Religion column, http://tmatt.gospelcom.net/column/1998/04/15/ (accessed July 31, 2007).

${ }^{74} \mathrm{~A}$ statement by NDP leader David Lewis expresses the same type of idea and uses the term "greater evil": "the state is justified in taking human life only if that taking of the human life protects society against a greater evil" - House of Commons Debates (16 May 1973), 3846 (David Lewis, MP - NDP, York South, ON).
} 
propriety of the death penalty not only through invocation of transcendent realities, but also through impressionistic language, contrasting killers with "innocent victims" or describing killers with terminology that blended connotations of moral guilt with images of concrete dangerousness.

While sometimes uncertain about the moral capacity of lawbreakers or the consequences morally warranted by offences, many abolitionists retained a strong sense of their own obligation, and that of other debate participants, to act ethically. Accordingly, rather than drawing attention to offenders' interests, merits, or deserts, various abolitionists sought to place the moral condition of themselves and their fellow law-abiding citizens in the spotlight. ${ }^{75}$ Sometimes invoking principle, sometimes appealing to a more impressionistic sense of the human position within nature and time, abolitionists called for Canadians to avoid the moral taint of killing or vengeance, and to operate on an ethical level superior both to that of the past and to that presently attractive to their own less admirable inclinations. Though the majority of the citizenry probably did not think along such idealistic lines, these progressive moral claims, especially the criticism of revenge, carried enough cultural credibility to discourage retributively oriented retentionist argument. This dynamic helped to keep much of the debate within an instrumentalist frame of reference, if not centred on progressive ideals themselves. Without conducting primary research from earlier and later periods, it is difficult

\footnotetext{
${ }^{75}$ For a document that particularly helped to stimulate this sentence and that contains a passage in many respects similar to my statement, see LAC, MG32, Series B35 (Walter Gilbert Dinsdale fonds), Volume 79, File 2 - File Title: "Capital Punishment. General 1973," The Administrative Board of the Canadian Catholic Conference and W.E. Power, President, to Hon. Members of the Senate and the House of Commons, January 26, 1973.
} 
to assess the degree to which Canadians tended to think about capital punishment within transcendent or progressive moral frameworks during other portions of the twentieth century. Accordingly, this study does not claim that the moral culture described here was unique to the 1957-1976 era. In relation to the story told in the following chapters, what sets this period apart is primarily the bundle of events and new information on the death penalty that came Canadians' way. However, whether the prevailing moral culture was new or long-established, soon to change or long to endure, it pivotally influenced the way in which Canadians argued about capital punishment during the period examined here. How it did this will be shown in the chapters ahead. 


\section{Chapter 2: To Deter or Not To Deter: How That Became the Question}

The Reverend E.L.H. Taylor had been considering the issue of capital punishment, and he felt uneasy about the ideas he was encountering. True to form, he decided to speak his mind on the matter to the readers of the Globe and Mail. His letter appeared in the paper on April 18, 1958. "The argument that capital punishment should be abolished because it does not always act as a deterrent," declared Taylor, "is surely utterly irrelevant to the basic issue involved, namely, that justice be done." Moreover, "[t]hat deterrence has, in fact, become the chief consideration in the modern discussion of this question, is a measure of how low modern ideas of law and justice have fallen."1

We will return to Taylor's ideas in more detail before long. However, quite apart from the main point of his letter, when Taylor observed that public analysis of the deathpenalty controversy in mid-century Canada tended to give foremost attention to the issue of deterrence, he was pointing to a phenomenon worthy not only of philosophical interest at the time, but also of historical interest today. Some recent studies have called attention to the significant degree to which historical attitudes toward execution in Western societies have drawn inspiration from a retributive vision of punishment. ${ }^{2}$ That is, many people have believed that criminal conduct simply makes an offender deserving of penalties, with desert serving both as the prerequisite for punishment in the first place and

\footnotetext{
${ }^{1}$ (Rev.) E.L.H. Taylor, letter to the editor, Globe and Mail, April 18, 1958, p. 6.

${ }^{2}$ See Richard J. Evans, Rituals of Retribution: Capital Punishment in Germany, 1600-1987 (Oxford: Oxford University Press, 1996), viii; see Mark Arron, "Punishment and Civilization: A Case Study of the Canadian Capital Punishment Debate of 1987" (Ottawa: National Library of Canada, 1995 - M.A. Thesis, University of Manitoba, 1994), 61-67, 74-75, 99-101; see Banner, Death Penalty: An American History, 13-16, 116, 282-284.
} 
as a guide for selecting the appropriate quantity of punishment. ${ }^{3}$ These historical studies highlight retributive perceptions of capital punishment primarily because they deal with times and places in which retributive thinking did indeed exercise significant influence. At the same time, the authors' attention to retribution in history probably results in part from the prominence of retributive ideas in recent philosophical and political deliberation about the current use of the death penalty. ${ }^{4}$ However, neither the influence of the retributive vision in Western history as a whole nor the currency of retributive considerations for present-day thinkers should distract us from the importance of deterrence-centred reasoning to mid-century Canadians. ${ }^{5}$ As we will see, many citizens did assess whether retributive principles offered any worthwhile guidance concerning the death penalty. But at least in the type of public forums examined in this thesis, the debate as a whole tended to privilege questions about deterrence. Would people kill their fellows more rarely, asked Canadians, in a society where such behaviour qualified the offender for execution, rather than merely for incarceration?

Deterrence-related arguments dominated the debate both quantitatively and qualitatively. During the debates in the House of Commons on the various death-penalty-

${ }^{3}$ For a concise summary of retributive theory, see Louis P. Pojman, "For the Death Penalty," in Louis P. Pojman and Jeffrey Reiman, The Death Penalty: For and Against, 7-22 (Lanham, MD: Rowman \& Littlefield Publishers, 1998).

${ }^{4}$ See particularly Evans, Rituals of Retribution, viii n. 1, 906, 910; see also Banner, Death Penalty: An American History, 282-283, 310-311. For an example of the strength of retributive thought in recent years, see Pojman and Reiman, The Death Penalty: For and Against, in which both the author defending capital punishment and the one critiquing it couch their arguments within a retributive penal philosophy. On the strength of retributive thought in recent years with respect to criminal punishment more generally, see Strange, "Introduction," 12.

${ }^{5}$ This is not to suggest that the writers mentioned above failed to give due attention to the strength of deterrence-centred thinking in this and other time periods. See Banner, Death Penalty: An American History, 216-219, 279-281. 
related bills proposed between 1957 and 1976, parliamentarians discussed deterrence more than any other issue, with over half of their speeches addressing the issue in some manner. ${ }^{6}$ While deterrence received far less discussion in letters to the Globe and Mail and Toronto Daily Star, it still numbered among the topics that these letters addressed most often, with many writers from both camps having a go at the matter. Of equal importance as the frequency with which debaters discussed deterrence was the extent to which their claims about this sub-issue undergirded their overall arguments concerning the death penalty. In the case of each major abolitionist bill or parliamentary resolution, the MP making the lead-off speech in the House of Commons built a central part of his argument around the notion that capital punishment lacked the capability to extend deterrence beyond the level achievable through non-lethal penalties. ${ }^{7}$ Prime Ministers

\footnotetext{
${ }^{6}$ In the case of both the 1961 and the 1967 death-penalty-related legislation, Hansard recorded the debate "in Committee of the Whole" that occurred in the House of Commons subsequent to the secondreading vote and prior to third-reading debate - see Journals of the House of Commons of Canada, $4^{\text {th }}$ Session, 24 $4^{\text {th }}$ Parliament, Volume 107, No. 114 (24 May 1961), and No. 124 (5 June 1961); Journals of the House of Commons of Canada, $2^{\text {nd }}$ Session, $27^{\text {th }}$ Parliament, Volume 114, No. 86 (23 November 1967), and No. 91 (30 November 1967); and the relevant sections of House of Commons Debates between May 24 and June 5, 1961, and between November 23 and November 30,1967. MPs' verbal contributions to these Committee of the Whole debates sometimes constituted full speech-length statements and sometimes consisted of somewhat shorter statements. My assertion that over half of parliamentary capital-punishmentrelated speeches addressed the topic of deterrence is based on a count of speeches that does not include any speeches/statements from these Committee of the Whole debates in the figure for total speeches made. However, my totals do include capital-punishment-related speeches occurring in the House of Commons between the second- and third- reading debates for both the 1973 and the 1976 legislation.

Also, in the 1976 parliamentary debate, the number of speeches containing discussion of public opinion slightly exceeded the number containing discussion of deterrence, but over the period of study as a whole, MPs' speeches dealt with the latter topic more often than with the former.

${ }^{7}$ See House of Commons Debates (18 February 1960), 1187-1192 (Frank McGee - Progressive Conservative, York-Scarborough, ON); (23 March 1966), 3068-3071 (Terence Nugent, MP - Progressive Conservative, Edmonton-Strathcona, AB); (9 November 1967), 4077-4082 (Larry Pennell, MP - Liberal, Brant-Haldimand, ON); (26 January 1973), 686-692 (Warren Allmand, MP - Liberal, Notre-Dame-deGrâce, QC); (3 May 1976), 13088-13091 (Warren Allmand, MP). Although death sentencing no longer occurred for a large proportion of murders after 1961 due to the capital/non-capital distinction applied to murders through Bill C-92, I am here not counting this bill as abolitionist legislation, since the capitalmurder category it established did still encompass a substantial number of killings, and since the Conservative administration employed a largely retentionist spin in introducing the bill - see Strange,
} 
and Leaders of the Official Opposition typically voiced similar reasoning. ${ }^{8}$ Some other abolitionists cast deterrence as the decisive point of analysis. The degree of deterrence generated by capital punishment relative to that emerging from other sanctions constituted "the sole question to be determined and the only question we are called upon to decide," stated one MP.9 Occasionally retentionists made similar claims. "If capital punishment is not a deterrent to crime," declared one, "then there is no reason to retain it as a penalty in our Criminal Code. This debate, then[,] boils down to whether or not capital punishment serves as a deterrent to crime." ${ }^{" 10}$ When a 1971 Gallup poll sought to discover both the what and the why of Canadians' stance on the death penalty, over sixty percent of retentionists validated their position by reference to the heightened frequency of murder and/or to the deterrence available through capital punishment. ${ }^{11}$ In short,

"Lottery of Death," 617; see C.H.S. Jayewardene, The Penalty of Death: The Canadian Experiment (Lexington, MA: Lexington Books, D.C. Heath and Company, 1977), 5-6; see House of Commons Debates (23 May 1961), 5220-5226 (E.D. Fulton - Progressive Conservative, Kamloops, BC). Fulton, front man for this bill, placed less stress on the dispute over deterrence in this lead-off speech.

${ }^{8}$ See House of Commons Debates (16 November 1967), 4367-4372 (Lester Pearson, MP - Liberal, Algoma East, ON); (16 May 1973), 3842-3844 (Pierre Trudeau, MP - Liberal, Mount Royal, QC); (16 May 1973), 3844-3846 (Robert Stanfield, MP - Progressive Conservative, Halifax, NS); (7 June 1976), 1421514217 (Joe Clark, MP - Progressive Conservative, Rocky Mountain, AB); (15 June 1976), 14499-14501 (Pierre Trudeau, MP).

${ }^{9}$ House of Commons Debates (18 February 1960), 1198 (Arthur Maloney, MP - Progressive Conservative, Parkdale, $\mathrm{ON}$ ).

${ }^{10}$ House of Commons Debates (4 April 1966), 3831 (W.H.A. Thomas, MP - Progressive Conservative, Middlesex West, ON). For a similar, though not quite as strong, statement, see House of Commons Debates (14 November 1967), 4261-4262 (Douglas Harkness, MP - Progressive Conservative, Calgary North, AB).

${ }^{11}$ Canadian Institute of Public Opinion, "63\% Want Death Penalty Restored for Murderers," news release (The Gallup Report), February 2, 1972. This press release used the wording "Number of murders has increased; need death penalty as a deterrent to crime" to describe the rationale that sixty-four percent of the polled retentionists had invoked. The release does not explicitly indicate whether the listed rationales were offered to poll respondents as multiple-choice options or whether they were categories into which respondents' own answers were sorted, and it is not completely clear whether sixty-four percent of retentionists had mentioned both the murder rate and deterrence or simply one or the other. However, other scholars do seem to have interpreted the results as meaning that sixty-four percent had mentioned deterrence. See Chandler, Capital Punishment in Canada, 72-73 n. 35; Neil Vidmar, "Retributive and Utilitarian Motives and Other Correlates of Canadian Attitudes toward the Death Penalty," Canadian 
deterrence won more recognition as a matter of high import than any other issue within the overall debate on capital punishment.

Admittedly, this is scarcely surprising. A straightforward desire to keep society as murder-free as possible certainly fueled interest in questions concerning deterrence, as well as people's thinking about capital punishment in general. In addition, the matter of deterrence had long held a central place in Canadians' outlook on the death penalty. For instance, capital punishment came under fire from MP Robert Bickerdike and likeminded parliamentarians in $1914,{ }^{12}$ but several retentionist MPs pointed to the deterrent dynamics allegedly created by this lethal sanction, finding reassurance therein that his abolitionist initiative should be rejected. ${ }^{13}$ Furthermore, opinion leaders in the postwar years typically represented deterrence as the proper point of dispute concerning the death penalty. Sir Emest Gowers, the individual leading the Royal Commission on Capital Punishment in Great Britain between 1949 and 1953, wrote in a subsequent book that the argument that without the uniquely deterrent value of capital punishment more murders would be committed ... is the only serious utilitarian argument in favour of capital punishment, and the one on which thoughtful supporters of it almost wholly rely. ${ }^{14}$

Frank McGee, a leading abolitionist MP in the late 1950s and early 1960 s, gladly quoted

\footnotetext{
Psychologist 15, no. 4 (October 1974): 339.

${ }^{12}$ See, for example, House of Commons Debates (5 February 1914), 482-483 (Robert Bickerdike, MP - Liberal, St. Lawrence, QC); (5 February 1914), 493-496 (George P. Graham, MP - Liberal, Renfrew South, ON); (5 February 1914), 508 (Alphonse Verville, MP - Labour, Maisonneuve, QC).

${ }^{13}$ See House of Commons Debates (5 February 1914), 490-491 (George Foster, MP Conservative, Toronto North, ON); (5 February 1914), 491-492 (F.B. Carvell, MP - Liberal, Carleton, NB); (5 February 1914), 497-499 (W.F. Nickle, MP - Conservative, Kingston, ON); (5 February 1914), 509-510 (Frank Oliver, MP - Liberal, Edmonton, AB).

${ }^{14}$ Ernest Gowers, A Life for a Life? The Problem of Capital Punishment (London: Chatto and Windus, 1956), 137; see also 7-8, 134-136, 138.
} 
this statement in the Canadian House of Commons. ${ }^{15}$ Devoting attention to deterrence not only associated debaters with "thoughtful" people, but also enabled some abolitionists to feel confident that their case ran little risk of being in error. Capital punishment could not outperform the prison sentence as an inducement to avoid murder, indicated one abolitionist, observing that this point could claim the endorsement of "criminologists, sociologists and royal commissions which have been engaged in a full-time study of this problem."16

But these factors fail to provide a complete explanation. Debaters' tendency to talk about deterrence also resulted to a significant degree from prevailing moral sensibilities. Deterrence would appear to be an issue for the practically minded; indeed, this pragmatic flavour did much to make the topic attractive. In this case, however, being practical did not appeal only to those who preferred to avoid theory or moralism. Rather, widespread moral assumptions led citizens to believe that they should think pragmatically about the controversy. ${ }^{17}$ Many citizens, perhaps even the majority of them, remained ready to adjudge capital punishment morally legitimate if murder could be significantly suppressed through this sanction. Debaters could draw on Catholic moral thought in particular to buttress this point of view, claiming that a correct assessment of the death

\footnotetext{
${ }^{15}$ House of Commons Debates (18 February 1960), 1192 (Frank McGee, MP - Progressive Conservative, Yörk-Scarborough, ON).

${ }^{16}$ House of Commons Debates (15 November 1967), 4314 (Jack Roxburgh, MP - Liberal, Norfolk, ON).

${ }^{17}$ Occasionally abolitionists made observations about retentionists that at least broadly implied the same type of argument I am making here, although at least in the case of the two following examples, the point is put rather differently - see (Rev.) J. Franklin Chidsey, letter to the editor, Globe and Mail, April 23, 1958, p. 6; Lawrence La Fave, letter to the editor, Globe and Mail, December 23, 1972, p. 7. However, my point is meant to apply to abolitionists to some extent as well.
} 
penalty could occur only through weighing the issue in relation to the real needs of the citizenry as a whole. On the other hand, although some religious Canadians believed that capital punishment, whatever its concrete effect on the murder rate, simply accorded with divinely validated transcendent justice, this view collided with a widespread distrust of retributive thinking. Many Canadians believed that engaging in coercion or inflicting harm - especially when the harm in question was death - could be acceptable only if done in the course of efforts to produce a tangible greater good. Moreover, many believed that to speak of lethal retributive punishment was simply to speak of vengefulness unleashed, a phenomenon which progressive ideals judged to be beyond the pale. These various ethical suppositions, which left their mark on both retentionists' and abolitionists' arguments, ensured that neither assigning first priority to the offender's well-being nor punishing him out of retributive principle could become the predominant penal goal espoused by Canadians in public discourse. But punishing in order to lessen the potential for further crime seemed to be relatively non-objectionable, and deterrence therefore appeared to provide a morally suitable point of reference by which to evaluate the death penalty.

\section{Catholic Thought and the Common Good}

Writing to an acquaintance late in February 1960, abolitionist MP Herbert Herridge commented on the recent parliamentary debate on the death penalty. "The French Canadians," he noted, "are solidly opposed to the abolition of capital punishment and 
quoted extensively from the Bible to support their arguments."18 The French-Canadian MPs who had addressed the House had indeed carried the retentionist banner, and some of them did place great weight on biblical passages. ${ }^{19}$ However, biblical quotation was not the only notable characteristic of the francophone parliamentarians' speeches on capital punishment during the period of this study. Another distinctive feature consisted of their recurrent references to "the common good." Although this particular phrase and its cognates appeared especially often in the speeches of a certain group of Canadians, the basic concept provided a central pillar of both retentionist and abolitionist reasoning.

Several days before Herridge wrote his letter, MP Rémi Paul had explicated the principles that in his view made death-penalty law a worthy part of criminal justice. "The common good" formed a crucial element of his argument. "Law must have as its direct purpose the common good," declared Paul in the House of Commons. "Any law," he repeated , "must ... provide, first of all, for the general good, the good of the community, and if the law is to cover the individual as a unit, it must do so in so far as the individual co-operates to the good of the community or of society as a whole." Provided that capital punishment would make murder too unappetizing a meal for some potential killers to chew, and would thereby minimize the citizenry's vulnerability to homicidal activity,

\footnotetext{
${ }^{18}$ LAC, MG32, Series C13 (Herbert W. Herridge fonds), Volume 21, File Title: "Capital Punishment - general, 1954, 1956-61, 1964-65 (File 1)," Herridge to Reverend Allan Dixon, February 26, 1960. Herridge was a CCF MP for Kootenay West, BC. In this thesis I have largely relied upon the Web site of the Parliament of Canada for information on the party affiliation and ridings of the MPs discussed. See http://www.parl.gc.ca/information/about/people/house/mpsparl.asp?Language=E\&parl=95.

${ }^{19}$ Ten French-Canadian members spoke for retention and two for abolition - see House of Commons Debates (18 February 1960), 1200-1208, 1217-1220; (25 February 1960), 1446-1451, 1458 1463, 1466-1468. For those offering biblical quotations, see House of Commons Debates (18 February 1960), 1205 (Guy Rouleau, MP - Liberal, Dollard, QC); (25 February 1960), 1447 (Roger Parizeau, MP Progressive Conservative, Lake St. John, QC), 1459-1460 (Alexis Caron, MP - Liberal, Hull, QC).
} 
retention stood as the obvious legislative choice. After all, "[t]o consult general interest and to act according to its requirements ... is the duty of those who lead the people and legislate." ${ }^{20}$ Parliamentarians from Quebec repeated the theme a number of times in the 1960s. "[T]he first and immediate duty of the state is to make the general or common interest prevail over personal interest," affirmed one. ${ }^{21}$ "Because the government of a country has the duty to protect and defend the common good," insisted another, "it has the right to take the necessary legal steps to protect the physical, moral, emotional and intellectual welfare of the community as a whole." ${ }^{22}$ Some kept the terminology alive in the debates of the 1970s. In answer to the claim that capital punishment might someday claim the life of someone erroneously judged guilty of a killing, one MP argued that such an eventuality, besides falling within the rare-if-ever category of occurrences in the Canadian context, could not overrule a "duty strongly demanded by the common good."23

The primary factor uniting those who employed the terminology of "the common good" was not actually French-Canadian culture so much as a shared Roman Catholic heritage. This idiom also appeared in the language of certain English-Canadians,

\footnotetext{
${ }^{20}$ House of Commons Debates (18 February 1960), 1217-1218 (Rémi Paul, MP - Progressive Conservative, Berthier-Maskinongé-Delanaudière, QC).

${ }^{21}$ House of Commons Debates (24 May 1961), 5311-5312 (Robert Lafrenière, MP - Progressive Conservative, Québec-Montmorency, QC).

${ }^{22}$ House of Commons Debates (28 March 1966), 3317 (Yves Forest, MP - Liberal, Stanstead, QC).

${ }^{23}$ House of Commons Debates (30 January 1973), 783 (Gaston Clermont, MP - Liberal, Gatineau, QC). For some of the other speeches in which French-Canadian parliamentarians referenced "the common good," "the common weal," "the common welfare," and so forth, see House of Commons Debates (23 March 1966), 3081-3082 (Alcide Simard - Ralliement Créditiste, Lac-Saint-Jean, QC); (5 April 1966), 3871 (Paul Langlois, MP - Liberal, Chicoutimi, QC); (5 April 1966), 3896 (Jean-Paul Matte - Liberal, Champlain, QC); (26 January 1973), 700 (C.-A. Gauthier - Social Credit, Roberval, QC); (16 May 1973), 3849 (Henry Latulippe - Social Credit, Compton, QC); (24 May 1973), 4057 (Réal Caouette - Social Credit, Témiscamingue, QC).
} 
especially of some who spoke from a Catholic position or background. Appeals to the common good with respect to capital punishment carried a strong Catholic precedent, to put it mildly. Such a line of reasoning could, for example, be found in the Summa Theologiae, where Saint Thomas Aquinas had written that "if any man is dangerous to the community and is subverting it by some sin, the treatment to be commended is his execution in order to preserve the common good." 24 However, if placing the common good at centre stage led some Canadians toward the retentionist camp, others used this emphasis on communal needs for abolitionist purposes. One individual to respond in this manner was an anglophone Catholic who may also have been the most prominent Canadian abolitionist during the period of this study — defence counsel Arthur Maloney. $^{25}$

Few lawyers in Canada won as much prestige as Maloney during the third quarter of the twentieth century. However, his legal prowess could not nearly produce a one hundred percent rate of courtroom victory. One lost trial in 1952 stood out grimly, with the two men on whose behalf he had spoken biting the dust via execution shortly afterwards, since they had entered the dock on a charge of murder. Whatever the precise nature of his views on capital punishment before, he became a far more heartfelt enemy

\footnotetext{
${ }^{24}$ Thomas Aquinas, Summa Theologiae, [vol. 38, Injustice, ed. and trans. Marcus Lefébure, O.P. (New York: Blackfriars / McGraw-Hill Book Company; London: Blackfriars / Eyre \& Spottiswoode, 1975)], 2a2ae, Question 64, Article 2. I owe this reference to secondary sources, especially James J. Megivern, The Death Penalty: An Historical and Theological Survey (New York/Mahwah, NJ: Paulist Press, 1997), 117, 518 n. 52.

${ }^{25}$ On Maloney's Catholicism and abolitionist endeavours, see Charles Pullen, The Life and Times of Arthur Maloney: The Last of the Tribunes (Toronto: Dundum Press, 1994), including 39, 69, 206-211; see also The Canadian Who's Who, vol. IX, 1961-1963 (Toronto: Trans-Canada Press, 1963), s.v. "Maloney, Arthur."
} 
of the death penalty after having fought to defend men who in the end had to swing.

Besides being against capital punishment in general, Maloney reputedly found various specific executions to be a source of real personal distress, and he actively tried to convince Canadian citizens and leaders to forego the death penalty both through legislative abolition and, at least in the Marcotte case, through clemency. ${ }^{26} \mathrm{He}$ publicized the abolitionist message before fellow lawyers, in the House of Commons during his 1957-1962 stint as a parliamentarian, and as a mouthpiece for the Canadian Society for the Abolition of the Death Penalty, which came into being in 1964 and soon placed Maloney in the president's chair. ${ }^{27}$

In some respects Maloney exemplified the increasing tendency to view the provision of justice - in this case, with respect to the death penalty - from within a procedural frame of reference. More than most abolitionists, he argued that the uniqueness of each of the various individuals involved in a given trial stymied the perfect fairness that standard procedure was supposed to provide. As a result, he claimed, the sentences pronounced or implemented would certainly fail to maintain the same proportional relationship between crime, circumstance, and consequence for each

\footnotetext{
${ }^{26}$ See Pullen, Arthur Maloney, 2-7, 69, 77-78, 81-89, 129, 137, 204-211, 326, 353; see "Maloney Appeals for Santa Bandit," Toronto Daily Star, December 3, 1964, 4. See also LAC, MG32, Series B27 (Marcel Lambert fonds), Volume 81, File 6 - File Title: "Capital Punishment 1964-1965," The Canadian Society for the Abolition of the Death Penalty, Information Bulletin 1 ([Toronto, ON]: The Canadian Society for the Abolition of the Death Penalty, [1964]), 9.

${ }^{27}$ See "The Abolition of Capital Punishment," Canadian Bar Review 32, no. 5 (May 1954): 485, 486-490. The latter five pages record a speech Maloney made at a Canadian Bar Association gathering for the Ontario region. See also Pullen, Arthur Maloney, 137, 204, 207-208; see also LAC, MG32, Series B27 (Marcel Lambert fonds), Volume 81, File 6 - File Title: "Capital Punishment 1964-1965," The Canadian Society for the Abolition of the Death Penalty, Information Bulletin 1 ([Toronto, ON]: The Canadian Society for the Abolition of the Death Penalty, [1964]), 1-3. It is not clear from this source whether Maloney was immediately made president at the inception of the organization or whether this occurred after a short lapse of time.
} 
offender - a situation that, whatever people might think of it in general, seemed unconscionable when life could be the lot of one convict and death the portion of another. ${ }^{28}$ But Maloney's concerns went far beyond procedure and its weaknesses; other moral claims contributed to his abolitionist advocacy as well. One such claim concerned the common good.

When Rémi Paul stood in the House of Commons in February 1960 to link the common good to the retentionist cause, Maloney had already tried several hours earlier to hamess it for the abolitionist side. While other abolitionists sometimes suggested that executing a citizen intrinsically failed to qualify as a morally acceptable action for the state to perform, ${ }^{29}$ Maloney sang a different tune. "The moral right of the state to exact the penalty of death in the case of a convicted criminal if it is necessary for the common good is something which cannot in my mind be seriously questioned," he admitted. But if, as Maloney believed, the existing level of deterrence to murder could be maintained while switching from lethal to non-lethal sanctions, why not ditch the death penalty, since nothing to society's detriment would result from such a move? He also pointed out potential direct moral problems with capital punishment, but having recognized the

\footnotetext{
${ }^{28}$ See House of Commons Debates (18 February 1960), 1199 (Arthur Maloney, MP - Progressive Conservative, Parkdale, ON); see Arthur Maloney, "Death Penalty: Facts Can't Justify Even Partial Retention," Toronto Daily Star, January 19, 1973, p. 6; see LAC, MG32, Series B35 (Walter Gilbert Dinsdale fonds), Volume 79, File 5 - File Title: "Capital Punishment. General. Feb.-July 1976," transcript of 25 May 1976 meeting for parliamentarians in Railway Committee Room with panel of speakers sponsored by Canadian Society for the Abolition of the Death Penalty, pp. 6-12 (speech by Arthur Maloney); see Strange, "Undercurrents," 364.

${ }^{29}$ See House of Commons Debates (24 March 1959), 2203 (Margaret Aitken, MP - Progressive Conservative, York-Humber, ON); (16 June 1959), 4963 (C.W. Carter - Liberal, Burin-Burgeo, NF); (16 June 1959), 4965 (Hubert Badanai, MP - Liberal, Fort William, ON); see (Rev.) J. Franklin Chidsey, letter to the editor, Globe and Mail, April 23, 1958, p. 6; J. Clarence Boyle, letter to the editor, Globe and Mail, February 18, 1960, p. 6; Aaron Carbell, letter to the editor, Globe and Mail, February 25, 1960, p. 6.
} 
common good as a factor creating theoretical space for ethical executions, he remained content to invest his argumentative capital largely in the purported lack of an actual reason to put this "horrible" and "drastic" sanction to work. In Maloney's eyes, such a reason would remain endlessly elusive if it could not be found under the banner of deterrence. Accordingly, the dispute over deterrence provided the field on which the retentionist and abolitionist factions would do battle, and Maloney felt confident that his side would win. $^{30}$

Maloney was not playing a lone hand. Broadly speaking, the place he gave to consideration of the common good aligned with the outlook of important Catholic religious leaders, and certain fellow abolitionists pursued a line of argument similar to his. The Canadian Catholic Conference (CCC) spoke to the death-penalty issue as the 1960 parliamentary debate was about to begin, with the CCC's words appearing in the Ottawa Citizen on the same day on which Maloney addressed Parliament. The CCC provided no endorsement of abolition, but it did place "the common good" and what was "necessary" in the spotlight, without assuming that such criteria left retention as the obvious choice. "[A] state has the right - indeed, the duty and the obligation from God — to protect its citizens from harm," declared the CCC. Accordingly, "[w]hen a criminal gravely endangers the common good by evil-doing, the state has the right to put him to death, if necessary." At the same time, "the Catholic Church has never either demanded or urged capital punishment as the only means of punishing criminals or preventing

\footnotetext{
${ }^{30}$ House of Commons Debates (18 February 1960), 1198-1200 (Arthur Maloney, MP Progressive Conservative, Parkdale, ON). The quotations are from pages 1198 and 1199.
} 
crime. It is for the state to decide whether capital punishment is opportune or necessary in a given case, or in a general situation."31 Two weeks later Gordon George, a leading Canadian Jesuit whose religious commentary appeared often in the Globe and Mail, made use of similar principles when explaining why, in his "personal opinion," abolition deserved support. George suggested that penal measures should indeed provide what was "necessary to the peace and good order of society," but he considered the death penalty not to be "necessary to protect the common good in modern times," given its merely mediocre deterrent achievements. ${ }^{32}$ Catholic MP Frank McGee, whose private member's bill for abolition had been the topic of the 1960 debate, did not tend to stress this line of thinking in his speeches, but he came to feel that Canadians had received too little exposure to the argument. The Ottawa Citizen article containing the CCC declaration had carried the rather misleading headline "Duty of State to Hang Murderers, RC's Insist." When McGee argued for abolition in the House of Commons once more in 1961, he pointed out the Citizen's error and quoted another source that gave a strong abolitionist twist to the common-good refrain:

"The state possesses authority from God to take the life of a criminal only when such a penalty is necessary to preserve the common good of all.

"If it should be discovered that long imprisonment serves equally well in deterring crime, then the death penalty would have to be abolished, for as soon as

${ }^{31}$ Quoted in Ottawa Citizen, final edition, "Duty of State to Hang Murderers, RC's Insist," February 18, 1960, p. 13. This statement can also be found in J. Gordon Melton, ed., The Churches Speak on: Capital Punishment: Official Statements from Religious Bodies and Ecumenical Organizations (Detroit: Gale Research Inc., 1989), 1-2.

${ }^{32}$ Gordon F. George, "Final Justice Up to Creator," Globe and Mail, final edition, March 5, 1960, p. 8. For evidence that George wrote for the Globe on many other occasions, see "Canadians and Their Religion - A New Globe and Mail Feature," Globe and Mail, March 14, 1959, p. 8, and the introductory note to Gordon F. George, "Thou Shalt Not Kill," Globe and Mail, November 14, 1960, p. 7. 
the need for it ceases, the state no longer possesses God's authority to use it."33

When Catholic abolitionists encouraged their audience to think of the death-

penalty controversy in relation to what "is necessary for the common good," 34 they were

moving the capital-punishment dispute onto terrain occupied both by Catholic

retentionists and by many other Canadians. Such an approach brought the abolitionist

case into line with an important moral assumption shared by many citizens and helped to

focus the dispute on the workings of crime deterrence. Although citizens of non-Catholic

background do not appear to have used the phrase "the common good" so often, many did

believe that sound ethics would make authorities more hesitant to expose the citizenry at

large to harm than to let harm befall an individual lawbreaker as a consequence of his

action. "We are not here to protect criminals from the gallows," declared one MP to his

fellows in the House of Commons. "We are here to protect society in general."35

${ }^{33}$ See House of Commons Debates (28 April 1961), 4131-4132 (Frank McGee, MP - Progressive Conservative, York-Scarborough, ON). The quotation appears on page 4132. Although McGee's description of the origins of this quotation are slightly ambiguous, it appears that it was from the Toronto Telegram, or that it had at least appeared there. McGee calls it a "statement" that Telegram editorialist Ed Mahoney had "placed on the record of his own newspaper, and I presume others." For the offending Ottawa Citizen headline, see Ottawa Citizen, final edition, "Duty of State to Hang Murderers, RC's Insist," February 18, 1960, p. 13. On McGee as the sponsor of the debated 1960 bill, see House of Commons Debates (18 February 1960), 1187 (Frank McGee, MP - Progressive Conservative, York-Scarborough, ON); see also LAC, RG2, Privy Council Office, Series A-5-a, Volume 2746, Cabinet Conclusions, No. 1860, February 2, 1960, p. 2-3. For evidence of McGee's Catholicism, see The Canadian Who's Who, vol. IX, 1961-1963 (Toronto: Trans-Canada Press, 1963), s.v. "McGee, Hon. Frank C." Another MP made a statement of virtually identical wording to the McGee quotation above, prefaced by "My faith teaches me that" - see House of Commons Debates (25 February 1960), 1452 (E.L. Morris, MP - Progressive Conservative, Halifax, NS). Note also that Morris received high-school education at St. Mary's College High School - see "Edmund Morris, 1924-2003," The Times (St. Mary's University, Halifax, Nova Scotia) 34, no. 1 (April 2003), http://www.smu.ca/thetimes/t2003-04/morris.html (accessed December 12, 2006). For a broadly similar use of "the common good" in an abolitionist argument of non-religious tone, see Prof. Gaston Laurion, letter to the editor, Globe and Mail, August 17, 1964, p. 6.

${ }^{34}$ House of Commons Debates (18 February 1960), 1198 (Arthur Maloney, MP - Progressive Conservative, Parkdale, ON).

${ }^{35}$ House of Commons Debates (23 May 1961), 5276 (W. Earl Rowe, MP - Progressive Conservative, Dufferin-Simcoe, ON). For a related example, see House of Commons Debates (24 March 1966), 3127 (Jack Horner, MP - Progressive Conservative, Acadia, AB). 
Statistical data, incarceration, and rehabilitation might allow MPs to say confidently that in almost no case would a second individual suffer death at the hands of a former murderer who had been convicted but not executed. But they could not say with full certainty that such would hold true for one hundred percent of future cases, worried one retentionist. So long as this slight uncertainty remained, he warned, "the state owes a higher duty to its law-abiding citizens, to its women and children, than it does to the criminal." ${ }^{\text {36 }}$ Among retentionists who did explicitly invoke the common good, some may have believed that the crucial needs of the community to be met through capital punishment extended beyond the practical issues of crime and safety. ${ }^{37}$ But the concept generally lent itself to discussion of tangible harms and benefits. Abolitionists had little difficulty implying that "protect[ing] the common good" largely amounted to ensuring that crime remained rare enough not to jeopardize citizens significantly. ${ }^{38}$ Accordingly, the discourse of the common good facilitated the discussion of deterrence, suggesting that it was not only practical to assess carefully the strength or weakness of the deterrent dynamics involved in capital punishment, but in fact morally crucial to do so.

By no means did all abolitionists think that the deterrent successes or failures of the death penalty should constitute the main point of debate, or that the death penalty could claim ethical propriety if it truly would divert future individuals from a murderous

\footnotetext{
${ }^{36}$ House of Commons Debates (5 April 1966), 3866-3867 (Gordon Churchill, MP - Progressive Conservative, Winnipeg South Centre, MB).

${ }^{37}$ See House of Commons Debates (24 May 1961), 5311-5312 (Robert Lafrenière, MP Progressive Conservative, Québec-Montmorency, QC); House of Commons Debates (28 March 1966), 3317 (Yves Forest, MP - Liberal, Stanstead, QC).

${ }^{38}$ See, for example, Gordon F. George, "Final Justice Up to Creator," Globe and Mail, final edition, March 5, 1960, p. 8.
} 
path. For instance, many saw offender rehabilitation as an ideal of immense import, and

to some this ideal made capital punishment morally untenable irrespective of the deterrent dynamics in play.: "As long as there remains a chance for rehabilitation," wrote one, "capital punishment is sinful." 39 Those who appealed for abolition on less categorical grounds, including Maloney himself, often still gained motivation for their stance from their deep interest in the present and future good of murder convicts. ${ }^{40}$ However, whatever they might have thought deep inside, on occasion abolitionists declared that retention would be appropriate, or at least that they would raise no voice against it, if someone were to provide a persuasive debunking of their claims about the deterrent mediocrity of the death penalty. In an article on the Canadian Society for Abolition of the Death Penalty, then headed by Maloney, the Toronto Daily Star reported that "[i]f it could be proved homocides [sic] would rise if the rope was abolished 'there' $d$ be wholesale resignations from our board of directors,' Maloney said." " “[ ] $\mathrm{f}$ I and others

${ }^{39}$ J.K. Payne; letter to the editor, Globe and Mail, April 23, 1958, p. 6. For just a few other examples of abolitionists especially focused on rehabilitation, see Mrs. George Steel, Corresponding Secretary, The Elizabeth Fry Society, Toronto Branch, letter to the editor, Globe and Mail, final edition, December 19, 1962, p. 6; Allen D. Fraser, letter to the editor, Toronto Daily Star, April 4, 1966, p. 6; LAC, MG32, Series B35 (Walter Gilbert Dinsdale fonds), Volume 79, File 2 - File Title: "Capital Punishment. General 1973," copy of letter sent from A.B. Wilson to editor, Brandon Sun, January 22, 1973.

${ }^{40}$ On Maloney, see House of Commons Debates (18 February 1960), 1199-1200 (Arthur Maloney, MP - Progressive Conservative, Parkdale, ON); Pullen, Arthur Maloney, 355-356.

${ }^{41}$ Toronto Daily Star, "Hanging Abolitionists Wamed Work Hard, You Could Lose," January 31, 1966, p. 21. Maloney expressed this type of stance on more than one occasion - see Toronto Daily Star, "Police Accused of Lobbying to Keep Gallows," May 7, 1965, p. 52 (a clipping of this article is found in LAC, MG31, Series K24 [June Callwood fonds], Volume 27, File 4 - File Title: "Capital Punishment. Scripts by JC, correspondence, reference materials [3] n.d., 1963-1988"); see Arthur Maloney, "Does Retention Protect Police?" The Canadian Register (Kingston, ON), February 5, 1966, p. 5 (a clipping of this article is found in LAC, MG32, Series C31 [Heath Nelson Macquarrie fonds], Volume 42, File 32 File Title: "Capital Punishment 1966"); for a similar though not as strong statement, see National Research Committee, Canadian Society for the Abolition of the Death Penalty, "A Reply to the Submission of the Canadian Association of Chiefs of Police Dated February 6, 1965, and Addressed to all Members of Parliament at the Parliament Buildings, Ottawa," April 26, 1965, as reprinted in Department of Christian Social Service, Anglican Church of Canada, The Death Penalty? (Toronto: Department of Christian Social 
who take the same view I take were convinced that capital punishment was shown to be the most effective deterrent to murder, ... we would be compelled to support the continuation of capital punishment," declared the staunchly abolitionist MP Andrew Brewin. "If the evidence before us demonstrated that capital punishment protected society and saved lives," asserted another New Democrat, "I would not hesitate to support it." Whether this type of statement represented the stance of many abolitionists or only a few, whether it expressed a heartfelt conviction or merely a desire to present abolitionist goals in politically viable terms, such claims reinforced the public legitimacy of the notion that potential harm to the citizenry at large called for remedy with greater ethical urgency than did harm to offenders, and that the best way to decide for or against the death penalty was to explore the workings of deterrence.

In sum, reference to the common good, a concept particularly popular among adherents of Canada's largest church, aligned well with mainstream assumptions about how best to evaluate capital punishment. The significance of this philosophical idiom does not reside in the raw frequency of its appearance in either public debate or Catholic minds. Only a small percentage of parliamentary speeches contained this terminology,

Service, Anglican Church of Canada, n.d. [1965?]), 20.

${ }^{42}$ House of Commons Debates (23 March 1966), 3075 (Andrew Brewin, MP - NDP, Greenwood, ON).

${ }^{43}$ House of Commons Debates (15 May 1973), 3772 (Max Saltsman, MP - NDP, Waterloo, ON). For a similar but perhaps less committal statement by the prominent abolitionist Harold Winch (NDP, Vancouver East, BC), see House of Commons Debates (16 February 1962), 967-968. For additional statements along similar lines to those quoted in the paragraph, see House of Commons Debates (28 March 1966), 3308 (Max Saltsman, MP - NDP, Waterloo South, ON); (10 November 1967), 4149 (F.J. Bigg, MP - Progressive Conservative, Athabaska, AB); (16 November 1967), 4372 (Lester Pearson); (3 May 1976), 13094 (Andrew Brewin, MP - NDP, Greenwood, ON); (28 May 1976), 13951 (Louis Duclos - Liberal, Montmorency, QC); (4 June 1976), 14178 (Derek Blackburn, MP - NDP, Brant, ON); (13 July 1976), 15318 (Robert Stanbury, MP - Liberal, York-Scarborough, ON). In short, such abolitionist statements emerged in both the 1960s and 1970s. 
which appears to have been even rarer on letters-to-the-editor pages, and it is unclear whether a large proportion of lay Catholics thought along such lines. ${ }^{44}$ Instead, the discussion of the common good illustrates the capacity of the issue of deterrence to serve as a central focus of debate acceptable to a wide range of Canadians. Holding special credibility among Quebeckers and Roman Catholics, aligning with widespread attitudes toward criminal justice among other Canadians, and providing rhetorical possibilities for the defence of either retention or abolition, the discourse of the common good also merged easily with the discussion of deterrence. For many, therefore, moral thought and instrumental aims pointed in the same direction.

\section{Retribution and Its Opponents}

Not everyone agreed that the issue of deterrence held rightful claim to its position at the middle of the rhetorical battlefield. Some believed that, at least theoretically speaking, murder and execution belonged together as a natural pair. When a murder occurred, the execution of the killer should also occur, with the very complementarity of the latter event to the former making the lethal penalty morally appropriate, and with any practically advantageous consequences of execution being of only modest ethical significance, if of any at all. Many Canadians expressed their unwillingness to buy in to such a line of reasoning. As we shall see, this rejection of retributive claims would form a crucial element of the moral framework that encouraged debaters to view deterrence as

\footnotetext{
${ }^{44}$ Of the more than seven hundred speeches on capital punishment delivered in the House of Commons during the period covered by this study, at least twenty-eight made reference to "the common good," "common interest," "common weal," "common welfare," and so forth.
} 
the most important issue to discuss. But such resistance would have been unnecessary had not some citizens praised the virtues of the retributive outlook. Few Canadians did the latter in as much detail and with as much passion as the man introduced at the outset of this chapter, the Reverend E.L.H. Taylor.

His parents being missionaries, Eustace Lovatt Hebden Taylor spent at least part of his childhood in Africa. War duty and completion of a degree at Cambridge punctuated his young adulthood, and in the early 1950s he studied theology in Vancouver. Over the next decade, his vocation as an Anglican clergyman took him to the Yukon, the Montreal area, and rural communities in Quebec and Ontario. By the mid-1960s he had left the country, and after ministering in Great Britain for a time, he took up a new occupation as a sociology professor at Dordt College, a small liberal arts institution in Iowa promoting Reformed Christianity. It appears that Taylor loved to write, and few topics inspired his pen as much as the notion that citizens could discern optimal practices and conditions for the polity, economy, and society in general only by paying heed to Christian theology and Scripture. ${ }^{45}$ His ideas would eventually become available in book

\footnotetext{
${ }^{45}$ For biographical details on Taylor, see Hebden Taylor, Evolution and the Reformation of Biology: A Study of the Biological Thought of Herman Dooyeweerd of Amsterdam and J.J. Duyvene de Wit, late Professor of Zoology at the University of Bloemfontein, South Africa (Nutley, NJ: The Craig Press, 1967), vi, ix-xi; Hebden Taylor, The New Legality in the Light of the Christian Philosophy of Law (Philadelphia: Presbyterian and Reformed Publishing Company, 1967), [iii]; E.L. Hebden Taylor, Reformation or Revolution: A Study of Modern Society in the Light of a Reformational and Scriptural Pluralism (Nutley, NJ: The Craig Press, 1970), [i]; The Suburban Times, Obituaries, Rev. E.L. Hebden Taylor, September 3, 2006, http://www.thesubtimes.com/2006/09/obituaries.html (accessed November 25, 2006); E.L.H. Taylor, "Should the Death Penalty Be Retained in Canada? A Review of the Argument," His Dominion 9, no. 2 (May 1, 1960): 17; E.L.H. Taylor, "The Christian and the Modern World," His Dominion 11, no. 1 (February 1, 1962): 15; E.L. (Stacey) Hebden Taylor, "Retribution, Responsibility and Freedom: The Fallacy of Modern Criminal Law from a Biblical-Christian Perspective," Law and Contemporary Problems 44, no. 2 (Spring 1981): 51. http://www.jstor.org/. See also E.L. Hebden Taylor, Economics, Money and Banking (Nutley, NJ: The Craig Press, 1978). On Dordt College, see Dordt College Web site, "Our Philosophy" and "History," http://www.dordt.edu/about/our_philosophy/ and
} 
form, but in the late-1950s he readily seized the opportunity to speak his mind in bitesized pieces, repeatedly sending letters to the editor of the Globe and Mail. ${ }^{46}$ Some of these dealt with capital punishment, none more forcefully than that of April 18, $1958 .^{47}$

In this missive, Taylor unapologetically declared that the death penalty received the crucial nod of affirmation not from assessments of deterrence, but from the ideal of justice. "It is just that the killer must himself be killed," insisted Taylor. "He must make proper atonement, not to deter others - that would be to treat him as a mere means to some other end - but to restore the just order which he has made unstable." When Taylor wrote of "justice," he was not thinking merely of the state of affairs in which the humans within a given setting perceive matters as being arranged justly. Rather than existing primarily between the ears of human beings, justice was tied to a moral reality anchored in a transcendent God. "This notion of retribution underlies the Biblical conception of punishment," declared Taylor.

As St. Paul says: 'Be not deceived; God is not mocked: for whatsoever a man soweth, that shall he also reap.' (Gal. 6:7) If God were to let wrongdoing go unpunished, it would mean that His moral order had no force, and that He did not take His own moral law seriously.

Moreover, "[a]ll earthly criminal justice is based on the presumption of a Divine holy order which must not be infringed, and the infringement of which requires restitution,

http://www.dordt.edu/about/our_philosophy/history.shtml.

${ }^{46}$ See, for example, Taylor's letters in the Globe and Mail on August 5, 1958, p. 6; August 26, 1959, p. 6; December 16, 1959, p. 6; June 9, 1960, p. 6; September 19, 1960, p. 6; and April 19, 1961, p. 6.

${ }^{47}$ For other Taylor letters on capital punishment not discussed in this thesis, see the Globe and Mail for September 3, 1958, p. 6; December 29, 1959, p. 6; and January 9, 1960, p. 6; and the Toronto Daily Star, January 28, 1960, p. 6. 
atonement, punishment."48

Taylor's letter drew staunch rejoinders from fellow Globe readers, who disputed his claims on a variety of fronts. ${ }^{49}$ To some, Taylor seemed a little too ready to see an uppercase " $\mathrm{J}$ " when he read the word "justice." One correspondent believed that Taylor had missed the mark in invoking such notions as "the Divine order." "It is my opinion," wrote this abolitionist, "that the universe is probably morally and ethically neutral; any sense of value springs from humanity, and is not handed down from the deified crystallization of man's wish for cosmic security." ${ }^{.50}$ Admittedly, a counterclaim stated this strongly was no more typical (and perhaps even less so) of the debate as a whole than was Taylor's own offering. Most of his critics chose not to target their criticism at his efforts to define justice by reference to criteria other than human consciousness. But some of them did disagree with his apparent belief that people had long ago struck gold in their efforts to describe genuine justice, that their description retained perpetually sufficient value for present and future societies, and that modem thinkers were ruining everything through revisionism. "I trust," declared one letter writer, "that our understanding of justice will continue to progress, and that reason, not hysteria, will guide it." ${ }^{\prime 51}$

Although Taylor's strongly worded claims did not typify the Canadian capitalpunishment debate, he was far from the only one to make such statements about

${ }^{48}($ Rev.) E.L.H. Taylor, letter to the editor, Globe and Mail, April 18, 1958.; see also E.L.H. Taylor, "A Secular Revolution in Christian Disguise," Canadian Bar Joumal 1, no. 4 (August 1958): 44. 1958.

${ }^{49}$ For at least eight such letters, see the issues of the Globe and Mail for April 23 and April 24,

${ }^{50}$ J.K. Payne, letter to the editor, Globe and Mail, April 23, 1958, p. 6.

${ }^{51}$ Alan Stebbings, letter to the editor, Globe and Mail, April 23, 1958, p. 6. 
retribution and justice, as we shall see. For the moment, however, it is useful to consider other examples of opposition to this type of vision of justice. By continuing to press his case, Taylor himself gave such opposition a natural chance to surface. In the August 1958 issue of the Canadian Bar Journal, he wrote approvingly of the "notion of justice as eternal, supernatural and absolutely valid" - a notion to which the Western mind, encouraged by both Aristotelian and Christian antecedents, had long held fast, he maintained. With the vision "of Natural Law and Justice" forming an essential element of the Western conceptual world, "our Western ancestors" had "[f]or two thousand years" considered retributive execution to be the default plan of action for authorities who had to punish a murderer. Now, argued Taylor, "scientific humanists and utilitarian pragmatists" were seducing Canadians into reversing course. ${ }^{52}$ This time Osgoode Hall law professor John Desmond Morton unleashed an abolitionist counter-thrust. Like Taylor, Morton liked to share his thoughts in the public arena, at least when legal and penal affairs were the topics at hand, and he wrote to the Globe and Mail about the death penalty several times over the years. Possessed of fairly conservative instincts with respect to criminal justice in general, Morton nevertheless counted himself a convinced enemy of capital punishment. ${ }^{53}$ As part of his attempt to show Canadian Bar Journal

\footnotetext{
${ }^{52}$ E.L.H. Taylor, "A Secular Revolution in Christian Disguise," Canadian Bar Journal 1, no. 4 (August 1958): 41-46.

${ }^{53}$ For examples of Morton's contribution to public discussion that also give an interesting view of his changing perspectives on criminal justice as a whole, see J.D. Morton, The Function of Criminal Law in 1962: Five Lectures for Radio in the Series CBC University of the Air (Toronto: Canadian Broadcasting Corporation, 1962) (see page 4 for his abolitionist commitment), and LAC, RG36, Series 24 (Canadian Committee on Corrections sous-fonds), Volume 20, File Title: "Spare Copies - 'Talks' by Professor Desmond Morton." For letters and an op-ed piece by Morton on the death penalty, see the issues of the Globe and Mail for December 11, 1958, p. 6; December 19, 1959, p. 6; January 19, 1960, p. 6; November 24, 1962, p. 6; May 12, 1976, p. 7; and June 19, 1976, p. 7.
} 
readers why Taylor was wrong, Morton discussed the case of English society in the epoch preceding the High Middle Ages. He raised doubts that the constant and clear vision of "retributive justice" of which Taylor wrote had been present in either the people's minds or their criminal-justice practices. The slate of penalties for criminal deeds conveyed "no faint suggestion of a natural law of a life for a life," and in the areas of the law where death sentences appeared in their most non-negotiable form, the provisions in question seemed to have arisen out of "the theory of deterrence," not a "sense of natural justice." Morton's article clearly implied that in his eyes "this so called 'retributive justice"" deserved no higher status as an ally of capital punishment in the present than it had enjoyed among Britons of old. ${ }^{54}$

An abolitionist of greater clout used a similar approach to attack the appeal to justice. On February 7, 1965, interested members of the public gathered in Toronto to hear a talk by Thorsten Sellin, an American sociologist appearing at the invitation of the Canadian Society for the Abolition of the Death Penalty. At the time, perhaps no one in the world possessed a greater reputation than Sellin for expertise on capital punishment. ${ }^{55}$ He had captured the attention of the joint parliamentary committee investigating capital punishment in the mid-1950s, and various abolitionists referenced his work during parliamentary speeches in the following two decades. ${ }^{56}$ Among many other things, Sellin

\footnotetext{
${ }^{54}$ J.D. Morton, "Murder Most Foul," Canadian Bar Journal 2, no. 2 (April 1959): 115-117.

${ }^{55}$ See "Murderers 'Most Trusted Convicts,"' Toronto Daily Star, February 8, 1965, p. 17. According to this article, five hundred people attended the meeting.

${ }^{56}$ See Canada, Reports of the Joint Committee of the Senate and House of Commons on Capital and Corporal Punishment and Lotteries (Ottawa: Queen's Printer, 1956), 12-13. Sellin was mentioned in at least twenty-five speeches in the House of Commons between 1957 and 1976. For an example of great respect for his expertise, see House of Commons Debates (9 November 1967), 4104-4105 (John R. Matheson, MP - Liberal, Leeds, ON).
} 
had concerned himself with assessing how death-penalty law and the killing of police officers stood in relation to one another from a statistical perspective. In effect, his work suggested that to complete a career in policing without being murdered was just as easy when abolitionist policy prevailed as when authorities practiced a retentionist version of criminal justice. Such findings helped to put Sellin's work within the front ranks of abolitionist evidence, and facilitated claims that, from the perspective of the quest to deter homicide, capital punishment amounted to complete overkill, as it were. ${ }^{57}$ In his speech in Toronto, Sellin did devote substantial time to deterrence. However, although he disclaimed any expertise in ethical philosophy, he chose to examine retributive considerations first. In the eyes of some retentionists, he noted, the death penalty "possesses a certain moral fitness," provides what "simple justice demands," and constitutes the offender's "just deserts." Pointing to historical realities, Sellin attempted to disarm such retributive notions, claiming "that justice is a relative concept which changes with the times. A sense of justice must exist among all people to regulate their

\footnotetext{
${ }^{57}$ See Thorsten Sellin, "Capital Punishment: An Address Delivered at a Rally Sponsored by the Canadian Society for the Abolition of the Death Penalty, February 7, 1965," Criminal Law Quarterly 8, no. 1 (June 1965): 45-47. Copies of this speech were sent to MPs - see, for instance, LAC, MG32, Series C31 (Heath Nelson Macquarrie fonds), Volume 42, File 31 - File Title: "Capital Punishment. 1965," P.T. Matlow, National Secretary, The Canadian Society for the Abolition of the Death Penalty to all Members of the Canadian House of Commons and Senate, March 25, 1965, and the attached copy of the speech. A copy of the speech also appeared in Department of Christian Social Service, Anglican Church of Canada, The Death Penalty? (Toronto: Department of Christian Social Service, Anglican Church of Canada, n.d. [1965?]), 30-42. See also, for example, House of Commons Debates (28 March 1966), 3315 (Bryce Mackasey, MP - Liberal, Verdun, QC); (9 November 1967), 4089 (Andrew Brewin, MP - NDP, Greenwood, ON). See also Marvin E. Wolfgang, "Thorsten Sellin (26 October 1896 - 17 September 1994)," Proceedings of the American Philosophical Society 140, no. 4 (December 1996): 584. http://www.jstor.org/. Scholar Paul Friedland also uses the term "overkill" in the course of discussing past penal activity of a certain sort and people's perceptions of it; he refers to "a literal punitive overkill" Paul Friedland, "Beyond Deterrence: Cadavers, Effigies, Animals and the Logic of Executions in Premodern France," Historical Reflections/Réflexions Historiques 29, no. 2 (Summer 2003): 296.
} 
living together. This is an immutable requirement of social life, but what justice means is not immutable." Indeed, he suggested, some present-day nations considered retention, not abolition, to be a contravention of justice. ${ }^{58}$ Sellin's words implied what some other abolitionists also thought: at least in a retentionist context, to use the phrase "justice demands" was to employ a euphemistic substitute for "people demand," or "I demand." The retentionist appealing to this categorical version of justice wished to invoke an illusory transcendent principle as a way to avoid "accept[ing] the responsibility for his own ethics." 59

Skeptical comments about the transcendent or quasi-transcendent justice that some retentionists invoked did not constitute a major element of abolitionist discourse. Rather, observations of the type made by Sellin offered a possible line of argument that abolitionists could employ when they saw fit. One MP in the 1966 debate, for example, sang the same tune: "Through the centuries man has tried to grapple with the abstract question of justice. It is a relative concept which changes with the times." ${ }^{960}$ In the Canadian debate on the death penalty during this period, "justice" was largely a 38-39.

${ }^{58}$ See Sellin, "Capital Punishment: An Address," 36-51, especially 37-41. The quotations are from

${ }^{59}$ The quotation is an excerpt from the following sentence from a letter to the editor: "As for those who find justification in the Bible for capital punishment, they serve only to remind me that there is still much work to be done by liberal thinkers in the long struggle for a civilized world, and that mankind has still not yet accepted the responsibility for his own ethics" - Arthur W. Ghent, letter to the editor, Globe and Mail, February 27, 1960, p. 6. Although I have thus used the seven quoted words in a slightly different context than that in which they appear in the letter itself, the meaning I am drawing out seems fully in line with the letter.

${ }^{60}$ House of Commons Debates (5 April 1966), 3876 (Donald Ross Tolmie, MP - Liberal, Welland, ON). Along similar lines, see LAC, MG32, Series B27 (Marcel Lambert fonds), Volume 81, File 7 - File Title: "Capital Punishment 1966," The Canadian Society for the Abolition of the Death Penalty, Information Bulletin 2 (panel discussion held in the Confederation Room, Parliament Buildings [West Block] at Ottawa on Thursday, June 3, 1965) (Toronto: Canadian Society for the Abolition of the Death Penalty, 1965), 24, 29-30 (speech by René Lévesque and English translation of same). 
retentionist word, as we will see more clearly later in this chapter. Accordingly, abolitionists found it useful from time to time to cut the concept down to size.

However, Canadians who disliked retributive thought usually did so primarily for reasons other than a suspicion that the concept of justice lacked the transcendent, nonnegotiable status that some retentionists ascribed to it. For one thing, to those who respected opinion leaders, retributive thought smelled like something to avoid, or at least to handle warily. That, after all, is what the best and the brightest seemed to do. ${ }^{61}$ For example, John Howard Society leader A.M. Kirkpatrick told the mid-1950s joint parliamentary committee that "it is generally conceded that retribution should no longer assume a place in modern penology." ${ }^{92} \mathrm{He}$ could and did point to a strong Canadian precedent for this view. The 1938 Archambault Report, a major attempt at diagnosis and prescription with respect to the prison system, had indicated that "it is admitted by all the foremost students of penology that the revengeful or retributive character of punishment should be completely eliminated." ${ }^{93}$ Not all elites would have put it so strongly, but on the whole, those inclined to align their own thinking with that of opinion leaders had a prima facie reason to consider retribution undesirable, even before thinking the issue through for themselves.

\footnotetext{
${ }^{61}$ For evidence of this type of dynamic in American society during this period, see Banner, Death Penalty: An American History, 239-240, 282; see also David Garland, The Culture of Control: Crime and Social Order in Contemporary Society (Chicago: University of Chicago Press, 2001), 59.

${ }^{62}$ Canada, Joint Committee of the Senate and the House of Commons on Capital and Corporal Punishment and Lotteries, Minutes of Proceedings and Evidence, No. 14 (18-19 May 1954) (Ottawa: Queen's Printer, 1954), p. 596.

${ }^{63}$ Canada, Report of the Royal Commission to Investigate the Penal System of Canada (Ottawa: King's Printer, 1938), 9. Emphasis in original. Kirkpatrick quoted a passage from the report containing this quotation - see Canada, Joint Committee of the Senate and the House of Commons on Capital and Corporal Punishment and Lotteries, Minutes of Proceedings and Evidence, No. 14 (18-19 May 1954) (Ottawa: Queen's Printer, 1954), p. 596.
} 
For many Canadians, the retributive outlook appeared to point down a road diverging from the path indicated by Christianity, of which they considered compassion and forgiveness to be principal features. It has been observed that while Canadian churches saw a remarkable proportion of the populace come through their doors in the 1950s, many attendees showed neither devotional fervor nor strong doctrinal commitment. ${ }^{64}$ While this may well be true, those writing letters to the editor in the late 1950 s and early 1960 s do not appear to have been shy about discussing how religious teachings or ideals might recommend or discredit the death penalty. In the period 19571963, roughly a third of the letters on capital punishment that appeared in the Globe and Mail and a quarter of those in the Toronto Daily Star addressed some type of religious issue. $^{65}$ (By contrast, well under ten percent of capital-punishment letters in these two dailies in the $1970-1976$ period mentioned religious issues. ${ }^{66}$ ) Of the numerous letter-tothe-editor writers invoking religious ideas in the earlier years, a number suggested that Christianity, mercy, and non-retributivism formed a complementary trio. Some writers highlighted supposed contrasts between Christianity and earlier Hebrew religion. "The Mosaic code demands a life for a life," asserted one, "but the Christian code teaches forgiveness. ${ }^{\prime 67}$ Many suggested that Christ acted and spoke in ways demonstrating non-

\footnotetext{
${ }^{64}$ See Doug Owram, Born at the Right Time: A History of the Baby-Boom Generation (Toronto: University of Toronto Press, 1996), 103-109.

${ }^{65}$ However, note that this figure includes letters that criticized the attempt to discuss the death penalty by reference to religious beliefs.

${ }^{66}$ More precisely, fewer than six percent of the death-penalty letters in each of these two dailies mentioned religious issues during this latter period. These rough figures for the 1957-1963 and 1970-1976 periods are based upon the capital-punishment letters I identified using the search methodology noted in Chapter 1. There are probably additional letters in these two periods that I did not locate.

${ }^{67}$ George F. Allen, letter to the editor, Globe and Mail, January 28, 1960, p. 6. For other related examples, see (Rev.) Colin P. Clay, letter to the editor, Globe and Mail, January 5, 1960, p. 6; John E. Saul, letter to the editor, Toronto Daily Star, January 21, 1960, p. 6; Tom T. Rieder, letter to the editor, Globe
} 
retributivism. One writer, while endorsing retention, attacked E.L.H. Taylor's approach, declaring in the process that "Christ most emphatically rejected lex talionis." ${ }^{168}$ Others pointed out that forgiveness came from Christ's lips in the course of his own crucifixion: "Father, forgive them; for they know not what they do."69

No single theological or confessional camp monopolized such claims: those who presented Christianity, compassion, and abolition as a harmonious triad included a selfprofessed fundamentalist as well as writers of more liberal persuasion. ${ }^{70}$ Actually, the religion-mercy nexus did not surface only within the context of Christianity. For example, federal NDP leader David Lewis, himself a non-religious Jew, expressed sentiments probably shared by others: “All religions I have ever read of, all philosophical systems I have ever studied ... stress compassion, mercy and concern for every human being, even the wayward one, as a mark of decency and civilized behaviour.",71 Furthermore, some thought that religious mentalities and behaviours provided nothing essential to the pursuit of kindness, or that people would tend to live less compassionately

and Mail, February 1, 1960, p. 6.

${ }^{68}$ D.P. Wagner, letter to the editor, Globe and Mail, April 24, 1958, p. 6. See also W.C. Good, letter to the editor, Globe and Mail, April 24, 1958, p. 6; (Rev.) Hugh G. Crozier, letter to the editor, Globe and Mail, March 7, 1960, p. 6; Violet Sarty, letter to the editor, Globe and Mail, March 1, 1960, p. 6. The phrase "lex talionis" refers to the retributive principle that if there has been crime-generated damage to a victim, there should be punishment-generated damage of equal intensity to the victimizer. The idea is often articulated via the phrase "an eye for an eye" - Louis P. Pojman, "For the Death Penalty," 10, and Jeffrey Reiman, "Why the Death Penalty Should Be Abolished in America," 71-72, in Louis P. Pojman and Jeffrey Reiman, The Death Penalty: For and Against (Lanham, MD: Rowman \& Littlefield Publishers, 1998).

${ }^{69}$ Luke 23:34b (Revised Standard Version). See John E. Saul, letter to the editor, Globe and Mail, February 27, 1960, p. 6. See also James Rapson, Sr., letter to the editor, Globe and Mail, April 24, 1958, p. 6; Gordon Domm, letter to the editor, Toronto Daily Star, February 26, 1960, p. 6; Passerby, letter to the editor, Toronto Daily Star, February 18, 1961, p. 6.

${ }^{70}$ See Barrie G. Syme, letter to the editor, Toronto Daily Star, March 22, 1965, p. 6.

${ }^{71}$ House of Commons Debates (16 May 1973), 3847 (David Lewis, MP - NDP, York South, ON). See also Cameron Smith, Unfinished Journey: The Lewis Family (Toronto: Summerhill Press, 1989), $152,394-398$. 
when they adhered to Christianity. "Since when have Christians had a monopoly on forgiveness or any virtue or moral principle?" asked one letter writer in response to a certain retentionist. "Because we neither confirm nor deny the existence of a first cause, whom he calls God, he should not pretend we have no scruples."72 Indeed, it appears that the idea of abolition found readier acceptance among non-religious Canadians than among religious citizens. ${ }^{73}$

But despite the sometimes striking differences between even those writers who highlighted the compassionate character of religion, it is worthwhile to note that at least some of them tended to employ a progress-flavoured paradigm when thinking about human life and morality. One of the clearest examples is found in a speech by MP John Gilbert. Fellow parliamentarian Reg Stackhouse, whose résumé included experience in the Anglican ministry and on the faculty of Wycliffe College at the University of Toronto, had taken his stand with the retentionists in a speech to the House of Commons. ${ }^{74}$ Gilbert objected, claiming that Stackhouse had "tried to bring feelings of rage, passion and retribution to bear on the subject." Suggesting that Stackhouse's approach failed to jibe

\footnotetext{
${ }^{72}$ P. Carberry, letter to the editor, Globe and Mail, March 1, 1965, p. 6; see also Robert H. Parker, letter to the editor, Globe and Mail, September 3, 1962, p. 6.

${ }^{73}$ See Chandler, Capital Punishment in Canada, 62-63, 66; see Fattah, Study of a Social Attitude, $28-29,130$. Polling data provided in these two sources indicates that respondents who were not Protestant, Roman Catholic, or Jewish were substantially more inclined to support abolition than were Protestants or Catholics. It is less clear whether the non-Protestant/Catholic/Jewish citizens were more abolitionist than Jews - different polls differed, and as Chandler points out, only a small number of respondents were Jewish. I am assuming that the majority of the non-Protestant/Catholic/Jewish respondents probably espoused no religious faith, rather than a different religion. Chandler too interprets the data to mean that abolition found readiest acceptance among the non-religious.

${ }^{74}$ House of Commons Debates (23 July 1973), 5878-5879 (Reg Stackhouse, MP - Progressive Conservative, Scarborough East, ON). See Wayne Edmonstone, "Why an Anglican Priest is Running for Parliament," Toronto Daily Star, March 18, 1972, p. 66; see Reginald Stackhouse, The Way Forward: A History of Wycliffe College, Toronto, 1877-2002 ([Toronto: Wycliffe College?], 2002), 200-201, 323; see Tom Harpur, "Hell: Our Clergymen Take It Seriously," Toronto Daily Star, July 15, 1972, p. 23.
} 
even with Old Testament principles, Gilbert added:

I would have thought that the biblical scholar from Scarborough East would prefer to move from the Old Testament to the New Testament and adopt some of the teachings of the carpenter from Galilee. He taught that we should show forgiveness, understanding, compassion and love. But the hon. member did not dwell on those teachings. Does he not appreciate history, which shows mankind as moving from barbarism to enlightenment? ${ }^{75}$

Even if no one had been inclined to see value in compassion, some Canadians would still have found themselves conscious of the question marks tracing the basic but long-disputed boundaries of the ethical use of punishment. With pain of some sort, whether tangible or abstract, being an intrinsic ingredient of punishment, many people have thought that an authority who wishes to be ethically upright needs to be able to explain compellingly why he is making a guilty party feel the sting of the penalty in question, whatever that penalty might be. ${ }^{76}$ And execution was starkly tangible, not merely theoretically onerous. Many Canadians doubted that retributive claims qualified as the compelling explanation needed, at least in the case of sanctions as harsh as death. Abolitionists could judge the matter succinctly through a tried-and-true aphorism: "Two wrongs do not make a right." ${ }^{, 77}$ In his attack on the death penalty, one citizen wrote scornfully of "an archaic system of 'justice' that purports to correct a wrong by means of

\footnotetext{
${ }^{75}$ House of Commons Debates (23 July 1973), 5886 (John Gilbert, MP - NDP, Broadview, ON). For related examples, see House of Commons Debates (5 April 1966), 3867-3868 (Tommy Douglas, MP NDP, Burnaby-Coquitlam, BC); J.A. Davidson, "Christian Perspective on Death Penalty," Globe and Mail, January 6,1973, p. 7.

${ }^{76}$ See Ezzat Abdel Fattah, A Study of the Deterrent Effect of Capital Punishment with Special Reference to the Canadian Situation (Ottawa: Information Canada, 1972), 1; see Pojman, "For the Death Penalty," 5-6.

${ }^{77} \mathrm{G}$. Bedford, letter to the editor, Globe and Mail, December 6, 1962, p. 6. For similar examples, see J. Clarence Boyle, letter to the editor, Globe and Mail, February 18, 1960, p. 6; E. Rossiter, letter to the editor, Toronto Daily Star, December 11, 1964, p. 6; Angus McDowell Blair, letter to the editor, Toronto Daily Star, April 1, 1966, p. 6; Mrs. R. Flank, letter to the editor, Toronto Daily Star, February 23, 1973, p. 7.
} 
perpetrating another wrong." ${ }^{.78}$

Many who objected to retributive execution probably found it offensive mainly because it entailed stark injury and death, not simply because it brought retributive principles into play. But the coercion involved in retribution per se elicited philosophical opposition from a few citizens as well. One lawyer's rejoinder to an important advocate of retribution serves as a prime example. In January 1972 Chitty's Law Journal, a Peterborough-based publication, ${ }^{79}$ carried an article entitled "The Humanitarian Theory of Punishment," a product of the pen that the late author, English professor, and Christian apologist C.S. Lewis had wielded. In the two decades since the essay's original publication, it seems to have provided a sort of rallying point for those supportive of retributive punishment, turning up in a variety of publications in the English-speaking world ${ }^{80}$ The piece did not explicitly reveal Lewis' opinion on capital punishment, but he attacked the rehabilitative and deterrent penal vision - the "Humanitarian Theory of Punishment," to use his label — that British abolitionists had promoted. Lewis championed retribution and "the concept of Desert": only by deserving chastisement

\footnotetext{
${ }^{78}$ John S. Lynn, letter to the editor, Globe and Mail, December 29, 1962, p. 6.

${ }^{79}$ See the title pages of the January 1969 (volume 17, no. 1) and January 1973 (volume 21, no. 1) editions of Chitty's Law Journal.

${ }^{80}$ See C.S. Lewis, "The Humanitarian Theory of Punishment," The Canadian Intelligence Service (Flesherton, ON) 15, no. 3 (March 1965): Supplementary Section, p. 1-4, located in LAC, MG32, Series C31 (Heath Nelson Macquarrie fonds), Volume 42, File 31 - File Title: "Capital Punishment. 1965." The piece was also the first essay in T. Robert Ingram, ed., Essays on the Death Penalty (1963; repr., Houston, TX: St. Thomas Press, 1971), 1-12, and it was included in C.S. Lewis, God in the Dock: Essays on Theology and Ethics, ed. Walter Hooper (Grand Rapids, Michigan: William B. Eerdmans Publishing Company, 1970), 287-294. For references to two other periodicals in which it was published, including the journal publishing it originally in 1949, see p. 16-17 in God in the Dock. Note also the citing of the essay in Taylor, "Retribution, Responsibility and Freedom," 56, and the citing of a Lewis essay (probably the same one - cf. Garland, Culture of Control, 232 n. 27) in G.F. Atkinson, letter to the editor, Globe and Mail, July 29, 1966, p. 6.
} 
could a person become a candidate for ethically sound punishment. Although he did not acknowledge it, in essence Lewis focused not on proving that punishment should proceed if desert existed, but on showing that it should not proceed if desert were not present. By denying the state the use of unmerited penalties, "the concept of Desert" helped to ensure that the penal system would not slide into Stalinesque mode, as Lewis thought it might if authorities decided to reorient their approach and to let nothing bar the way to deterrent or rehabilitative success. ${ }^{81}$

Lewis' essay provoked an extended letter to the editor in the June 1972 edition of the law journal. W.H. Hurlburt, a Queen's Counsel from Edmonton, believed that penalties could not be ethical unless they owed their existence to authorities' efforts to ensure "protection of ... society and of the individuals who compose it." Such efforts fell "within the morality of self-defence." By contrast, those who wished to identify some other factor of sufficient weight to give the go-ahead for punishment were out of luck: desert could not fill the bill. "Society," wrote Hurlburt, "should not ... inflict a penalty on an individual merely because that individual deserves it, i.e., because he does not conform to a certain moral standard." Hurlburt also seems to have been less inclined than Lewis to associate the idea of desert with a single moral reality pertinent to human existence. "It is wrong," Hurlburt declared, "for an individual to punish merely because he thinks that another deserves to be punished. It is equally wrong for a group of individuals organized in a political state to punish merely because they think that an individual deserves to be

\footnotetext{
${ }^{81}$ C.S. Lewis, "The Humanitarian Theory of Punishmenat," Chitty's Law Journal 20, no. 1 (January 1972): 1-5.
} 
punished." Desert-centred punishment, Hurlburt implied, remained too closely related to "us[ing] the force of the state to impose my ideas of morality on others," which would itself be "immoral." Furthermore, Hurlburt pointed out that, pace Lewis, a nation that employed punishment to "defend itself" remained quite able to keep its penal efforts in check and avoid "inflicting penalties which are out of proportion to the seriousness of the prohibited conduct." In short, focusing on "protection" and "self-defence" would permit society to maintain a chill on lawlessness, to avoid the draconian penal system that Lewis feared, and to avoid the coercive overkill that would result from using the hermeneutic of moral desert to interpret penal affairs. ${ }^{82}$

Occasionally abolitionist MPs speaking on the death penalty voiced perspectives that, like Hurlburt's letter, displayed a particularly clear affinity for the anti-coercive ethos of liberalism. "None of us is here to impose harsher restrictions on life," stated one parliamentarian to his fellows. Preferably, "everyone" would "be free to pursue the course he deems best for him. It is only when people behave in such a way that is a menace to the happiness and well-being of their fellow citizens that the state has the right to intervene," and "there must be as little force as necessary to ensure the public safety." Retributive execution, and even retributive punishment per se, seemed out of line with such criteria.

\footnotetext{
${ }^{82}$ W.H. Hurlburt, letter to the editor, Chitty's Law Journal 20, no. 6 (June 1972): 181-183. As noted earlier, scholar Paul Friedland also uses the term "overkill" in the course of discussing past penal activity of a certain sort and people's perceptions of it; he refers to "a literal punitive overkill" - Friedland, "Beyond Deterrence," 296.

${ }^{83}$ House of Commons Debates (29 January 1973), 727 (Peter Reilly, MP - Progressive Conservative, Ottawa West, ON). For a related example, see House of Commons Debates (14 May 1973), 3720-3721 (Norman Cafik, MP - Liberal, Ontario, ON).
} 
Why did retentionists who spoke from a retributive vantage point not buy into the criticism of the abolitionists who drew attention to the violent injury or fundamental . coercion seemingly bound up with retributive execution? As the case of E.L.H. Taylor demonstrates, many retributivists found reassurance by looking to the ideal of justice. But Taylor's views even more clearly illustrate the affinity between retributivism and the religious outlook of many retentionists. When Taylor contemplated the theological and metaphysical realities that he believed to be bound up with the crucifixion of Christ, retributive principles formed part of the picture that he saw. Through the crucifixion, Christ "reconciled law and love, by His love vindicating law. As our great High Priest, He paid homage to the sanctity of the Moral Order by Himself paying the price of sin. Thereby His love broke through the demands of law by satisfying its every requirement." ${ }^{84}$ To Taylor, the abolitionist movement and its anti-retributive viewpoints would help to put Canadian thought patterns, especially the ones predominant in public discourse, further out of tune with a truly Christian mentality. Abolition constituted "a secular revolution in Christian disguise," as the title of one of his articles put it. ${ }^{85}$ Taylor could portray death sentences for murderers as being what "justice herself requires," ${ }^{86}$ but his strong belief in acknowledging this requirement stemmed from his confidence that justice occupied a role which God himself had affirmed.

\footnotetext{
${ }^{84}$ E.L.H. Taylor, "Christ's Interpretation of His Own Death," His Dominion 10, no. 2 (May 1, 1961): 23; see also 22. See also Taylor, New Legality, 18-20. For an abolitionist statement that opposed this understanding of the crucifixion, see LAC, MG32, Series B27 (Marcel Lambert fonds), Volume 81, File 13 - File Title: "Capital Punishment 1976 file 1," "The New and the Old," ("Sermon preached Sunday, February 29, 1976 a.m. by the Rev. A.J. Farquhar, First-St. Andrew's United Church, London, Ontario, Canada").

${ }^{85}$ Taylor, "A Secular Revolution in Christian Disguise."

${ }^{86}$ (Rev.) E.L.H. Taylor, letter to the editor, Globe and Mail, April 18, 1958, p. 6.
} 
Admittedly, many retentionists who appealed to justice drew no explicit links between justice and Christian beliefs. Some writers invoked the idea without elaborating on the conceptual makeup of justice. ${ }^{87}$ One retentionist who did analyze the nature of justice in detail (without linking it to religious revelation) painted it in less transcendent, metaphysical colours, emphasizing instead the esteem that a conservative version of justice had earned in the historical long term, and commending its alleged capacity to deal with offender and offended in a balanced manner. ${ }^{88}$ On the other hand, at least on rare occasions a non-Christian letter writer did encourage his audience to think of justice or retribution as tied to essentially transcendent phenomena, although such writers did not necessarily support the death penalty. ${ }^{89}$

However, the retributive vision of justice and punishment found an especially striking degree of support among conservative Christians. Evangelical and fundamentalist Protestants spoke their mind particularly adamantly, and at least some conservative Catholics also believed that consideration of God's deeds and directives would make objections to retributive punishment unimpressive. "[T]he authorities have the right and the duty to punish the bad and reward the good," declared one MP. "God

\footnotetext{
${ }^{87}$ See, for example, (Miss) M. Ray, letter to the editor, Toronto Daily Star, February 7, 1966, p. 6; L.S. Rolko, letter to the editor, Toronto Daily Star, February 6, 1973, p. 7; C. Douglas Sayles, letter to the editor, Globe and Mail, March 4, 1976, p. 6; Gerard Scully, letter to the editor, Toronto Daily Star, March 6, 1976, p. B3.

${ }^{88}$ See LAC, MG32, Series B27 (Marcel Lambert fonds), Volume 82, File 1 - File Title: "Capital Punishment 1976 file 3," "Brief Prepared By: Mr. Woodburn Thompson," p. 59-69 in spiral-bound "To the Parliamentary Committee on Justice and Legal Affairs, Capital Punishment, Bill C-84, Submissions Presented by the National Police Committee for the Protection of the Citizens" (attached to May 10, 1976 covering letter).

${ }^{89}$ See T.B.G. Burch, letter to the editor, Globe and Mail, February 21, 1958, p. 6; Bruce Quan, letter to the editor, Globe and Mail, April 5, 1960, p. 6. The former letter did not address capital punishment; the latter argued against the death penalty.
} 
Himself does it in this world and in the next. As all power comes from God, the authorities should imitate God: they should punish evil while tempering justice with mercy." In the end, "[j]ustice must be done, it must triumph according to natural law and divine law." In the eyes of another retentionist, to murder was to contravene "an immutable law" that "carries with it a penalty ... exacted by divine justice."91 Many retentionists had the Bible on their minds. One Globe reader, having spent most of his letter discussing biblical content and attendant theology, concluded by stating that "[t]he death penalty is never referred to as a deterrent; it was, is, and should remain, punishment." Many of those who saw a firmly retentionist message in Scripture probably did not consider retribution to be the sole penal dynamic involved in the death penalty, but they still perceived little weight in anti-retributive arguments. "Our opinions," declared one, "should have no bearing on capital punishment any more than they have on the Ten Commandments."93

If a number of evangelical Christians displayed especially strong support for penal retribution, leaders within the larger Christian bodies also sometimes gave serious

\footnotetext{
${ }^{90}$ House of Commons Debates (5 April 1966), 3897, 3898-3899 (Henri Latulippe, MP Ralliement Créditiste, Compton-Frontenac, QC).

${ }^{91}$ House of Commons Debates (24 May 1973), 4083 (Jake Epp, MP - Progressive Conservative, Provencher, MB). For a particularly noteworthy example of an evangelical or fundamentalist intensely supportive of retributive justice, see the letters to the editor by Arthur Durnan in the Toronto Daily Star on June 19, 1964, p. 4; December 11, 1964, p. 6 [although the surname given here is "Durnam," the home community of the writer and the content of the letter make it virtually certain that it is Arthur Durnan]; February 3, 1966, p. 6; January 28, 1970, p. 7; November 16, 1972, p. 7; December 8, 1972, p. 7. See also Rev. Arthur Durnan, "Metro Evangelist Says Capital Punishment Is Christian," Toronto Daily Star, February 14, 1970, p. 79.

${ }_{92}^{92}$ E. Leonard Watson, letter to the editor, Globe and Mail, February 16, 1960, p. 6.

${ }^{93}$ G. Black, letter to the editor, Globe and Mail, April 28, 1958, p. 6. See also, for example, David M. Duncan, letter to the editor, Globe and Mail, January 28, 1960, p. 6; Robert B. Liddell, letter to the editor, Globe and Mail, March 7, 1960, p. 6; W. Zuhajewicz, letter to the editor, Globe and Mail, March 10, 1960, p. 6.
} 
consideration, if not necessarily support, to retributive perspectives. The major churches in Canada appear to have looked upon the death penalty in much the same way as their counterpart bodies on the other two corners of the North Atlantic Triangle. In Great Britain, for instance, the Church of England began to advance the abolitionist point of view in the 1950s after long having largely impeded it. ${ }^{94}$ In the United States, abolitionism began to receive collective praise from the Catholic bishops in the 1970s. Similarly, between the mid-1950s and the mid-1970s, the United Church of Canada, Anglican Church, and Presbyterian Church — in that order - for the first time indicated themselves to be of abolitionist mind. The Canadian Catholic Conference all but did the same in $1973 .^{95}$ Examining a few of the assessments of retribution that emerged from Canadian Catholic and mainline Protestant sources between the mid-1950s and the mid1970s provides a taste both of the ambivalence that mainstream Christian thinkers felt about the issue and of the basis on which they concluded that Christians should not allow retributive thought to steer them into the retentionist camp.

The Anglican Church of Canada made its pro-abolition decision in $1958 .{ }^{96}$ In the two years preceding this decision, Church members could avail themselves of recent printed material through which the denomination's Council for Social Service hoped to

\footnotetext{
${ }^{94}$ See Harry Potter, Hanging in Judgment: Religion and the Death Penalty in England from the Bloody Code to Abolition (London: SCM Press Ltd., 1993), vii, 204-207.

${ }^{95}$ While the 1973 statement of the Canadian Catholic Conference was not committal, it strongly implied that Canada should at least stay the course with the near-abolitionist sentencing law that had emerged in 1967. See Megivern, Historical and Theological Survey, 321-322, 344, 352-353, and chapter 9 as a whole; see also Melton, The Churches Speak on: Capital Punishment, 2-3, 129-131; see also Department of Christian Social Service, Anglican Church of Canada, The Death Penalty?, 5-6.

${ }^{96}$ There was roughly a 3-to-2 abolitionist-to-retentionist ratio in the vote by which the Executive Council of the General Synod ratified an abolitionist statement. See F.H. Wilkinson, "Man Given Right to Take Life," Globe and Mail, March 5, 1960, p. 8; see also Department of Christian Social Service, Anglican Church of Canada, The Death Penalty?, 5-6.
} 
make the essence of the controversy clear. One 1956 document, "The Ethics of Punishment," contained an essay composed a quarter-century earlier by William Temple, who had later become Archbishop of Canterbury. ${ }^{97}$ While Temple stood with the abolitionists, he also counted himself a supporter of retribution, in a sense. But the retribution that he strongly affirmed did not, as for Taylor, consist in an offender's experiencing penal consequences "to restore the just order which he has made unstable." Indeed, to Temple, "the word retribution suggests the mere balancing of an ill deed by equal pain or inconvenience, of allotting so much suffering to so much sin, and in that I can see no good whatever." Instead, retributive dynamics achieved ethical merit in "express[ing] the repudiation of the crime by the community." 99 In short, Temple espoused a version of retribution that would also receive at least the partial approval of many future abolitionists. Like the latter group, Temple appears to have believed that the denunciation of murder through penalization would retain equal clarity, and even gain superior clarity, following a shift from the death penalty to a non-lethal sanction. ${ }^{100}$ Temple did believe in a transcendent "moral order," and he probably believed that the "standard which must be upheld" through penal denunciation should generally correspond

\footnotetext{
${ }^{97}$ William Temple, "The Ethics of Punishment: A (Reprint)," The Bulletin (The Council for Social Service, The Anglican Church of Canada) No. 165 (October 15, 1956), located in LAC, MG32, Series B1 (Richard Albert Bell fonds), Volume 38, File 1 - File Title: "Capital Punishment 1955-60." See also the introduction to this document. See also Potter, Hanging in Judgment, 142, 284.

${ }_{98}$ Taylor, "Secular Revolution," 43.

99 Temple, "Ethics of Punishment," 2, 3.

${ }^{100}$ See ibid., 4; see House of Commons Debates (9 November 1967), 4080 (Larry Pennell, MP Liberal, Brant-Haldimand, ON); (3 May 1976), 13090-13091 (Warren Allmand, MP - Liberal, NotreDame-de-Grâce, QC); (15 June 1976), 14497-14498 (Ed Broadbent, MP - NDP, Oshawa-Whitby, ON); LAC, MG32, Series C31 (Heath Nelson Macquarrie fonds), Volume 43, File 7 - File Title: "Capital Punishment 1985-1987," "Capital Punishment: Policy Statement of the Canadian Association of Social Workers." These later abolitionists thought about retribution along similar lines, though not always and in all respects as wholeheartedly as Temple.
} 
to what God had revealed to humanity. ${ }^{101}$ But the general type of retribution that he promoted remained satisfying to many others who pictured the genesis of moral values differently.

When the Council for Social Service printed the Temple essay in 1956, extensive quotations from the essay had already appeared in a 1955 Anglican document that provided retentionist and abolitionist arguments crafted by two current Canadian clergymen. Leonard Hatfield, the abolitionist writer, made ample use of Temple's thoughts on retribution. ${ }^{102}$ Ironically, the proponent of retention, T.F. Summerhayes, seemed more reluctant than Temple to discuss retribution. To Summerhayes, a long-time retentionist, "[t]he deterrent effect.... is the most important element in the whole matter." This is not to say that considerations of justice held no appeal for him. But he approached the latter issue somewhat guardedly, asking, for instance:

If ... the murderer is not to be executed, but to be imprisoned for life (or less), the result would be that the criminal would be housed, fed, clothed, educated, amused, for life at the expense of the State, whereas the wife and family of the murdered policeman (or other citizen) have nothing done for them. Is this just or right?

Summerhayes wrote only briefly and "with diffidence" about the relationship between the controversy and expressly religious norms, offering in the process a few Scripture passages that apparently revealed "the sterner side of the Christian Religion."103

\footnotetext{
${ }^{101}$ See Temple, "Ethics of Punishment," $1,3$.

${ }^{102}$ See L.F. Hatfield, "A Study of Capital Punishment," The Bulletin (Council for Social Service, The Church of England in Canada) No. 163 (January 10, 1955): 5-15, especially 5-6, 9-13. A copy of this document is found in LAC, MG26, Series N2 (Lester B. Pearson fonds - Leader of the Opposition), Volume 37, File 425 - File Title: "Capital Punishment."

${ }^{103}$ T.F. Summerhayes, "Capital Punishment for Murder," The Bulletin (Council for Social Service, The Church of England in Canada) No. 163 (January 10, 1955): 2-4, located in LAC, MG26, Series N2 (Lester B. Pearson fonds - Leader of the Opposition), Volume 37, File 425 - File Title: "Capital
} 
Summerhayes' hesitance in discussing retributive issues and Anglican abolitionists' acceptance of Temple's treatment of retribution illustrate both how compelling retributive thought continued to be and how little credibility people perceived in the more thoroughgoing forms of retributivism, such as the kind promoted by Taylor.

Although Catholic leaders tended to call attention to the common good and the practical repercussions of abolition or retention, they also considered retributivist claims. One figure to do so was Father John Kelly, a long-time servant of St. Michael's College as a faculty member and then as president. ${ }^{104}$ Kelly put in his word for abolition on more than one occasion. ${ }^{105}$ On January 29,1966 , he shared his thoughts with the Canadian Society for the Abolition of the Death Penalty. While his speech did not draw nearly the size of crowd that Sellin's had, it did catch the attention of parliamentarians. ${ }^{106}$ Kelly sought partly to refute the outlook of "the die-hard retentionists" who in the end would remain retentionist "on ... retributive grounds alone." Among other things, Kelly pointed

Punishment." The quotations are from pages 2 and 3. A substantial amount of correspondence from Summerhayes to Lester Pearson on the death-penalty issue can be found in this same file in the Lester B. Pearson fonds. Summerhayes also sent letters to the editor of the Globe and Mail; see the issues for December 6, 1958; December 24, 1958; and October 8, 1959.

${ }^{104}$ See Dictionary of Basilian Biography: Lives of Members of the Congregation of Priests of Saint Basil from Its Origins in 1822 to 2002, Second Edition, Revised and augmented by P. Wallace Platt (Toronto: University of Toronto Press, 2005), s.v. "Kelly, John Michael."

${ }^{105}$ See "The Abolition of Capital Punishment," Canadian Bar Review 32, no. 5 (May 1954): 485, 502-505. The latter four pages record a speech Kelly made at a Canadian Bar Association gathering for the Ontario region. See also Pullen, Arthur Maloney, 208-209.

${ }^{106}$ Toronto Daily Star, "Hanging Abolitionists Warned Work Hard, You Could Lose," January 31, 1966, p. 21. According to this article, 62 people were on hand to hear Kelly. Copies of the speech were later provided to MPs. For MPs' references to the speech, see House of Commons Debates (24 March 1966), 3105-3106 (Gordon Fairweather, MP - Progressive Conservative, Royal, NB); (24 March 1966), 3124 (Réal Caouette, MP - Ralliement Créditiste, Villeneuve, QC); (24 March 1966), 3148-3149 (John Gilbert, MP - NDP, Broadview, ON); (24 March 1966), 3151 (Joseph O'Keefe, MP - Liberal, St. John's East, NF). For other references to Kelly that probably pertain to this speech, see House of Commons Debates (28 March 1966), 3292 (C.-A. Gauthier, MP - Ralliement Créditiste, Roberval, QC); (14 November 1967), 4253 (John Turner, MP - Liberal, St. Lawrence-St. George, QC). 
to Aquinas, who had suggested "that in this life punishment should be medicinal rather than retributive."107 Aquinas' overall vision of punishment had actually included retributive considerations to a greater degree than those listening to Kelly's speech might have gathered. ${ }^{108}$ But in noting Aquinas' belief "that human punishments are not to be sought solely for their own sake because this world is not the place of ultimate redress," Kelly raised a key issue also discussed by another Canadian Catholic abolitionist. ${ }^{109}$ God does indeed maintain retributive justice, Gordon George suggested, but not necessarily in the temporal and spatial context of present human life, and people should not become too enthusiastic about trying to bring retribution into play on this side of the grave. ${ }^{110}$ Scholar James Megivern has portrayed the abolitionist perspective emerging strongly among Catholic leaders in the second half of the twentieth century as involving "a retrieval of" a type of mind-set and pattern of sentiments that would mesh with Christianity in its virgin form. Although Megivern does not hold out abolitionists' interpretation of Aquinas as a main component of this "retrieval," Canadian Catholic

${ }^{107}$ The quoted words are Kelly's. See LAC, MG32, Series B11 (E. Davie Fulton fonds), Volume 130, File Title: "Capital Punishment 1965-1966 Vol. 1," Rev. J.M. Kelly, C.S.B., "Address to the Canadian Society for the Abolition of the Death Penalty," January 29, 1966, p. 5 [3], 7 [4]. This copy of the speech appears to be a typed transcription of an original copy, with two pages of text from the original being placed on each page of this transcription. The original page numbers are marked within the text, while the transcription is not itself paginated. The numbers I have given in brackets are the real (but unmarked) page numbers of the transcription. Only the original page numbers are used in subsequent notes.

${ }^{108}$ See Megivern, Historical and Theological Survey, 112-115.

${ }^{109}$ The quoted words are Kelly's. See LAC, MG32, Series B11 (E. Davie Fulton fonds), Volume 130, File Title: "Capital Punishment 1965-1966 Vol. 1," Rev. J.M. Kelly, C.S.B., "Address to the Canadian Society for the Abolition of the Death Penalty," January 29, 1966, p. 7.

${ }^{110}$ See Gordon F. George, "Final Justice Up to Creator," Globe and Mail, March 5, 1960, p. 8. For another discussion with partial similarities to George's, see LAC, MG32, Series B35 (Walter Gilbert Dinsdale fonds), Volume 79, File 5 - File Title: "Capital Punishment. General. Feb.-July 1976," transcript of 25 May 1976 meeting for parliamentarians in Railway Committee Room with panel of speakers sponsored by Canadian Society for the Abolition of the Death Penalty, pp. 16-17 (speech by Bishop Emmett Carter). See also Megivern, Historical and Theological Survey, 114-115. 
abolitionists" outlook on retribution might fit with the "recovery" model in a broad sense, insofar as they called on ideas also advanced by a central intellectual figure of traditional Catholicism. However, Megivern also acknowledges that new mentalities which blossomed into potent form in the postwar decades provided crucial ingredients as well in the changing Catholic viewpoint on the death penalty. ${ }^{111}$ This latter phenomenon certainly obtained north of the forty-ninth parallel. The abolitionists may have wanted to offer rationales compatible with long-past precedents, but they also drew attention to the parallels between their viewpoint and the thought patterns prevailing within their own era. Kelly was not one to embrace all new perspectives and discard all old ones. ${ }^{112}$ But while discussing the notion of "[t]he die-hard retentionist" "that inflicting suffering on an offender is justified in itself, an end in itself, regardless of the consequences whether they be good or bad," Kelly stated: "The modern conscience rejects this and I think that on this point the modern conscience is right." $" 113$

In his 1975 essay "Theology and the Death Penalty," Father Thomas Dailey, a professor at St. Augustine Seminary and the Toronto School of Theology, painted abolition in the colours of the present to a much more striking degree. Admittedly, since Dailey wrote this essay on behalf of a multidenominational abolitionist committee, and

${ }^{111}$ See Megivern, Historical and Theological Survey, 1-5, 38, 42-45, 250, 259, 286, 291, 340-342, $377,394,396,457-458$. See 377 for the quote. It should be noted that Catholic leaders' abolitionism generally involves the claim that certain types of settings and exigencies can, in light of the nature of rightful state authority, make moral space for capital punishment, but that such contexts do not presently exist in the Western world. See Megivern, Historical and Theological Survey, 392-395, 444-445.

${ }^{112}$ Note, for instance, his comments about natural law and positive law, as well as the general tone of his discussion, in John Kelly, "Love All Men as We Love Ourselves," Gazette (The Law Society of Upper Canada) 9, no. 4 (December 1975): 291-296, especially 295.

${ }^{113}$ LAC, MG32, Series B11 (E. Davie Fulton fonds), Volume 130, File Title: "Capital Punishment 1965-1966 Vol. 1," Rev. J.M. Kelly, C.S.B., "Address to the Canadian Society for the Abolition of the Death Penalty," January 29, 1966, p. 5. 
since the piece sought to provide evidence of widespread abolition-friendly thinking among theologians, it may not perfectly reveal his own precise pattern of reasoning. ${ }^{114}$ In any case, he characterized Christian thinkers of the early and later eras alike as at least moderately retentionist. He wished, however, to correct "the impression that theology is committed to the retention of the death penalty in modern times." Dailey observed that retributivism "is today under heavy fire.... Is a physical punishment considered as such, really a means of balancing the disturbed equilibrium of justice?" "[S]ome theologians," he noted, "... regard the concept of retributive justice as insufficiently purged of atavistic notions of vendetta to be acceptable." Borrowing a phrase from Karl Menninger, he described "the retribution theory" as "the pursuit of "primitive people wreaking vengeance on a ritual victim."'115 While Dailey thus associated retributivism with a past that he thought should find no imitators among modern societies, his paper also

\footnotetext{
${ }^{114}$ LAC, MG32, Series C26 (Francis Andrew Brewin fonds), Volume 45, File 17 - File Title: "Capital Punishment 1975-1976 File 2," Thomas G. Dailey, "Theology and the Death Penalty." It appears that this essay was mailed to all MPs, and it also appeared in an Anglican Church periodical publication. See LAC, MG32, Series C26 (Francis Andrew Brewin fonds), Volume 45, File 17 - File Title: "Capital Punishment 1975-1976 File 2," W. Clarke MacDonald to Members of the Senate and the House of Commons, April 22, 1975, and G. Russell Hatton to Andrew Brewin, May 20, 1975; see also Thomas Dailey, "Theology and the Death Penalty," The Inkhorn 2:2 (Spring/Summer 1975): 1-8, located in LAC, MG32-B35 (Walter Gilbert Dinsdale fonds), Volume 79, File 5 - File Title: "Capital Punishment. General. Feb.-July 1976." It also appears that, as of April 1975, four church denominations and the John Howard Society either planned to or were in the process of making the essay available to their members or "publishing it through their church press." I do not know whether this wide distribution actually ended up occurring. See LAC, MG28, Series 1327 (Canadian Council of Churches fonds), Volume 39, File 22 - File Title: "Commission on Canadian Affairs Minutes - Task Force on the Abolition of Capital Punishment, 1975-1976," Minutes - Task Force on Capital Punishment, Canadian Council of Churches, Tuesday, April 8,1975 . See also, in the same file, the minutes for the same task force for January 15, 1975 (p. 2), March 13, 1975 (p. 3), and May 15, 1975 (p. 1-2).

${ }^{115}$ LAC, MG32, Series C26 (Francis Andrew Brewin fonds), Volume 45, File 17 - File Title: "Capital Punishment 1975-1976 File 2," Thomas G. Dailey, "Theology and the Death Penalty," p. 2-4. The Menninger book that Dailey was quoting was Karl Menninger, The Crime of Punishment (New York: The Viking Press, 1968), 108 - see Thomas Dailey, "Theology and the Death Penalty," The Inkhorn 2:2 (Spring/Summer 1975): 7 n. 9, located in LAC, MG32-B35 (Walter Gilbert Dinsdale fonds), Volume 79, File 5-File Title: "Capital Punishment. General. Feb.-July 1976."
} 
repeatedly linked abolition with the present. As Dailey shared his own thoughts and summarized or quoted other scholars, abolition found allies in "today's heightened awareness of the value of human life," in "contemporary theological awareness," and in "'a dynamic and developing view of man." Christian leaders "[i]n recent years," "today," and "now" wished to see the elimination of capital punishment. ${ }^{116}$ In sum, like many other abolitionists, various Canadian religious leaders believed that to activate retribution in its own right was probably to cross the frontier into wrong, and they sensed that, whatever may have been true of the past, retributive notions would find ever-fewer respectable friends in the present and future. ${ }^{117}$

Many Canadians probably cared neither so much as W.H. Hurlburt about the coercive implications of retributive punishment nor so much as clergymen about various theological particulars. However, when Hurlburt associated ethical punishment with selfdefence, he was advancing a view that a wider portion of the public would have considered persuasive. Rarely if ever did a participant in the death-penalty debate claim that people ought to avoid hurting others even when such restraint entailed exposing themselves to substantial injury at the hands of an antagonist. As one abolitionist stated, "Man clearly has the right to protect himself by using any means that is essential to do

\footnotetext{
${ }^{116} \mathrm{LAC}, \mathrm{MG} 32$, Series C26 (Francis Andrew Brewin fonds), Volume 45, File 17 - File Title: "Capital Punishment 1975-1976 File 2," Thomas G. Dailey, "Theology and the Death Penalty," p. 2, 7, 8. The phrase "'a dynamic and developing view of man" was part of a quotation of a statement by Georgetown University's Dr. Warren Reich - the endnote to this statement in Dailey's essay reads "Quoted in an interview in National Catholic Reporter, April 6, 1973, p. 21" - see Thomas Dailey, "Theology and the Death Penalty," The Inkhorn 2:2 (Spring/Summer 1975): 8, located in LAC, MG32-B35 (Walter Gilbert Dinsdale fonds), Volume 79, File 5 - File Title: "Capital Punishment. General. Feb.-July 1976."

${ }^{117}$ For an observation similar to mine, see Sellin, "Capital Punishment: An Address," 41. On retributivism and what was "respectable," see also Gowers, Life for a Life?, 135-136; Banner, The Death Penalty: An American History, 282.
} 
so," including killing, "if it were absolutely essential." And such "would also be true of the state" were this "the only course it could follow in order to achieve its essential objective of protecting society."118 But if nearly everyone thought well of self-defence and of punishment comparable thereto, some abolitionists who contemplated whether lethal sanctions might intersect with notions of self-defence insisted that such purported penal self-defence must take place only if known to be genuine. "[W]e are only justified in taking another life when it is the last resort in self-defence," declared Solicitor General Warren Allmand. "It is clear that capital punishment is not the last resort in selfdefence."119 And having thus identified a principle that encompassed the type of hypothetical scenario in which they would brook the idea of execution, such abolitionists had no interest in assessing the death penalty from a retributive vantage point. Executing an offender "in the name of justice ... is decidedly wrong," argued one MP, for "there is no justification save self-defence for the taking of a human life under any circumstances." 120

The appeal of self-defence as a penal concept extended beyond the abolitionist camp: retentionists used the idea too. ${ }^{121}$ Even some retentionists who saw value in retributive conceptions were happy to introduce the highly regarded concept of self-

\footnotetext{
${ }^{118}$ House of Commons Debates (14 May 1973), 3720 (Norman Cafik, MP - Liberal, Ontario, ON).

${ }^{119}$ House of Commons Debates (26 January 1973), 689 (Warren Allmand, MP - Liberal, NotreDame-de-Grâce, QC).

${ }^{120}$ House of Commons Debates (31 January 1973), 844 (Terry O'Connor, MP - Progressive Conservative, Halton, $\mathrm{ON}$ ).

${ }^{121}$ See, for example, House of Commons Debates (25 February 1960), 1468-1470 (J.W. Kucherepa, MP - Progressive Conservative, High Park, ON); House of Commons Debates (15 June 1976), 14503-14506 (Steven Paproski, MP - Progressive Conservative, Edmonton Centre, AB).
} 
defence into their account of why the death penalty should live to see another day. ${ }^{122} \mathrm{~A}$ statement made by Leonard Hatfield in 1955 probably conveys a good sense of the collective outlook on retribution during much of the period of the present study: "There is today in the public mind an uneasiness as to whether one crime justifies its legalized equivalent. It is recognized that murder is wrong, but does a second wrong accomplish anything positive?"123 Various Canadians thought, whether consciously or not, that their "uneasiness" would be assuaged when self-defence came into play. ${ }^{124}$ And when debaters needed to determine whether the practice of executing murderers intersected with intelligent efforts of "collective self-defence," deterrence became a natural topic to discuss. $^{125}$

As much as making offenders taste this "second wrong" may have created "uneasiness" in Canadians' psyches, perhaps abolitionists made the greatest headway in their fight against retributive claims when they criticized revenge. In many abolitionists' eyes, describing retribution as revenge amounted to calling a spade a spade. When Taylor commended retribution in the Globe and Mail, one opponent countered that

\footnotetext{
${ }^{122}$ See, for example, House of Commons Debates (23 May 1973), 4024-4025 (John Wise, MP Progressive Conservative, Elgin, ON); House of Commons Debates (24 March 1966), 3150-3153 (Joseph O'Keefe, MP - Liberal, St. John's East, NF).

${ }^{123}$ Hatfield, "A Study of Capital Punishment," 12. Perhaps the following comment by one retentionist citizen reflects this cultural "uneasiness" about retribution and "punishment": "The name, Capital Punishment should perhaps be changed to Operation Destiny - or Sacrifice Salutary to Society or something omitting the word punishment" - see LAC, MG32, Series B11 (E. Davie Fulton fonds), Volume 130, File Title: "Capital Punishment 1965-1966 Vol. 1," Georgina Harrison to Mr. Fulton, March 1966.

${ }^{124}$ For an example that perhaps suggests this type of dynamic, see House of Commons Debates (30 January 1973), $782-784$ (Gaston Clermont, MP - Liberal, Gatineau, QC).

${ }^{125}$ The quotation is from House of Commons Debates (15 June 1976), 14500 (Pierre Trudeau). See also House of Commons Debates (5 May 1976), 13220 (Ursula Appolloni, MP - Liberal, York South, ON); House of Commons Debates (15 June 1976), 14496-14498 (Ed Broadbent, MP - NDP, OshawaWhitby, ON).
} 
"' $\mathrm{r}]$ etribution" is merely rationalized revenge, and revenge is not a very noble emotion."126 Taylor received a similar response from the halls of academia: in J.D. Morton's view, retributivism amounted to "a thinly disguised averrment [sic] of the moral propriety of vengeance," which "is not a desire to be satisfied within our present JudeoChristian morality." ${ }^{127}$ Sometimes abolitionists merely discussed the two concepts as a natural pair rather than explicitly declaring them to be a single phenomenon. Arthur Maloney made this his practice. "There is no question of revenge or retribution, I am sure, that enters into the thinking of any of us in this house, and certainly not into the thinking of anyone who favours the retention of the penalty of death," he declared to his parliamentary colleagues, possibly naively, probably tongue-in-cheek. ${ }^{128}$ To many debaters, doubts about the moral status of retribution largely dissipated when the idea of vengeance entered into discussion. Revenge dwelt in morally unwholesome territory, and they could therefore confidently say the same of retribution.

Discussing the revenge possibly embedded in penal affairs implied that the phenomena requiring ethical evaluation consisted not only of the offender's conduct or of the degree to which the penalty itself aligned with normative criteria, but also of the attitudes and intentions of those who supported punishment. Such a dynamic made the

${ }^{126}$ J.K. Payne, letter to the editor, Globe and Mail, April 23, 1958, p. 6.

${ }^{127}$ Morton, "Murder Most Foul," 115; see also 114-117.

${ }^{128}$ House of Commons Debates (18 February 1960), 1198 (Arthur Maloney, MP - Progressive Conservative, Parkdale, ON). For other examples in which he spoke of the two in immediate conjunction and in clear disapproval, see Arthur Maloney, "Death Penalty: Facts Can't Justify Even Partial Retention," Toronto Daily Star, January 19, 1973, p. 6; LAC, MG32, Series B35 (Walter Gilbert Dinsdale fonds), Volume 79, File 5 - File Title: "Capital Punishment. General. Feb.-July 1976," transcript of 25 May 1976 meeting for parliamentarians in Railway Committee Room with panel of speakers sponsored by Canadian Society for the Abolition of the Death Penalty, p. 5-6 (speech by Arthur Maloney). 
discourse of revenge a potent critique of retributivism. Taylor tried to head off this tendency to perceive retributive thought itself as a superficial distraction from the more important story of related attitudinal phenomena. "[I]t is entirely fallacious to attempt to discredit retributive punishment by connecting it with the idea and motive of revenge," insisted Taylor. Indeed, "[r]etribution inflicted by a court of justice does not involve any feelings of revenge. Such a court simply accords to a man what he has earned," doing so "in strictest detachment," thereby "leav[ing] in retributive punishment no taint of the satisfaction of arbitrary emotion." 129 But abolitionists perceived the matter differently. Frank McGee spoke in Parliament about "what has always to my mind seemed the key aspect" of the controversy: "that capital punishment is essentially based on the motive and feeling of revenge." "Surely," he urged, "if motivations for laws exist, in this instance we should be motivated by a desire to protect the public ... rather than the indulgence of revenge." 130 A letter sent to the Globe and Mail criticized a judge who had declared retention to be in the right. "Such an attitude as expressed by Judge Macdonald ... is ... one of pure vengeance, which seems peculiarly repugnant to encounter among educated and civilized persons," declared his critic. ${ }^{131}$ "Have those MPs and citizens who favor retention of capital punishment carefully examined their motives?" asked another letter writer. "How can they find any justification except revenge[,] which is hardly a

\footnotetext{
${ }^{129}$ E.L.H. Taylor, letter to the editor, Globe and Mail, April 18, 1958, p. 6.

${ }^{130}$ House of Commons Debates (24 March 1959), 2199 (Frank McGee, MP - Progressive Conservative, York-Scarborough, $\mathrm{ON}$ ).

${ }^{131}$ C.O. Bagnell, letter to the editor, Globe and Mail, December 22, 1962, p. 6. For a brief report on what the judge said, see Canadian Press, "Given Ovation: Backs Hanging," Globe and Mail, December 18,1962 , p. 35.
} 
virtue upheld by the Christian religion many of them embrace[?]"132 When revenge became the topic of discussion, retentionists found that their own psychological processes now comprised the primary item for moral assessment. ${ }^{133}$

If mention of revenge implicitly signaled Canadians to gaze in the mirror and into their own hearts, it did not leave them without a context within which to interpret what they perceived in their own moral makeup. One aspect of that context was the familiar assumption of historical progress, an assumption directly reinforced by the critique of revenge itself. Few people raised their voices against revenge so passionately as those who preferred to envision human life, both descriptively and normatively, as throbbing with a progressive pulse. The death penalty "is murder legally permitted by those members of society who have never managed to outgrow primitive traits of bloody vengeance," blazed one citizen. ${ }^{134}$ "I urge the members of this House and all Canadians," exhorted an abolitionist MP, "not to regress to the barbaric practices of our ancestors. Surely, in a civilized and forward looking society, the philosophy of an eye for an eye or of brutal blood lust has no place." The retentionist cause would succeed "if we forgo reason and regress to emotionalism or a primitive desire for revenge."135 If not all debate

\footnotetext{
${ }^{132}$ (Mrs.) Marion Spencer, letter to the editor, Toronto Daily Star, November 24, 1967, p. 6.

${ }^{133}$ See especially House of Commons Debates (15 June 1976), 14498 (Ed Broadbent, MP - NDP, Oshawa-Whitby, ON). For other examples in which the discussion of vengeance made explicit mention of motivation, attitude, and so forth, see, for example, V. Sarty, letter to the editor, Toronto Daily Star, night edition, December 18, 1962, p. 6 (p. 99 in digital archive); Barrie G. Syme, letter to the editor, Toronto Daily Star, March 22, 1965, p. 6; Arthur Maloney, "Death Penalty: Facts Can't Justify Even Partial Retention," Toronto Daily Star, January 19, 1973, p. 6; House of Commons Debates (20 February 1973), 1483 (Ed Nelson, MP - NDP, Burnaby-Seymour, BC).

${ }^{134}$ M.E. Willmot, letter to the editor, Globe and Mail, March 1, 1960, p. 6.

${ }^{135}$ House of Commons Debates (22 May 1973), 3963 (Cyril Symes, MP - NDP, Sault Ste. Marie, ON). For similar examples, see John Tilton, letter to the editor, Toronto Daily Star, December 17, 1959, p. 6; House of Commons Debates (16 May 1973), 3846-3847 (David Lewis, MP - NDP, York South, ON); House of Commons Debates (6 May 1976), 13259 (John Gilbert, MP - NDP, Broadview, ON).
} 
participants felt inclined to agree with such statements, it was nevertheless difficult to avoid hearing them or to remain unaffected by the notion that revenge and progress could not dwell in harmony.

In her analysis of the mid-1950s joint committee that delved into the death-penalty controversy, Carolyn Strange has suggested that parliamentarians on this committee, including the many retentionists in the group, wished to avoid associating themselves with a mentality of revenge. ${ }^{136}$ More generally, it has been suggested that while Western culture had long fostered an ethic of putting a halt to one's own plans for revenge, perhaps anglophone culture had never provided so little ethical space for revenge or its proxies as in the twentieth century. ${ }^{137}$ The character of the Canadian debate on the death penalty gives little cause to doubt such portrayals. In the 1967 parliamentary debate, Lester Pearson unleashed his pitch for abolition in lively phrases before an equally lively House of Commons. The Hansard transcription of one section of his speech comically conveys the negative attitude in the parliamentary milieu toward vengeful values and retributive penal principles:

Mr. Pearson: I believe the only logical explanation left for retaining capital punishment in our society is a desire for retaliation Some hon. Members: No, no. Mr. Pearson: - and for revenge. Some hon. Members: No, no. Mr. Pearson: It is to make the punishment fit the crime. Some hon. Members: No, no.

Mr. Pearson: The criminal kills, so he must be killed.

Some hon. Members: No, no.

\footnotetext{
${ }^{136}$ See Strange, "Undercurrents," 374.

${ }^{137}$ See Susan Jacoby, Wild Justice: The Evolution of Revenge (New York: Harper \& Row, 1983), especially 1-20, 34-36, 52-53; see also Garland, Culture of Control, 9.
} 
Mr. Pearson: Well, Mr. Speaker, I cannot believe that this is an adequate reason in any society that aspires to become truly civilized. ${ }^{138}$

Attacks such as Pearson's drew blood and provoked defensive measures. Some retentionists challenged the depiction of retributive thought as vengeful. ${ }^{139}$ Others, however, sought to dissociate themselves from revenge by emphasizing their credentials as retentionists seeking to meet Canadians' practical needs. "I am quite sure a large majority of people wish capital punishment retained — not as revenge but rather to protect society," wrote William Dennison, an eminent Toronto municipal official. ${ }^{140}$ The death penalty "is not a matter of revenge, but of self defence," asserted a letter to the Toronto Daily Star. ${ }^{141}$ After abolitionist MP John Gilbert quoted Father Kelly extensively to the House of Commons, retentionist Joseph O'Keefe responded that "the quotation of the hon. member seemed to concentrate on retribution only.... Surely the important part of punishment is its deterrent effect. I am not interested in retribution, as I hope I am not a very revengeful person." 142 A few weeks after Pierre Laporte's death in the October Crisis, ${ }^{143}$ certain opposition MPs sought to make lethal sentences possible for cases similar to Laporte's, using a proposed amendment to the Public Order (Temporary Measures) Act as the vehicle for this initiative. As the brief debate on the soon-to-be-

\footnotetext{
${ }^{138}$ House of Commons Debates (16 November 1967), 4370-4371 (Lester Pearson - Liberal, Algoma East, ON).

${ }^{139}$ See, for example, House of Commons Debates (24 May 1973), 4057, 4059 (Réal Caouette, MP - Ralliement Créditiste, Témiscamingue, QC); House of Commons Debates (1 1 May 1976), 13407 (Peter Masniuk, MP - Progressive Conservative, Portage, MB).

${ }^{140}$ William Dennison, letter to the editor, Globe and Mail, February 11, 1960, p. 6.

${ }^{141}$ J.H., letter to the editor, Toronto Daily Star, December 16, 1964, p. 6.

${ }^{142}$ House of Commons Debates (24 March 1966), 3151 (Joseph O'Keefe, MP - Liberal, St. John's East, NF); see also House of Commons Debates (24 March 1966), 3148-3149 (John Gilbert, MP - NDP, Broadview, ON).

${ }^{143}$ See Robert Bothwell, Ian Drummond, and John English, Canada Since 1945: Power, Politics, and Provincialism, rev. ed. (Toronto: University of Toronto Press, 1989), 372.
} 
rejected amendment drew near its end, one MP championing the initiative protested that

there has been much talk about vengeance, about the fact that those who moved the amendment and who spoke in favour of it are motivated by vengeance. I assure the committee that this feeling is not motivating me one bit. I am motivated by the fact that our whole system of justice is based upon the effectiveness of a deterrent. ${ }^{144}$

Various retentionists may indeed have cared primarily about deterrence all along, ${ }^{145}$ but the wariness that many other Canadians displayed toward revenge in particular and retributivism in general helped to keep such retentionists on the pragmatic straight and narrow.

On June 15, 1976, Pierre Trudeau took his turn in the parliamentary death-penalty debate. ${ }^{146}$ Part-way through his speech he declared:

The deterrent effect of capital punishment is at the very core of the issue, and since one's moral view of the justification of capital punishment is entirely determined by one's judgment of its deterrent effect, the proper focus of this debate is factual data and logical induction, not moral philosophy. In that sense, the issue before us must be resolved by a practical rather than a moral judgment. ${ }^{147}$

If we were to glance at this comment hastily and ignore the rest of his speech, we might

${ }^{144}$ House of Commons Debates (10 November 1970), 1082 (Jack Horner, MP - Progressive Conservative, Crowfoot, AB). See pages 1071-1082 for the whole debate on this amendment. For other instances in which retentionists portrayed their stance as revenge-free, infused instead with an ethos of deterrence or of other strategies for placing a chill on crime, see, for example, House of Commons Debates (4 April 1966), 3831-3833 (W.H.A. Thomas, MP - Progressive Conservative, Middlesex West, ON); House of Commons Debates (9 November 1967), 4113 (George Hees, MP - Progressive Conservative, Northumberland, ON).

${ }^{145}$ For the same point, see Vidmar, "Attitudes toward the Death Penalty," 354; for a related point, see Chandler, Capital Punishment in Canada, 205 n. 53.

${ }^{146}$ In one contemporary observer's opinion, the decision of a small but key group of MPs to join the abolitionist cohort by the time of second-reading vote on the 1976 legislation illustrated the influence of this "dramatic pro-abolition speech" - see Geoffrey Stevens, "A Day of High Drama," Globe and Mail, June 23, 1976, p. 6.

${ }^{147}$ House of Commons Debates (15 June 1976), 14500 (Pierre Trudeau). 
conclude that Trudeau considered deterrence an important topic and morality an unimportant one in the capital punishment debate. Similarly, if we were to peruse lightly the parliamentary debate as a whole, we might possibly conclude that the frequent discussion of the workings of deterrence reflected debaters' choice to examine a nonmoral topic instead of moral controversies that failed to elicit their interest. Both conclusions would sail wide of the mark. Indeed, as the above quotation itself hints, moral assumptions and evaluations actually played as great a part in Trudeau's decision to emphasize the deterrence issue as this chapter has shown them to have played in the debate as a whole.

In fact, Trudeau's speech dealt with a remarkable number of the ethical considerations that had led debaters of the past two decades to talk about deterrence. His discussion suggested that execution and sound ethics might potentially find a zone of mutual harmony, should exigencies reach a particular threshold. "[T]he protection of innocent people against assaults on their lives and liberty is one of the highest duties of the state," Trudeau declared. "There are those," he acknowledged, "who sincerely believe that no man or group of men ever have the right to end a human life.... I am not one of those who share that belief." After all, "[m]oral philosophers and theologians have recognized for many centuries the right of a country to defend itself in a just war, even when such defence involves the killing of enemies." Accordingly, "[t]he question is whether state execution is an effective deterrent to murder, and therefore a justifiable act of collective self-defence." But in answering this question, Canadians faced the obligation to interpret "effective deterren[ce]" as a criterion not easily fulfilled. "[F]ree 
peoples," he explained, "have always insisted that the onus is on the person who would interfere with another's life or liberty to prove that such interference is necessary for the common good" - a statement well befitting Trudeau the Catholic supporter of liberalism. In sum, such considerations created a potential societal role for capital punishment as a murder retardant, but they also stipulated that the death penalty could remain on the job only if it could produce a résumé demonstrating a history of visible success in this role. ${ }^{148}$

And this conclusion held firm partly because retributivism remained morally objectionable. Trudeau's words made his stance on retributive principles per se somewhat unclear. In 1973 he had claimed that "justice ... is always a fleeting concept, and almost always subjective."149 While such a statement might imply skepticism toward the retributive point of view, he now granted "that society has the right to punish a criminal and the right to make the punishment fit the crime." However, any flirtation with retributivism ended when lethal punishment came into view. "[T]o kill a man for punishment alone is an act of revenge - nothing else," asserted Trudeau. "Some would prefer to call it retribution because that word has a nicer sound. But the meaning is the same." And he could not look favourably upon "the society which adopts vengeance as an acceptable motive for its collective behaviour." 150 Trudeau steered clear of flowery talk of "barbarism," "enlightenment,"151 and "the growing morality of man."152 But he

\footnotetext{
${ }^{148}$ Ibid., 14500-14501.

${ }^{149}$ House of Commons Debates (16 May 1973), 3842 (Pierre Trudeau).

${ }^{150}$ House of Commons Debates (15 June 1976), 14500-14501 (Pierre Trudeau).

${ }^{151}$ House of Commons Debates (23 July 1973), 5886 (John Gilbert, MP - NDP, Broadview, ON).

${ }^{152}$ (Rev.) J. Franklin Chidsey, letter to the editor, Globe and Mail, April 23, 1958, p. 6.
} 
asserted that taking the path of revenge would amount to "snuff[ing] out some of that boundless hope and confidence in ourselves and other people which has marked our maturing as a free people," an optimism that he endorsed. ${ }^{153}$ In comparison with such a vision, retribution looked ethically dark.

In 1976, many citizens felt that Trudeau's outlook on capital punishment failed badly to jibe with most citizens' perspectives. ${ }^{154}$ In one sense they were correct, given the popularity that the retentionist cause had acquired in recent years. But few succeeded better than Trudeau in summing up the ethical views embodied in the mainstream public discussion of capital punishment during the preceding twenty years. To him, as to so many others, these ethical ideas suggested that the assessment of deterrence should be sent to the top of the debate agenda. It is no surprise that, for much of these two decades, those who shared this perspective saw their wish come true.

${ }^{153}$ House of Commons Debates (15 June 1976), 14500-14501 (Pierre Trudeau).

${ }^{154}$ For examples of the criticism flying at Trudeau, see the letters to the editor from M. LeSage, Brian D. Wood, H. Reynolds, and N. Swain in the Toronto Daily Star, July 3, 1976, p. B3. 


\section{Chapter 3: Victims, Murderers, and the Rest of Us: Moral Evaluation Via Statements of Contrast and Assignment of Priority}

The Canadian news for October 1, 1959, contained a striking item from the judicial sector: the authorities' to-hang list now included one Steven Truscott, a teenage Ontarian. It had taken fewer than thirteen years for Lynne Harper to get to life's finish line - a June 1959 finish line consisting of a murderous strangulation, courtesy of Truscott, according to the verdict of the just-concluded murder trial. According to the official sentence, life's finish line now lay not far in the future for Truscott, and for him too it was to involve something looped around his neck - although in the end that lethal scenario would unfold only in the realms of imagination, thanks to a widely predicted commutation. $^{1}$

Early the next week, Toronto Daily Star readers got to hear what Pierre Berton, a frequent commentator in the paper, thought about the matter. Prose may have been Berton's bread and butter, but this time he tried his hand at verse. "Requiem for a Fourteen-Year-Old" called the reader to the scene of the jail containing Truscott, ... the small, scared boy On the small, stark bed A fourteen-year-old

Who is not quite dead.

Berton offered advice too:

${ }^{1}$ See Globe and Mail, "Order Death for Boy, 14, at Goderich," October 1, 1959, final edition, p. 1; Toronto Daily Star, "Women Sob As Boy Sentenced to Death," October 1, 1959, p. 1-2; Julian Sher, "Until You Are Dead": Steven Truscott's Long Ride into History, research assistance by Theresa Burke (Toronto, ON: Alfred A. Knopf Canada, 2001), 1-3, 7-8, 176, 282-284, 323, 329-330, 334, 338; Isabel LeBourdais, The Trial of Steven Truscott (Philadelphia, PA, and New York, NY: J.B. Lippincott Company, 1966), 224226. 
Sing a lament and sing it well,

But not for the boy in the cold, dark cell,

Save your prayers for the righteous ghouls

In that Higher Court who write the rules

For judge and jury and hangman, too:

The Court composed of me and you. ${ }^{2}$

Some other people thought along similar lines. "I feel ashamed that my adopted, allegedly Christian country should lower itself to provide a Roman holiday for those who cry for blood," said one letter writer in the Globe and Mail two days earlier. ${ }^{3}$ The desire to give the authorities a tongue-lashing over what Truscott encountered in the judicial system in 1959 would grow far more widespread after March 1966, when "probably innocent" began to sound to many Canadians like a good descriptor for Truscott, thanks to Isabel LeBourdais' book The Trial of Steven Truscott. ${ }^{4}$ But in October 1959, Berton's poem did not sit quite right with some Daily Star readers. "I would suggest," wrote one in a letter to the editor, "that if he again feels the approach of the muse he write about the feelings of the little girl upon meeting the murderous eye of her assailant."5 Berton's effort stacked up well on some counts, noted another, but there would have been greater merit in drawing attention to the sadness of Harper's end. "Our tears might well be saved for her parents." Another thought that Berton had "go[ne] off the deep end.... What is

${ }^{2}$ Pierre Berton, "Requiem for a Fourteen-Year-Old," Toronto Daily Star, October 5, 1959, p. 25. The front page of the paper (at least of the Metro Edition) called attention to Berton's verse on page 25. See also LeBourdais, Trial of Steven Truscott, 226-229, and Sher, "Until You Are Dead," 332-333. Both of these books point to the atypical use of verse on this occasion and quote Berton's poem in whole or in part.

${ }^{3}$ Otto G. Beck, letter to the editor, Globe and Mail, October 3, 1959, p. 6.

"LeBourdais, Trial of Steven Truscott (note that "probably innocent" is not a quotation from LeBourdais' book, or at least is not offered here as such). For a sense of Canadians' outlook in 1966 concerning this book and Truscott's story, see Sher, "Until You Are Dead," 385-391.

"'Old Fashioned," letter to the editor, Toronto Daily Star, October 8, 1959, p. 6.

${ }^{6}$ (Mrs. E.J.) L. Irene James, letter to the editor, Toronto Daily Star, October 8, 1959, p. 6. 
Mr. Berton trying to prove? That this boy is a martyr, a hero, or what?"7 Those examining the poem would find "not even a word for the hapless victim of the tragedy," observed "A Father," who considered this cause for "disgust." A few others raised similar points. ${ }^{9}$

Even before the Daily Star had published all of these letters, the paper's subscribers got to read Berton's rejoinder to his readers' objections. The total number of citizens who gave him a piece of their mind far exceeded the missives appearing on the letters-to-the-editor page, a fact made clear by the comments he devoted to the topic in the October 13 paper. To some, Berton's offence had consisted in failing to direct readers' thoughts toward Harper. The desire that she be given time in the foreground of the story was certainly understandable, Berton acknowledged, although he believed a "self-evident" consensus existed that Harper's demise constituted cause for grief, while the lack of consensus about Truscott's situation created a need for advocacy. But as certain readers saw it, the poem demonstrated that a murderer had found another friend, and they disapproved of how eager Berton seemed to be to play that role. ${ }^{10}$ Berton objected to their perception: "my lament was not for the boy or his parents but for a society which boasts of being civilized and still carries on its statute books a law that

\footnotetext{
${ }^{7}$ Edgar S. Mould, letter to the editor, Toronto Daily Star, October 9, 1959, p. 6.

"“A Father," letter to the editor, Toronto Daily Star, October 14, 1959, p. 6.

${ }^{9}$ See "A Mother," letter to the editor, Toronto Daily Star, October 8, 1959, p. 6; (Mrs.) W.
} Cookson, letter to the editor, Toronto Daily Star, October 14, 1959, p. 6; Zita M. Sampson, letter to the editor, Toronto Daily Star, October 14, 1959, p. 6. For three letters with only positive comments concerning Berton's piece, see Victor Campbell, letter to the editor, Toronto Daily Star, October 8, 1959, p. 6; Stan Obodiac, letter to the editor, Toronto Daily Star, October 8, 1959, p. 6; G.J.G-Williams, letter to the editor, Toronto Daily Star, October 14, 1959, p. 6.

${ }^{10}$ Pierre Berton, "In Which I Answer Some Mail," Toronto Daily Star, October 13, 1959, p. 21. For a much later statement that "[t]he cabinet is becoming known as the murderers' friend," see House of Commons Debates (22 November 1967), 4588 (Ralph Cowan, MP - Liberal, York-Humber, ON). 
belongs to the Dark Ages." An idea he had already included in the poem seemed to bear repeating: "It is not the court or the hangman whom we must weep for in this grisly matter, but the multitudes who guide their hands - ourselves."11

The disagreement between Berton and certain readers concerning the appropriate way of thinking about Truscott's plight illustrates one of the ongoing contrasts between retentionist and abolitionist rhetoric. Throughout the debate, retentionists and abolitionists tended to emphasize different issues when discussing which characters in the drama of murder and punishment should, morally speaking, be the leading recipients of Canadians' sympathetic attention. ${ }^{12}$ In the eyes of many retentionists, the murderer would need to settle for second place or worse within Canadian minds and hearts, well to the rear of the murder victim, whom some retentionists liked to describe as "innocent" or "law-abiding." Retentionists' discussion of the victim often served in part to convey the sense that those wishing to develop a morally upright viewpoint on the death penalty would ultimately have to join the retentionist camp. Some abolitionists sought to distance themselves from killers, thereby displaying a certain degree of agreement with their rivals in the debate. However, abolitionists turned their eyes not just toward murder victims, but also to the onlookers and adjudicators in the phenomena of crime and punishment - the citizenry itself. In adhering to an anti-death-penalty policy, Canadians

\footnotetext{
${ }^{11}$ Pierre Berton, "In Which I Answer Some Mail," Toronto Daily Star, October 13, 1959, p. 21. Most of the last quotation and part of the preceding one are also quoted in Sher, "Until You Are Dead," 333; see also LeBourdais, Trial of Steven Truscott, 229-230.

${ }^{12}$ For two of the other sources that use the image of a drama in discussing capital punishment or punishment more generally, see Chandler, Capital Punishment in Canada, xxii-xxiii; Peter Oliver, 'Terror to Evil-Doers': Prisons and Punishment in Nineteenth-Century Ontario (Toronto: University of Toronto Press, 1998), 30.
} 
would be doing themselves a morally refining favour, suggested abolitionists. And the moral rewards thereby available both to individual citizens and to the nation as a whole warranted Canadians' close attention whenever they delved into the controversies surrounding murder and the death penalty.

\section{Retentionists, Victims, and Murderers}

As seen in the preceding chapter, retentionists sometimes found it difficult to persuade their audiences that a murderer's moral and legal guilt itself ought to make authorities willing to call the executioner into action. ${ }^{13}$ However, retentionist arguments could acquire moral energy through other types of claims as well. Many retentionists, for instance, liked to suggest that abolition or abolitionist ways of thinking entailed a morally improper stance toward murderers relative to society's stance toward murder victims. Pro-capital-punishment statements conveyed this notion in various ways throughout the debate. "It is strange — and evil — to see the mawkish sympathy for murderers — but none for the widows and orphans of the victims," declared one letter to the editor in the Globe and Mail in January $1960 .{ }^{14}$ "Where any country begins to think more of the criminal than it does of the victim, then that country is indeed in a horrible state of affairs," declared an MP in 1973. ${ }^{15}$ One British Columbian speaking his mind in 1976 thought that certain pro-abolition Canadians deserved a colourful new label:

\footnotetext{
${ }^{13}$ For an example of a citizen who seemingly would not have accepted this type of retentionist idea, see Robert B. Gray, letter to the editor, Globe and Mail, February 19, 1960, p. 6.

${ }_{15}^{14}$ Clive A. Thomson, letter to the editor, Globe and Mail, January 28, 1960, p. 6.

${ }^{15}$ House of Commons Debates (29 January 1973), 750 (Ross Whicher, MP - Liberal, Bruce, ON).
} 
"murderians." "MURDERIANS," he vented, "always SHOUT: 'POOR CRIMINALS' only, but never POOR VICTIMS: the innocent children, law-abiding citizens, prison guards, policemen, hostages, parents, widows, orphans!"16

Sometimes retentionists used such claims as a supplement to their assertions that adherence to moral directives of a transcendent variety required assent to a retentionist policy. The January 1960 letter writer quoted in the preceding paragraph spoke about victims' family members vis-à-vis murderers, but his letter majored in discussion of scriptural issues. ${ }^{17}$ A letter appearing in the Globe several days later used a similar combination of themes. Scriptural claims took the lead, and reference to victims added a second dose of rhetorical momentum:

The modern man's sympathy and concern for the life of the murderer seems very irrelevant - almost hypocritical - when contrasted with his lack of concern and sympathy for the murdered victim and the latter's relatives, and his apparent inertness in decreasing the ever-mounting daily carnage on the nation's highways. ${ }^{18}$

But perhaps morally passionate discussion of victims occasionally acted more as a replacement for than as a supplement to ethical assertions that pointed toward the transcendent. The statements of Liberal MP Ralph Cowan provide an important example. During the mid-1960s, few if any MPs could have laid better claim than Cowan to the title of parliamentary retentionist-in-chief. At least that is the impression one might gain from the frequency of his appearance in news and commentary pertaining to the death-

\footnotetext{
${ }^{16}$ LAC, MG32, Series B35 (Walter Gilbert Dinsdale fonds), Volume 79, File 4 - File Title: "Capital Punishment. General Jan.-June 1976," Dr. N.G. Guntscheff to Ron Basford, June 23, 1976. This missive was titled "An Open Letter" and was cc'd to "All M.P.'s," and "The Press Gallery."

${ }^{17}$ Clive A. Thomson, letter to the editor, Globe and Mail, January 28, 1960, p. 6.

${ }^{18}$ George J. Amold, letter to the editor, Globe and Mail, February 6, 1960, p. 6.
} 
penalty controversy. With Cowan on board, the retentionist cause ran far less risk of losing any battles due to verbal timidity. For one thing, a knack for speaking at high volume, especially when seeking to impress a given point upon listeners, appears to have been one of Cowan's fortes, as it were. ${ }^{19}$ Moreover, learning that opinion leaders saw a given issue in a different light than he did does not seem to have typically moved Cowan — a "maverick," as the press liked to call $\mathrm{him}^{20}$ — to bite his tongue, or at least not so often as was true of other MPs. Had Cowan's efforts in the public arena been successful, certain other developments of the 1960s that became key features of Canadian life would have fizzled instead of flourishing. Emerging ideas about bilingualism had to take especially hard punches from Cowan; ${ }^{21}$ he targeted unloving words at the Pill as well. ${ }^{22}$ None of this is to say that arguing with Cowan necessarily turned out to be wholly disagreeable, as he was apparently blessed with a sense of humour. ${ }^{23}$ But abolitionists would always find him to be a feisty opponent.

\footnotetext{
${ }^{19}$ See Richard Snell, "Now They Want Ralph Cowan To Sit with Gilles Gregoire," Toronto Daily Star, April 8, 1967, p. 8.

${ }^{20}$ See editorial, "He Just Followed the Rules," Globe and Mail, March 31, 1966, p. 6; editorial, "Has Mr. Cowan Found a Home?", Toronto Daily Star, April 3, 1967, p. 6; see also Ottawa Bureau of the Globe and Mail, "MPs May Cut Holiday for Hanging Debate," Globe and Mail, March 31, 1966, p. 1; Richard Snell, "Now They Want Ralph Cowan To Sit with Gilles Gregoire," Toronto Daily Star, April 8, 1967, p. 8; Ian Harrison, "Whatever Happened To the Candidates Who Lost in the Trudeau Landslide," Toronto Daily Star, June 26, 1969, p. 7. Other colourful descriptions of Cowan included "the medieval Liberal" (Kurt Loeb, letter to the editor, Globe and Mail, December 17, 1964, p. 6) and "the Liberal party's Public Liability Number One" (editorial, "Has Mr. Cowan Found a Home?", Toronto Daily Star, April 3, 1967, p. 6).

${ }^{21}$ See editorial, "He Just Followed the Rules," Globe and Mail, March 31, 1966, p. 6; editorial, "Has Mr. Cowan Found a Home?", Toronto Daily Star, April 3, 1967, p. 6; Richard Snell, "Now They Want Ralph Cowan To Sit with Gilles Gregoire," Toronto Daily Star, April 8, 1967, p. 8.

${ }^{22}$ See Martin Knelman, "MPs clash over the pill and abortion bill; 25 sip soft drinks, listen to Bible, Tennyson," Globe and Mail, March 2, 1966, p. 5; see also editorial, "Has Mr. Cowan Found a Home?", Toronto Daily Star, April 3, 1967, p. 6.

${ }^{23}$ See Richard Snell, "Now They Want Ralph Cowan To Sit with Gilles Gregoire," Toronto Daily Star, April 8, 1967, p. 8.
} 
In April 1965, Cowan referred in the House of Commons to "those of us who still have some respect for the moral law and believe in the retention of capital punishment."24 In September of the same year, an event in Toronto provided opportunity for a blunt Cowan assertion: "My stand is based entirely on moral law. I rely solely on the Holy Book. If I am elected I will do everything I can to fight in favor of keeping the death penalty." 25 His readiness to speak about "the moral law" remained alive and well as of March 1, 1966, when the Bohemian Embassy, a Toronto coffeehouse, brought Cowan and two others together for a debate dealing with contraception, abortion, and the death penalty. ${ }^{26}$ Cowan's offerings on the latter issue included, among other things, the declaration that "[y]ou'll find it in Genesis: 'Whosoever sheddeth the blood of man by man his blood shall be shed." He also declared that "[m]y convictions are based on the moral law of the Bible. I could not care less what human beings say. I'm willing to accept the Old Testament." Although the Globe and Mail article discussing the event does not make it quite clear whether he made this latter statement with respect to capital punishment or concerning another topic under discussion, the utterance does reveal the genre of moral vision to which he adhered. ${ }^{27}$ If Cowan thought that his listeners might profit from hearing the scriptural passages to which he pointed, not all of said listeners

\footnotetext{
${ }^{24}$ House of Commons Debates (12 April 1965), 214 (Ralph Cowan, MP - Liberal, York-Humber, ON).

${ }^{25}$ Quoted in editorial, "May the Bad Guys Win!", Globe and Mail, September 30, 1965, p. 6.

${ }^{26}$ See Martin Knelman, "MPs clash over the pill and abortion bill; 25 sip soft drinks, listen to Bible, Tennyson," Globe and Mail, March 2, 1966, p. 5; see also Encyclopedia of Music in Canada, s.v. "Coffeehouses," [online source accessed through search of the Canadian Encyclopedia online] $\mathrm{http}: / / \mathrm{www}$.thecanadianencyclopedia.com/index.cfm?PgNm=TCE\&Params=U1 ARTU0000752 (accessed June 28, 2007).

${ }^{27}$ Martin Knelman, "MPs clash over the pill and abortion bill; 25 sip soft drinks, listen to Bible, Tennyson," Globe and Mail, March 2, 1966, p. 5. The biblical quotation appearing in the Cowan quotation above is part of Genesis 9:6.
} 
agreed. "Isn't it fatuous today to present to intelligent people an argument based on the Old Testament?" suggested one of his debate opponents. ${ }^{28}$ Among the audience taking in the event was Randal Marlin, a don at the University of Toronto's New College, who used a subsequent letter to the Globe and Mail to air his views on the debaters' discussion of capital punishment. "That an educated man, let alone a Member of Parliament, should have expressed the views which you attributed to Mr. Ralph Cowan," noted Marlin along the way, "would have seemed to me incredible," were it not for the fact that he had witnessed it personally. ${ }^{29}$

Cowan scarcely appears to have been the type to shrink back due to rebukes from opponents, whether they hailed from academia or elsewhere. But when it proved convenient, he could move to an alternate rhetorical knoll from which to fire his retentionist salvoes. And indeed, his speech in the parliamentary death-penalty debate roughly a month later contained no references to Scripture or discussion of "the moral law." Instead, it centred largely upon a concept beginning with a "v": "victims." Dying in certain types of tragedies, such as some automobile mishaps, could at times create avenues for public funds to flow to one's family members, noted Cowan. Instances of murder seemed to be a different kettle of fish. "[W]e turn all the strength of the crown in

\footnotetext{
${ }^{28}$ Quoted in Martin Knelman, "MPs clash over the pill and abortion bill; 25 sip soft drinks, listen to Bible, Tennyson," Globe and Mail, March 2, 1966, p. 5; see Randal Marlin, New College, University of Toronto, letter to the editor, Globe and Mail, March 12, 1966, p. 6.

${ }^{29}$ Randal Marlin, New College, University of Toronto, letter to the editor, Globe and Mail, March 12,1966, p. 6. In the portion of the letter dealing with Cowan, Marlin seems to have focused primarily on the alleged lack of coherence in Cowan's claims and commitments, rather than unambiguously attacking the very idea of incorporating the Old Testament into one's argument on the issue. For evidence suggesting that Marlin was serving as a don at New College and may have also been lecturing at the University of Toronto at the time, see Randal Marlin's Curriculum Vitae on the Web site of the Centre on Values \& Ethics at Carleton University, http://www.carleton.ca/cove/cv/Marlin.htm (accessed June 16, 2007).
} 
behind the criminal to see that he gets three meals a day, has a warm bed, is looked after properly and is given a psychiatric examination," charged Cowan. "What about the victim? The attitude is: The victim is dead; skip it." If the Canadian population shrank by a total of one on the occasion of a murder, in many cases the membership of a family simultaneously shrank by the same number. For such a family, the future would feature grief, and sometimes a decreased bank account as well. "What," Cowan asked, "has the state cared up to this moment? It has done nothing: The victim is dead, so let the dead bury their dead." Things could be different if "a Criminal Injuries Compensation Board" were to begin operation in Canada, as could happen if legislators and government leaders put their minds to it. If he and other retentionist MPs had their way, claimed Cowan, the idea would win real time on the parliamentary agenda. Cowan referred to MPs pushing the abolitionist initiative as "those who want to aid and abet the criminal population." By contrast, "the retentionists in this house are thinking of the victims of murderers more than they are thinking of the criminal element who perform the murders." ${ }^{30}$

Scripture once again found a place in Cowan's retentionist discourse when he spoke to the House of Commons during the November 1967 death-penalty debate. But he also spent time highlighting "victims." ${ }^{31}$ On the whole, the theme of the victim would remain a more prominent part of his on-the-record message in the House of Commons at this time, largely because his idea of a Criminal Injuries Compensation Board became the

\footnotetext{
${ }^{30}$ House of Commons Debates (5 April 1966), 3899-3901 (Ralph Cowan, MP - Liberal, YorkHumber, $\mathrm{ON}$ ).

${ }^{31}$ See House of Commons Debates (16 November 1967), 4350-4351 (Ralph Cowan, MP - Liberal, York-Humber, $\mathrm{ON}$ ).
} 
subject of debate in its own right in Parliament for a short time on November $22 .{ }^{32}$ The House had heard Cowan's advocacy on this topic on more than one occasion since the capital-punishment debate in the spring of $1966 .{ }^{33}$ If Cowan liked to champion the idea, he could not truthfully portray all abolitionists as his enemies in this particular battle. Public funds for victims' families sounded quite desirable to various abolitionists, as had become evident through a good number of abolitionist statements in the mid-1960s. ${ }^{34}$ Nevertheless, discussing his compensation-board proposal still gave Cowan opportunities to contrast "victims" with "murderers," or to highlight the alleged differences between the retentionist and abolitionist perspectives concerning these two groups. As he put it now in November 1967, "When I listen to all the people running around this house of parliament weeping over the fate of murderers I am filled with disgust, because I weep over the fate of the victims, not the murderers. ${ }^{.35}$ With victim-themed rhetoric in his arsenal, Cowan did not need to emphasize divine directives to convey the sense that morally contemptible thinking was rare in the retentionist world, but could be found in plenty where abolitionist allegiance proved strong.

\footnotetext{
${ }^{32}$ See House of Commons Debates (22 November 1967), 4585-4593.

${ }^{33}$ See House of Commons Debates (8 June 1966), 6160-6162 (Ralph Cowan, MP - Liberal, YorkHumber, ON); (19 May 1967), 434-438 (Ralph Cowan, MP); see also (22 November 1967), 4585 (Ralph Cowan, MP).

${ }^{34}$ See, for example, House of Commons Debates (24 March 1966), 3107 (Gordon Fairweather, MP - Progressive Conservative, Royal, NB); (24 March 1966), 3150 (John Gilbert, MP - NDP, Broadview, ON); (5 April 1966), 3908 (Reid Scott, MP - NDP, Danforth, ON); (8 June 1966), 6164-6166 (Andrew Brewin, MP - NDP, Greenwood, ON); (8 June 1966), 6167-6168 (Warren Allmand, MP - Liberal, NotreDame-de-Grâce, QC).

${ }^{35}$ House of Commons Debates (22 November 1967), 4585 (Ralph Cowan, MP - Liberal, YorkHumber, ON); see also p. 4586, 4588. For less strongly worded statements by Cowan that nevertheless convey his feeling that a wrong-headed outlook conceming victims and killers existed in the abolitionist camp or within the government, see House of Commons Debates (8 June 1966), 6161-6162 (Ralph Cowan, MP - Liberal, York-Humber, ON); (19 May 1967), 434-435, 438 (Ralph Cowan, MP); (16 November 1967), 4350-4351 (Ralph Cowan, MP).
} 
During November 1967, Cowan repeatedly referred to victims as "innocent victims." ${ }^{36}$ The same phrase had appeared in certain retentionist statements in earlier stages of the public debate, and would continue to emerge in later retentionist rhetoric. Whatever reasons the various pro-death-penalty advocates may have had for adding the adjective "innocent" to their description of victims, the resulting verbal image helped to accentuate the hues of guilt in the contrasting image of the killer. According to one citizen,

too much sympathy and consideration are being given these fiends that commit such crimes and too little to their innocent victims and their families.

Who can imagine what mental and physical torture was suffered immediately before their deaths? Why should their murderers escape a comparable fate and also be in a position to rejoin society is the near future? ${ }^{37}$

"I am astounded," said another, "by the continuous bleating of the soft-headed bleeding hearts who perpetually whine and cry about the agony of a convicted murderer on the scaffold. They fail to mention the agony of an innocent victim at the hands of a callous murderer."38

As illustrated by the first letter quoted in the preceding paragraph, the phrase "innocent victims" could fit nicely into retentionist ruminations that conveyed a seemingly retribution-friendly message: "Why should their murderers escape a comparable fate ...?"39 However, as we shall see in a moment, retentionist arguments in

${ }^{36}$ See House of Commons Debates (16 November 1967), 4350-4351 (Ralph Cowan, MP - Liberal, York-Humber, ON); (22 November 1967), 4585-4888 (Ralph Cowan, MP).

${ }^{37}$ G.L. Davis, letter to the editor, Globe and Mail, February 3, 1965, p. 6.

${ }^{38}$ S. Campbell, letter to the editor, Toronto Star, December, 1, 1972, p. 7. For just two of the various other examples of references to "innocent victims" in singular or plural, see M.M. Stevenson, letter to the editor, Toronto Star, October 29, 1973, p. C5; Gertraud Tichy, letter to the editor, Toronto Star, June 29,1976, p. B5.

${ }^{39}$ G.L. Davis, letter to the editor, Globe and Mail, February 3, 1965, p. 6. 
which the death penalty wore a primarily instrumental hat could also put such terms as "victim," "innocent," and "law-abiding" to good use. Some retentionists probably expected that the latter type of argument offered the best chance for a discussion of victims to hit home with abolitionists. In abolitionists' view, pro-capital-punishment advocates had no right to make a retentionist perspective an entry qualification to the welove-victims club. "Hanging the murderer does not bring back his victim or comfort the victim's family," pointed out one citizen. ${ }^{40}$ But perhaps the slate of citizens winding up on the murder-victim list in the years ahead could be a little larger or a little smaller, depending upon the policies that authorities pursued in the meantime. If so, making the best decisions on the pertinent policy questions would amount to a pro-victim deed that could not be rivaled, abolitionists believed. As Warren Allmand put it in 1976, "I have stated repeatedly that my first concern is for victims, or to ensure lack of victims. My first goal as Solicitor General is to do everything possible to prevent crime and to reduce the number of victims." ${ }^{\prime 41}$ And the Canadian government could demonstrate full commitment to this type of pro-victim vision while also carrying out abolitionist initiatives, for, as Allmand put it in 1973, the death penalty "does nothing to help society, does nothing to help the victim, does nothing to help the family.",42

This type of perspective on victims had little in common with the way in which certain retentionists incorporated the concept of the victim into their assessment of the

\footnotetext{
${ }^{40}$ William Stroud, letter to the editor, Toronto Daily Star, February 3, 1966, p. 6.

${ }^{41}$ House of Commons Debates (29 June 1976), 14970 (Warren Allmand, MP - Liberal, NotreDame-de-Grâce, QC). See also House of Commons Debates (8 June 1966), 6167 (Warren Allmand, MP Liberal, Notre-Dame-de-Grâce, QC);

${ }^{42}$ House of Commons Debates (23 July 1973), 5902 (Warren Allmand, MP - Liberal, NotreDame-de-Grâce, QC).
} 
death penalty. "All the justification needed for the execution of a murderer is that victim buried in the ground who shouldn't be there," argued one citizen in $1960 .{ }^{43}$ "I cannot throw my support to a murderer simply because he is alive and the victim is dead," proclaimed MP Duncan Beattie in 1973. "I cannot," he continued later in his speech, "accept the premise that execution of a murderer does not bring the victim back to life or ease the burden on the victim's family, so there is no point in executions.... The point is that murder should carry a price as high as the value of the life taken." Beattie also exhorted his fellow MPs to "establish once and for all that we do not place the life of the murderer on a higher plane than the life of the victim." ${ }^{44}$ But other retentionists' perspective much more closely resembled the abolitionist framework. "I am concerned about convicted criminals," declared one pro-death-penalty MP, "but I am far more concerned about the innocent victims and, above all, the possible future victims." ${ }^{45}$ Noting Allmand's frequently expressed skepticism toward the idea of "help[ing] the victim by executing the offender," ${ }^{, 46}$ MP Allan Lawrence pointed out that "[w]hen a man or woman has been killed no one can possibly help them. What we should be worried about is the protection in the future of other innocents." ${ }^{.47}$ Like abolitionists, some retentionists preferred that the discussion of victims serve largely as an exercise in envisioning the future, and as an effort to seek the types of policies under which reading

\footnotetext{
${ }^{43} \mathrm{G}$. Rogers, letter to the editor, Globe and Mail; February 27, 1960, p. 6.

${ }^{44}$ House of Commons Debates (24 July 1973), 5925-5926 (Duncan Beattie, MP - Progressive Conservative, Hamilton Mountain, ON). East, NF).

${ }^{45}$ House of Commons Debates (24 March 1966), 3151 (Joseph O'Keefe, MP - Liberal, St. John's

${ }^{46}$ These are Lawrence's words - House of Commons Debates (18 October 1973), 6979 (Allan Lawrence, MP - Progressive Conservative, Northumberland-Durham, ON).

${ }^{47}$ Ibid.
} 
through the list of new victims might eventually take less time, due to the relative scarcity of entries thereon. ${ }^{48}$

To retentionists, of course, such a perspective on victims did not actually mesh too well with abolitionism. References to "innocent victims" or "law-abiding citizens" sometimes emerged when retentionists spelled out why their own view deserved assent. "Whose life," wondered MP Gordon Churchill in 1966,

is the more valuable. The murderer who murders again or the innocent victim?... Is the state justified in saving the life of a criminal without being able to give complete assurance that another innocent person may not be sacrificed to that criminal's rage, lust or homicidal tendency?

Were such "complete assurance" to emanate from the mouth of a Canadian leader at the present time, Canadians would not be wise to believe what they were being told.

Accordingly, "the state owes a higher duty to its law-abiding citizens, to its women and children, than it does to the criminal," and if legislators allowed that duty to sink in, they would find themselves joining the retentionist camp. ${ }^{49}$ Churchill would not be the last to envision post-abolition Canada as a country in which the odd citizen might possibly arrive at the morgue both earlier than normal and earlier than in a retentionist Canada. Nor would he be the last to discuss murderers and these "innocent" or "law-abiding" persons simultaneously, and to perceive this exercise in juxtaposition as a way to re-

\footnotetext{
${ }^{48}$ What I am discussing here are concrete instances of the familiar distinction between "backwardlooking" and "forward-looking" penal mind-sets - for a brief discussion, see Pojman, "For the Death Penalty," 7-9, 21-24, 26, especially 7, 22, and 26.

${ }^{49}$ House of Commons Debates (5 April 1966), 3865-3867 (Gordon Churchill, MP - Progressive Conservative, Winnipeg South Centre, MB). The quotations are from pp. 3865 and 3867.
} 
energize his retentionist song. ${ }^{50}$

A few retentionists appear to have believed that an argument of this type might provide the arguer with better chances of acquiring non-retributive credentials, or at least non-vengeful credentials. "I use the word treatment rather than punishment," noted MP Hugh John Flemming, "because I am sure in my own mind that no one today connects the death penalty with punishment for a crime. The removal of danger from innocent people is what the law was designed to accomplish." With capital punishment pacing the beat, fidgeting with its deterrent baton, that danger might leap out of the shadows at least slightly less often. "Do I vote to protect innocent and law abiding citizens from death by violence," queried Flemming, "or do I vote to be more lenient with the criminal who has deliberately planned violent death and has been convicted of the same after due deliberation?"51 Retentionist A.D. Alkenbrack may not have wanted to make the justice system a no-retribution zone, ${ }^{52}$ but he also hoped not to encounter too much retributivism staring out at him from the mirror. "I am not a vindictive man," he asserted, and to my knowledge no one has ever suggested that I am bloodthirsty. However, my concern is more for the innocent victim of crime than for the criminal; therefore, I cannot support a bill that does not provide that measure of

\footnotetext{
${ }^{50}$ See House of Commons Debates (11 May 1976), 13404-13405 (Gilbert Parent, MP - Liberal, St. Catharines, ON); (14 May 1976), 13543 (Frank Hamilton, MP - Progressive Conservative, Swift CurrentMaple Creek, SK); see also House of Commons Debates (10 June 1976), 14348 (Hugh Anderson, MP Liberal, Comox-Alberni, BC); (12 July 1976), 15234 (see also 15232) (Simma Holt, MP - Liberal, Vancouver-Kingsway, BC). Note, however, that straightforward retributive ideas appear in at least some of these speeches as well (see also House of Commons Debates [10 May 1976], 13376 [Simma Holt, MP]).

${ }^{51}$ See House of Commons Debates (5 April 1966), 3902-3906 (Hugh John Flemming, MP Progressive Conservative, Victoria-Carleton, NB). The quotations are from p. 3906.

${ }^{52}$ See House of Commons Debates (4 April 1966), 3825-3827 (A.D. Alkenbrack, MP Progressive Conservative, Prince Edward-Lennox, ON); see also (19 October 1973), 7067 (A.D. Alkenbrack, MP - Frontenac-Lennox and Addington, ON); (19 May 1976), 13684-13686 (A.D. Alkenbrack, MP).
} 
protection to which the victim is entitled. ${ }^{53}$

In 1975, Pierre Trudeau's mail readers got to examine a letter from a citizen who could not be accused of indifference:

I may say that I think I am as kind-hearted as any government member and I do NOT delight in seeing punishment administered for the sake of retribution, but let's not forget the victims. Let's be KIND to them. Think of the INNOCENT victims who are often tortured, dismembered, etc, before being killed. Often this includes INNOCENT CHILDREN and many members of one or more families. ARE THEY WORTH LESS THAN THE CRIMINAL??? Should criminals be parolled [sic] so they can be repeaters of the same or similar crimes?? THINK!! PLEASE THINK!! $!^{54}$

For many retentionists, the discussion of victims may have seemed compelling primarily because of the victims themselves. ${ }^{55}$ But as the examples in this chapter suggest, in at least some cases an additional interest also beckoned them to the topic. Although retentionists welcomed the victim into the rhetorical room, they often brought in a second guest at the same time, sometimes announcing him straightforwardly, sometimes via the whispers of implication. The second figure, of course, was the killer, in his morally darkened clothing — clothing that looked thoroughly dark, or perhaps merely a little darker than the victim's own, but sufficiently dark, in any case, to convey retentionists' pro-capital-punishment message, whether that message was facilitated by retributive energy or instead by instrumentalist vigour.

\footnotetext{
${ }^{53}$ House of Commons Debates (19 October 1973), 7069 (A.D. Alkenbrack, MP - Progressive Conservative, Frontenac-Lennox and Addington, ON).

${ }^{54}$ LAC, MG32, Series B27 (Marcel Lambert fonds), Volume 81, File 12 - File Title: "Capital Punishment 1975," (Mrs.) W. Knopp to Pierre Elliott Trudeau, January 22, 1975.

${ }^{55}$ For the idea that "a sense of compassion regarding the victims of violent murder" acted as one of the stimulants of some retentionists' retributive claims in the 1987 death-penalty debate in Canada, see Arron, "Punishment and Civilization," 74-75.
} 


\section{Abolitionists, Murderers, and the Rest of Us}

If some retentionists liked to imply that the adjectives "abolitionist" and "pro-murderer" deserved to appear in the same thesaurus entry, abolitionists thought the idea needed to be run through the guillotine. "The suggestion made by the police that abolitionists are dogooders and sob-sisters imbued with pity for hardened killers is completely unfounded and baseless," protested Arthur Maloney. "The abolitionists have no sympathy whatever for the murderer." ${ }^{\text {"S6 }}$ Some other abolitionists saw it the same way. "I take strong exception," declared MP Jack Cullen, "to those who say that we abolitionists ... have more concern for the accused than we have for the victim.... I have no sympathy - my heart is filled with revulsion at the thought that one individual would take the life of another." 57

Certain types of sympathetic feelings with respect to at least some aspects of killers' lives probably existed a little more plentifully in abolitionist circles than the above quotations might seem to suggest. A number of abolitionists had good things to say about the idea of compassion as well. ${ }^{58}$ But when abolitionists cast verbal dirty looks at murderers, they were indicating, among other things, that significant merit existed in a general outlook that was widespread in the country: namely, that those possessing an ethically wholesome mentality would be a little wary of quantitative or qualitative excess

\footnotetext{
${ }^{56}$ Arthur Maloney, "Does Retention Protect Police?" The Canadian Register (Kingston, ON), February 5, 1966, p. 5 (a clipping of this article is found in LAC, MG32, Series C31 [Heath Nelson Macquarrie fonds], Volume 42, File 32 - File Title: "Capital Punishment 1966"). Lambton, ON).

${ }^{57}$ House of Commons Debates (30 January 1973), 804 (Jack Cullen, MP - Liberal, Sarnia-

${ }^{58}$ See, for example, House of Commons Debates (16 May 1973), 3847 (David Lewis, MP - NDP, York South, ON); (6 May 1976), 13261 (Robert Daudlin, MP - Liberal, Kent-Essex, ON).
} 
when seeking to think, act, and speak kindly about or toward murderers.

It is useful to note three of the implicit messages that could be conveyed by statements in which abolitionists distanced themselves from killers and aligned themselves with the widespread outlook just noted. First, such abolitionists were trying to avoid "minimizing the horror of murder," to use the words of their fellow advocate Warren Allmand. ${ }^{59}$ Second, at least some abolitionists probably meant not just to indicate how vexing they found the lethal event itself, but also to emit signals of rebuke with respect to the killer's actions. Certain comments in Solicitor General Larry Pennell's 1967 speech revealed that he wanted retributive habits of thought to acquire little or no market share among penal and justice authorities, but this did not mean he would claim that all denunciatory dynamics had to be phased out of criminal justice. Denunciatory as the death penalty might be, "[w]e can denounce the terrible conduct of murderers far more impressively by declaring our profound belief in the sanctity of human life and substituting a sentence of life imprisonment." ${ }^{90}$

When envisioning "the terrible conduct of murderers," some abolitionists may have assumed that if the killer's murderous move drew upon energies of various types, one of these energies consisted of the smolder, blaze, or icy current of his will. Perhaps abolitionist MP Derek Blackburn was thinking of killings involving this sort of dynamic when he noted his own ability to leave the rose-coloured glasses on the shelf. "I am not a

\footnotetext{
${ }^{59}$ House of Commons Debates (3 May 1976), 13088 (Warren Allmand, MP - Liberal, NotreDame-de-Grâce, QC). Allmand himself was not here discussing his attitude toward killers.

${ }^{60}$ See House of Commons Debates (9 November 1967), 4080 (Larry Pennell, MP - Liberal, BrantHaldimand, $\mathrm{ON}$ ).
} 
bleeding-heart," he declared, "when it comes to sympathizing with a convicted murder [sic] who in cold blood and full knowledge of his act has taken the life of an innocent person." Blackburn did not, admittedly, present his hearers only with this verbal image of seemingly clear blameworthiness. He observed later in his speech, for instance, that "[m]ost murderers are not responsible for their crimes in a vacuum; all of us in Canadian society must share the responsibility because we allow conditions of poverty, exploitation and discrimination to exist in the context in which murder takes place."61 A speech by MP Jacques Olivier touched upon the same two dynamics in murder, but Olivier's words pointed to the second dynamic more clearly than to the first. He urged his hearers to realize what a bad idea it was to execute

anyone even though this person has willingly killed another person.

What is to be considered, I suggest, is the kind of society in which we live and what leads murderers to commit such acts. As a matter of fact, our society should be blamed rather than these people who, thanks to a whole set of circumstances, may have been very badly educated.

But although Olivier's killers sounded a little less independently villainous than Blackburn's man of "cold blood," Olivier still said later in his speech that "I hope people will understand that I do not pity the offenders." ${ }^{\text {"62 }}$ Perhaps he thought that a door labeled "the other choice" had stood unlocked and at least faintly visible even to a "badly educated" murderer, and that without the killer's unnecessary failure to turn the admittedly sticky doorknob, the experience of murdering someone would never have

\footnotetext{
${ }^{61}$ House of Commons Debates (22 May 1973), 3982, 3984 (Derek Blackburn, MP - NDP, Brant, ON). QC).

${ }^{62}$ House of Commons Debates (31 January 1973), 834 (Jacques Olivier, MP - Liberal, Longueuil,
} 
entered his world.

But perhaps Olivier also sensed that, were people's regret about a murder victim's calamitous experience as potent as it should be, they would tend to feel at least a dose of dislike for the killer, whatever the realities of blame per se. Perhaps a statement in Pennell's 1967 speech contains hints of this third type of idea — a victim-oriented idea — that could appear in abolitionist offerings of anti-murderer sentiment. No "misguided sense of sympathy for the enemies of society" polluted his abolitionist efforts, Pennell declared. "The view I take has nothing to do with sympathy for murderers. I recognize the sincerity and the conviction of hon. members who oppose this bill and I hope, in turn, that they will acquit me of any lack of feeling for the victims of these revolting crimes."13 In sum, whether conveying such ideas in obvious or ambiguous form, some abolitionists made it known that a murderer's search for unlimited approval, affirmation, and condolence would have to take him to some other destination than their own front door. If abolitionists considered it both rhetorically and morally dubious to speak and act in a manner that would make them look like murderers' lobbyists, there was another group of people possessing certain needs and interests that various abolitionists did like to point out. The group in question was a sizeable one - Canadians writ large. "I am not, you will note, speaking of sparing criminals," declared abolitionist Gérard Pelletier; "I am only speaking of sparing ourselves an action which we are all ashamed of and which, moreover, contradicts all our convictions and all our feelings about the sanctity of human

\footnotetext{
${ }^{63}$ House of Commons Debates (9 November 1967), 4077 (Larry Pennell, MP - Liberal, BrantHaldimand, $\mathrm{ON}$ ).
} 
life."64 "I do not oppose capital punishment because I harbour any sympathy or concern over the fate of murderers," asserted MP Peter Reilly. However, he noted, "I do care very much about the society in which I live and the effect on that society of state murder."65 While laying out one of his anti-death-penalty arguments, Pierre Trudeau declared that "[i]t should be understood that my primary concern here is not compassion for the murderer. My concern is for the society which adopts vengeance as an acceptable motive for its collective behaviour." 66 As these quotations suggest, in many cases the "concern" that abolitionists felt and discussed regarding Canada and its residents related at least in part to the degree of moral vitality present among citizens.

When discussing this moral vitality or lack thereof, abolitionists often spoke in language that seemed to point toward the citizenry in aggregate. But sometimes abolitionists' discussion encouraged their audience to contemplate the issue in question while envisioning the citizenry as made up of many individuals. The latter was especially true of such abolitionist statements as those made by a letter writer named Aaron Carbell in the February 25, 1960, edition of the Globe and Mail. "No person, agency, government or institution has the right to take a person's life," Carbell's letter began. "This is murder, pure and simple." ${ }^{67}$ Had he looked among a typical sample of abolitionists for co-signers for his letter, he would have received a number of refusals.

\footnotetext{
${ }^{64}$ House of Commons Debates (24 March 1966), 3103 (Gérard Pelletier, MP - Liberal, Hochelaga, QC).

${ }^{65}$ House of Commons Debates (29 January 1973), 727 (Peter Reilly, MP - Progressive Conservative, Ottawa West, ON).

${ }^{66}$ House of Commons Debates (15 June 1976), 14501 (Pierre Trudeau, MP - Liberal, Mount Royal, QC).

${ }^{67}$ Aaron Carbell, letter to the editor, Globe and Mail, February 25, 1960, p. 6.
} 
But he would have found at least some who liked the assertion. ${ }^{68}$ Some would also have liked another pair of sentences in the letter: "Every time a person is hanged, everybody in our society has had a part in cold-blooded, premeditated murder. We are all guilty." ${ }^{169}$ At least a few other abolitionist letters also dealt with or hinted at this theme regarding the guilt to be found in each Canadian's personal mailbox, courtesy of the active death penalty. "Those who pay for the rope have blood on their hands and it leaves a subtle but indelible mark," declared one writer. ${ }^{70}$ In December 1962 another asked, apparently in reference to the major capital-punishment story of the day, Lucas and Turpin's day of reckoning: "Who makes the laws? Was this unspeakable act of barbarism enacted in my name? How am I to relieve myself of the guilt which has been thrust upon me?"11 From one angle, abolitionists' comments concerning moral issues pertaining to the death penalty often involved pointing out moral deficiencies in Canada. From another angle, these comments drew attention to real or presumed moral desires among citizens. For instance, abolitionists' references to Canadians' alleged guilt represented an attempt not so much to accuse fellow citizens as to show them how much displeasure they actually received from said guilt and how much they would prefer to acquire no more.

\footnotetext{
${ }^{68}$ For another abolitionist letter containing a similar and equally strong statement, see (Rev.) J. Franklin Chidsey, letter to the editor, Globe and Mail, April 23, 1958, p. 6. Based on some of the data from at least one poll and one study, it appears that at least in the early 1970s there may have been a substantial number of abolitionists who thought along similar lines as Carbell on this point, although the evidence pertaining to this particular issue is somewhat ambiguous due to the form the data in question takes in these two sources - see Canadian Institute of Public Opinion, "63\% Want Death Penalty Restored for Murderers," news release (The Gallup Report), February 2, 1972; see Vidmar, "Attitudes toward the Death Penalty," 347.

${ }^{69}$ Aaron Carbell, letter to the editor, Globe and Mail, February 25, 1960, p. 6.

${ }^{70}$ John Stricek, letter to the editor, Toronto Daily Star, January 28, 1960, p. 6.

${ }^{71}$ John Hearn, letter to the editor, Toronto Daily Star, December 13, 1962, p. 6 (p. 99 in digital archive).
} 
"When we hang one person we are not merely killing a person, we are adding to our already overpowering guilt complex," urged Aaron Carbell. ${ }^{72}$ The latter days of November 1967 brought an opportunity for another abolitionist to make a happier point about the effect of abolition upon the same type of dynamic to which Carbell referred. Given Bill C-168 and the second-reading voting outcome of which it could now boast, ${ }^{73}$ many observers would have had little difficulty in forecasting one of the criminal-justice realities of the Canadian near future: namely, that although the 1968-1972 period might well give news outlets and local grapevines some opportunity to tell of new Canadian murders and the corresponding trials, on very few occasions would there be any word to give of a death sentence. ${ }^{74}$ This development looked unappealing to some Canadians. In the view of at least a few retentionists, the thought that the word "murdered" might appear in one's own obituary now belonged slightly less to the category of paranoid ideas and slightly more to the category of possible eventualities than had previously been the case. On November 28, a letter in the Toronto Daily Star by one John S. Lynn offered some criticism of this latter idea — and made what he considered to be another compelling point:

We have no real assurance that people sleep easier under a sentence that inflicts death than they do under a penalty that imposes life.

But at least their sleep won't be disturbed by the spring of the death-trap. Abolition of the death penalty ends the nightmare of brutal hangings and removes

\footnotetext{
${ }^{72}$ Aaron Carbell, letter to the editor, Globe and Mail, February 25, 1960, p. 6.

${ }^{73}$ See Journals of the House of Commons of Canada, $2^{\text {nd }}$ Session, $27^{\text {th }}$ Parliament, Volume 114, No. 86 (23 November 1967).

${ }^{74}$ Of the death sentences materializing in the Canadian court system, it appears that just six date from these years - see Canada, Ministry of the Solicitor General, Questions and Answers, Question No. 38.
} 
the guilt complex from one's conscience. ${ }^{75}$

Many Canadians were probably less prone to pangs of guilt concerning executions than Lynn's words might suggest. But the fact that he portrayed their consciences as sufficiently active for a guilt complex to have coalesced illustrates again that some abolitionists liked to make statements that might spark their listeners' desire for strong ethical vitality. And perhaps his statement also suggests how important certain abolitionists perceived individuals' own moral cognizance and commitment to be. Another type of claim also allowed abolitionists to make use of their hearers' presumed desire to be non-murderous. Capital punishment "forces me to descend to the same level as the murderer I am hanging," declared one MP. "It is sanctioned murder and I resent having to participate in it or have any part in it because it drags me down to the level of the person who is sentenced to death. ${ }^{.76}$ Capital punishment of a killer "brutalizes society and lowers it toward his own depraved and savage level," affirmed another. ${ }^{77}$ "There is one reason, and one reason alone why people insist on capital punishment, and that is revenge," argued MP Peter Reilly. Revenge and murder would blaze in his head and hands were he to find his own offspring murdered, but

[t]hat wish is not rational, and its fulfilment would do me a terrible disservice. It demeans me and brings me to the level of that pitiable creature who wronged my child. It renders me no less contemptible than the murderer. I submit that to the extent that one of us is demeaned and sickened in this fashion, society is contaminated by the disease. I do not want that kind of society, and I do not want

\footnotetext{
${ }^{75}$ John S. Lynn, letter to the editor, Toronto Daily Star, November 28, 1967, p. 6.

${ }^{76}$ House of Commons Debates (28 March 1966), 3304 (L.R. Sherman, MP - Progressive Conservative, Winnipeg South, MB). See also Elizabeth Bymes, letter to the editor, Toronto Star, May 28, 1973, p. 7. ON).

${ }^{77}$ House of Commons Debates (5 April 1966), 3875 (Donald Ross Tolmie, MP - Liberal, Welland,
} 
it for my children. ${ }^{78}$

"All we do by executing ... criminals," argued Warren Allmand, "is descend to the level of the criminal and go backward on the road of civilization."79

It is interesting to note the verbal imagery of movement in these tropes "descend to," be "lower[ed]," "go backward." similar impressions of movement also entered into abolitionist arguments on occasion. Executions, thought one MP, would have given Canadians good cause to remark that "[w]e are debasing all of ourselves, all of society.... [W]e are shaming and degrading ourselves." " "[A]11 Canadians, to some degree, are morally diminished by the doctrine of legal retaliation as employed in the death penalty," argued Lester Pearson. " "[C]apital punishment is morally and socially debasing," said another. ${ }^{83}$ "[D]esire for vengeance ... is not a very elevating motive," asserted an abolitionist citizen. ${ }^{84}$

Many English speakers in many places have used and do use such vocabulary and expressions when portraying some deed or phenomenon as unvirtuous. Accordingly,

${ }^{78}$ House of Commons Debates (29 January 1973), 728 (Peter Reilly, MP - Progressive Conservative, Ottawa West, $O N$ ). Reilly also quoted the quotation given here (and a little more) from Sherman's speech - see p. 727.

${ }^{79}$ House of Commons Debates (23 July 1973), 5902 (Warren Allmand, MP - Liberal, NotreDame-de-Grâce, QC).

${ }^{80}$ I I owe the inspiration for this point at least in part to G.K. Chesterton's somewhat different discussion poking fun at the "material metaphors," such as "'the higher life," that appeared in some people's discussions in substitution for statements containing terms like "good" and "evil" - see G.K. Chesterton, Orthodoxy, introd. Philip Yancey (1908; this ed. New York, NY: Image Books, Doubleday, 2001), $106-107$. South, ON).

${ }^{81}$ House of Commons Debates (12 April 1965), 240 (Robert Temple, MP - Liberal, Hastings

${ }^{82}$ House of Commons Debates (16 November 1967), 4371 (Lester B. Pearson).

${ }^{83}$ House of Commons Debates (22 May 1973), 3982 (Derek Blackburn, MP - NDP, Brant, ON).

${ }^{84}$ LAC, MG32, Series B35 (Walter Gilbert Dinsdale fonds), Volume 79, File 2 - File Title:

"Capital Punishment. General 1973," Betty Waldron to Walter [Dinsdale], February 5, 1973. 
undue significance cannot be assigned to the presence of these expressions in abolitionist rhetoric. Nevertheless, this type of terminology seems to illustrate two perhaps-obvious facets of some abolitionists' ethical mentality. First, such phrases may at times have encouraged some debaters and their listeners to engage in a variety of moral assessment that worked analogously not so much to a gauge with a signal light that either flashed on or remained unlit as a yes-or-no indicator of moral correctness or incorrectness, but rather to a gauge with a dial and needle that revealed greater or lesser moral vitality or putrefaction. Secondly, like a number of the other examples in this section and in some other sections of the thesis, these expressions reveal that some abolitionists remained attuned not simply to the moral correctness or incorrectness of a given policy on the death penalty, nor only to the sorrows or rewards that might arise in others' lives through implementation of the policy. Rather, these debaters also maintained a special interest in the present or forthcoming moral soundness or weakness that they themselves or the citizenry in which they claimed membership did or would possess as a general characteristic. To many abolitionists - and, they suspected, to many of their hearers additional ethical soundness with respect to death-penalty-related issues warranted applause rather than rolled eyes. And additional ethical weakness warranted a statement of regret rather than a yawn.

Admittedly, both the tropes discussed above and broadly similar types of abolitionist claims could feature not only in ethical exhortation, but also in instrumentalist argument. Various examples of such arguments could fit into the discussion in this chapter. But the following item will provide a taste both of the potential for the 
abolitionist rhetoric discussed in the preceding paragraphs to facilitate instrumentalist claims, and also of the ambiguous blend of ethical and instrumental connotations in various abolitionist statements. In a 1966 letter to the editor, a C.B. Whitman suggested that retribution "just does not work," and that capital punishment "just does not make sense." According to "trained investigators," "[c]rime ... is only a symptom, a symptom of a sick society.... Developing a society that has proper consideration for individuals ... will pretty well eliminate crime." As such statements show, for at least the first two paragraphs the letter seemed to be a prime instrumentalist specimen, endowed with discussion of "eliminat[ing] crime," and with reminders of the perpetual absence of such an achievement from any truthful version of the death penalty's résumé. The same melody continued to unfold in the final sentences of the letter, but with vague hints of something additional:

When Southern whites use brutality to degrade the Negroes, who is degraded, the black or the white race? When violence is met with violence, is not the result more violence? Suppose you think the murderer deserves to be murdered, do you agree that by bringing ourselves down to his level, we have done anything to improve our society? Forget about the offender, he has lost out, hanged or not; think about us. We can stand some improving. ${ }^{85}$

Did "bringing ourselves down to his level" qualify as a poor option by virtue of serving as a pointless time filler, or of bumping the domino of "more violence," or of "degrad[ing]" the citizenry? Did the "improving" of which Whitman spoke pertain only to "eliminat[ing] crime" in the end, or also directly to an ethical improvement? One suspects that Whitman had a little of the latter in mind as well.

\footnotetext{
${ }^{85}$ C.B. Whitman, letter to the editor, Toronto Daily Star, February 3, 1966, p. 6.
} 
If ruminations about "pretty well eliminat[ing] crime" rarely surfaced in abolitionist advocacy, many abolitionists did hope that Canadian crime statisticians would find themselves dealing with slightly smaller figures, or at least not with relatively larger ones ${ }^{86}$ And at various times listeners or readers received reminders from abolitionists that the fulfillment of this hope would require no death sentencing, but rather other plans, inputs, and endeavours with respect to criminal justice and other aspects of Canadian life relevant to crime. ${ }^{87}$ But although abolitionists' discussion of such matters certainly brought to light some of the strongly instrumentalist facets of the abolitionist mentality, that does not mean that this mentality made no room for ethical contemplation and decision. Indeed, in some respects abolitionists' moral beliefs could obtain further solidity from such instrumentalist components in their outlook.

This point becomes particularly clear if considered in the light of historian Thomas Haskell's discussion of the eighteenth- and nineteenth-century phenomenon of advocacy for the abolition of slavery. Thanks in large part to the incorporation of capitalist strains - including such phenomena as stronger contract law - into the Western economic melody during this era, the connections between current initiatives, actions deliberately pursued far beyond the immediate present, and eventual economic consequences began to seem clearer and more stable to people of the time. Many more people's economic endeavours now included attempts to milk opportunities that were

\footnotetext{
${ }^{86}$ See, for example, House of Commons Debates (8 June 1966), 6167 (Warren Allmand, MP Liberal, Notre-Dame-de-Grâce, QC).

${ }^{87}$ See, for example, House of Commons Debates (4 April 1966), 3851-3852 (Warren Allmand, MP - Liberal, Notre-Dame-de-Grâce, QC).
} 
expected to blossom at a distant point on the calendar, but which could be tapped through careful thought and systematic steps taken in the meantime. In other words, more thoroughgoing forms of instrumental thinking - although Haskell does not put it in those terms - grew more widespread. Due to the experiences and mentalities that many people had thus acquired, the idea began to emerge strongly in some citizens' minds that the slave trade might well go defunct were it to be confronted by well-devised initiatives of opposition carried out by themselves and like-minded fellows. Moreover, because such initiatives now seemed doable, to some it seemed ethically inexcusable not to pursue them. This was a crucially different viewpoint than had been prevalent before, when no readily workable way of making the slave trade meet its Waterloo had appeared to exist, which had in turn spared most people from concluding that it was ethically incumbent upon themselves or others to work vigorously for abolition. ${ }^{88}$

A few abolitionist comments in the Canadian death-penalty debate reveal the existence of dynamics loosely parallel to some of those that Haskell points out. This is not to say that Canadian abolitionists necessarily exhibited mentalities reflective of capitalism, but rather that the instrumentalist aspects of their outlook allowed them to remember the possibility of establishing non-lethal penal initiatives applicable to killers, and that their belief in the instrumental viability of this option gave them further certainty that their mind's eye was not deceived when it saw the word "unethical" faintly flickering

\footnotetext{
${ }^{88}$ See Thomas L. Haskell, "Capitalism and the Origins of the Humanitarian Sensibility, Part 1," American Historical Review 90, no. 2 (April 1985): 339-361, especially 353, 356, 358-361; see Thomas L. Haskell, "Capitalism and the Origins of the Humanitarian Sensibility, Part 2," American Historical Review 90, no. 3 (June 1985): 547-566.
} 
or firmly stamped across the death penalty. As Pierre Berton argued in 1959:

If, in the last 1959 years we have forgotten the message of the Sermon on the Mount, surely we have learned a few minor skills. We have, in this year of grace, shot satellites into the heavens and fallout into the milk; we have not only invented the thinking man's filter but have also kept the streets safe from polio. Is it too much to hope that we might also keep them safe from darker horrors without staining our hands with blood?

In Berton's eyes, "we have reached a point in time where there are other solutions than the noose." ${ }^{89}$ One portion of the 1973 death-penalty debate in the House of Commons pertained especially to the type of killer whose homicidal deed had formed part of a double blow bestowed on the victim - either rape and murder or kidnapping and murder. ${ }^{90}$ One MP speaking at this time was abolitionist John Gilbert. "Directing my attention to the question of rape and kidnapping," said Gilbert,

I am sure that most people who commit such heinous crimes are mentally or physically ill.... Yet out of our feelings of vengeance we want to impose the death penalty on these people. I do not think it is worthy of us to do so, more especially in view of the enlightened methods we have for treating these people. ${ }^{91}$

Sometimes ethical perspectives found instrumentalist argument to be a teammate rather than a rival.

Among the various topics addressed during the death-penalty debate, debaters' attention gravitated most strongly toward those dealing with deterrence. As emphasized in Chapter 2 , this practical-sounding topic took hold in debaters' discourse for reasons that went

\footnotetext{
${ }^{89}$ Pierre Berton, "In Which I Answer Some Mail," Toronto Daily Star, October 13, 1959, p. 21. For an important related example, see House of Commons Debates (24 March 1966), 3102-3103 (Gérard Pelletier, MP - Liberal, Hochelaga, QC).

${ }^{90}$ See House of Commons Debates (23 July 1973), 5877 (Albanie Morin, MP - Liberal, LouisHébert, $Q C$ ), and subsequent speeches on July 23 and July 24 .

${ }^{9}$ House of Commons Debates (23 July 1973), 5887 (John Gilbert, MP - NDP, Broadview, ON).
} 
beyond the mere attractiveness of practicality in its own right. Certain moral perspectives and arguments, such as anti-retributive claims, also encouraged some debaters to believe that addressing deterrence-related topics would help them to maintain ethical soundness and rhetorical strength in their advocacy. Perhaps paradoxically, moral perspectives helped to promote the discussion of matters that did not at first glance appear so ethically pregnant as many other facets of the debate.

The present chapter has examined moral judgment of a different type within Canadian death-penalty rhetoric — implicit or explicit moral assessments conveyed through discussion that contrasted different types of people. The chapter also demonstrates that some abolitionists considered it strongly dissatisfying to perceive morally contemptible dynamics in their own viewpoints and activities, and expected that other citizens would feel the same way with respect to themselves. Retentionists sometimes believed that to incorporate scriptural assertions or retributive claims into their arguments too plenteously would make their audience less than eager to applaud their case. But some retentionists hoped that if they graced the eyes or ears of their audience with statements about victims, especially "innocent victims," the contrasting reprehensibility of killers' deeds would sink in, with the retentionist perspective perhaps spreading to additional minds as a result. To abolitionists, a certain degree of merit existed in retentionists' exhortation to "show concern for the right people."92 Moreover, some abolitionist statements conveyed the idea that murderers did not qualify as "the right people" quite so well as did other individuals. But abolitionists also believed that

\footnotetext{
${ }^{92}$ G. Rogers, letter to the editor, Globe and Mail, February 27, 1960, p. 6.
} 
those who did number among "the right people" included not only the murder victims, but also all non-murderous Canadians - each in her own right and everyone in aggregate. ${ }^{93}$ Accordingly, abolitionist arguments could suggest that an adequate effort to "show concern for" Canadians writ large would require an anti-capital-punishment policy, in light of the morally putrid anti-nourishment that the citizenry would be metaphorically ingesting if the opposite policy were implemented. The abolitionist effort to show hearers why such allegations of moral unwholesomeness pointed to the truth could also make use of statements contrasting murderers and other citizens, with the former portrayed as "lower" than the non-murderous portion of the public, but with the latter group also warned that it would find itself in the "lower" category too if Canadians decided to walk the retentionist talk and call the executioner into action.

In short, when ethical questions in the death-penalty controversy brought debaters into confrontation with ambiguity, skepticism, or rhetorical barriers, it sometimes seemed easier to make an ethical judgment by pointing to two groups or choices in contrast to one another. And whether ethical issues pertaining to the victim or the murderer seemed straightforward or confounding, abolitionists considered it especially worthwhile to contemplate the types of moral quandaries that spurred them to assess the behaviour and outlook characterizing their own selves - or the citizenry in which they claimed membership.

\footnotetext{
${ }^{93}$ This is not to suggest that retentionists did not typically consider non-murderous non-victims to qualify as "the right people," nor that the above-quoted retentionist phrase about "the right people" had been intended as a reference only to murder victims. The letter writer also discussed "the duty of government to give law-abiding and useful people the absolute limit of protection" - see ibid.
} 


\section{Chapter 4: Responsibility, Psychology, Animality: Images of Human Nature in the Death-Penalty Debate}

On November 22, 1967, MP Heath Macquarrie wrestled with his thoughts out loud in the

House of Commons. In 1966 he had run with the retentionist pack; the 1973 and 1976

bouts of parliamentary voting on the death penalty would see him help the abolitionists

instead. ' At the moment, however, the latter option still bothered him. "We live in a

permissive age," he pointed out.

Sometimes I have the feeling that the motto for our time might be: Nothing is anybody's fault. Sometimes it is the Oedipus complex that is blamed, or the fact that one is a fourth child and the other three were preferred, or else that at Sunday school one had an incompetent teacher. Of course we know there are all sorts of environmental factors, but have we yet reached the stage of viewing man as having no individual responsibility? Do we not consider that when a man takes arms against society he is never responsible for it? ... I think it is degrading to suggest that the human species is nothing more than something which responds to external stimuli. Psychologists say that man in all his actions and reactions is just a little higher than the ape. One can produce predictable patterns of behaviour. But some of us believe also that man is a little lower than the angels and that he wants to be given responsibility.... [S] urely sometimes we must ask the individual to accept responsibility for his action. ${ }^{2}$

In his ruminations about the nature of the human being and the associated implications for the death-penalty debate, Macquarrie had touched on three ways of picturing the human — as responsible agent, psychological being, or animal — that proved useful to those debating capital punishment. Such images served partly as tools to explain why the death penalty lacked deterrent bite or why rehabilitation of killers

${ }^{1}$ For Macquarrie's retentionist vote in 1966 and his abolitionist voting in 1973 and 1976, see Journals of the House of Commons of Canada, $1^{\text {st }}$ Session, $27^{\text {th }}$ Parliament, Volume 113, No. 56 (5 April 1966); Journals of the House of Commons of Canada, $1^{\text {st }}$ Session, $29^{\text {th }}$ Parliament, Volume 119, No. 91 (29 May 1973) and No. 156 (24 October 1973); Journals of the House of Commons of Canada, $1^{\text {st }}$ Session, $30^{\text {th }}$ Parliament, Volume 121, No. 328 (22 June 1976) and No. 341 (14 July 1976).

${ }^{2}$ House of Commons Debates (22 November 1967), 4577 (Heath Macquarrie, MP - Progressive Conservative, Queens, PEI). 
remained unlikely. But these images also served to highlight the foundations of ethical obligation, to question moral assessments, and to express moral judgments obliquely. Although debaters often cast doubt upon the extent of murderers' responsibility for their criminal deeds, Canadians showed little interest in denying human responsibility as such. Indeed, at times abolitionist claims that might have appeared to create question marks about offenders' responsibility served more to highlight the citizenry's obligation to recognize and correct its own crime-fostering choices. Strong concern about the broad philosophical implications of abolitionism with respect to free will existed among a limited group of citizens, many of them conservative Christians. These citizens suspected that those who bought into the thought patterns associated with abolition might end up considering claims about free will and moral duty to be inapplicable to any human being, whether or not he were an offender. ${ }^{3}$ Both abolitionists and retentionists occasionally used popularized psychological ideas in their efforts to clarify or verbally work around the uncertainties concerning deterrence and rehabilitation. In addition, evocations of human psychology and of humanity's ambivalent animal status allowed the abolitionist camp to encourage wariness among Canadians toward their own human affinity for vengefulness and penal harshness, and to represent the human condition as centring on profound yet tenuous historical progress in social and moral life. ${ }^{4}$ Some retentionists, on

\footnotetext{
${ }^{3}$ See Chandler, Capital Punishment in Canada, 22-23 for Chandler's brief discussion of retentionists' perspective on free will with respect to the death-penalty controversy. Although my argument about Canadians' perspectives on responsibility diverges in important ways from his very brief analysis, there are important similarities between his description and my final sentence above.

4n the phrase "progress in social and moral life," I am using language very close to that of at least one of my primary sources: MP John Matheson spoke of "[s]ocial and moral progress" - House of Commons Debates (4 April 1966), 3801 (John Matheson, MP - Liberal, Leeds, ON).
} 
the other hand, used verbal images of animality both to hint at murderers' moral transgression and to portray them as amorally unreformable and concretely dangerous, and thus as threats to be neutralized through execution. In effect, such retentionists put the image of human animality to work in their efforts both to keep the door open for a form of low-visibility retributive thinking and to portray capital punishment as achieving a practical result demanded by the exigencies of murderers' continuing dangerousness.

Various abolitionists pointed to the recent or more distant past to argue that when the death penalty had gone into retirement in other societies, subsequent events had given the respective citizenries no statistical cause for greater fear of murder. If there were exceptions, that was because some change had also occurred in one of the many nondeath-penalty-related ingredients out of which murder rates genuinely do materialize. Such statistical claims gave many abolitionists confidence to assert that the state could boast no greater ability to deter homicide when brandishing lethal consequences than when employing other sentences. ${ }^{5}$ But by no means did Canadians who argued about deterrence talk only about statistics. To many citizens, abolitionists' attempts to dissociate capital punishment from genuine deterrence triggered a mental warning signal associated with implausible claims. As one retentionist noted, "it is only common sense

\footnotetext{
${ }^{5}$ See, for example, House of Commons Debates (18 February 1960), 1198-1999 (Arthur Maloney, MP - Progressive Conservative, Parkdale, ON); (9 November 1967), 4078-4079 (Larry Pennell, MP Liberal, Brant-Haldimand, ON); (9 November 1967), 4087-4088 (Andrew Brewin, MP - NDP, Greenwood, ON); Cheryl-Ann White on behalf of Youth Corps Prison group and Bob Carty on behalf of Youth Corps staff and directors, letter to the editor, Toronto Star, January 25, 1973, p. 7; Warren Allmand, "No, Says Solicitor-General Warren Allmand" [part of "Should We Hang Police-Killers?"], Toronto Star, April 4, 1975, p. B3.
} 
to conclude that capital punishment must be a deterrent for many persons."' Moreover, numerous debaters of both retentionist and abolitionist stripe shied away from pledging obedience to purported statistical lessons. "Anyone can make statistics say whatever they like," claimed one MP, baldly stating a theme that had emerged frequently in the House of Commons. ${ }^{7}$ Many wanted not only numeric data, but also a satisfying mental picture of how persons who were tempted to commit murder thought, felt, and ultimately came either to do the deed or repulse the urge.

Accordingly, the mental and emotional phenomena associated with desire, deed, and deterrence received plentiful attention during debate, with debaters' patterns of reasoning often following precedents set long ago. ${ }^{8}$ Sometimes abolitionist arguments posited that when a cloudburst of emotion made a killer veer abruptly toward the homicidal act, he either forgot that he was making himself liable to execution or did not consider the disincentive compelling. ${ }^{9}$ In addition, some argued that when a murderous

\footnotetext{
${ }^{6}$ House of Commons Debates (24 May 1961), 5307 (William Joseph Browne, MP - Progressive Conservative, St. John's West, NF).

${ }^{7}$ House of Commons Debates (7 June 1976), 14213 (Paul Dick, MP - Progressive Conservative, Lanark-Renfrew-Carleton, ON). For a few examples of similar claims, see House of Commons Debates (24 March 1966), 3098 (Jack McIntosh, MP - Progressive Conservative, Swift Current-Maple Creek, SK); (28 March 1966), 3302-3303 (Raymond Rock, MP - Liberal, Jacques-Cartier-Lasalle, QC); (29 January 1973), 757 (John Gilbert, MP - NDP, Broadview, ON). For another example of general skepticism towards statistics, see House of Commons Debates (20 February 1973), 1483 (Ed Nelson, MP - NDP, BurnabySeymour, BC). David Chandler notes the same critique of statistics, although at least on the page cited here, it is not clear whether he perceived abolitionists as offering any criticism of this type - see Chandler, Capital Punishment in Canada, 27.

${ }^{8}$ For brief discussion of some such precedents from long ago, see Banner, Death Penalty: An American History, 216-217, and Evans, Rituals of Retribution, 906. This latter source summarizes typical abolitionist reasoning in basically the same manner as (although more concisely than) I do in the remainder of the paragraph above.

9 Along these lines, see House of Commons Debates (16 February 1962), 968 (Harold Winch, MP - NDP, Vancouver East, BC); (4 April 1966), 3837 (Jean-Eudes, Dubé, MP - Liberal, RestigoucheMadawaska, NB); (9 November 1967), 4080 (Larry Pennell, MP - Liberal, Brant-Haldimand, ON); (18 October 1973), 7011-7012 (Frank Howard, MP - NDP, Skeena, BC); Rev. Al Farthing, letter to the editor, Toronto Star, January 29, 1973, p. 7.
} 
scheme materialized in the mind of a citizen who then followed through with the idea calmly, the killer saw future execution as only a hypothetical possibility. In his eyes, that possibility was bound to remain merely hypothetical since the manner in which he had done the deed supposedly gave the authorities no real chance to determine his identity or location. ${ }^{10}$ For these or similar reasons, abolitionist arguments sometimes suggested that almost no variety of murderer perceived his crime or his circumstances in a manner that would allow death-penalty law to do its deterrent work to the degree anticipated. ${ }^{11}$

Such reasoning failed to satisfy retentionists, for it dealt only with persons who did in fact end up committing murder - persons who by definition had escaped the clutches of deterrence. Retentionists assumed that another type of individual existed and deserved debaters' attention - the person who faced genuine temptation to kill but did not obey the urge. Such persons' non-action probably exemplified genuine deterrent dynamics, believed retentionists, but if so, these could-have-been-offenders also constituted one of the statisticians' big problems. After all, any attempt to enumerate the people in this category would fail, barring the unlikely possibility that such individuals would be willing to identify themselves when questioned. ${ }^{12}$ But retentionists continued to

\footnotetext{
${ }^{10}$ Along these lines, see House of Commons Debates (4 April 1966), 3837 (Jean-Eudes, Dubé, MP - Liberal, Restigouche-Madawaska, NB); (9 November 1967), 4080 (Larry Pennell, MP - Liberal, BrantHaldimand, ON); (18 October 1973), $7011-7012$ (Frank Howard, MP - NDP, Skeena, BC); Rev. Al Farthing, letter to the editor, Toronto Star, January 29, 1973, p. 7.

${ }^{11}$ See A.G. Wakefield, letter to the editor, Globe and Mail, March 3, 1960, p. 6; House of Commons Debates (4 April 1966), 3837 (Jean-Eudes, Dubé, MP - Liberal, Restigouche-Madawaska, NB); (9 November 1967), 4080 (Larry Pennell, MP - Liberal, Brant-Haldimand, ON); (18 October 1973), 70117012 (Frank Howard, MP - NDP, Skeena, BC).

${ }^{12}$ See, for example, House of Commons Debates (28 March 1966), 3312 (John Angus MacLean, MP - Progressive Conservative, Queen's, PEI); (5 April 1966), 3866 (Gordon Churchill, MP - Progressive Conservative, Winnipeg South Centre, MB); (5 April 1966), 3885 (Marcel Lambert, MP - Progressive Conservative, Edmonton West, AB); (26 January 1973), 694 (Erik Nielsen, MP - Progressive Conservative, Yukon, YT). Sometimes these issues that retentionists liked to point out also received explicit recognition
} 
believe that, in the likely event that such persons did in fact exist, capital-punishment law almost certainly provided at least one of the ingredients in their decision not to kill. As MP Douglas Harkness said, perhaps thinking of his own World War II past, "No one who has had experience in a war and has seen men under fire can fail to be convinced that the fear of death is the greatest fear there is so far as the vast majority of people are

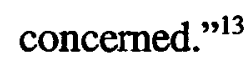

As historian Stuart Banner has observed with respect to the American scene, "competing understandings of human nature" had historically underlain such disputes. ${ }^{14}$ That dynamic also seems to have obtained in the case of the debate considered in this thesis. ${ }^{15}$ Occasionally debaters' language made it sound as if they disagreed more specifically about which humans had which nature, or perhaps about which humans had which nature at which time. If the statistician's workbook or the psychiatrist's couch could not provide accurate insight into deterrence, some retentionists thought that a mirror would do the job. To assess deterrence, said Douglas Harkness, "I suggest that what we have to rely on chiefly is the application of common sense to our own reactions

\footnotetext{
from abolitionists, including at least one of the debaters who used the sort of abolitionist arguments described earlier in the paragraph — see House of Commons Debates (9 November 1967), 4078 (Larry Pennell, MP - Liberal, Brant-Haldimand, ON).

${ }^{13}$ House of Commons Debates (14 November 1967), 4263 (Douglas Harkness, MP - Progressive Conservative, Calgary North, AB). On Harkness' service in the war, see The Canadian Who's Who, vol. XI, 1967-1969 (Toronto: Who's Who Canadian Publications, 1969), s.v. "Harkness, Lieut.-Col. the Hon. Douglas Scott." For other examples of MPs who linked lessons taken from their military past with the claim of genuine deterrence through capital punishment, see House of Commons Debates (10 November 1967), 4161 (Gordon Churchill, MP - Progressive Conservative, Winnipeg South Centre, MB); (26 January 1973), 695 (Erik Nielsen, MP - Progressive Conservative, Yukon, YT).

${ }^{14}$ Banner, Death Penalty: An American History, 216; along similar lines, see Masur, Rites of Execution, 153-154.

${ }^{15}$ David Chandler suggests this; for his observations on the matter, see Chandler, Capital Punishment in Canada, 22-23, 28-29.
} 
and the reactions of other people we have observed throughout our lives in connection with the effect of deterrents on them." He added, "I reject the idea that there is a criminal mind as such. I believe that all human beings react to basic situations in the same way and that criminals have the same reactions as the rest of us." "I do not agree that punishment is not a deterrent," declared another retentionist. "It certainly is for me, and I am a human being."17

But some abolitionists doubted that either their retentionist opponents or most other citizens would ever qualify as genuine candidates to commit murder - provided, at least, that they did not cease to be "normal" for a time. ${ }^{18}$ As at least a few abolitionists saw it, those who really would engage in this crime frequently stood apart as "abnormal" individuals, at least while in murderous mode. ${ }^{19}$ "The fear of death will deter normal men but when a man commits murder, is he normal?" asked Tommy Douglas. He believed that the correct answer would typically be in the negative. "An individual who has become so mentally sick that he will take another life or ravage a child is certainly not a

\footnotetext{
${ }^{16}$ House of Commons Debates (14 November 1967), 4263 (Douglas Harkness, MP - Progressive Conservative, Calgary North, AB).

${ }^{17}$ House of Commons Debates (14 November 1967), 4292 (Jean Wadds, MP - Progressive Conservative, Grenville-Dundas, ON).

${ }^{18}$ For widely varied comments that seem to hint at different parts of what I have described in this sentence, see House of Commons Debates (23 March 1966), 3070-3071 (Terence Nugent, MP Progressive Conservative, Edmonton-Strathcona, AB); (9 November 1967), 4079 (Larry Pennell, MP Liberal, Brant-Haldimand, ON); (6 May 1976), 13259 (John Gilbert, MP - NDP, Broadview, ON). For more direct discussion of the type of idea I have here attributed to some abolitionists, see the largely scholarly discussion in Fattah, Study of the Deterrent Effect, 24-27.

${ }^{19}$ For statements that contain ideas at least partly in alignment with my description here, see Charlotte Hollander, letter to the editor, Toronto Daily Star, November 28, 1959, p. 6; House of Commons Debates (23 March 1966), 3070-3071 (Terence Nugent, MP - Progressive Conservative, EdmontonStrathcona, AB); (29 January 1973), 739 (B. Keith Penner, MP - Liberal, Thunder Bay, ON).
} 
mentally healthy or normal individual."20 Deterrence through death sentencing simply

failed to materialize, affirmed another, for

murderers are not normal people, for the most part. Most of them are driven by forces of emotion, or outright insanity even.... I am not necessarily making a plea that such people ought to be pitied; it is a demand that we understand the circumstances in which they are, for the most part, incapable of reacting and reasoning like normal human beings. ${ }^{21}$

Indeed, the distinction between people who would murder and more "normal" people came into play in more than one aspect of the death-penalty debate. This duality appeared not only in the discussion of the processes through which deterrence did or did not occur, but also in talk about rehabilitation and parole. ${ }^{22}$ And it also left its mark upon discussions of moral responsibility - the moral responsibility both of offenders and of citizens in general.

\section{Freedom and the Responsible Human}

Stuart Banner's study suggests that understanding capital punishment in the United States requires attention to the place that the notion of free will has occupied in American culture. When we consider the history of American capital punishment from a panoramic vantage point, we can discern a rough positive correlation between the historically varying degree of affirmation Americans have given the death penalty and their historically varying inclination to see free will as a genuine facet of criminals' character.

\footnotetext{
${ }^{20}$ House of Commons Debates (5 April 1966), 3868-3869 (Tommy Douglas, MP - NDP, BurnabyCoquitlam, BC).

${ }^{21}$ House of Commons Debates (30 January 1973), 806 (Doug Rowland, MP - NDP, Selkirk, MB).

${ }^{22}$ See, for example, House of Commons Debates (9 November 1967), 4113-4117 (George Hees, MP - Progressive Conservative, Northumberland, ON). Note that this speech seems to apply the term "abnormal" to individuals involved in "cold-blooded, premeditated" homicide.
} 
In Banner's estimation, this rough correlation reflects a causal dynamic: citizens'

readiness or reluctance to believe that criminal conduct followed trajectories plotted by free will has played a significant role in generating retentionist or abolitionist loyalties. He believes that this pattern will probably persist on the American scene. ${ }^{23}$

Determining whether Banner's observations apply well in the Canadian setting would require the examination of a much more lengthy chronological period than that covered by the present study. However, the sources investigated here certainly do suggest that many abolitionists preferred to account for murder largely without reference to offenders' own decision-making. Tommy Douglas was far from the only Canadian inclined to find clues of mental illness when figuratively surveying a murder scene. In a letter discussing a notorious pedophile and murderer, one citizen posed a question to her fellow Star readers: "How long will it be before we are sufficiently civilized to treat persons like Dion as ill, and not as criminals?"24 The suspicion of illness persisted in the case of less sensational murders as well. "[[]sn't everyone who kills deliberately insane in some respect?" asked a Globe reader. ${ }^{25}$ Also, in many debaters' eyes, the events, persons, and other phenomena with which society brought the offender into contact as he

\footnotetext{
${ }^{23}$ See Banner, Death Penalty: An American History, 14, 118-121, 208-215, 240, 282-283, 310 311; see Richard W. Garnett, "Final Justice," review of The Death Penalty, by Stuart Banner, and The Contradictions of American Capital Punishment, by Franklin E. Zimring, America: The National Catholic Weekly 189, no. 13 (October 27, 2003), http://www.americamagazine.org/content/article.cfm?article_id=3244 (accessed April 29, 2006).

${ }^{24}$ (Mrs.) E. Rutherford, letter to the editor, Toronto Daily Star, December 23, 1963, p. 4. Similarly, see Frank A. Murphy, letter to the editor, Toronto Daily Star, December 17, 1963, p. 6.

${ }^{25}$ (Mrs.) George A. Bowman, letter to the editor, Globe and Mail, September 15, 1965. For just some of the other examples of the tendency to see murder and mental illness as intersecting phenomena, see Charlotte Hollander, letter to the editor, Toronto Daily Star, November 28, 1959, p. 6; Paul Pfalzner, letter to the editor, Globe and Mail, December 16, 1959, p. 6; Mrs. E.T. O'Malley, letter to the editor, Globe and Mail, January 1, 1963, p. 6; J.I. Johnstone, letter to the editor, Toronto Daily Star, April 15, 1966, p. 6; Janet Money, letter to the editor, Toronto Star, July 23, 1973, p. 7.
} 
walked his life's road did much to steer him down the side-route to murder, or at least to make it the path of least resistance. "Surely, in this so-called civilized age," wrote one citizen, "it is apparent that the causes of murder lie in the early faulty conditioning of these criminals and is more a sickness to be treated, than grounds for vindictive reprisal." ${ }^{26}$ Another letter writer believed that "[ $[t]$ he cause of crime is parental delinquency rather than in the criminal himself' - a sentiment quite in line with the postwar perspective on parenting, childhood, and the materialization of the traits that would undergird a given individual's habits and deeds. ${ }^{27}$ In sum, abolitionist argument did not typically dwell on steps the offender had deliberately taken in the process of legal transgression. A number of abolitionists chose instead to assign primary significance to alternative explanations of the offensive act.

Abolitionist resistance to the notion that most of the blame for offences belonged to offenders did not necessarily take the form of confident blanket assertions. In at least some cases, abolitionist statements on the issue expressed some ambivalence, portraying offenders' responsibility as unclear rather than as nonexistent. Jean Marchand could speak, on the one hand, of some beleaguered individuals as "the product of our society" whose problems thus reflected "our own incompetence." Still, he leaned toward belief in human agency: "It is possible, it is even certain, that some criminals are responsible." But determining which ones qualified as such created a major obstacle that ruled out the

\footnotetext{
${ }^{26}$ Betty Pellier, letter to the editor, Toronto Daily Star, December 20, 1962, p. 6 (p. 99 in digital archive)

${ }^{27}$ Ernest W. Archer, letter to the editor, Globe and Mail, January 3, 1963, p. 6. See Owram, Born at the Right Time, 32-52.
} 
clarity and certainty that ought to be prerequisites for execution. ${ }^{28}$ Another MP, LouisPaul Neveu, declared that " $[t]$ he death penalty is based on a metaphysical concept of human freedom, whereas according to social science, an offender usually does not enjoy complete freedom." In dealing with what "usually" obtained and discussing the indeterminate zone between minimal and "complete freedom," Neveu did not have to go so far as to quantify the responsibility of murderers as falling between negligible and none. Instead, he could make a point similar to Marchand's: "Human justice cannot assess individual responsibility positively."29

Abolitionists may have often felt uncertain about whether Canadians could realistically expect a killer to have turned away from the homicidal act, or about how closely the moral black mark accompanying murder should be associated with the killer himself. But such uncertainty did not cause them to stop perceiving moral goals or requirements as pertinent to their own conduct, or to that of other non-offenders. Indeed, sometimes the suggestion that murderers should face less blame for their actions served less as an attempt to pare down human responsibility than as an effort to highlight the moral obligations that other persons needed to recognize and fulfill. A few abolitionists who emphasized society's role in facilitating crime may essentially have been attempting, as Macquarrie feared, to suggest that "[n]othing is anybody's fault,"30 but some abolitionist statements implicitly emphasized non-offending Canadians' joint duty to take

\footnotetext{
${ }^{28}$ House of Commons Debates (28 March 1966), 3279-3280 (Jean Marchand, MP - Liberal, Quebec West, QC). The quotes are from p. 3280.

${ }^{29}$ House of Commons Debates (28 March 1966), 3287 (Louis-Paul Neveu, MP - Liberal, Shefford, QC). See also p. 3288.

${ }^{30}$ House of Commons Debates (22 November 1967), 4577 (Heath Macquarrie, MP - Progressive Conservative, Queens, PEI).
} 
steps together to address crime-related problems created by societal commission or omission. "The man society executes for a crime is in part society's own child," argued one letter writer. Such an offender "is conditioned by what society has done or failed to do for him." However, this writer did not simply want to make the offender look a little better and society a little worse; instead, her observation led her to discuss multiple initiatives by which society could clean up its act with respect to the imprint it left upon its citizens. The writer did not consider such initiatives merely optional, but rather spoke of what "[w]e must" do and what "should be" done. In this particular letter, then, lawabiding Canadians' responsibility received as much or more emphasis than did any suggestion about the offender's partial non-responsibility. ${ }^{31}$ "Killing murderers and thus sweeping them under the rug," declared another letter, "has prevented us in the past from feeling the weight of responsibility for those teachings and conditions in our midst which can cause an innocent child to grow into a murderous adult.. ${ }^{.32}$

Along related lines, MP Max Saltsman spoke of a particular boy who had seemed to his grandmother to fit the profile of the murderer-in-germination, and whose social needs seemed to call for intervention by a public agency. Unfortunately, resource shortages had stood in the way of such aid. In the event that such an individual actually did end up committing homicide, reflected Saltsman, "who will be responsible in that case; will it be the boy who becomes a murderer, will it be the mother or will it be society? When that 12 year old boy needed help he could not find it, so surely society has

\footnotetext{
${ }^{31}$ Margaret Mandley, letter to the editor, Toronto Daily Star, December 14, 1962, p. 6 (p. 99 in digital archive). In the original letter, "We must" appears within a short bit of text that is bold-faced.

${ }^{32}$ (Mrs.) Margaret Sorensen, letter to the editor, Globe and Mail, December 2, 1967, p. 6.
} 
to bear some share of the blame." Saltsman was not suggesting that the nation should helplessly hang its head in shame; he wanted society to set its shoulder to a task: "If we are serious about this matter of protecting society," then

[w]e must remove some of the environmental circumstances that create an atmosphere in which this takes place, and we must concentrate much more on providing assistance to young people who are disturbed in order to make sure that society is adequately protected in the future. ${ }^{33}$

Admittedly, Saltsman tended not to focus solely on moral matters when addressing capital punishment, but also to try to arouse his listeners' appetite for the pursuit of smart, instrumentally apt initiatives in criminal justice. ${ }^{34}$ Probably his above recommendation illustrated this tendency too. But the scent of moral urgency wafted through his discussion as well. ${ }^{35}$ In short, if various abolitionists could not confidently place an offender in the moral hot seat by himself, some of them were quite ready to believe that they and their fellow citizens should, to a greater degree than traditionally practiced, recognize themselves to be under obligation to deal with the problems revealed by homicide. ${ }^{36}$

${ }^{33}$ House of Commons Debates (16 May 1973), 3841-3842 (Max Saltsman, MP - NDP, Waterloo, ON). For additional context that perhaps brings out an additional element in these remarks of Saltsman's but which I have not emphasized here, see House of Commons Debates (15 May 1973), 3772-3773 (Max Saltsman, MP - NDP, Waterloo, ON).

${ }^{34}$ See House of Commons Debates (28 March 1966), 3307-3309 (Max Saltsman, MP - NDP, Waterloo South, ON).

${ }^{35}$ See House of Commons Debates (16 May 1973), 3841-3842 (Max Saltsman, MP - NDP, Waterloo-Cambridge, ON).

${ }^{36}$ For other statements revealing a similar dynamic, although to varying degrees, concerning the responsibilities of society, see House of Commons Debates (28 March 1966), 3314 (Bryce Mackasey, MP Liberal, Verdun, QC); (22 May 1973), 3984 (Derek Blackburn, MP - NDP, Brant, ON); LAC, MG32, Series B35 (Walter Gilbert Dinsdale fonds), Volume 79, File 2 - File Title: "Capital Punishment. General 1973," Cheryl-Ann White on behalf of Youth Corps Prison Group and Bob Carty on behalf of Youth Corps Staff and Directors to "Dear Sir," January 18, 1973; and File 3 - File Title: "Capital Punishment. General 1975," J.W. Simmons, Director, and Ron McIntosh, Chairman [of the Board of Directors], United Church Halfway Homes to Warren Allmand, June 1, 1975, and Anna Woods to W.G. Dinsdale, June 3, 1975; House of Commons Debates (25 May 1976), 13802 (Marke Raines, MP - Liberal, Burnaby-Seymour, BC). 
From one perspective, we could possibly extrapolate from the admittedly lessthan-definitive evidence in the preceding paragraphs and begin to see reason for cognitive dissonance in some abolitionists' possibly divergent assumptions about the moral responsibility of murderers, on the one hand, and of non-offending citizens, on the other. At the same time, it is possible that the thinking of at least many such abolitionists would actually seem quite coherent if it were to be analyzed in detail. But in any case, as has undoubtedly been observed by other writers, the power of cognitive dissonance to capture people's attention should not be overestimated. While it is tempting to think that contemplation of crime and responsibility naturally leads to analysis of the volitional capacities or lack thereof that characterize all persons, it does not appear that most Canadians necessarily thought along such lines. A precedent for not doing so had existed for at least a generation. In the interwar and early postwar years, Canadians had tended to analyze the blameworthiness of a given murderer not simply by reference to principles of intention, choice, and action that they considered applicable to any person, but also by reference to presupposed characteristics of the persons within a specific social category to which the killer belonged, such as his or her ethnic group or gender. ${ }^{37}$

Moreover, in the period covered by the present study, it is not clear that those Canadians who did contemplate the relationship between murder, capital punishment, and free will necessarily proceeded along the paths of reasoning that philosophical analysis might suggest. Writer Eric Nicol reputedly observed that "[w]e may wonder how a

\footnotetext{
${ }^{37}$ See White-Mair, "Negotiating Responsibility," i-iii, 4-6, 8-10, 12, 15-17, 110-112, 159-161, 250-254.
} 
society can become so dichotomous in its philosophy as to see determinism as the main factor in illness, unemployment, divorce, abortion and a host of other crying shames, yet sees [sic] the killing of a policeman as 100 per cent an act of free will." ${ }^{\text {"38 }}$ Nicol was exaggerating Canadians' affinity for dichotomies: most citizens probably did not consider a criminal act to be " 100 per cent an act of free will." Nor did they think the polar opposite. One writer might claim baldly that "[f]ree will is a myth long defunct," 39 but the mainstream attitude found better expression in the abolitionist statement which suggested that "[m]en's actions are motivated through a combination of 'free will' and 'determinism." 40 Nor did all Canadians necessarily agree with Nicol that execution should not occur when phenomena other than the murderer's own choices qualified as major antecedents of his murderous act. "Which, in your opinion, is more to blame for crime and lawlessness in this country — the individual or society?" asked two Gallup polls in the early and mid-1970s. The majority of respondents selected the latter option. ${ }^{41}$

${ }^{38}$ Eric Nicol, quoted in House of Commons Debates (5 May 1976), 13221 (Ursula Appolloni, MP - Liberal, York South, ON). I have not identified the Nicol writing from which Appolloni was quoting. For one of Nicol's other anti-death-penalty efforts, see Eric Nicol, "If Hangings Continue - Make Them Public," Maclean's Magazine 72, no. 16 (August 1, 1959): 7, 41-42.

${ }^{39} \mathrm{C}$. Mortimer Bezeau, letter to the editor, Globe and Mail, March 1, 1960, p. 6.

${ }^{40}$ LAC, MG32, Series B35 (Walter Gilbert Dinsdale fonds), Volume 78, File 12 - File Title: "Capital Punishment. General. n.d.; 1953-1967," "Capital Punishment," January 29, 1960. It is not clear who authored this three-page document. However, what appears to be a revised version of the same document (but which does not contain the particular sentence quoted above) appeared again in MPs' mailboxes five years later - see LAC, MG32, Series C31 (Heath Nelson Macquarrie fonds), Volume 42, File 31 - File Title: "Capital Punishment. 1965," "Capital Punishment," brief from the Social Action Committee of the Unitarian Congregation of South Peel, Port Credit, Ontario, attached to Arnold Thaw, Minister, and Arthur Harris, Chairman, Social Action Committee, Unitarian Congregation of South Peel to All Members of Parliament, April 27, 1965.

${ }^{41}$ Canadian Institute of Public Opinion, "Crime Blamed on Society Rather Than the Individual," news release (The Gallup Report), April 7, 1971; Canadian Institute of Public Opinion, "61\% Blame Society for Crime Rather Than the Individual," news release (The Gallup Report), March 17, 1976. The percentages identifying "society" as the greater offender were $52 \%$ and $61 \%$, respectively; the percentages selecting "the individual" were $27 \%$ and $25 \%$. Ezzat Fattah points out the first of these polls in conjunction with an early-1970s capital-punishment poll, much as I am doing here - see Fattah, Study of a Social 
Meanwhile, other Gallup polls in the 1970s suggested that the retention of the death penalty won the affirmation of the majority of the population. ${ }^{42}$ Nicol would have thought that this combination of stances on the two issues smelled all wrong. ${ }^{43}$ But if it could be difficult to achieve a neat-and-tidy theoretical analysis of human responsibility, most postwar Canadians managed not to let the difficulty bother them too deeply, or at least not to let it become too visible in the death-penalty debate.

Some individuals stood out as exceptions to this generalization. Such debaters suspected, to their dismay, that the thought patterns that would steer Canadians toward abolition might also carry the people on toward philosophical territory in which human individuals in general would be assumed not to be controlling shareholders, as it were, in the process whereby their own choices were determined. Accordingly, each individual would also be free from the moral requirements that accompanied such a controlling stake. $^{44}$ Worries of this type surfaced in the parliamentary debate of 1960 . On February 25, MP Grant Campbell warned that

we are uncritically swallowing whole the half-baked ideas of the psychologists and sociologists that anyone who commits a murder must be sick; that the action

Attitude, 67.

${ }^{42}$ See Fattah, Study of a Social Attitude, 4-5, 67; see also Canadian Institute of Public Opinion, "48\% Want Capital Punishment: Better Law \& Order Not Enough," news release (The Gallup Report), March 3, 1976; Canadian Institute of Public Opinion, "Most Don't Know MP's Vote on Capital Punishment," news release (The Gallup Report), September 22, 1976; Canadian Institute of Public Opinion, "Large Majority of Canadians Still Favor Capital Punishment," news release (The Gallup Report), August 6,1977 . Note that the March 3, 1976 poll measured 48\% affirmation of the death penalty even "[i]f we can achieve better law \& order" without it. The percentage of the population wanting death sentencing in the actual circurnstances of 1976 was probably substantially higher - see the discussion in Chapter 5.

${ }^{43}$ See the quotation from Nicol in House of Commons Debates (5 May 1976), 13221 (Ursula Appolloni, MP - Liberal, York South, ON). Again, I have not identified the Nicol writing from which Appolloni was quoting.

${ }^{44} \mathrm{My}$ description here is in many respects similar to Chandler's - see Chandler, Capital Punishment in Canada, 22-23. 
of such people is due entirely to their heredity and environment and that, therefore, they are not responsible.

There is a certain truth in the notion of corporate guilt, and society must share part of the blame for any antisocial actions. We are all the victims of our heredity and our environment while we dwell in time and space....

Despite these factors there must remain some residue of free will or there is no responsibility. If we have no responsibility, we are not men but automatons. There is only one sense in which this grim predestination is true, and that is the Calvinist and, indeed, Catholic belief that an omnipotent God must know our ultimate destiny before we are even conceived. This dull determinism which negates all responsibility reduces our humanity and cannot be accepted by any civilization which is to survive. ${ }^{45}$

"Surely we cannot say that all people who commit crimes are sick people," urged MP

Paul Martineau later the same day. He sensed "confusion in our thinking regarding right and wrong and concerning man as a responsible person, which is the distinguishing mark of man as compared with the other creatures of this earth." Simard expressed similar discomfort. He admitted that "many criminals may not be entirely responsible or even, in a few cases, not responsible at all," but "the campaign against capital punishment should not spread the conviction that all guilty people are robots or sick people. That would be casting on the greatness of man a reflection of the utmost gravity."47

The three MPs just mentioned were probably all religious men. Campbell's speech discussed religious issues, although its sometimes-confusing wording makes his

\footnotetext{
${ }^{45}$ House of Commons Debates (25 February 1960), 1441-1442 (Grant Campbell, MP - Progressive Conservative, Stormont, $O N)$.

${ }^{46}$ House of Commons Debates (25 February 1960), 1450 (Paul Martineau, MP - Progressive Conservative, Pontiac-Témiscamingue, QC).

${ }^{47}$ House of Commons Debates (23 March 1966), 3084 (Alcide Simard, MP - Ralliement Créditiste, Lac-Saint-Jean, QC).
} 
own religious stance less than obvious to the reader. ${ }^{48}$ Martineau was a fourth-degree Knight of Columbus, while Simard's speech dripped with religious analysis. ${ }^{49}$ But if Campbell and Simard added plenty of qualifiers to their affirmations of human responsibility, certain other religious retentionists made the case more forcefully. C.L. Thompson, a minister from the Ontario community of Fenelon Falls, complained that the whole fibre and framework of the Divine Justice and Moral Laws of God are being questioned, ridiculed, and even prostituted for the more 'popular' and 'humane' methods as propagated by our modern psychiatrists.

They claim to possess the capacity to define the sin of murder as being merely a case of mental sickness and proceed forthwith to prescribe a remedy for the 'patient.'

To Thompson, the human makeup differed markedly from the model implied by such perspectives: "Man is still a responsible individual human entity." ${ }^{\circ 0}$ Perhaps Thompson had been talking to E.L.H. Taylor, who at the time was also serving in Fenelon Falls. ${ }^{51}$ In any case, Taylor would have shared his views. A Taylor article published a few months later touched on similar concerns, and a later essay argued the point still more vigorously. ${ }^{52}$ MP Dean Whiteway unapologetically defended the same perspective in 1976:

\footnotetext{
${ }^{48}$ House of Commons Debates (25 February 1960), 1441-1443 (Grant Campbell, MP - Progressive Conservative, Stormont, ON).

${ }^{49}$ See The Canadian Who's Who, vol. VIII, 1958-1960 (Toronto: Trans-Canada Press, 1960), s.v. "Martineau, Paul"; see also Who's Who in Canada, 1962-63, ed. B.M. Greene, associate ed. G.W. Stratton, (Toronto: International Press Limited, 1962), 46; see House of Commons Debates (23 March 1966), 30803084 (Alcide Simard, MP - Ralliement Créditiste, Lac-Saint-Jean, QC).

${ }^{50}$ C.L. Thompson, letter to the editor, Toronto Daily Star, February 23, 1960, p. 4. For evidence that Thompson was a minister, see (Rev.) C.L. Thompson, letter to the editor, Globe and Mail, February 23, 1960 , p. 6. This letter is a longer variant of the letter appearing in the Daily Star.

${ }^{51}$ See (Rev.) E.L.H. Taylor, letter to the editor, Globe and Mail, January 9, 1960, p. 6; Taylor, "Should the Death Penalty Be Retained in Canada?", 17.

${ }^{52}$ See Taylor, "Should the Death Penalty Be Retained in Canada?", 22-24; see E.L.H. Taylor, "Medicine or Morals as the Basis of Justice and Law," in Essays on the Death Penalty, ed. T. Robert Ingram, 81-102 (1963; repr., Houston, TX: St. Thomas Press, 1971).
} 
I reject the views of the environmentalists and behaviourists such as B.F. Skinner, who ... reduce all human action as the mere product of previous experience. They suggest ... that, in a sense, it is society that is wrong, not the individual who transgresses the law. I reject that approach which disregards human responsibility. I believe in the biblical position that we are created in the image of God and with the knowledge of good and evil, and that we have the choice to do right or wrong. ${ }^{53}$

This is not to say that only Christians believed in free will in the postwar world. When another ordained Anglican, MP Reg Stackhouse, raised his retentionist voice in the House of Commons, he was happy to name Jean-Paul Sartre as an ally in defence of "personal responsibility." But there is little doubt that the theologian Stackhouse extolled "personal responsibility" more on the strength of "the biblical ethic" than out of any loyalty to existentialist thought. ${ }^{54}$

Theological commitment to free will and responsibility occasionally surfaced within abolitionist ranks as well. In 1960, the United Church of Canada released a document discussing "alternatives to capital punishment," a topic with which a UCC committee had concerned itself in the wake of the Church's endorsement of abolition in

\footnotetext{
${ }^{53}$ House of Commons Debates (8 June 1976), 14258 (but see also 14256) (Dean Whiteway, MP Progressive Conservative, Selkirk, MB).

${ }^{54}$ See House of Commons Debates (14 May 1973), 3742 (Reg Stackhouse, MP - Progressive Conservative, Scarborough East, ON). On Stackhouse's membership in the clergy and his training in and teaching of academic theology, see footnote 74 in Chapter 2.

For other examples of religious retentionists who indicated their allegiance to free-will or "personal responsibility" perspectives, see House of Commons Debates (14 May 1976), 13538 (Alex Patterson, MP Progressive Conservative, Fraser Valley East, BC); (28 May 1976), 13955 (Jake Epp, MP - Progressive Conservative, Provencher, MB); (5 July 1976), 15024 (Benno Friesen, MP - Progressive Conservative, Surrey-White Rock, BC); see also LAC, MG32, Series B27 (Marcel Lambert fonds), Volume 81, File 14 File Title: "Capital Punishment 1976 file 2," Ernest Kennedy to Max Saltsman, June 25, 1976. For evidence that Patterson was religious, note that, according to Patterson's biographical data on the Parliament of Canada's Web site, he was a minister by vocation http://www.parl.gc.ca/information/about/people/key/bio.asp?query=1506\&s=M\&Language=E (accessed February 7, 2007). Along with the Whiteway quote above, the Friesen speech and Kennedy letter reveal that B.F. Skinner was a favourite target.
} 
$1956 .{ }^{55}$ The document took pains to disavow determinist theory. ${ }^{56}$ "Man is a responsible being," it declared. "The gospel teaches that people can choose between good and evil." Again, "[m]an is not a mere creature of heredity and environment and sin is not merely a disease." But statements of contrasting tone also appeared. The authors noted that "there are sociological and pathological situations in which the responsibility of the individual almost ceases and he becomes the instrument of mental, social and physical conditions." More strikingly,

as most serious offences are symptomatic of social or psychological aberrations, the treatment of the offender should be determined by a diagnostic investigation which should be an integral part of a treatment process commencing before trial and ending with the ultimate emancipation of the offender from his criminality.

We do not recommend that summary trial and punishment for acts of simple irresponsibility which have no pathological significance should be abandoned but we do most earnestly recommend that a correctional system dedicated to total treatment be evolved and that the nature and length of treatment in each case be determined by Treatment Authorities operating in Reception and Diagnostic Centres appropriately located throughout the country. ${ }^{57}$

The seeming incongruousness between the document's discussion of human

responsibility in general and its vision for the penal system makes it doubly clear that the affirmations of human agency primarily reflected loyalty to religious viewpoints. The proposals regarding public correctional policy, meanwhile, aligned with postwar

\footnotetext{
${ }^{55}$ Board of Evangelism and Social Service, the United Church of Canada, Alternatives to Capital Punishment: Full Text of the Report of the Committee on Alternatives to Capital Punishment to the Nineteenth General Council of the United Church of Canada, September 1960, Edmonton, Alberta (Toronto: Board of Evangelism and Social Service, the United Church of Canada, [1960]), 1. Copies of this document were mailed to parliamentarians - see LAC, MG32, Series B1 (Richard Albert Bell fonds), Volume 107, File 11 - File Title: "Capital Punishment 1960-61," William G. Berry to Members of the Senate and the House of Commons, December 5, 1960. 1960 , p. 6.

${ }^{56}$ On this point, see also Wm. G. Berry, letter to the editor, Toronto Daily Star, September 24,

${ }^{57}$ Board of Evangelism and Social Service, the United Church of Canada, Alternatives to Capital Punishment, 3-4. Italics in original.
} 
mentalities in many respects: in the two decades following World War II, the going view of crime and corrections made more use than ever of a medical framework..$^{58}$

Be that as it may, the document quickly faced a public attack — from the soundly abolitionist Toronto Daily Star, of all places. On September 22, 1960, an editorial pronounced it "a disturbing document" with a "basic philosophy" that "is quite at variance with Christian belief." In the editorialist's mind, the authors had mixed their criminal and medical metaphors badly, and he suspected that they had not intended the offending ideas as mere metaphor. In effect, he claimed, the discussion contravened "the belief that man is responsible to God for his conduct," and it promoted a mentality that would leave "the foundations of our moral code" in poorer shape than before. ${ }^{59}$

The Reverend William Berry, one of the document's creators, ${ }^{60}$ replied to the editorialist's complaint in a letter to the editor. Berry pointed out the pro-free-will statements found in the document, and he argued that such ideas remained compatible with the document's discussion of crime and corrections. To Berry, the point of drawing parallels between penal affairs and medical affairs was not to suggest that criminals had earned no blame en route to the state in which they found themselves. "We are all sinners," noted Berry, including "[p]eople in hospitals and mental institutions." Moreover, "[f]requently their sickness is due to their sin." But this did not mean that sin

\footnotetext{
${ }^{58}$ See John W. Ekstedt and Curt T. Griffiths, Corrections in Canada: Policy and Practice (Toronto: Butterworths, 1984), 49-53; see also Elise Rose Chenier, "Stranger in Our Midst: Male Sexual 'Deviance' in Postwar Ontario" (Ph.D. Thesis, Queen's University, 2001 - Ottawa: National Library of Canada, [2002]), 7-10, http://www.collectionscanada.ca/obj/s4/f2/dsk3/ftp05/NQ63412.pdf.

${ }^{59}$ Editorial, "The Sick and the Sinners," Toronto Daily Star, September 22, 1960, p. 6. Capital Punishment, 14.
} 
should get all the attention; instead, "[w]e recognize that sinful people may also be sick people." Did Berry mean to suggest that just as an individual's deliberate conduct could expose him to and result in contraction of a physical illness, from which he could not then escape exclusively by an act of willpower, so volition allowed an offender to set out on a criminal path initially, but not necessarily to reverse course? Berry's letter did not really clarify this issue; this too was not his main point. Instead, he wished to emphasize that non-offenders should work to end offenders' entanglement in crime just as heartily as they backed efforts to assuage citizens' medical problems, and that punitiveness should not infiltrate their efforts. "We recognize that sinful people may also be sick people, and that the whole resources of society are needed for the work of rehabilitation and indeed of redemption," wrote Berry. Indeed, "there is no area where both the Christian Church and society are more likely to be guilty of a pharisaic moralism which condemns sin without regard to the redemption of the sinner than in the area of corrections."61 In effect, Berry believed that contemplation of the penal system ought to draw as much attention to the responsibility of the non-criminal population, particularly Christians, as to that of lawbreakers. ${ }^{62}$ To him, therefore, the idea of human moral responsibility pointed not toward the execution of blameworthy murderers, but toward abolition and wholehearted expenditure of rehabilitative energy.

The UCC document and the subsequent exchange in the Star reflect some of the

\footnotetext{
${ }^{61}($ Rev.) Wm. G. Berry, letter to the editor, Toronto Daily Star, September 24, 1960, p. 6.

${ }^{62}$ The terms "responsibility" and "duty" appear recurrently in the UCC document's discussion of Christians and rehabilitative involvement with offenders - see Board of Evangelism and Social Service, the United Church of Canada, Alternatives to Capital Punishment, 1-3, 6-7; see also 8.
} 
key dynamics in Canadians' discussion of human responsibility during the death-penalty

debate. Insistence that humans qualified in principle as responsible actors often sprang from a religious outlook..$^{63}$ Many people, however, showed less inclination to envision human agency as a given within a human existence defined by transcendent realities. Indeed, the idea of calling murder an overwhelmingly volitional phenomenon left a number of them feeling dubious. But if such skepticism seemed to pare down the responsibility that an offender would have to acknowledge, it could sometimes reinforce the perceived moral responsibility of non-offenders. Whether theoretical or practical, explicit or implied, complete or qualified, responsibility remained a persistent component of Canadians' conception of the human being — or at least of their conception of themselves.

\section{Psychology, Psychiatry, and the Mysterious Human}

The Toronto Daily Star thought that the UCC's Alternatives to Capital Punishment displayed an excessively "deep faith in the curative powers of psychiatry for criminality." ${ }^{64}$ C.L. Thompson, E.L.H. Taylor, and others who shared their hostility toward psychiatric ideas might have been inclined to express rather more vigorous

\footnotetext{
${ }^{63}$ For another example of a highly religiously oriented abolitionist who affirmed human free will, see LAC, MG32, Series B27 (Marcel Lambert fonds), Volume 81, File 12 - File Title: "Capital Punishment 1975," Ross Rains to "Member of Parliament," undated (but an essay attached to this letter [Ross Rains, "A Christian's Plea for Abolishment: Moral Imperatives and the Death Penalty"] bears the date August 29, 1975).

${ }^{64}$ Editorial, "The Sick and the Sinners," Toronto Daily Star, September 22, 1960, p. 6.
} 
skepticism. ${ }^{65}$ Such examples serve as a reminder that psychiatry had certainly not become an object of reverence for the entire Canadian public. Nevertheless, it remains true that discussion of psychological ideas abounded in mainstream Canadian culture during the postwar years, and that in many Canadians' eyes, psychological theory possessed significant capacity to create a more accurate picture of the hows and whys of human feeling and conduct. For instance, non-academic writers of the day demonstrated a great affinity for vocabulary or concepts connected in some respect to well-known psychological teachings. Although behaviourist perspectives appeared at times within such discussions, the Freudian brand could also boast a major market share. ${ }^{66}$ It is unsurprising, then, that various participants in the death-penalty debate made general references (from a non-hostile standpoint) to the theoretical findings and applied endeavours of psychologists and psychiatrists. Occasionally debaters discussed notions associated with the actual content of psychological theory. Paradoxically, references to psychological knowledge could at times have the effect of allowing debaters to justify a present inability to comprehend the past actions of killers or precisely specify their future potential ${ }^{67}$ Such justifications proved useful to both abolitionists and retentionists.

Participants in the death-penalty debate did not use Freudian lingo frequently. However, Freudian and quasi-Freudian notions perhaps helped to foster the impression

\footnotetext{
${ }^{65}$ For other examples of suspicion toward psychiatry or psychology, see T.J.T. Williams, letter to the editor, Globe and Mail, April 21, 1958, p. 6; W. Humphrey, letter to the editor, Globe and Mail, April 28, 1958, p. 6; House of Commons Debates (31 January 1973), 835 (Ian Arrol, MP - Progressive Conservative, York East, ON).

${ }^{66}$ The preceding four sentences are based upon Owram, Born at the Right Time, 20, 25, 35-45.

${ }^{67}$ I may owe the inspiration for this point, around which this section of the chapter revolves, to a vaguely similar idea (in a very different context) in McKillop, Disciplined Intelligence, Chapter 4, "The Veils of Isis," including 101-102, 106.
} 
among Canadians that a world of unexpected mental and emotional phenomena dwelt "inside" the human individual - a world of abundant unrest (whether perceptible or in disguise), in which "forces" and "impulses" could surge mightily without warning. ${ }^{68}$ For instance, one MP made reference to "the concept of the id lurking in the murky labyrinth of the subconscious which is supposed to bubble to the surface and cause the perpetration of all sorts of heinous crimes." ${ }^{\text {69 }}$ Such impressions about the human makeup could occasionally fill a conceptual or rhetorical need. For instance, they could contribute to a possible answer to an important question in the capital-punishment controversy. How could it be that when the victories and defeats in the battle to suppress homicide were chalked up, the death penalty had no success to boast about that non-lethal penalties could not match? While speaking to Parliament, Lester Pearson offered some thoughts relevant to the problem. "[T]he human spirit," he declared,

is infinitely complex, a collection of constantly competing needs and wants and emotions which no law can perfectly control.

Fortunately, Mr. Speaker, most of mankind manages for most of the time to keep all these clashing forces that operate within a single personality in a kind of balance and under some control. But when an overpowering primal emotion breaks loose, no instinct, not even that of life or death, can oppose the tyranny of that irresistible force. Therefore a murder can occur. So for capital punishment to really be a deterrent, human nature would have to be as stable and cold as the law itself. And human nature, Mr. Speaker, is far from that. ${ }^{70}$

\footnotetext{
${ }^{68}$ See Owram, Born at the Right Time, 36-44. For references to such "forces," see the examples below. On the mental pictures, naturalized among Westerners, of the self's residing "inside," see Norbert Elias, The Civilizing Process: Sociogenetic and Psychogenetic Investigations, rev. ed., trans. Edmund Jephcott with some notes and corrections by author, ed. Eric Dunning, Johan Goudsblom, and Stephen Mennell (Oxford, UK: Blackwell Publishers, 2000), 478-481. On Westerners' "sense of ourselves as beings with inner depths," see Taylor, Sources of the Self, including X.

${ }^{69}$ House of Commons Debates (22 May 1973), 3987 (Walter Dinsdale, MP - Progressive Conservative, Brandon-Souris, MB).

${ }^{70}$ House of Commons Debates (16 November 1967), 4369; see also 4370 (Lester Pearson, MP Liberal, Algoma East, $O N$ ). The last four sentences of this statement by Pearson appear to be a paraphrase of a statement by Albert Camus - cf. Albert Camus, "Reflections on the Guillotine," trans. Justin O'Brien,
} 
Pearson's statement implicitly conveyed the sense that human psychology and action did not lend themselves to easy explanation or forecast. This notion became more explicit later in the same speech when he referred to "the most intricate and mysterious and precious of all mechanisms, the individual personality and the influence of heredity and environment which affect it."71 This impression of inscrutability also appeared on several other occasions in the debate. During the controversy over Steven Truscott's death sentence in 1959, an abolitionist letter to the Globe referred to individuals' engaging in crimes "by reason of what unknown psychotic or traumatic experience" and "by reason of similar unkenned compulsion." The following year, in the process of advocating that Adolph Eichmann not be punished through execution, Rabbi Abraham Feinberg of Toronto advised that having Eichmann still present in the world would permit "research into the eternal, universal, problem of human evil," with opportunity to "dig out and look at the cancerous seeds of the brute in man" and find "a tiny window into the tangled chaos of human conduct." ${ }^{.73}$ Similarly, while arguing against the death penalty for "even the most sadistic, brutal murderer," MP Donald Tolmie urged that society could "achieve more by preserving him so his abnormal behaviour can be studied by psychiatrists," a necessary strategy "if we are to delve into the dim recesses of irrational

in Albert Camus, The Plague, The Fall, Exile and the Kingdom and Selected Essays, introduction by David Bellos (New York, NY: Alfred A. Knopf, 2004), 621. This essay first became available to the public in 1957, with an English translation becoming available in 1960 or 1961.

${ }_{71}^{71}$ House of Commons Debates (16 November 1967), 4371 (Lester Pearson).

${ }_{72}^{72}$ Sydney M. Harris, letter to the editor, Globe and Mail, October 6, 1959, p. 6.

${ }^{73}$ Abraham L. Feinberg, "Let Adolph Eichmann Live!" Globe and Mail, June 21, 1960 , p. 6. 
behaviour" and "learn how these sick minds work." ${ }^{\text {" }}$ Another abolitionist suggested that because the human individual was unfathomable, the moral realities obtaining in a given murder case became partly unfathomable as well, while retributive criteria required verification of these realities prior to the execution of the offender. "[T]he mystery of human nature deepens," he advised. Indeed, "[w]hen a person kills he responds to a varying number of imponderables, the outward behavior being a symptom of this conflict. A man being sentenced to death[,] the crown presumes full knowledge of these imponderables. Is the law capable of being God?"75 In another MP's speech, related images of impenetrability appeared again in conjunction with the deterrence issue, although in this case the MP drew a clear distinction between the psychology of killers and of others. "A normal person" might act in obedience to a deterrent, but killers "are abnormal people driven by who-knows-what compulsive forces. Certainly, they are driven sometimes by strong emotional forces, by forces accompanying insanity, even though their particular state of mind at the time may not be legally so defined."76 In sum, believing that the human possessed great capacity to display the unexpected and the unfathomable probably helped to prevent a sense of discomfort at being unable to describe precisely why murderers did the deed. And if it could be difficult to explain (in a manner that retentionists would find convincing) how abolition would create specific advantages for anti-murder efforts, why analysis of moral guilt showed abolition to be the

\footnotetext{
${ }^{74}$ House of Commons Debates (5 April 1966), 3875 (Donald Ross Tolmie, MP - Liberal, Welland, ON). Here Tolmie emphasized the "abnormal," but in the same speech he referred to the "primitive urges which are scarcely concealed beneath the surface of us all" - see page 3876.

${ }_{75}^{71}$ an D. Coward, letter to the editor, Toronto Daily Star, November 24, 1972, p. 7. Bay, ON).

${ }^{76}$ House of Commons Debates (29 January 1973), 739 (B. Keith Penner, MP - Liberal, Thunder
} 
wisest option, or precisely why the abolitionist description of deterrence was correct, then perhaps the image of the enigmatic human helped matters out a little.

Various participants in the debate portrayed psychologists and psychiatrists rather favourably, pointing admiringly to the theoretical clarification they provided and to their potential to steer the penal system through to a place of genuine rehabilitative achievement. Rebutting the notion that "respect for the law" would dissipate in the absence of the death penalty, Ed Broadbent declared that " $[t] h e$ modern teachings of psychologists, either behavioural or Freudian, completely shatter that view. It has been shown that violence does nothing but create more violence." $" 77$ To MP Gilles Marceau, a similar source seemed to provide backing for the abolitionist side in the dispute concerning deterrence. Believing that people made decisions after thinking ahead and selecting the most advantageous option proved to be the retentionists' point of incorrect departure, argued Marceau, for "modern psychology and sociology" suggested "that human behaviour, far from being calculated and conscious, obeys to a large extent to [sic] habits and inspiration of the moment." ${ }^{\text {78 }}$ At times, then, the rhetorically invoked psychologist seemed to be a figure who served to reassure debaters that the answer to tricky issues already lay fully within reach.

In a number of cases, however, debaters' positive portrayal of psychiatrists and psychologists hinged less upon the good results that these mind-smiths had already

\footnotetext{
Whitby, ON).

${ }^{77}$ House of Commons Debates (24 July 1973), 5949 (Edward Broadbent, MP - NDP, OshawaQC).

${ }_{78}$ House of Commons Debates (28 May 1976), 13948 (Gilles Marceau, MP - Liberal, Lapointe,
${ }^{2}$.
} 
delivered than upon what they would perhaps be able to deliver in coming times. This was particularly the case when discussion turned to rehabilitation. With the rehabilitative endeavours of the Canadian penal system currently appearing distinctly sub-optimal to many debate participants, ${ }^{79}$ abolitionists maintained expectations for better days ahead. Psychiatrists, they believed, would contribute much to validating this hope in the end. One abolitionist MP spoke of the "new penal institutions, new forms of rehabilitation and new universities to train the psychiatrists and psychologists that are needed in such vast numbers if rehabilitation is to have any effect." He believed these new resources would emerge more quickly following abolition, when the country would realize their necessity, rather than merely hoping that the death penalty itself would satisfactorily do the job of crime suppression. ${ }^{80}$ Noting the orderly and non-antagonistic approach to life that incarcerated killers typically adopted, another abolitionist declared that

[i]f we were smart we would start to study them scientifically and we would use all the facilities of sociology, psychology and psychiatry to do so. We would work with these people, and perhaps in a generation we would know how to substantially reduce crimes of violence. ${ }^{81}$

Humans might still pose too challenging a puzzle for authorities to lay out consistently successful rehabilitative and crime-averting initiatives. But abolitionists believed that this did not need to paralyze plans for abolition, partly because of the psychiatric and psychological resources that would, they hoped, bring the system onto a new path of

\footnotetext{
${ }^{79}$ See, for instance, House of Commons Debates (28 March 1966), 3310 (Steven Otto, MP Liberal, York East, ON); (4 April 1966), 3822-3823 (J.-P. Goyer, MP - Liberal, Dollard, QC).

${ }^{80}$ House of Commons Debates (28 March 1966), 3314 (Bryce Mackasey, MP - Liberal, Verdun, QC). See also House of Commons Debates (4 April 1966), 3838 (Jean-Eudes Dube, MP - Liberal, Restigouche-Madawaska, NB).

${ }^{81}$ House of Commons Debates (9 November 1967), 4106 (John R. Matheson, MP - Liberal, Leeds, ON).
} 
success at some point ahead. ${ }^{82}$

Some retentionist MPs employed similar notions about psychiatrists, psychologists, and future hopes, but pressed these claims into retentionist service. To hear certain retentionists tell it, an absence of plentiful input from these professionals would markedly lower the chances for offenders' true character and potential to become fully clear to penal authorities, or for rehabilitative competence to develop within the correctional system. ${ }^{83}$ Retentionists thought that the quandaries and dead-ends still confronting authorities throughout the rehabilitative quest made it wise to let more water flow under the bridge before making the country a death-penalty-free zone. ${ }^{84}$ But time, a few of them suggested, might be able to alter the picture: a ramped-up level of rehabilitative success would signal that the clock had struck abolition hour. ${ }^{85}$ One MP made the case with reference to unspecified medical input rather than psychiatric endeavours in particular. In his estimation, people of the mid-twenty-first century would feel "surprise" upon learning of Canadians of the 1960s who "had not sufficiently advanced to the point where we could by medical science and sociological approaches do

\footnotetext{
${ }^{82}$ For a similar characterization of the outlook of proponents of criminology early in the century, though not in a Canadian or abolitionist context, see Garland, Punishment and Welfare, 107.

${ }^{83}$ See House of Commons Debates (9 November 1967), 4115-4116 (George Hees, MP Progressive Conservative, Northumberland, ON); see also House of Commons Debates (5 April 1966), 3888-3890 (P.B. Rynard, MP - Progressive Conservative, Simcoe East, ON); (23 November 1967), 46404641 (P.B. Rynard, MP).

${ }^{84}$ See House of Commons Debates (24 March, 1966), 3127 (Auguste Choquette, MP - Liberal, Lotbinière, QC); (28 March 1966), 3273 (Maurice Allard, MP - Independent Progressive Conservative, Sherbrooke, QC); (16 November 1967), 4344 (Gordon Churchill, MP - Progressive Conservative, Winnipeg South Centre, MB); (23 November 1967), 4638-4639 (Joseph-Alfred Mongrain, MP Independent, Trois-Rivières, QC).

${ }^{85}$ See House of Commons Debates (16 November 1967), 4344 (Gordon Churchill, MP Progressive Conservative, Winnipeg South Centre, MB); (23 November 1967), 4638 (Joseph-Alfred Mongrain, MP - Independent, Trois-Rivières, QC).
} 
something more realistic toward criminals than we are now able to do. However, ... we are not living 100 years from now; we are living in 1966." Certainly, he assured his fellows, "I will welcome the day when the penalty of death can be abolished. That day will come when medical science has delved into the human mind, and can straighten out the warped, vicious and antisocial behaviour of those who are a menace to society." But "[t]hat day has not yet come." ${ }^{.86}$ Another MP suggested that dealing optimally with offenders would, among other things, involve obtaining "[a]n army of experts on the rehabilitation of criminals," including "competent psychologists." Too few of these resources existed as of yet in the penal system. "When we are ready," he suggested, "we will be in a better position to consider abolition of capital punishment, because retention must not be an everlasting and absolute decision." ${ }^{87}$ Claiming to envision an improved rehabilitative future - a vision linked to potential psychiatric findings - allowed retentionists to draw attention to current rehabilitative uncertainties and to use these difficulties as legitimation for retention without feeling that they appeared unconstructive, willfully ignorant, or eager to execute. Indeed, sometimes explanatory frameworks and still-inexplicable phenomena could form a rather satisfying combination.

\section{Psychology, Animality, and the Impulsive Human}

Psychological investigation of and findings concerning the human being did not serve

\footnotetext{
${ }^{86}$ House of Commons Debates (4 April 1966), 3844 (G.H. Aiken, MP - Progressive Conservative, Parry Sound-Muskoka, ON).

${ }^{87}$ House of Commons Debates (5 April 1966), 3896-3897 (Jean-Paul Matte, MP - Liberal, Champlain, QC).
} 
only as a source of discovery that lent paradoxical legitimacy to current deficits in knowledge. Among other rhetorical functions, Freudian-flavoured impressions about the human could also draw attention to the importance of moral sobriety and commitment. One letter writer believed that quasi-Freudian concepts would help people to perceive and acknowledge severe blemishes among the human proclivities in which they themselves shared. If citizens found themselves inclined to evaluate the death penalty favourably, that revealed the operation of reprehensible appetites within them - such appetites as

[o]ur latent hatreds, our suppressed anger, our wish to have revenge and even those instincts we hardly even dare admit in others, such as the excitement of knowing that a man is to be done to death at a certain time, a certain place and in a certain manner, even the sex excitement of an execution.

These "uglier motives" kept retentionist opinion robust; by contrast, a professed belief in justice, deterrence, or religious teachings acted largely as a beautifying device. "Let us ... admit to ourselves," the writer urged, "that we all love a good hanging; and to probe a little deeper, many of us enjoy killing or enjoy watching it being done." This unpleasant reality demanded serious attention, for it related to one of the most distinctive perils of the postwar world:

Once we have faced this fact we can start to deal with it intelligently, for in the last analysis every street in the world is Death Row, and the stay of execution that prevents Mr. Ellis doing his awful work at the rocket launching pads can come only from our deepest self-understanding. ${ }^{88}$

If in one sense the letter seemed to call for the acknowledgment of moral guilt

\footnotetext{
${ }^{88}$ D.R. Morgan, letter to the editor, Globe and Mail, February 23, 1960, p. 6. Along somewhat similar lines, see Jeff Barnard, letter to the editor, Toronto Daily Star, July 20, 1971, p. 7. For a discussion containing different but related themes, see LAC, MG32, Series B35 (Walter Gilbert Dinsdale fonds), Volume 79, File 2 - File Title: "Capital Punishment. General 1973," J. Harwood-Jones to "All Members of Parliament" and "All Senators," "Capital Punishment - An Issue for Everyman," undated.
} 
associated with the "uglier motives" from which retentionist sentiment sprang, the matter remained partially unclear, for the writer did not actually specify how people should "deal with" these "ugly" inclinations. Was the letter recommending psychotherapy for all citizens animated by said ugly inspiration? It seems more likely that the writer envisioned a solution largely involving moral response by citizens - a response, that is, of deliberate decision to minimize the influence of such inclinations over their actions. Another abolitionist statement issued this call somewhat more directly:

[T] he desire for vengeance has deep, unconscious roots and is roused when we feel strong indignation and revulsion. That we are all subject to these occasional vindictive impulses is unfortunately true, but such impulses should not be legally sanctioned by society as is the case in hanging. The gallows is more than a death machine, it is a symbol of the primitive savagery, mediaeval fanaticism and modern totalitarianism that man must reject if he is to survive the present crisis. ${ }^{89}$

In effect, some of the "impulses" of the unfathomable, quasi-Freudian self required largely the same response as did the "temptation" of more religiously oriented analyses of human experience - a committed choice to spurn the illicit attraction.

Abolitionists could portray the bridling of unwholesome impulses as a small step toward reducing the danger of world disaster, but they could also point to benefits of a

\footnotetext{
${ }^{89}$ LAC, MG32, Series B35 (Walter Gilbert Dinsdale fonds), Volume 78, File 12 - File Title: "Capital Punishment. General. n.d.; 1953-1967," "Capital Punishment," January 29, 1960. It is not clear who authored this three-page document. However, what appears to be a revised version of the same document appeared again in MPs' mailboxes five years later - see LAC, MG32, Series C31 (Heath Nelson Macquarrie fonds), Volume 42, File 31 - File Title: "Capital Punishment. 1965," "Capital Punishment," brief from the Social Action Committee of the Unitarian Congregation of South Peel, Port Credit, Ontario, attached to Arnold Thaw, Minister, and Arthur Harris, Chairman, Social Action Committee, Unitarian Congregation of South Peel to All Members of Parliament, April 27, 1965. The first two sentences of the quoted passage above also appear, in slightly modified form, in LAC, MG32, Series B35 (Walter Gilbert Dinsdale fonds), Volume 79, File 5 - File Title: "Capital Punishment. General, Feb.-July 1976," "Statement on Capital Punishment from Canadian Association of Elizabeth Fry Societies," attached to Margaret McKee, President, Canadian Association of Elizabeth Fry Societies to All Members of Parliament, February 20, 1976. Along similar lines, see, in the same file, Catherine J. M. Brockway, Psychologist, and Rev. Robert W. Brockway to Walter Dinsdale, February 24, 1976.
} 
more optimistic flavour. MP Donald Tolmie believed that such restraint could claim a key role in the heritage and prospect of progress. "As society develops and the sanctity of life becomes more ingrained into our philosophy," he effused,

as we struggle to combat our primitive urges which are scarcely concealed beneath the surface of us all, gradually through quiet evolution we have discarded old ideas of retribution and punishment.... Is not the abolition of capital punishment the natural culmination of centuries of man's effort to achieve justice based on reason?

Tolmie also thought that "revenge ... is understandable but ... is not compatible with the degree of civilization we have attained," and that terminating a killer via execution "brutalizes society and lowers it toward his own depraved and savage level." the human being enjoyed little respite from "scarcely concealed" "urges," retained some affinity for depravity, could look to numerous precedents for continued human improvement, and could set another such precedent through "struggle." For Tolmie's human, life retained a goodly share of moral drama.

In keeping "the standard of civilization we have attained" in mind while mulling penal options, Tolmie was thinking in the same vein as many of his fellow citizens. Canadians frequently turned to such terms as "civilized" and "barbaric" as their adjectives of choice when discussing the death penalty and related issues. ${ }^{91}$ However, in

\footnotetext{
${ }^{90}$ House of Commons Debates (5 April 1966), 3876, 3875 (Donald Ross Tolmie, MP - Liberal, Welland, $O N)$.

${ }^{91}$ Letters to the editor and parliamentarians' speeches are full of these and related terms. As discussed in the introductory chapter, Carolyn Strange has shown how centrally the notion of being civilized undergirded Canadians' approach to evaluating capital punishment at mid-century - see Strange, "Undercurrents." For a discussion revealing the substantial degree to which citizens in some areas of the United States have drawn upon the ideal of civilized life when considering the death penalty, see Judith Randle, "The Cultural Lives of Capital Punishment in the United States," in The Cultural Lives of Capital Punishment: Comparative Perspectives, ed. Austin Sarat and Christian Boulanger (Stanford, CA: Stanford University Press, 2005), 94-95, 97, 100-104.
} 
maintaining a highly positive attitude toward practices and viewpoints that appeared “civilized," Canadians were not merely rejecting relatively ruder, rougher, or rawer approaches to life. Rather, at least some people believed that the capital-punishment issue provided a reminder of starker and darker realities and possibilities concerning human character and conduct - possibilities that contrasted more sharply with such ideals as being civilized. For example, some citizens shared Tolmie's belief that capital punishment provided an avenue by which people could continue to partake in "savagery." The death-penalty controversy led certain other Canadians to picture the human being not merely as a "savage," but as an animal.

Though far from pervasive, verbal images of animality appeared on numerous occasions within arguments levied for and against the death penalty. Time and again debaters compared or contrasted some aspect of the person, makeup, dispositions, or activity of killers or other people with those of animals. Many of these references served largely as colourful metaphor; occasionally the comparisons seemed to became more literal. Debaters' animal-themed statements did not necessarily reveal their true opinions about non-human animals, ${ }^{93}$ for they used this rhetoric primarily to make points concerning human life. Taken together, however, their various assertions and allusions reveal some of Canadians' assumptions about the relationship between humanness and

\footnotetext{
${ }^{92}$ See House of Commons Debates (16 May 1973), 3847 (see also 3846) (David Lewis, MP NDP, York South, ON); see also House of Commons Debates (16 February 1962), 967 (Harold Winch, MP - NDP, Vancouver East, BC); Ruth Worth, "A Savage Releases the Savage in Others," Globe and Mail, November 21, 1964, p. 6; editorial, "At Last an Open Vote on Capital Punishment," Globe and Mail, December 4, 1964, p. 6.

${ }^{93}$ I owe my thinking on this matter to points raised verbally by Dr. Dominique Marshall of Carleton University following a paper presentation.
} 
animal existence more generally, and also show how compelling many citizens found this issue to be. In varying ways, Canadians sensed that noteworthy areas of overlap, or of potential overlap, existed between the human makeup and certain characteristics of other members of the animal kingdom. But they placed great significance upon humanity's possession of attributes and forms of experience in which no other animal held the capacity to participate. They also sensed a moral urgency to cultivate these special distinctives of humanness and to fend off any tendency for other aspects of animal character to acquire greater influence in their behaviour and outlook. ${ }^{94}$ This set of assumptions opened avenues for both abolitionist and retentionist argument.

Like the quasi-Freudian conception of the individual, the discussion of animality could suggest the importance of ensuring that the individual's unwholesome impulses would receive little opportunity to blossom. In some retentionists' estimation, people risked losing out badly if they tried to carve out a life for themselves that contained few strong impediments to confront them when they became inclined to make detrimental choices. References to animality offered one means to convey this point, and to portray the death penalty and mentalities associated with it as the type of impediments that people should value. "You may be sure that should it be known tomorrow that capital punishment has been abolished there would be a considerable increase of criminals who would give free course to their feelings of hatred and jealousy," declared one MP. "We

\footnotetext{
${ }^{94}$ Certain statements (concerning different historical settings than the one pertinent to this thesis) in a book by Merle Curti helped in a very general way to stimulate my thinking concerning the idea of animality in people's perspectives on humanness - see Merle Curti, Human Nature in American Thought: A History (Madison, WI: University of Wisconsin Press, 1980), 4, 6, 16, 24, 32, 38, 46, 48, 60, 130-131, 408, especially $4,24$.
} 
are, after all, not like other animals. We are reasonable animals. Always a night lamp of conscience shines within us restraining our desires and instincts. In this case, once capital punishment has been abolished, this lamp will not shine again." ${ }^{95}$ Other retentionists used phrases that could spark mental images either of "primitive" humanity or of animal life. "[A] greater power than ourself [sic] has so ordained things in this world, that we must and shall reap as we sow," declared one critic of abolitionism. Awareness of this reality, he implied, meshed well with acceptance of capital punishment. "Without this philosophy of sowing and reaping, I fear we would long ago have gone back to the jungle."96 Another retentionist noted the presence of lethal penalties in "[t]he earliest recorded laws of man." "[1]f there had not been some provision in those early times for controlling the base impulses of man," he suggested, "these impulses would have been paramount and would have won over the instincts that took man out of the caves and the trees."97 The thought that Canadians might start to take lessons from the non"reasonable" animals or might catch an appealing whiff of humanity's Stone Age ways undoubtedly seemed melodramatic to some listeners. But it could also reassure certain retentionists that the persistent human propensity to engage in bouts of waywardness only confirmed how valuable a corrective coercive sanctions could provide. And with this reassurance, they could also maintain that capital punishment ought not to be ruled out of court glibly in the present.

\footnotetext{
${ }^{95}$ House of Commons Debates (30 May 1958), 716 (Maurice Allard, MP - Progressive Conservative, Sherbrooke, QC).

${ }^{96}$ T.J. T-Williams, letter to the editor, Globe and Mail, January 28, 1960, p. 6.

${ }^{97}$ House of Commons Debates (24 July 1973), 5925-5926 (Duncan Beattie, MP - Progressive Conservative, Hamilton Mountain, ON).
} 
There is little reason to think that abolitionists found such suggestions persuasive. In fact, metaphor involving animality could help to promote skepticism about the deterrence that was purportedly generated where the death penalty reared its head. An important 1972 research report gave parliamentarians apparent statistical cause for such skepticism. As packed with numbers as the study was, it made space for a little nonquantitative persuasion as well. A sentence from Boris Pasternak's Doctor Zhivago appeared alone on one page within the front matter of the report: "If the beast who sleeps in man could be held down by threats - any kind of threat, whether of jail or of retribution after death - then the highest emblem of humanity would be the lion tamer in the circus with his whip, not the Prophet who sacrificed himself." ${ }^{" 98}$ As we will see in the following chapter, this report influenced MPs' discussion substantially. Three of them also liked the Pasternak quotation enough to repeat it themselves in the House of Commons. The declaration threw a two-pronged barb at a deterrence-focused mentality. Not only would deterrent efforts be dogged by perennial failure; they also seemed to amount to a morally second-rate strategy, a strategy that departed from what "the highest emblem of humanity" might inspire. ${ }^{99}$

However, if Pasternak's words denied that deterrent hostility would faze "the beast," they simultaneously affirmed something with which many retentionists agreed that people's desire or conduct could indeed become disturbingly comparable to that of

\footnotetext{
${ }^{98}$ Quoted in Fattah, Study of the Deterrent Effect, vii.

${ }^{99}$ See House of Commons Debates (14 May 1973), 3718 (Heath Macquarrie, MP - Progressive Conservative, Hillsborough, PEI); (22 May 1973), 3963 (Cyril Symes, MP - NDP, Sault Ste. Marie, ON); (29 May 1973), 4229 (James McGrath, MP - Progressive Conservative, St. John's East, NF).
} 
volatile animals. Various abolitionists accepted this notion as well. Abolitionists typically spent less energy than retentionists in pointing out parallels between animals and murderers. But some of them drew attention to the danger that non-criminal citizens might begin to dabble in animal ways, not by engaging in any illegal activity, but by harbouring reprehensible attitudes that facilitated approval of such criminal-justice practices as the death penalty. The death penalty "is conceived to satisfy not justice but our own basic, animal, inhuman instincts," warned one letter writer. ${ }^{100}$ Certain abolitionists suggested that vengeance bore the strong scent of the animal realm, a notion that they used to throw extra weight into their attack upon retributive execution. Canadians used the death penalty "for no nobler purpose than the most bestial motive known to man - revenge." "What we are doing," echoed a teenage Globe correspondent, “... is simply satisfying the animal urge for revenge." 102 The death penalty "appeals to the lower animal instincts of revenge and retribution," claimed an MP. ${ }^{103}$ Abolitionists' use of the rhetoric of animality thus followed a familiar pattern: a number of them, while believing that people's affinity for what was beast-like did constitute a genuine problem, emphasized the presence of this problem not among offenders, but among law-abiding Canadians.

${ }^{100}$ Aaron Carbell, letter to the editor, Globe and Mail, February 25, 1960, p. 6.

${ }^{101}$ Angus McDowell Blair, letter to the editor, Toronto Daily Star, April 1, 1966, p. 6.

${ }^{102}$ Michael Mouritsen, letter to the editor, Globe and Mail, April 9, 1966, p. 6.

${ }^{103}$ House of Commons Debates (22 May 1973), 3982 (Derek Blackburn, MP - NDP, Brant, ON). For another example, see LAC, MG32, Series B35 (Walter Gilbert Dinsdale fonds), Volume 79, File 5 File Title: "Capital Punishment. General, Feb.-July 1976," text from "a letter sent to 3 Ontario daily newspapers" by Rev. W. Clarke MacDonald, Chairman, and Rev. R.J. Scott, Secretary, Task Force for the Abolition of Capital Punishment of the Canadian Council of Churches, in attachment to (Rev.) Edward R C Blezard to Walter Dinsdale, March 5, 1976. 
Although these abolitionists believed that in certain respects and at certain times humans merited rhetorical comparison with animals, such comparisons possessed rhetorical power partly because of the fact that, according to abolitionists' (and other Canadians') predominant habits of thought, a categorical gap existed between humans and "animals." To put it another way, such abolitionists tended to believe that the points at which human character converged with that of other animals - or perhaps instead the traits that humans distinctively possessed when clad in their own metaphorical animal hide - formed a sort of second-rate aspect of human life, one which could potentially conflict with the attributes that qualified as more purely or ideally human. Accordingly, to describe vengeance or execution with animal-themed vocabulary was to show implicitly why society ought to regard these forms of punitiveness as ethically dubious: because such punitiveness seemed ultimately incompatible with one of the central categories - humanness - by which people defined their own identity. ${ }^{104}$ A few abolitionist comments provide hints of this perhaps not fully conscious pattern of thought. As we have seen, abolitionists could speak of "animal instincts" when alluding to people's attitudes. ${ }^{105}$ At the same time, another abolitionist asserted that "[t]he lust for blood is animal instinct — not human instinct." ${ }^{106}$ Perhaps most revealing is a statement already quoted above, in which an abolitionist linked the death penalty with "our own

\footnotetext{
${ }^{104} \mathrm{My}$ thinking here and in following paragraphs about the connection between identity and ethics was probably sparked to a significant extent, though in a rather general way, by Taylor, Sources of the Self, and Alasdair MacIntyre, After Virtue: A Study in Moral Theory, $2^{\text {nd }}$ ed. (1984 [ $1^{\text {st }}$ ed 1981]; repr., Notre Dame, Indiana: University of Notre Dame Press, 2003), perhaps especially 216-225. My portrayal of that connection, however, may not necessarily fit with the nuances of the points at which the above authors are driving.

${ }^{105}$ House of Commons Debates (22 May 1973), 3982 (Derek Blackburn, MP - NDP, Brant, ON).
${ }^{106}$ John S. Lynn, letter to the editor, Globe and Mail, February 3, 1965, p. 6.
} 
basic, animal, inhuman instincts."107 The contrast between these comments, which nonetheless all seem to have made broadly the same point, suggests an ambivalence in these abolitionists' minds about the relationship between the animalesque and the uniquely human within the human makeup - an ambivalence which itself fueled their ethical outlook. ${ }^{108}$ When they took a metaphorical look into the mirror, such abolitionists perceived a few animal features, saw and imagined certain more intrinsic human contours, and remained convinced that the latter needed to crowd out the former. Abolitionists drew upon and reinforced this pattern of assumptions concerning identity and ethics when they made statements that incorporated both the concept of animality and the dimension of historical time. With sequential time in the picture, direct or implicit narrative emerged, and narrative helped to solidify both identity and ethical confidence. ${ }^{109}$ The storyline that abolitionists perceived might be put metaphorically as follows: though human character and experience had reflected the harshness of an often bleak climate, the sun had continued to grow brighter than it had been in eras now departed. To these abolitionists, this striking yet incomplete improvement of an initially bleak picture constituted the central evidence on which to focus when summarizing humanity's experience and status, and it simultaneously served as a norm from which to

\footnotetext{
${ }^{107}$ Aaron Carbell, letter to the editor, Globe and Mail, February 25, 1960, p. 6. Emphasis added.

${ }^{108}$ For an abolitionist speech on capital punishment that discusses animality and humanness extensively and advances a viewpoint differing from what I am describing among other abolitionists' comments, but which constitutes a particularly striking example of the habit of thinking of human beings as both animals and other-than-animals, see House of Commons Debates (16 November 1967), 4365-4367 (Steven Otto, MP - Liberal, York East, ON); see also (28 March 1966), 3309-3310 (Steven Otto).

${ }^{109}$ Again, my thinking here and in following paragraphs about the connection between identity, ethics, and narrative was sparked to a significant degree by MacIntyre, After Virtue, especially 216-225, although my representation of this phenomenon may bear only a vague similarity to his.
} 
obtain guidance when considering what possibilities society currently ought to pursue or avoid. "It is regrettable that, despite his transformation from the caveman in the stone age to the sophisticated creature in this nuclear age, man has not yet risen from some of his animalistic inclinations," declared one citizen who was dismayed that capital punishment still occupied an active place in Canadian criminal justice. ${ }^{110}$ "The human race," pleaded another abolitionist, "has waged a long, hard and bloody battle to arrive at its present intellectual and spiritual level. Don't take us back, even one step, into the brutal animalistic past." She added, "We must find better ways to deal with people and the problems of this life." 11

As this citizen's words so nicely illustrate, abolitionists perceived and advocated improvement on both the moral plane and the instrumental front. In their eyes, ideals did and should grow more idealistic, becoming less "brutal," more "spiritual," and so forth. At the same time, they believed that people had grown increasingly skillful — and ought to become still more so - in outwitting challenges that would have formerly barred them from laying their hands on a desired outcome. Abolitionists' interest in this instrumental element of progress stands out particularly clearly in a speech by MP John Matheson. "In the past," he asserted,

society tried to correct many of its ills by killing off certain of its members. This is the action of the animal kingdom, the natural reaction to a threat. It is a stage in evolution which we see, hopefully, drawing to a close. In the stage of evolution we are entering we attack root causes ... not the victims of social ills.

\footnotetext{
${ }^{110}$ Eddie Rodriguez, letter to the editor, Toronto Daily Star, December 15, 1962, p. 6 (p. 99 in digital archive).

${ }^{111}$ Kathleen Crapper, letter to the editor, Toronto Daily Star, November 6, 1972, p. 7.
} 
Yet moral viewpoints and claims also pervaded his speech. ${ }^{112}$ Whether emphasizing moral maturation, instrumental development, or, most likely, a mix of both, abolitionists could use the terminology of animality to suggest in striking images that people had once explored harsh modes of life, that locating preferable zones of experience had formed a definitive element of human existence, and that to persist in this quest was incumbent upon those committed to true humanness.

These various facets of the overall pattern of thought came together most vividly when MP Ed Nelson spoke to the House of Commons. "What is it," he asked, that distinguishes mankind from the rest of the animals? Not necessarily the ability to reason, because some animals have shown that ability in varying amounts. But the one thing that man can do that other animals cannot do is to store experience.

...We must believe that man, through his ability to store experience and to learn from the past, is rising in the scale of human evolution. Despite this ability to store experience, it seems to us that the beast still lurks just below the sophisticated veneer of modern man. This is hardly surprising since man has been on this earth for a relatively short period of time in comparison with the entire scale of life, the continuum of life on this earth. ${ }^{113}$

If reflecting upon the aeons that had elapsed since Earth first became home to living things revealed "what a relative newcomer mankind is to the earth which he dominates," then reflecting upon present affairs clearly revealed some of the severe deficiencies that the human being still exhibited. "[T]he rapid advances in technology in the past few decades," Nelson observed, have by far outpaced the growth in man's social awareness and social

\footnotetext{
${ }^{112}$ House of Commons Debates (4 April 1966), 3801-3804 (John R. Matheson, MP - Liberal, Leeds, ON). The quote is from p. 3801.

${ }^{113}$ House of Commons Debates (31 January 1973), 848 (Ed Nelson, MP - NDP, BurnabySeymour, BC).
} 
consciousness; we can fly to the moon but we cannot deal with our social misfits. It is for this reason that we are still able to employ, despite the sophistication of our technology and the growth of our experience, such bestial methods in the wars, terrorist activities and homicidal acts which take place every day all over the world. ${ }^{114}$

But Canadians could claim no real excuse not to seek to shape up now. "Mr. Speaker, we are not beasts, but men and women," Nelson urged. "We are not savages, but civilized human beings. What we need is not a revival of the old ways of killing people, or discovery of new ways of killing people; what we need is an end to killing." Indeed,

[w] hat we need is the vision to look into the future for a method of separating those members of society who are not capable of functioning within our society, without succumbing to the forces of anger and animality that lie so near the surface of our civilized veneer.

... It may take time, but meanwhile we can find comfort and solace in the belief that we will, with a deep conviction in the worth of man, raise him yet another step on the evolutionary ladder to the heights at which he can say with conviction: It is wrong to use society's laws as a licence to kill. ${ }^{115}$

For Nelson, then, the idea of animality served as one of the key elements linking together the triangle of identity, narrative, and ethics that would facilitate sound judgment on the death-penalty issue. Human beings, he believed, could perceive much of their own nature and significance by surveying historical time, or at least the small portion of it pertaining to the human species, from a panoramic vantage point. The narrative discernible within that expanse of time explained why twentieth-century people could continue to gravitate toward troubling types of animal ways, but also why humans and

\footnotetext{
${ }^{114}$ House of Commons Debates (20 February 1973), 1484 (see also 1483) (Ed Nelson, MP - NDP, Burnaby-Seymour, BC). Nelson had had to stop part-way through his speech on January 31 due to the House of Commons schedule; on February 20 he summarized what he had said on January 31 and then delivered the rest of the speech.

${ }^{115}$ Ibid.
} 
animals stood on opposite sides of a hardening categorical boundary. Conversely, one of the central factors found only on the human side of that boundary - the "ability to store experience and to learn from the past ${ }^{\$ 116}$ — provided a major explanation for the progress that constituted such a key part of the human narrative. But this "ability to store experience," which was closely related to ingenuity in instrumental action, did not sum up the entire cleavage between animal ways and human traits. Nelson's words also suggested that the generic animal would plunge into violence with an enthusiasm incompatible with purely human character. Nelson spoke, for example, of "anger and animality" in the same breath, described various forms of present-day killing as "bestial," and announced that "we are not beasts, but men and women." With this latter statement, the pivotal role that identity played within his ethical perspective became obvious. And two primary elements of that identity — the two facets of the human's non-animality to which the speech had drawn attention - corresponded to the instrumental and moral facets, respectively, of the ever-deepening human vitality that Nelson believed could belong to Canadians if they would expend as much energy as they should upon its cultivation. Canadians would display one aspect of that vitality when they created "workable alternatives to" the death penalty and devised some non-lethal "method" for putting a chill on homicidal activity, thus proving their instrumental prowess. But Nelson used the climax of his speech to advocate a second form of progress that fell squarely within the category of moral change. If the death penalty could still find many

\footnotetext{
${ }^{116}$ House of Commons Debates (31 January 1973), 848 (Ed Nelson, MP - NDP, BurnabySeymour, BC).
} 
proponents in the Canadian body politic, mounting "the evolutionary ladder" a little

further would prepare the citizenry not just to abolish death sentencing, but to judge capital punishment "wrong," with this judgment born of "conviction."117 If, as some abolitionists saw it, neither criminals nor law-abiding Canadians could afford to forget about the animalesque, impulsive human that might show up at times in the mirror, they could turn to the human storyline to reassure themselves that this animalesque facet of their character held less significance than the most essential human traits defining their potential, and to inspire themselves to bring these latter traits always closer to the fore.

\footnotetext{
${ }^{117}$ House of Commons Debates (20 February 1973), 1484 (see also 1483) (Ed Nelson, MP - NDP, Burnaby-Seymour, BC). Note also the following statements that convey one or more of the types of ideas that Nelson expresses. A 1965 abolitionist speech by René Lévesque, who at the time could claim membership in the cabinet of Quebec Liberal premier Jean Lesage, referred multiple times to "the jungle," "animal[s]," or "beast[s]," and included the following statement: "Let the legislators show the way to a society in need of progress. Thus they could assist by eliminating this [death] penalty - by taking this final step. This is one of the most important which must still be taken before the monkey, which one day became a man, may finally come out of his jungle, stand up on his hind legs like a man and not fall back on his four paws and revert to his primitive state, but become truly more civilized" - LAC, MG32, Series B27 (Marcel Lambert fonds), Volume 81, File 7 - File Title: "Capital Punishment 1966," The Canadian Society for the Abolition of the Death Penalty, Information Bulletin 2 (panel discussion held in the Confederation Room, Parliament Buildings [West Block] at Ottawa on Thursday, June 3, 1965) (Toronto: Canadian Society for the Abolition of the Death Penalty, 1965), 26-31 (English translation of speech by René Lévesque); see also p. 50. This large quotation is from p. 31. Another abolitionist argued that "[t]he deliberate taking of the life of another, even in the name of society, cannot help but taint the burgeoning humanism of a world which is still struggling to raise man above the level of the beast" - John F. Donnelly, "Death Penalty Is a Brutalizing Influence on Society," Toronto Star, February 9, 1973, p. 6. Consider also the following statement by a retentionist: "I think if one looks at this form [sic] from the long range of perspective in man's history, there has been tremendous changes in the last 2000 years in man's treatment of others. Unfortunately we still have a long way to go before these animal characteristics of man's nature are completely submerged by more humane or human characteristics" - LAC, MG32, Series B40 (Alvin Hamilton fonds), Volume 186, File 10 - File Title: "Justice. Capital Punishment 1973-1984 Part I," Alvin Hamilton to T.D. Birmingham, June 21, 1976. Another Hamilton letter in the same file noted that MPs "are concerned with the rise of crime, but at the same time do not want to go back too far into the period of animal like revenge in our past history" - Alvin Hamilton to D.D. Cranfield, June 17, 1976.
} 


\section{Animality and the Dangerous/Wicked Human ${ }^{118}$}

Sometimes abolitionists brought up the idea of animality not to warn citizens away from vengeance and violence, but rather to deny the usefulness or desirability of emphasizing similarities between murderers and animals. ${ }^{119}$ Occasionally retentionists also showed apparent disapproval for the idea that people and animals belonged in similar categories. ${ }^{120}$ But many other retentionists did apply the term "animal" to murderers or point out parallels between the two groups. In one sense, this latter type of discussion might seem to represent an effort to prevent the debate from becoming too thoroughly centred on moralistic thinking. With the help of animal-themed terminology, some retentionists sought to locate the merits of capital punishment in a purportedly realistic perspective on murderers' character and future, rather than primarily in moral principles that might seem to place the capital-punishment tradition in a positive light. Nevertheless, moral assumptions and values actually did a great deal to make this discussion of animality attractive to retentionists. By implying that a society containing former murderers faced a hazard just as perpetual and unalterable as that created by the presence of an aggressive amoral animal, retentionists could simultaneously imply that

\footnotetext{
${ }^{118} \mathrm{My}$ use of the theme of dangerousness is perhaps stimulated in part by such discussions as Garland, Culture of Control, 135-137, and Garland, Punishment and Welfare, 85-87, the latter admittedly pertaining to a very different historical context than my thesis.

${ }^{19}$ See, for example, House of Commons Debates (4 April 1966), 3842 (S. Perry Ryan, MP Liberal, Spadina, ON); LAC, MG32, Series B35 (Walter Gilbert Dinsdale fonds), Volume 79, File 2 - File Title: "Capital Punishment. General 1973," copy of letter sent from A.B. Wilson to editor, Brandon Sun, January 22, 1973; House of Commons Debates (26 May 1976), 13871 (Howard Johnston, MP Progressive Conservative, Okanagan-Kootenay, BC); Christine Campbell, letter to the editor, Toronto Daily Star, July 6, 1976, p. B5.

${ }^{120}$ See House of Commons Debates (31 January 1973), 843 (Antonio Thomas, MP - Liberal, Maisonneuve-Rosemont, QC); see LAC, MG32, Series B27 (Marcel Lambert fonds), Volume 81, File 14 File Title: "Capital Punishment 1976 file 2," Ernest Kennedy to Max Saltsman, June 25, 1976.
} 
the desire to execute killers involved no vengefulness or approval of violence, but rather a practical desire to nip such hazards in the bud. ${ }^{121}$ Retentionists could thereby avoid some of the criticisms that might otherwise have arisen concerning their own moral character. On the other hand, animality could serve as a metaphor through which to call attention to murderers' participation in extreme immorality, and thus to imply that they had become suitable candidates for retributive execution.

Occasionally this implication of immorality emerged when retentionists suggested that killers had conducted themselves egregiously despite possessing the tools that enabled moral judgment or moral volition. One retentionist MP drew his colleagues' attention to the following statement, which he attributed to a Calgary Herald writer:

Contemporary society is producing a singularly savage type of animal, entirely lacking in comprehension of, or respect for, the lives of other people. These psychopaths know perfectly well what they are doing is wrong legally and morally, but the act of murder causes them no sense of personal revulsion. ${ }^{122}$

If such offenders' emotional rhythms gave them unusually little help in steering clear of homicide, the statement nevertheless emphasized their full lucidity concerning moral realities, perhaps with the implication that their wrongdoing qualified as fully volitional, although the statement did not confirm this explicitly. For one citizen, the animality that killers displayed clearly did co-exist with, and in fact resulted from, willful agency. "[П]f

\footnotetext{
${ }^{121}$ For one writer's observation of the potential, in the late twentieth century or the future, for capital punishment to qualify in some people's eyes as "humane extinction, the putting to sleep of a dangerous animal, the eradication of a pest," see Potter, Hanging in Judgment, 207.

${ }^{122}$ William Gold, quoted in House of Commons Debates (1 April 1976), 12394-12395 (Dan McKenzie, MP - Progressive Conservative, Winnipeg South Centre, MB). McKenzie used the quotation again a few months later - see House of Commons Debates (8 June 1976), 14247 (Dan McKenzie, MP). Note that I have not located the original article to determine whether in its broader context this quoted excerpt conveyed the same idea that it seemed to convey on its own.
} 
these beasts who have a choice to obey our laws and live as upright citizens do not care to do so then — why keep them around?" she asked. Admittedly, her letter may have implicitly displayed greater concern over killers' status as an unprofitable nuisance than over their immorality. ${ }^{123}$ But her words suggest that to at least a few citizens, animality connoted a type of conduct or character adopted by persons with "normal" access to human thought and volition. In embarking upon the animalistic journey, such persons had taken an immoral step.

Sometimes the term "animal" impressionistically emphasized simply the wickedness of murderers' deeds. "[T]he human animals who murder innocent people with axes, hammers, etc., and those who rape and kill innocent little children are treated too considerately in their executions," opined one letter writer. "They should be dispatched in the same manner which they used in committing the murders." 124 According to one retentionist MP, "rape that ends in murder is probably the worst crime of all," and "[a]nyone who rapes and murders in my mind is little more than an animal, and I have no compassion for him at all."125 While not directly stressing killers' moral agency, such statements hinted at the immorality involved in murder. Reminders of that immorality reassured retentionists that the execution of such individuals provided few grounds for compelling critique.

However, in applying such terms as "animal" to murderers, many retentionists

\footnotetext{
${ }^{123}$ LAC, MG32, Series B35 (Walter Gilbert Dinsdale fonds), Volume 79, File 2 - File Title: “Capital Punishment. General 1973," Hattie M. McFarland to Walter Dinsdale, January 1, 1973.

${ }^{124}$ Murray Caplan, letter to the editor, Globe and Mail, August 8, 1958, p. 6.

${ }^{125}$ House of Commons Debates (23 July 1973), 5901 (Bill Kempling, MP - Progressive Conservative, Halton-Wentworth, $\mathrm{ON}$ ).
} 
sought not so much to suggest that murderers had acted immorally, but rather to imply that such individuals might well end up playing a second or third round in the game of murder - a possibility with which Canadians would not flirt if they listened to their better judgment. With an anticipated peril of this nature on the table, affirmation of capital punishment would involve little ethical fault. As Ontarians argued in December 1962 about the execution whose lethal bite Arthur Lucas and Ronald Turpin experienced on the $11^{\text {th }}$ of the month, one retentionist used images of animality to parry the thrusts of the hanging's critics. "When are people going to realize that the law does not hang humans, only animals?" he asked. "You would destroy any animal that threatened your way of life; why not Lucas and Turpin?"126 A few years later, a British Columbian wrote to MP Davie Fulton concerning capital punishment, alluding in the process to two individuals through whose crimes a BC adolescent had suffered rape and death. "I do not feel myself to be blood-thirsty or vengeful," claimed Fulton's correspondent,

but when men such as the Meekers walk the earth I feel we need strong measures. I realize hanging men like the Meekers will not bring back the little girl they raped, tortured and murdered; but hanging them would ensure they didn't kill again. Until we can find and cure sexual psychopaths before they violate our children, our only recourse is extermination of vermin. ${ }^{127}$

\footnotetext{
${ }^{126}$ Robert King, letter to the editor, Toronto Daily Star, December 14, 1962, p. 6 (p. 99 in digital archive).

${ }^{127}$ LAC, MG32, Series B11 (E. Davie Fulton fonds), Volume 130, File Title: "Capital Punishment 1965-1966 Vol. 1," Barbara Hubert to Davey Fulton, April 6, 1966. The referred-to offenders were presumably Kenneth Meeker and Lennard James Meeker. Both had taken part in the girl's sexual abuse, but only Kenneth had carried out the murder. The case had become well known. See Canadian Press, "Death Sentence of B.C. Slayer Is Commuted," Globe and Mail, November 4, 1964, p. 1; see Sun Ottawa Bureau, "Meeker Escapes Gallows for Mission Sex Slaying," Vancouver Sun, November 4, 1964, p. 27; see LAC, RG2, Privy Council Office, Series A-5-a, Volume 6265, Cabinet Minutes, No. 105-64, November 3, 1964, p. 2-3; see Ruth Worth, "A Savage Releases the Savage in Others," Globe and Mail, November 21, 1964, p. 6; see Douglas Collins, "A Newspaper Lynching Party?" Globe and Mail, December 21, 1963, p. 8; see also Strange, "Lottery of Death," 612-613 n. 52.
} 
Canadians "do not hesitate to shoot a vicious dog or a rabid fox, wolf or other beast which is a menace to society," argued another retentionist. "Cold blooded murderers are just as much a menace to society. They are not prepared to respect the recognized rules of civilized behavior and therefore should be exterminated." 28 Through execution, authorities could take an important and ethically sound step to rectify a hazardous state of affairs.

Such claims implied that rehabilitative expectations for murderers would approach accuracy only if seasoned with a large portion of pessimism. In a few cases, retentionists directly combined references to animality with highly unencouraging words concerning the rehabilitative quest. In a speech to the House of Commons, retentionist MP Don Blenkarn made some positive comments about rehabilitative endeavours within the correctional system, but he had different ideas concerning a certain category of killers:

As for persons who commit heinous, premeditated, animal-like murders, there is not much chance of reforming them, and when we retain them within our penal system, the whole system has to be organized accordingly, with regrettable consequences. Maximum security precautions must be in force at all times to contain them, because we dare not let them out; they are animals. ${ }^{129}$

Said another retentionist picturesquely: "You cannot reform criminals by kindness any more than you can appease an alligator."

\footnotetext{
${ }^{128}$ H.H. Bairstow, letter to the editor, Toronto Daily Star, February 8, 1973, p. 7. For other examples of the use of animal analogies to portray execution as alleviating some element of homicidal danger, see C.S. Evans, letter to the editor, Globe and Mail, February 6, 1960, p. 6; House of Commons Debates (29 January 1973), 750 (Ross Whicher, MP - Liberal, Bruce, ON); (18 October 1973), 7008 (G.H. Whittaker, MP - Progressive Conservative, Okanagan Boundary, BC); Kenneth G. Frankum, letter to the editor, Toronto Daily Star, October 26, 1973, p. B5.

${ }^{129}$ House of Commons Debates (15 May 1973), 3770 (Don Blenkarn, MP - Progressive Conservative, Peel South, ON). See also 3771. For a comment linking the terms "animal" and "incorrigible" to a type of hypothetical killer, see House of Commons Debates (23 July 1973), 5882 (Ian Arrol, MP - Progressive Conservative, York East, ON).

${ }^{130}$ A.J. Reynolds, letter to the editor, Toronto Daily Star, February 23, 1960, p. 4.
} 
offender's murderous character, then retentionists could claim to have identified the specific societal advantage that execution would supply - deliverance from an individual who might well don the hat of homicidal assailant at some unpredictable point ahead.

If execution constituted an effort simply to withdraw the crucial factor around which a hazardous situation had materialized, some retentionists hoped that the offender being thus lethally withdrawn could die without the exacerbating experience of bodily discomfort. This preference for a "humane" termination could itself find validation in the analogy between murderers and animals. As one retentionist noted, "hanging ... is a barbaric process. We treat our animals better than this by putting them permanently to sleep with a needle." 131 He was not the only proponent of the death penalty ready to endorse such "better" treatment for killers. "If a man does cruel and destructive things because he cannot control his impulses, he is not fit to live and should be painlessly removed no less than a rabid dog or an unchecked weed," asserted one citizen. ${ }^{132}$ Another letter writer, who assured his readers that "I am not taking sides in this capital punishment debate," passed on a similar sentiment from a volume by George Bernard Shaw, whom the writer quoted as saying: "If a man is murderously violent we are not justified in turning his decent neighbor into a prison warder to keep him alive.... Such freaks should be pitied, and painlessly killed as a mad dog is killed."133 Once again retentionists could

${ }^{131}$ T.W. Stephens, letter to the editor, Toronto Daily Star, July 5, 1975, p. B3. See also Thomas Y. O'Hara, letter to the editor, Toronto Daily Star, February 29, 1960, p. 6.

${ }^{132}$ W. Humphrey, letter to the editor, Globe and Mail, April 28, 1958, p. 6.

${ }^{133}$ Marcus Van Steen, letter to the editor, Globe and Mail, January 16, 1963, p. 6. The quotation appears to be from Bernard Shaw, Everybody's Political What's What?, $2^{\text {nd }}$ ed. (1945; repr., London, UK: Constable and Company Limited, 1950), 281-282. In this edition, the last sentence I have quoted is actually "Such freaks should be pitied and painlessly killed without malice as a mad dog is killed" (p. 282). Since the letter says that the quote is from a 1944 book (the date of the first edition), the quote might be from the 
cast themselves in a virtuous light: if in the context of capital punishment they approved of death, they remained allies of those who wished to crowd out pain, even for murderers.

As some of the quotations in the preceding paragraphs suggest, the animal analogies used in the discussion of murderers and capital punishment could make murderers sound like amoral beings. The implacable "alligator," the "rabid dog," "freaks" - such verbal images might imply that murderers would display an impetuosity springing automatically from mood and desire, a ferocity involving no personal malice, and an unconcern emerging from obliviousness to moral option. But the letters or speeches in which such metaphors appeared often contained other comments or vocabulary that still implicitly located murderers' actions and outlook on the spectrum of morality and immorality. "The death penalty for murder is not a question of conscience," insisted one letter writer, but "simply one of self-preservation." After all, "[a] wolf, amok in a flock of sheep, is not merely caged for a specified period, but is destroyed immediately." If the analogy seemed to point to the killer's amorality, a statement later in the letter created a different impression. The Nazis had met with lethal opposition from the Allied world, and since murderers qualified as "[t]he enemy within," they "must surely deserve the same treatment."134 Did the term "deserve" hint that, comparable as killers might be to wolves, moral cognition and decision remained part of murderers' experience? Similarly, did "deserve" imply that the immorality of their homicidal actions

first edition, and perhaps the text in that edition might actually have been exactly as quoted in the letter. For another case in which a retentionist used a murderer-animal metaphor while advocating a pain-free death penalty, see House of Commons Debates (23 July 1973), 5896 (Stan Darling, MP - Progressive Conservative, Parry Sound-Muskoka, ON).

${ }^{134}$ Jack Mairs, letter to the editor, Toronto Daily Star, May 31, 1976, p. C5. 
truly counted as one of the factors showing the death penalty to be a commendable policy $?^{135}$

MP Allan Lawrence spoke of killers' character in an only somewhat less ambiguous vein. He referred to offenders whose lawyers had privately characterized them as " "pure brute"" or "all animal." Such criminals, Lawrence implied, stood as examples of the few Canadian convicts "whom it is not possible to rehabilitate." He did not seem ready to tout either amorality or stubbornness on the part of such offenders as the sole factor disqualifying them from the rehabilitative journey. "There are some people," he declared, "who choose to ignore the laws of society or fail to comprehend the standards of civilization. They simply cannot, will not or do not want to be rehabilitated."136 Another citizen seemed to emphasize killers' immorality but mixed in imagery perhaps suggesting amorality. "Capital punishment is what it implies punishment — and a right and just one for a beastly crime of taking another's life," she wrote. "We have no compunctions in destroying a mad dog who attacks us, then why all the hearts and flowers over predators who prey on the weak who cannot defend themselves?"137 In sum, references to the animalesque killer frequently created the

\footnotetext{
${ }^{135}$ For a related example, see LAC, MG32, Series B35 (Walter Gilbert Dinsdale fonds), Volume 79, File 2 - File Title: "Capital Punishment. General 1973," Reg Pearen to Walter Dinsdale, April 23, 1973. Even more ambiguously, see LAC, MG32, Series B27 (Marcel Lambert fonds), Volume 81, File 10 - File Title: "Capital Punishment 1973 file 2," A.L. Miller to Marcel Lambert, January 19, 1973.

${ }^{136}$ House of Commons Debates (18 October 1973), 6980 (Allan Lawrence, MP - Progressive Conservative, Northumberland-Durham, $\mathrm{ON}$ ). In the Debates, "pure brute" is part of a statement appearing in quotation marks, as if Lawrence is quoting a lawyer with whom he had spoken, while "all animal" does not appear in quotation marks. The latter words may thus be Lawrence's own.

${ }^{137}$ (Mrs.) G. Dutrizac, letter to the editor, Toronto Daily Star, March 29, 1966, p. 6. An op-ed by Charlotte Whitton provides another example of the use of animal-themed vocabulary in the discussion of both immorality and what she might have seen as quasi-amorality, although in this case the two are discussed in some distinction from one another rather than being quite as closely mixed together. Whitton believed that "sane, adult persons" should "be held capable of distinguishing between right and wrong" and
} 
impression of peril. The degree to which such vocabulary associated murderers with evil remained more varied and ambiguous. But whether in subtle or obvious forms, this latter association continued to surface in the rhetoric of animality.

And if the connotations of amorality and immorality often blended together, this only enhanced the usefulness of animal imagery for retentionists speaking within the context of the existing moral culture. On the one hand, the dominant theme of danger in their discussion of animality allowed them to steer clear of versions of retentionism animated primarily and explicitly by hostility to the evil quality of murderers' actions or attitudes. As we have seen, a thoroughly retributive retentionist stance of this latter variety could claim only shaky credibility within the culture of the day - a culture in which moral condemnation of other persons, especially condemnation punctuated by violence, elicited greater suspicion than in former eras.

On the other hand, the sometimes-subtle theme of immorality found in the animal analogies in retentionists' discourse allowed them to advance a low-visibility retributive perspective, and to couch it in a context that many Canadians would find compelling, even if they could not explain why. For in creating the verbal portrait of the possibly-

\footnotetext{
should "answer individually for their own wrongdoing." Such customs suited "a responsible free society" well. Given these views, it is not surprising that she considered capital punishment to be "warranted ... for any sane, responsible adult who, with deliberate plan, determines to wreak evil - the cold snake killer." But she immediately wrote of another genre of criminal: "I object also to abolition in the case of the animalistic brutal deviate, not only to protect society but as fundamental human economy in the use of personnel and resources of the community. I argue for the humane extermination of such deviates." Though it is not perfectly clear whether or not the "deviates" to whom she referred were individuals whom she also deemed "responsible," her wording and recommendations here and the apparent contrast being made with the "sane, responsible ... snake killer" suggest that she may be hinting at an amoral type of offender. See Charlotte Whitton, "Keep Capital Punishment," Brandon Sun, April 19, 1965, p. 4. A clipping of this article is also found in LAC, MG32, Series C31 (Heath Nelson Macquarrie fonds), Volume 42, File 31 - File Title: "Capital Punishment. 1965."
} 
amoral-but-really-immoral murderer/animal, retentionists drew upon the same implicit vision as did some abolitionists' discussion of animality. In both groups' estimation, if many facets of animal makeup and activity showed up within human life, people could nevertheless boast of much of which non-human beasts had no clue. And though the animal style could easily begin to smell sweet to people, pursuit of this alluring aroma would involve abandoning the norms and aspirations requisite to full human identity. The idea of animality cast humanness into relief, and humanness was both reality and requirement, a description of status and a demand to fulfill. The individual bucking this demand took a morally reprehensible step. Retentionist MP Rémi Paul quoted "Father Janvier, the prominent French sociologist and preacher":

"When a man, through his own viciousness, becomes a public menace, the regular authority cuts him out of the social body, just as a physician cuts out an eye, an arm or a leg when gangrene threatens the whole physical body. There is no injustice involved, because in falling into certain extremes which are repugnant both to reason and to the heart, the criminal has divested himself of human dignity and has fallen, so to speak, into animality. Having become similar to a wild beast, indeed even worse and more harmful, he deserves the same kind of treatment."138

By no means would all retentionists who spoke of animality have expressed matters so strongly, or even admitted to agreeing with this statement at all. But perhaps it points to a basic perspective from which Canadians continued to draw inspiration, even if unconsciously. It was difficult to regard a killer as truly amoral. If amorality seemed to characterize his current thought and deeds, the suspicion persisted that such amorality

\footnotetext{
${ }^{138}$ Quoted in House of Commons Debates (18 February 1960), 1218 (Rémi Paul, MP - Progressive Conservative, Berthier-Maskinongé-Delanaudière, QC). This is the translation found in the English version of House of Commons Debates. The quotation is part of a longer passage that Paul quoted, a passage that came, he indicated, from pages 116-118 of Justice et Droit, a book penned by Father Janvier (see also page 1284 in the French version of House of Commons Debates). I have not myself identified the book or verified whether the quotation is indeed found on these pages in the form given here.
} 
masked a still-active bit of immoral stubbornness, or at least that volition had partly fueled the step by which he had exited the human realm and "fallen ... into animality"139 in the first place.

In fact, occasionally even an abolitionist seemed to suggest this. One letter in the Toronto Star referred to the killer as "a person who lowers himself to animal level and takes another man's life." But the writer sought simultaneously to pound in a signature theme from the abolitionist melody: a theme about "us," the citizens other than the killer. A certain prominent member of the Torontonian policing community, said the writer, “claims to represent the Metro policeman's view on what society should do to a person who lowers himself to animal level and takes another man's life. He would like us to lower ourselves to the same animal level and murder the murderer."140 To abolitionists, this latter idea was a non-starter.

In short, abolitionists considered it morally urgent for even those not tempted by lawbreaking to ward off the broader risk of "lower[ing] ourselves to ... animal level,"141 and for humans actually to continue "rising," 142 putting greater distance between themselves and the animal zone. Retentionists put the same basic ethical value to a very different use when they obliquely stressed the reprehensibility of the killers who "ha[d] fallen ... into animality"143 already.

${ }^{139}$ Ibid.

${ }^{140}$ B. Campbell, letter to the editor, Toronto Star, February 19, 1976, p. B5.

${ }^{141} \mathrm{Ibid}$

${ }^{142}$ House of Commons Debates (31 January 1973), 848 (Ed Nelson, MP - NDP, BurnabySeymour, BC); see also (20 February 1973), 1483-1484 (Ed Nelson).

143."Father Janvier," Justice et Droit, quoted in House of Commons Debates (18 February 1960), 1218 (Rémi Paul, MP - Progressive Conservative, Berthier-Maskinongé-Delanaudière, QC). 
In the speech quoted at the outset of this chapter, MP Heath Macquarrie depicted the human as a responsible being who "is a little lower than the angels." varying degrees, most participants in the capital-punishment debate tacitly agreed that responsibility could be assumed to reside among the powers of at least "normal" people like themselves - although many debaters' outlook on this responsibility probably involved less consciousness of the angels or of God than had been the case for earlier generations. In any case, some Canadians also called attention to Earth-bound creatures as immediate points of reference in the discussion of human character and the ethical quandaries surrounding the death penalty. If indeed "[p]sychologists" taught "that man ... is just a little higher than the ape," perhaps the bulk of Macquarrie's fellow citizens would have shared his distaste for the "just a little" part of that description. ${ }^{145}$ But many of them considered it quite appropriate to think about the human and the animal in juxtaposition, and to remember that, whether the road from the animal realm to the human zone involved a small or a sharp gain in elevation, the two groups remained nextdoor neighbours along that road, with people being disturbingly capable of paying the beasts a metaphorical visit and even ending up joining them. Bearing this relationship in mind sometimes helped Canadians to fashion explanations for the mysterious, impulsive, or dangerous aspects of themselves or their fellow citizens. It also provided inspiration to remain wary of those human jolts of impulse, to urge society that its attitudes and practices required additional upgrade, or to denounce those persons who had cast in their

\footnotetext{
${ }^{144}$ House of Commons Debates (22 November 1967), 4577 (Heath Macquarrie, MP - Progressive Conservative, Queens, PEI).

${ }^{145}$ Ibid.
} 
lot with the animals. Such moral fervor was always close at hand when Canadians argued about the death penalty. 


\section{Chapter 5: Permissiveness and Public Opinion: Interpretations of Social Trends and Citizens' Attitudes in the Debates of the 1970s}

On July 6, 1976, Progressive Conservative MP Walter Dinsdale delivered one of the retentionist speeches that continued to proliferate in the House of Commons. Bill C-84, the legislative initiative that would turn the criminal code into a death-penalty-free body of law, had won the approval of the House during the second-reading vote on June 22. But the final vote of confirmation at third reading would not occur until July 16 , as retentionists used a long series of proposed amendments to try to enable the courts to use death sentences in at least some scenarios. To Dinsdale and others, the legislation appeared to fit poorly with the circumstances in which Canadians had found themselves of late. He spoke of "an increasing wave of permissiveness in Canada, North America and Europe during the last decade or so. There has been an increasing breakdown of law and order. Statistics for murder have doubled." And "statistics for attempted murder have not only doubled but quadrupled and a wave of violent crime, such as rape and similar acts of violence, has gone on apace."1

Dinsdale had also spoken against abolition on other occasions in the 1973 and 1976 parliamentary debates. ${ }^{2}$ But he had not professed a retentionist outlook over the entirety of his twenty-five-year parliamentary career. In fact, the shifts in Dinsdale's

\footnotetext{
${ }^{1}$ House of Commons Debates (6 July 1976), 15060 [see also 15061] (Walter Dinsdale, MP Progressive Conservative, Brandon-Souris, MB). For the second- and third-reading votes on Bill C-84, see Journals of the House of Commons of Canada, $1^{\text {st }}$ Session, $30^{\text {th }}$ Parliament, Volume 121, No. 328 (22 June 1976) and No. 341 (14 July 1976). For debate on the many proposed amendments, see House of Commons Debates between June 29 and July 13, 1976.

${ }^{2}$ See House of Commons Debates (22 May 1973), 3986-3987 (Walter Dinsdale, MP - Progressive Conservative, Brandon-Souris, MB); (24 July 1973), 5951-5953 (Walter Dinsdale, MP); (26 May 1976), 13872-13875 (Walter Dinsdale, MP).
} 
stance between 1956 and 1976 nicely reflected certain broader trends in parliamentarians' outlook on the controversy over those two decades. In a 1956 letter to a constituent, Dinsdale indicated that an abolitionist perspective seemed good to him in many respects, but he also pointed out the "strong legal argument in cases of deliberate premeditated homicide, that Capital [sic] punishment has a very necessary deterrent effect." ${ }^{\text {"3 }}$ This latter point seems to have remained compelling to him in 1960 , and he appears to have felt skepticism toward abolitionist MPs' efforts at this time to strip all lethal options from all sentencing for murder. But he looked more positively on a colleague's private member's bill that would have permitted only some types of murders to elicit death sentences, with death to occur through lethal gas rather than via the noose. $\mathrm{He}$ acknowledged, too, that the system by which murder was punished had to leave as little opportunity as possible for anyone erroneously suspected of murder to suffer a guilty verdict in court and a subsequent execution. The story of Wilbert Coffin, Dinsdale knew, had brought this issue home to various people. ${ }^{4}$ Yet by 1965 the Canadian Society for the Abolition of the Death Penalty could list Dinsdale among its members, ${ }^{5}$ and he also now labeled himself an abolitionist in some of his correspondence. At times he mentioned his involvement as a young man in outreach to offenders under the auspices of the Salvation

\footnotetext{
${ }^{3}$ LAC, MG32, Series B35 (Walter Gilbert Dinsdale fonds), Volume 78, File 12 - File Title: "Capital Punishment. General. n.d.; 1953-1967," Walter Dinsdale to Harold F. Smith, February 27, 1956; see also Harold F. Smith to Walter Dinsdale, February 24 [1956].

${ }^{4}$ See LAC, MG32, Series B35 (Walter Gilbert Dinsdale fonds), Volume 78, File 12 - File Title: "Capital Punishment. General. n.d.; 1953-1967," Walter Dinsdale to Miss M.E. Jollow, March 1, 1960; see Brandon Daily Sun, city edition, "Dinsdale Sees Commons Keeping Death Penalty," February 22, 1960, p. 1; see House of Commons Debates (2 February 1960), 611 (John Drysdale, MP - Progressive Conservative, Burnaby-Richmond, BC).

${ }^{5}$ LAC, MG32, Series B35 (Walter Gilbert Dinsdale fonds), Volume 78, File 12 -File Title: "Capital Punishment. General. n.d.; 1953-1967," P.T. Matlow, Secretary, The Canadian Society for the Abolition of the Death Penalty to Walter Dinsdale, January 2, 1965, and attached list of MPs and Senators.
} 
Army, noting that his memory of that activity provided part of the motivation behind his endorsement of abolition now. Perhaps equally tellingly, he indicated that abolition seemed desirable when considered in light of the taste he had received of the capitalpenalty system in the early 1960s while sitting in Diefenbaker's cabinet, where he had joined with fellow ministers in assessing the propriety of commutation or execution for various individual recipients of death sentences. ${ }^{6}$ Dinsdale still appears to have maintained a middle-of-the-road attitude concerning the issue, suggesting to one correspondent, in a seemingly approving tone, that a successful abolitionist initiative in Parliament would probably not quash the death penalty for the offence of murdering those persons guarding jails or serving on police forces. ${ }^{7}$ Here he came roughly into line with the prevailing outlook in Parliament, as evidenced by the passage of legislation in 1967 that largely matched his prediction. ${ }^{8}$

But when another anti-death-penalty legislative push loomed in 1973, voters found that Dinsdale had turned away from abolitionism. In mid-January the Brandon Sun, the major local newspaper within his riding, noted his shift. A "breakdown in law and order" was afoot, Dinsdale observed. Moreover, constituents had been recommending the retentionist perspective to him much more frequently than the

${ }^{6}$ LAC, MG32, Series B35 (Walter Gilbert Dinsdale fonds), Volume 78, File 12 - File Title: "Capital Punishment. General. n.d.; 1953-1967," Walter Dinsdale to Reverend S.A. Walmsley, April 9, 1965; Walter Dinsdale to Reverend C.N. Howard, April 14, 1965; Walter Dinsdale to Mr. C.E. Heapy, February 18, 1966. See also The Canadian Who's Who, vol. X, 1964-1966 (Toronto: Trans-Canada Press, 1966), s.v. "Dinsdale, Hon. Walter Gilbert."

${ }_{7}^{7}$ LAC, MG32, Series B35 (Walter Gilbert Dinsdale fonds), Volume 78, File 12 - File Title: "Capital Punishment. General. n.d.; 1953-1967," Walter Dinsdale to Reverend Carol B. Roberts, June 3, 1965; see also Walter Dinsdale to Mr. C.E. Heapy, February 18, 1966.

${ }^{8}$ See Chandler, Capital Punishment in Canada, 14; for Dinsdale's vote in favour of this legislation, see Journals of the House of Commons of Canada, $2^{\text {nd }}$ Session, $27^{\text {th }}$ Parliament, Volume 114, No. 86 (23 November 1967) and No. 91 (30 November 1967). 
abolitionist viewpoint..$^{9}$ Although we can only speculate, perhaps the decade that had elapsed since he had served in cabinet had made the abolitionist considerations generated by the commutation deliberations in which he had then engaged seem less compelling to him now. And perhaps the ever-lengthening period in which no Canadian murder convicts had actually undergone execution made citizens, including Dinsdale, less likely to worry that the investigation and prosecution of a given murder might take an erroneous turn and allow the executioner to kill an individual actually uninvolved in the crime, or that Coffinesque episodes of controversy might arise. In any case, Dinsdale would maintain a retentionist stance in both the 1973 and 1976 parliamentary debates. His speeches and statements would employ more than one of the key elements of retentionist rhetoric characteristic of the debate in the 1970s.

Dinsdale was not the only one who changed his tune between the 1960s and 1970s. Indeed, the Canadian death-penalty debate as a whole in the 1970s diverged somewhat from the character of the controversy during the preceding decade-and-a-half. Although debaters continued to reiterate the ideas employed in earlier years, two recent developments — both of them reflected in the Sun's reporting of Dinsdale's viewpoint added new dimensions to discussion. First, crime in Canada was indeed beginning to resemble a well-fertilized crop in ideal spring weather, blossoming into prominence both in statistical reports and within the public's field of vision. Second, a larger majority of Canadians seemed to be giving their nod of affirmation to the retentionist camp, if polling

${ }^{9}$ M. Haroon Siddiqi and Andy Moir, "Capital Punishment," Brandon Sun, January 18, 1973, p. 1. The quoted words are Dinsdale's, recorded in this article. 
reports and lobbying trends could be believed. These developments and the arguments that they stimulated infused the debate with a dynamic sufficiently distinctive to allow us to picture the post-1970 debate as belonging to a new historical period of some type. Either of two possible frameworks might prove useful for describing this new phase and its divergence from the pre-1970 years.

First, we might associate the post-1970 debate with a new phase in the history of Canadians' outlook on criminal justice. The unfolding of abolition during the two decades between 1957 and 1976 does not appear to have fallen within a single period in which Canadians steadily bought into a vision of penal amelioration. Instead, the abolitionist phenomenon may have occurred over two periods, the first involving greater desire to pry the tentacles of a punitive perspective off of some aspects of the correctional system, ${ }^{10}$ the second involving modest growth in the cultural credibility both of retributive thought and of muscular penal mentalities relative to rehabilitative expectations. Such a portrayal can find some support, although not without qualification, in the existing literature. Scholars have observed that after roughly the mid-1970s, certain key penal assumptions and policies in the United States, especially the expectation that time spent fulfilling a criminal sentence should constitute a rehabilitative phase in a convict's life, won much less ardent adherence than before. ${ }^{11}$ Some writers have conveyed a similar impression about the shape and chronology of recent Canadian

\footnotetext{
${ }^{10}$ David Chandler, for instance, claims that "[ $[$ ] $]$ he Canadian death penalty debate fits the latest phase of legal evolution in western democracies in which there is struggle to drop the symbolic punishment aspect of the law and make the "punishment' fit the criminal rather than the crime" - Chandler, Capital Punishment in Canada, xxii. Although contained within a mid-1970s book, his statement would seem to reflect pre-1970 mentalities more than their post-1970 counterparts.

${ }^{11}$ See Garland, Culture of Control, 8, 53-65.
} 
criminal-justice history. ${ }^{12}$ Sociologist David Garland provides a particularly important analysis of this phenomenon within the United States and Great Britain. Garland argues that, in contrast to the first seven decades of the century, and especially to the quarter century following World War II, post-1970 criminal justice has involved a tendency to endow punishment with a stiffer bite, to try more strenuously to block off avenues for recidivism, and to seek less urgently for actual rehabilitative adjustments in convicts' outlook and lifestyle. In short, punitiveness has gained greater currency. Part of the fuel for these trends came from the awareness in both the United States and Britain that the criminal law was suffering more frequent transgression than before. All these phenomena reflected key adjustments both in economic patterns and in cultural frameworks, but also materialized in significant part through political initiatives. ${ }^{13}$ The ethos of the Canadian death-penalty debate after 1970 bears a strong resemblance to that seen in the early stages of the "punitive turn" that Garland describes. ${ }^{14}$

It is more debatable whether these early signs in Canada were complemented by an ongoing metamorphosis that altered long-term criminal-justice mentalities sufficiently for us to use the concept of a new period when describing what unfolded. Garland's ideas should be used cautiously. According to a recent graduate thesis by Jeffrey Meyer, those who assume that Garland's description fits the realities of Canadian federal government

\footnotetext{
${ }^{12}$ See Ekstedt and Griffiths, Corrections in Canada, 49-54.

${ }^{13}$ See, for example, Garland, Culture of Control, vii-xii, 3, 6-9, 12, 61, 75-77, 89-92, 94-102, 142, 144, 147-158, 193-195, 201-203.

${ }^{14}$ The term "punitive turn" can be found on ibid., 142. However, in using this term to identify the phenomenon that Garland is discussing, I am following Jeffrey Meyer, "Evaluating the Punitive Turn Thesis: Is Canadian Penal Discourse Officially Exemplifying a Punitive Mentality?"' (M.A. Thesis, Carleton University, 2004).
} 
policy and Canadian correctional practice during the corresponding period will stray into historical inaccuracy. To Meyer, it seems, pre-1970 and post-1970 Canadian viewpoints concerning penal affairs lend themselves at least as much to comparison as to contrast. ${ }^{15}$ Still, he does suggest that Canadian criminal justice appears to have carved out somewhat more space for punitiveness in the latter portion of the century, if to a far tamer degree than Garland's readers would assume is true in the United States. ${ }^{16}$ Furthermore, Carolyn Strange creates a rather Garlandesque impression about Canadian realities in the late1980s and the 1990s. ${ }^{17}$ In sum, although Garland's discussion seems to shed significant light on the ethos of the death-penalty debates of the early and mid-1970s, that does not necessarily give cause to buy into his framework when attempting to conceptualize the Canadian criminal justice of later years. But if Canadian mentalities in the final three decades of the century functioned in even a partly Garlandesque mode, it would seem useful to view the tone of the death-penalty debate in the 1970s as reflecting and contributing to the birth of this new outlook.

As a second, more obvious periodizing framework, we might simply say that the explanation for the adjustments in debate rhetoric after 1970 lies in the general post1960s ethos. If many Canadians in the 1960s had majored in "optimism," daring, and "enthusiasm," many citizens in the 1970s soon began to feel that tomorrow might not be as pleasant as hoped, and some began to think that more guarded courses of action and

\footnotetext{
${ }^{15}$ See Meyer, "Evaluating the Punitive Turn Thesis," especially 21-22, 43-45, 86-91.

${ }^{16}$ See ibid., 2, 86-87, 90 .

${ }^{17}$ See Strange, "Introduction," 13-15, 17, 19-20 n. 31; see also 12.
} 
less optimistic attitudes might be in order today. ${ }^{18}$ Such events as the October Crisis probably helped to goad citizens toward this new outlook:; ${ }^{19}$ such economic vexations as inflation undoubtedly helped to solidify it. ${ }^{20}$ It might be debatable whether Canadians' experiences and mentalities of the early and mid-1970s helped to generate a frame of mind concerning criminal justice that was both sufficiently different from pre-1970 perspectives and sufficiently long-lasting to be meaningfully described as defining a new phase in Canadians' thinking about crime and penal affairs. But it is much clearer that Canadians sang about criminal justice, including the death penalty, in a slightly different key for at least part of the 1970s, and that the general circumstances and mind-sets of the post-1960s era bore part of the responsibility for this new sound.

The story to be told here, however, is of a mixture of change and continuity. Although the apparent deepening of crime's footprint upon Canadian society and the seeming success of the retentionist camp in winning public support constituted central aspects of the debate's context and ethos after 1970, this chapter will focus primarily on the contrasting interpretations that debaters attached to these two developments. Indeed, these interpretations formed the most colourful, pivotal, and revealing aspects of the discussion of capital punishment during these years. While these varying interpretations

\footnotetext{
${ }^{18}$ See Owram, Born at the Right Time, 160, 174, 280-281, 284-286, 303-304, 309-313, 390; he uses the terms "optimism" and "enthusiasm" on , for instance, 160 and 174. However, it is possible that Owram would not describe the early-1970s ethos in quite the manner I have. For the somewhat different but broadly related analysis by an MP at the time, see House of Commons Debates (29 May 1973), 42254226 (Gerald Baldwin, MP - Progressive Conservative, Peace River, AB); (24 July 1973), 5924 (Gerald Baldwin, MP).

${ }^{19}$ See Fattah, Study of a Social Attitude, 3-6.

${ }^{20}$ See Owram, Born at the Right Time, 306, 309; see House of Commons Debates (5 May 1976), 13217-13218 (David Collenette, MP - Liberal, York East, ON).
} 
revealed a strong interest in the concrete suppression of lawbreaking and promoted a continued focus on this practical goal, they also stemmed from the already wellentrenched moral interests and sensibilities that continued to shape the debate in both obvious and subtle ways. Statistical analyses performed by academics critically weakened retentionists' ability to use current data on the proliferation of murder to portray capital punishment as a mechanism of deterrence. Accordingly, abolitionists could stick with the strategy of focusing on deterrence and its failures. Interestingly, however, the abolitionist statistical case relied on the notion that the more frequent murders of recent times had arrived hand-in-hand with the expansion of violent crime of all stripes. This conception meshed with a now-prominent theme in parliamentarians' interpretation of rising crime: that Canadian society had damaged itself through "permissiveness." The concept of "permissiveness" possessed enough flexibility to be incorporated into different interpretations of society's problem, appearing in the rhetoric of social conservatives promoting transcendent moral thinking, of abolitionists portraying habits of violence as a fundamental flaw in current Canadian life, and of debaters highlighting concrete problems in criminal-justice practices. Debaters also expressed their moral positions, sometimes rather obliquely, when interpreting the significance of the apparent dominance of retentionist opinion among the populace. In seeking to emphasize their own practical mentality and either the retributive or utilitarian outlooks of others, various debate participants actually left evidence of the ways in which moral sensibilities animated or constrained their own position on the death penalty. In the end, therefore, although new events and mind-sets after 1970 brought new dimensions to the 
death-penalty debate, this adjusted discourse also reflected important continuities in moral outlook, as debaters crafted their discussion to fit with their established outlook concerning ethical foundations, violence, and vengefulness.

\section{Deterrence and Statistical Interpretations of Crime}

When legislators used Bill C-168 in 1967 to put death sentencing for most capital murder on the shelf until late in 1972 , they were venturing out in hope that the abolitionists' claims about capital punishment, deterrence, and murder would prove true. They were also creating an easy avenue for the eventual use of more frequent capital sentences once again should those claims fall flat. ${ }^{21}$ It turned out to be a poor period for proving the abolitionists' point: the murder rate did not behave as they had hoped. According to Statistics Canada (known as the Dominion Bureau of Statistics [DBS] until the early $1970 \mathrm{~s}^{22}$ ), in 1962 murder accounted for 1.17 deaths among every 100,000 Canadian residents. Affairs had moved a slight distance in the wrong direction by the end of 1967 , with that year's criminal activity putting the murder rate at 1.38 . Over the ensuing years, this rate often re-emerged in more disturbing magnitude: 1.52 in 1968, 2.03 in 1970, 2.19 in $1972,2.43$ in $1974 .^{23}$ Such numbers would still have seemed to give relative cause for

\footnotetext{
${ }^{21}$ See Strange, "Lottery of Death," 618; see House of Commons Debates (9 November 1967), 4077 (Larry Pennell, MP - Liberal, Brant-Haldimand, ON); (29 November 1967), 4858-4861; see editorial, "The Rope: Obviously Not a Deterrent," Globe and Mail, December 29, 1972, p. 6.

${ }^{22}$ Compare Dominion Bureau of Statistics, Judicial Division, Murder Statistics: 1970 (Ottawa: Information Canada, 1971); Statistics Canada, Judicial Division, Murder Statistics: 1971 (Ottawa: Information Canada, 1973).

${ }^{23}$ See Statistics Canada, Justice Statistics Division, Paul Reed, Teresa Bleszynski, and Robert Gaucher, Homicide in Canada: A Statistical Synopsis (Ottawa: [Queen's Printer], 1976), Foreword, 1-2, 713, especially 9. A rate of 2.8 materialized in 1975, although the Statistics Canada publication containing this figure did not appear until half a year after abolition arrived — see Statistics Canada, Justice Statistics Division, Murder Statistics: 1975 (Ottawa, [Queen's Printer], 1976), [1], 6. The corresponding figure for
} 
optimism when placed in juxtaposition with measurements of American murder. ${ }^{24}$ But by the time of the final round of the debate, the data appeared to suggest that Johnny Canuck had been only half as likely to die at a murderer's instigation in 1962 as in $1974 .{ }^{25}$

Although one suspects that the majority of citizens remained largely oblivious to the murder rate, the data was already starting to give some abolitionists fits by 1970 . For example, on September 8 of that year, a Canadian Press piece discussed the discoveries of the DBS about the murders occurring during the final four years of the 1960 s. If 1966 had seen 220 murders, the next three years had brought 281,314 , and 341 , respectively. ${ }^{26}$ This was the type of information that made some retentionists look prescient, and that some abolitionists felt compelled to challenge. As we shall see momentarily, in this case the Globe and Mail editorial writer took up the latter task with particularly vehemence.

Retentionists had certainly not waited until the 1970s to speak of an "increase in crime in Canada." ${ }^{27}$ General references to this alleged problem surfaced in parliamentary

1976 was 2.66 - see Statistics Canada, Justice Statistics Division, Homicide Statistics: 1976 (Ottawa, [Supply and Services Canada], 1978), 28. Again, debaters could discover this last figure only later.

${ }^{24}$ See Fattah, Study of the Deterrent Effect, 107; see Statistics Canada, Homicide in Canada: A Statistical Synopsis, 16.

${ }^{25}$ For two instances in which the 1962 and 1974 statistics appear in a retentionist speech, see House of Commons Debates (10 June 1976), 14347 (Hugh Anderson, MP - Liberal, Comox-Alberni, BC); (17 June 1976), 14591 (Peter Bawden, MP - Progressive Conservative, Calgary South, AB). For two instances in which an MP pointed out this type of change (albeit by making reference to statistics for 1965 and 1974), see House of Commons Debates (5 May 1976), 13219 (Douglas Roche, MP - Progressive Conservative, Edmonton-Strathcona, AB); (10 May 1976), 13350 (Stan Darling, MP - Progressive Conservative, Parry Sound-Muskoka, ON). For an instance in which an abolitionist noted the statistics for 1962 and 1974 but suggested that the shift was "not entirely but partly ... a result of the police laying more murder charges" in cases in which manslaughter charges would also have been plausible (at least in terms of earlier police habits), see House of Commons Debates (25 May 1976), 13819 (Stuart Leggatt, MP-NDP, New Westminster, BC). See also Statistics Canada, Homicide in Canada: A Statistical Synopsis, 9.

${ }^{26}$ Canadian Press, "Murders on Increase, DBS Statistics Reveal," Globe and Mail, September 8, 1970, p. 5; Canadian Press, "Murder in Canada on Rise, 341 Counted in Last Year," Toronto Daily Star, September 8, 1970, p. 4.

${ }^{27}$ House of Commons Debates (5 April 1966), 3902 (Hugh John Flemming, MP - Progressive Conservative, Victoria-Carleton, NB). 
speeches in the $1960 \mathrm{~s},{ }^{28}$ but occasionally more specific statistical claims came forward as well. $^{29}$ One claim of the latter variety reached the table late in 1964 partly through the efforts of two retentionist heavyweights - MP Ralph Cowan and the Canadian Association of Chiefs of Police. With 118 murders in 1960 but 231 in 1963, it was time to acknowledge the merits of capital punishment, Cowan believed. The police chiefs were happy to suggest the same when airing their views with the Prime Minister and the Minister of Justice. But the Canadian Society for the Abolition of the Death Penalty (CSADP) could fight back effectively, arguing that through a combination of tapping into less-than-first-rate data and failing to interpret it properly, Cowan and company had gone badly off the factual rails. With the CSADP's rebuttals being disseminated both in the press and to parliamentarians, ${ }^{30}$ Canadians interested in the capital-punishment issue

\footnotetext{
${ }^{28}$ See, for example, House of Commons Debates (4 April 1966), 3847 (Eric Stefanson, MP Progressive Conservative, Selkirk, MB); (5 April 1966), 3895 (Théogène Ricard, MP - Progressive Conservative, Saint-Hyacinthe-Bagot, QC); (14 November 1967), 4286 (Yves Forest, MP - Liberal, Stanstead, QC).

${ }^{29}$ See House of Commons Debates (14 November 1967), 4249 (Martial Asselin, MP - Progressive Conservative, Charlevoix, QC).

${ }^{30}$ See Elmer L. Steeves, Canadian Association of Chiefs of Police to Lester B. Pearson, December 17, 1964, as reprinted in Department of Christian Social Service, Anglican Church of Canada, The Death Penalty? (Toronto: Department of Christian Social Service, Anglican Church of Canada, n.d. [1965?]), 1012; see National Research Committee, Canadian Society for the Abolition of the Death Penalty, "A Reply to the Submission of the Canadian Association of Chiefs of Police Dated February 6, 1965, and Addressed to all Members of Parliament at the Parliament Buildings, Ottawa," April 26, 1965, as reprinted in Department of Christian Social Service, Anglican Church of Canada, The Death Penalty? (Toronto: Department of Christian Social Service, Anglican Church of Canada, n.d. [1965?]), 20-29 (a copy of this document is also found in LAC, MG32, Series C31 [Heath Nelson Macquarrie fonds], Volume 42, File 31 -File Title: "Capital Punishment. 1965," as an attachment to P.T. Matlow, Canadian Society for the Abolition of the Death Penalty, to All Members of the Canadian House of Commons and Senate, May 3, 1965); see also Toronto Daily Star, "Police Accused of Lobbying to Keep Gallows," May 7, 1965, p. 52 (a clipping of this article is found in LAC, MG31, Series K24 [June Callwood fonds], Volume 27, File 4 - File Title: "Capital Punishment. Scripts by JC, correspondence, reference materials [3] n.d., 1963-1988"); see also editorial, "Cowan and Police Chiefs Off Base," Toronto Daily Star, May 8, 1965, p. 6; see also Arthur Maloney, "Does Retention Protect Police?" The Canadian Register (Kingston, ON), February 5, 1966, p. 5 (a clipping of this article is found in LAC, MG32, Series C31 [Heath Nelson Macquarrie fonds], Volume 42, File 32 - File Title: "Capital Punishment 1966").
} 
could not quite so easily feel truly frightened over murder data from the first half of the 1960s.

If critique of retentionists' actual data had worked well for abolitionists before, the Globe and Mail hoped that a similar strategy would pay off now as Canadians were hearing about the seemingly more menacing DBS data concerning the late $1960 \mathrm{~s}$. When the Canadian Press piece discussing these statistics ran on September 8, 1970, the Globe editorialist decided that the situation warranted strong words. The quantitative picture that the DBS sketched concerning murder carried less credibility than "your local ouija board," the editorialist suggested. "Your ouija board at least delivers an unprejudiced opinion; your Dominion Bureau of Statistics delivers the opinion of Canada's police departments which overwhelmingly favor the old rules on hanging." ${ }^{31}$ Only by learning about all or most individual Canadian killings in a given year could the DBS generate statistical insight concerning murder, and in order to gain the initial information pertaining to each case, the DBS primarily turned neither to provincial authorities working with death records nor to court functionaries dealing with criminal proceedings, but rather to police forces. ${ }^{32}$ The editorialist suspected that, faced with a corpse left behind by suspicious circumstances or criminal violence, police preferred to postulate murder, and that what the DBS learned from the police too often involved inaccurate postulations of murder that crowded out the realities of manslaughter or other causes of death. ${ }^{33}$ After all, thought the Globe, the staunchly retentionist police would be delighted

\footnotetext{
${ }^{31}$ Editorial, "The Figures Are False," Globe and Mail, September 10, 1970, p. 6.

${ }^{32}$ See ibid.; see Statistics Canada, Homicide in Canada: A Statistical Synopsis, Foreword, $2,7$.

${ }^{33}$ See editorial, "The Figures Are False," Globe and Mail, September 10, 1970, p. 6.
} 
if Canadians came to feel that the nation's early experiences with abolition smelled too strongly of murder.

The Globe editorial page had already discussed Canadian murder statistics on at least one occasion earlier in $1970,{ }^{34}$ and it would feel the need to do so again at least four more times over the next two-and-a-half years. Although the paper again suggested that the police were injecting some fiction into the supposed statistical reality provided by the DBS ${ }^{35}$ the Globe also explained in greater detail why it considered some of the statistical impressions to be laced with fictional streaks. For one thing, the paper believed that those who focused upon murder in aggregate would confuse themselves concerning deterrence. In the Globe's view, the greater portion of Canadian killings featured the crucial input of alcohol, mental ill-health, fight-ignited fury, or similar stimulants, and the editorialist considered it "obvious" that aggression would never wilt in such scenarios even if the nation were stolidly faithful to capital-punishment tradition. To deal with these types of killings in analyses of deterrence made little sense. Indeed, the Globe suspected that if many such killings looked enough like murder to play the part in police publicity, a portion of these probably did not truly merit more than a manslaughter charge, whatever police officers or prosecuting counsel might think. ${ }^{36}$ By November 1972 the paper observed unhappily that it appeared to be popular to picture Canadian

\footnotetext{
${ }^{34}$ Editorial, "Murder?", Globe and Mail, April 4, 1970, p. 6. The paper here made essentially the same argument as in the October 10 editorial.

${ }^{35}$ See editorial, "False Murder Statistics Build a False Case," Globe and Mail, October 30, 1971, p. 6; editorial, "Statistics Most Foul," Globe and Mail, January 24, 1972, p. 6; editorial, "The Rope: Obviously Not a Deterrent," Globe and Mail, December 29, 1972, p. 6.

${ }^{36}$ See editorial, "False Murder Statistics Build a False Case," Globe and Mail, October 30, 1971, p. 6; see editorial, "Statistics Most Foul," Globe and Mail, January 24, 1972, p. 6.
} 
crime as big, bad, and ever more darkly triumphant. ${ }^{37}$ In December, however, the editorialist delightedly discussed a written analysis that the Canadian Criminology and Corrections Association had printed the month before. Murders might have loomed large in DBS analyses pertaining to the final four years of the preceding decade, but the number of persons actually receiving a murder sentence from the courts with respect to these killings amounted to a mere one sixth of the number of supposed murder cases reflected in the DBS statistics. The police, believed the Globe, had cried murder rather often, but with well under a twenty percent rate of accuracy. With murder so much feebler than standard statistical summaries seemed to suggest, the Globe felt all the more confident in insisting that the death penalty was "obviously not a deterrent."38

Whether or not anyone put much stock in the arguments of the Globe, these arguments illustrated the urge of some abolitionists to deny or downplay the notion that the country was getting a bigger annual helping of murder than prior to 1967 . But this would not turn out to be abolitionists' only way of thinking about the problem. More crucial to the emerging character of the debate was an interpretation advanced by criminologist Ezzat Abdel Fattah. As befitted a criminologist, Fattah was a greater fan of social science than of law and jurisprudence, although his outlook did not stem from ignorance of the juridical realm since he appears to have practiced criminal law in his

\footnotetext{
1972 , p. 6.

${ }^{37}$ Editorial, "Statistics Prove Nothing About Capital Punishment," Globe and Mail, November 30,

${ }^{38}$ Editorial, "The Rope: Obviously Not a Deterrent," Globe and Mail, December 29, 1972, p. 6; see Canadian Criminology and Corrections Association, The Death Penalty: An Official Statement of Policy of the Canadian Criminology and Corrections Association, November 1972, p. 2; see also Dominion Bureau of Statistics, Judicial Division, Murder Statistics, 1970 (Ottawa: Information Canada, 1971), 10-12.
} 
native Egypt in early adulthood. ${ }^{39}$ Now a member of the Canadian academic community, Fattah tried his hand at solving the empirical and analytical puzzle of murder, capital punishment, and deterrence. In embarking on the project, Fattah was not merely delving into a topic that he found compelling; he was also creating a product coveted by the Department of the Solicitor General of Canada, which demonstrated its interest through the contract by which it remunerated Fattah and ensured that he would complete a report. A Study of the Deterrent Effect of Capital Punishment with Special Reference to the Canadian Situation came off the press in 1972, and it would indeed help to equip the Solicitor General for his upcoming abolitionist efforts. ${ }^{40}$

Fattah hoped for abolition just as fervently as the Globe, but the methodology of his study stood at odds with certain key arguments through which the Globe and some other abolitionist voices addressed the deterrence issue and recent murder statistics. For example, Fattah did not consider DBS murder statistics to be fatally compromised by their derivation from the discoveries and descriptions of police forces. Indeed, in his view those hoping to learn about the crime occurring in the nation would gain the greatest enlightenment by tapping into information originating from the police. Fattah briefly discussed two other studies containing analyses of mid-century Canadian crime. He was happy to note their suggestion that the later portions of the periods of study had witnessed no significantly more acute violent-crime problem than had the earlier years.

\footnotetext{
${ }^{39}$ See Don Bell, "There Wouldn't Be Crime Without Victims," The Globe and Mail Weekend Magazine 22, no. 29 (July 15, 1972): 18-19.

${ }^{40}$ Ezzat Abdel Fattah, A Study of the Deterrent Effect of Capital Punishment with Special Reference to the Canadian Situation (Ottawa: Information Canada, 1972) - see especially iii, v, ix; see House of Commons Debates (26 January 1973), 689 (Warren Allmand, MP - Liberal, Notre-Dame-deGrâce, QC); (21 April 1975), 5032-5033; (29 April 1976), 12994.
} 
But he also noted that "[u]nfortunately" the researchers had chosen to channel their empirical efforts into investigating court-derived data. In Fattah's eyes, such a strategy would tend to constitute a methodological weakness. He certainly recognized that police read murder into some fatalities that had actually resulted from no more than manslaughter. But he also knew that many individuals with a genuine murder on their consciences never found themselves declared legally guilty of murder by a judge or jury, and that murder charges or sentences materialized more readily in some times and places than in others. In the end, believed Fattah, the police missed the quantitative bull's-eye by significantly less than did the courts. ${ }^{41}$ Furthermore, in seeming contrast to the Globe, Fattah believed that both murders and "non-negligent manslaughters" fit within the scope of his topic, both being "crimes in which the victim is killed by a voluntary act of violence." He suggested that "if capital punishment is a deterrent, it will clearly be relevant to all forms of voluntary killing." ${ }^{42}$ With this justification supplementing other rationales centring upon data constraints, he chose to deal not primarily with statistics concerning murder per se, but rather with those pertaining to "criminal homicide," the type of offence of which both the murderer and the manslaughterer were guilty. ${ }^{43}$ In short, Fattah's methodology did little if anything to pare down the statistical magnitude of the homicide unfolding in Canada.

Admittedly, he had no wish to overemphasize the murder problem: he refused to

\footnotetext{
${ }^{41}$ Ibid., 73, 78, 80-83, 85, 89. The "[u]nfortunately" is found on page 80. See also Statistics Canada, Homicide in Canada: A Statistical Synopsis, 7, 10, 12.

${ }^{42}$ Fattah, Study of the Deterrent Effect, 83.

${ }^{43}$ See ibid., 83, 85, 89.
} 
view the situation as "alarming," characterizing it instead as involving "a slight increase in criminal homicide in Canada over the past eight years." ${ }^{24}$ And he certainly did seek to debunk the deterrent credentials of the death penalty. However, his report accomplished this task not so much by portraying murder as only a minor current problem, but rather by revealing the seriousness of recent foreboding developments pertaining to violent crimes that did not involve homicide. Murder might be biting a larger proportion of Canadians, but statistics revealed that even greater troubles were emerging in violent criminal activity of non-lethal varieties. Canada had experienced increasing, if hardly overwhelming, struggles with crime during the 1960s, rendering 1970 a markedly worse year than 1962 , for example -35 percent worse if one were to consider homicide rates, but 118 percent worse if one were to examine aggregate violent-crime rates. This pattern seemed at odds with the ideas of retentionists who believed in deterrence. Such citizens considered it quite logical that with the death penalty now lying dormant, Canadians would become readier to plunge into murder, with the first development serving as the primary catalyst for the second. But had such a dynamic truly been in play, things should have been more speedily turning sour on the murder front than with regard to other offences - quite the opposite, that is, of what statistics revealed to be happening in Canada. Accordingly, reasoned Fattah, the decision to put capital punishment on the shelf could not be considered a meaningful ingredient among the factors from which Canada's homicidal

\footnotetext{
${ }^{44}$ Ibid., 116, 191.
} 
troubles had arisen.$^{45}$ Supplementing this primary line of reasoning with additional arguments, Fattah forcefully took his stand against the belief in death-penalty-related deterrence. $^{46}$

Fattah's report left a significant mark upon the capital-punishment debate, especially in Parliament. Listening MPs encountered sizeable quotations from the report during the main speech that Solicitor General Warren Allmand, number-one abolitionist of the 1970s, offered to the House of Commons during the 1973 debate. ${ }^{47}$ Various other parliamentarians cited Fattah's work as well, especially in $1973,{ }^{48}$ as did some of the better-informed non-politicians involved in the public debate. ${ }^{49}$ Occasionally

${ }^{45}$ See ibid., 92-95, 107, 116-117, 191. See also LAC, MG32, Series B35 (Walter Gilbert Dinsdale fonds), Volume 79, File 5 - File Title: "Capital Punishment. General. Feb.-July 1976," "Statement on Capital Punishment from Canadian Association of Elizabeth Fry Societies" [1973], attached to Margaret McKee (Mrs.), President, C.A.E.F.S. to All Members of Parliament, February 20, 1976 - this statement is also quoted in House of Commons Debates (7 June 1976), 14229 (Flora MacDonald, MP - Progressive Conservative, Kingston and the Islands, ON).

${ }^{46}$ Fattah, Study of the Deterrent Effect, 191-194.

${ }^{47}$ See House of Commons Debates (26 January 1973), 689-690 (Warren Allmand, MP - Liberal, Notre-Dame-de-Grâce, QC).

${ }^{48}$ At least twenty-one parliamentary speeches, including sixteen in 1973, mentioned Fattah's work on deterrence. For the best examples of abolitionist speeches discussing the aspect of his argument that 1 have outlined, see House of Commons Debates (31 January 1973), 845 (Terry O'Connor, MP - Progressive Conservative, Halton, ON); (14 May 1973), 3719 (Heath Macquarrie, MP - Progressive Conservative, Hillsborough, PEI); (22 May 1973), 3967 (Flora MacDonald, MP - Progressive Conservative, Kingston and the Islands, ON); (22 May 1973), 3977 (Douglas Roche, MP - Progressive Conservative, EdmontonStrathcona, AB). David Chandler also notes the frequent citation of Fattah's work in the 1973 debate see Chandler, Capital Punishment in Canada, 26.

${ }^{49} \mathrm{See}$, for example, J.A. Davidson, "Christian Perspective on Death Penalty," Globe and Mail, January 6, 1973, p. 7; see LAC, MG32, Series B35 (Walter Gilbert Dinsdale fonds), Volume 79, File 2 File Title: "Capital Punishment. General 1973," Ontario Association of Professional Social Workers, "Statement on Capital Punishment," news release, January 8, 1973, attached to Mae Harman, Executive Director, Ontario Association of Professional Social Workers, to "Dear Member of Parliament," January 9, 1973; see Arthur Maloney, "Death Penalty: Facts Can't Justify Even Partial Retention," Toronto Star, January 19, 1973, p. 6; see Peter M. Jacobson, "Balancing the Benefits and Costs of the Death Penalty," Toronto Star, November 4, 1975, p. B4. 
abolitionists echoed the main argument without specifically mentioning Fattah. ${ }^{50}$ The report's importance consisted not simply in the actual number of occasions on which debaters referred to it, but rather in the overall role it played in giving abolitionists confidence to maintain their long-standing arguments concerning the benign consequences of abolition. With crime bestowing many more dead bodies upon the nation now than prior to 1967 , abolitionists benefitted immensely from the existence of a respected study that rebutted retentionist ideas about deterrence without ignoring the high body count.

Correspondingly, retentionists got surprisingly little mileage out of the post-1967 DBS homicide data. At first blush, that data would appear to have offered retentionists easy thetorical victory, considering abolitionists' heavy investment in the claim that abolition was a policy free of any serious disadvantages. ${ }^{51}$ The dissemination of Fattah's argument probably did much to sabotage retentionists' opportunity. ${ }^{52}$ This is certainly not to say that the retentionist camp ceased to make statistical claims, nor that it ceased to

${ }^{50}$ See Cheryl-Ann White on behalf of Youth Corps Prison group and Bob Carty on behalf of Youth Corps staff and directors, letter to the editor, Toronto Star, January 25, 1973, p. 7; see Alan W. Craig, letter to the editor, Toronto Star, June 25, 1975, p. B5; see LAC, MG32, Series B35 (Walter Gilbert Dinsdale fonds), Volume 79, File 5 - File Title: "Capital Punishment. General. Feb.-July 1976," "Statement on Capital Punishment from Canadian Association of Elizabeth Fry Societies" [1973], attached to Margaret McKee (Mrs.), President, C.A.E.F.S. to All Members of Parliament, February 20, 1976 - this statement is also quoted in House of Commons Debates (7 June 1976), 14229 (Flora MacDonald, MP - Progressive Conservative, Kingston and the Islands, $O N$ ). For an inaccurate statement that nevertheless contrasts the bad recent developments concerning violent crime with the not-as-bad developments concerning murder, see House of Commons Debates (15 May 1973), 3762 (Grace MacInnis, MP - NDP, Vancouver Kingsway, $\mathrm{BC})$.

${ }^{51}$ On abolitionists' heavy investment in such a claim, see Arthur Maloney, "Does Retention Protect Police?" The Canadian Register (Kingston, ON), February 5, 1966, p. 5- a clipping of this article is found in LAC, MG32, Series C31 (Heath Nelson Macquarrie fonds), Volume 42, File 32 - File Title: "Capital Punishment 1966." See also Fattah, Study of a Social Attitude, 76.

${ }^{52}$ For an example that seems to illustrate this well, see House of Commons Debates (25 May 1976), 13813-13814 (Jack Murta, MP - Progressive Conservative, Lisgar, MB). 
regard deterrence as a prominent and meaningful pro-death-penalty word. And Fattah's report and other statistical ideas probably made a lesser impression upon most citizens than upon MPs. But it is noteworthy that, although discussion of deterrence continued to absorb much of retentionist MPs' debating energy, on the whole they did not discuss post-1967 murder data with anything approaching the triumphant tone and assured relentlessness that might have been anticipated. In fact, a number of retentionist MPs in the 1970s sought to show how deterrent dynamics might have existed in the recent Canadian past, or how they might emerge in a retentionist future, without these dynamics necessarily being empirically detectable via murder statistics, or at least not via the statistics of the past decade. ${ }^{53}$ Such arguments, while not new, ${ }^{54}$ implicitly conceded that the current statistical scene actually contained no better news for retentionists than for abolitionists..$^{55}$

Hence, the reverberations of Fattah's report in the debate took two forms. First, his arguments helped to enable the rhythms and structure of the debate to remain largely the same as in the 1960s, with each camp remaining faithful to its established overall stance on the still-central issue of deterrence, and with abolitionists at least slightly

\footnotetext{
${ }^{53}$ See, for example, House of Commons Debates (26 January 1973), 694-695, 697 (Erik Nielsen, MP - Progressive Conservative, Yukon, YT); (31 January 1973), 831-832 (Donald W. Munro, MP Progressive Conservative, Esquimalt-Saanich, BC); (14 May 1976), 13538-13539 (Alex Patterson, MP Progressive Conservative, Fraser Valley East, BC); (31 May 1976), 13985 (Marcel Roy, MP - Liberal, Laval, QC). David Chandler also points out the use of this type of reasoning - see Chandler, Capital Punishment in Canada, 27.

${ }^{54}$ See House of Commons Debates (5 April 1966), 3885 (Marcel Lambert, MP - Progressive Conservative, Edmonton West, AB); (16 November 1967), 4380-4381 (Jack Horner, MP - Progressive Conservative, Acadia, AB); (22 November 1967), 4570-4571 (Jack Horner, MP).

${ }^{55}$ For comments pointing in this direction more explicitly, see House of Commons Debates (25 May 1976), 13818 (Bill Clarke, MP - Progressive Conservative, Vancouver Quadra, BC); relatedly but somewhat differently, see House of Commons Debates (10 May 1976), 13350-13351 (Stan Darling, MP Progressive Conservative, Parry Sound-Muskoka, ON).
} 
augmenting their existing lead in that particular rhetorical contest. Second, the report added one more piece of legitimacy to the now-widespread readiness to acknowledge that a crime bug had bitten Canada. ${ }^{56}$ If Fattah's report kept retentionists from talking about murder rates quite as confidently and persistently as they otherwise might have, it also made some abolitionists more willing than they otherwise might have been to discuss the tentacles of crime that seemed to be sticking more tenaciously to 1970s Canada. Fattah thus helped to bring the well-entrenched discourse about deterrence into harmony with a modified discourse about Canadian crime and, as we shall see, with a new discourse about "permissiveness."

As helpful as Fattah's study was to abolitionists, the remainder of the debate did not offer them fully smooth sailing with respect to the deterrence controversy. Quantitative news emanating from Statistics Canada grew more disheartening rather than less. Furthermore, in 1975 American academia offered something distinctly less welcome among abolitionists than Thorsten Sellin's ideas had been. Economist Isaac Ehrlich believed that scholars might not yet have accurately comprehended what American murder data had to tell them about deterrence, and he thought that econometric analysis of statistics from the 1933-1969 period could open their eyes. The American Economic Review article in which Ehrlich examined the matter threaded its way through the type of mathematical maze that was familiar enough to those skilled in econometrics but probably mystifying to the average citizen interested in the death-penalty controversy.

\footnotetext{
${ }^{56}$ On this widespread viewpoint, see editorial, "Statistics Prove Nothing about Capital Punishment," Globe and Mail, November 30, 1972, p. 6.
} 
Yet one statement toward the end of the article had an especially good chance of making an impression upon the non-specialist reader. "[A]n additional execution per year over the period in question," suggested Ehrlich, "may have resulted, on average, in 7 or 8 fewer murders." ${ }^{57}$

The existence of this quickly famous claim in a recent academic study might have been expected to add significant horsepower to retentionist advocacy. But Canadian abolitionists succeeded remarkably well in shooting down the new threat. They certainly profited from the promptness with which other American academics sought to rebut Ehrlich's article. ${ }^{58}$ The Solicitor General's department, desiring a report on the Ehrlichcentred dispute, turned to Toronto-based consultant Robert Hann, who made plenty of room in his March 1976 report for Ehrlich-debunking arguments gleaned from the academic papers that had sprouted in the economist's wake. ${ }^{59}$ Thus equipped, Solicitor General Warren Allmand dealt with the issue at the outset of the 1976 parliamentary

\footnotetext{
${ }^{57}$ Isaac Ehrlich, "The Deterrent Effect of Capital Punishment: A Question of Life and Death," American Economic Review 65, no. 3 (June 1975): 414 - see also especially pp. 397-398, 406, 409-410, 416. See also Robert G. Hann, Deterrence and the Death Penalty: A Critical Review of the Research of Isaac Ehrlich ("A Research Report prepared under contract with the Research Division of the Solicitor General of Canada") (Ottawa: March, 1976), i. pages 2-3, I. page 3, VI. page 4; see also Banner, Death Penalty: An American History, 279-280. For some additional evidence that most citizens living at that time would probably have been quickly left in the intellectual dust (as I was) had they attempted to read the main body of Ehrlich's discussion, see LAC, MG32, Series B35 (Walter Gilbert Dinsdale fonds), Volume 79, File 5 - File Title: "Capital Punishment. General. Feb.-July 1976," transcript of 25 May 1976 meeting for parliamentarians in Railway Committee Room with panel of speakers sponsored by Canadian Society for the Abolition of the Death Penalty, pp. 27-28 (speech by Harold Veal).

${ }^{58}$ Stuart Banner writes that "Ehrlich's work received an enormous amount of public attention for a technical article in an economics journal" and notes the speed with which a rebuttal emerged - see Banner, Death Penalty: An American History, 280, 366 n. 19.

${ }^{59}$ See Robert G. Hann, Deterrence and the Death Penalty: A Critical Review of the Research of Isaac Ehrlich ("A Research Report prepared under contract with the Research Division of the Solicitor General of Canada") (Ottawa: March, 1976), especially i. pages 2-4, I. pages 3, 6, 15-17, V. page 5-6, VI. pages 12, 15-20, 22-23, VII. pages 1-2.
} 
debate, informing his fellow MPs why they should refuse to buy into Ehrlich's account. ${ }^{60}$ Parliamentarians received a further dose of the Ehrlich-refuting message at a CSADP event. ${ }^{61}$ Ehrlich's opponents did not give his message a free pass outside Ottawa either. When a university economist lauded his work in a letter to the editor of the Globe and Mail, ${ }^{62}$ Robert Hann unleashed a rebuttal. ${ }^{63}$ So did sociologist David Chandler, who was happy to observe that, with Ehrlich having missed the boat, "[s]upporters of the death penalty must continue to search for a rational basis for the penalty.

Meanwhile, although all MPs had received a copy of Ehrlich's article, only a relatively few retentionists cited it in their parliamentary speeches. ${ }^{65}$ One of these few, MP Paul Dick, criticized the inclusion of pro-abolition sentiment and the absence of proretention claims in a certain government periodical. He cited Ehrlich's argument as an example of the retentionist perspectives not represented in the government message, a message which therefore failed to qualify as "a balanced view." But perhaps the lessthan-effusive wording Dick used in speaking of Ehrlich's article bore witness to the

\footnotetext{
${ }^{60}$ House of Commons Debates (3 May 1976), 13089 (Warren Allmand, MP - Liberal, NotreDame-de-Grâce, QC).

${ }^{61}$ See LAC, MG32, Series B35 (Walter Gilbert Dinsdale fonds), Volume 79, File 5 - File Title: "Capital Punishment. General. Feb.-July 1976," transcript of 25 May 1976 meeting for parliamentarians in Railway Committee Room with panel of speakers sponsored by Canadian Society for the Abolition of the Death Penalty, pp. 26-28 (speech by Harold Veal).

${ }^{62}$ Lloyd R. Cohen, letter to the editor, Globe and Mail, April 12, 1976, p. 6.

${ }^{63}$ Robert G. Hann, letter to the editor, Globe and Mail, April 19, 1976, p. 6.

64 David B. Chandler, letter to the editor, Globe and Mail, May 25, 1976, p. 7.

${ }^{65} \mathrm{I}$ am aware of six parliamentary speeches in which retentionist MPs cited Ehrlich's findings in a positive light. For evidence that each MP received a copy of the article, see LAC, MG32, Series B27 (Marcel Lambert fonds), Volume 81, File 14 - File Title: "Capital Punishment, 1976 file 2," John Reynolds to All Members of Parliament and Senators (a date stamp for September 9, 1975 appears on this copy of the letter), with the article attached. Interestingly, the words "DO NOT USE!" are written in pen on this particular copy of the Reynolds letter. While it is not clear why this comment was added (presumably by Lambert or one of his staffers), it would not be surprising if Lambert had become aware of the faults abolitionists had found with the article and if he had therefore decided that it would be unwise to cite it in debate.
} 
effectiveness of abolitionists' attack upon it: "Although this article has been challenged by a number of abolitionists and others who deal with statistics, and indeed has been found to be statistically complicated, it nevertheless happens to be a view."166 Ehrlich's ideas would not actually end up completely losing influence so quickly as it might have looked; it appears, for instance, that some Canadian retentionists sought to champion them during the mid-1980s debate over capital punishment as well. ${ }^{67}$ In 1976 , however, abolitionists seem to have squelched most of whatever confidence parliamentary retentionists might have initially felt concerning the article.

Thus, although retentionist claims about deterrence appeared on more than one occasion in the 1970s to be on the cusp of gaining greatly enhanced statistical credibility, abolitionists ended up getting the better of the fight over the quantitative interpretation of murder data. But if the confidence that Fattah's report helped to create in the abolitionist camp in 1973 remained intact in the 1976 debate, traces of the report's other contribution persisted as well. Back in November 1972, the Globe and Mail had commented upon a sort of "mass psychology" present in Canada involving a readiness "to accept without too much questioning that crime is edging out of control." To the editorialist, the attitudinal

\footnotetext{
${ }^{66}$ House of Commons Debates (7 June 1976), 14214 (Paul Dick, MP - Progressive Conservative, Lanark-Renfrew-Carleton, ON). Perhaps retentionists' lack of enthusiasm for Ehrlich's piece is not surprising in light of some of the particular blots on its reputation. Some critics suggested that "an algebraic error" had compromised Ehrlich's analysis. Deprived of this blemish, his puzzle pieces would reputedly have fit together differently, and his implied historical narrative would have rewritten itself, becoming a tale wherein, statistically speaking, American authorities who chose to have a given murderer put to death would not thereby have spared six citizens from suffering murder at some subsequent point in history, but would rather have cursed the country with fourteen additional killings that would now occur at some point ahead. See Robert G. Hann, letter to the editor, Globe and Mail, April 19, 1976, p. 6; House of Commons Debates (3 May 1976), 13089 (Warren Allmand, MP - Liberal, Notre-Dame-de-Grâce, QC). See also Hann, Critical Review of the Research of 1saac Ehrlich, I. page 16, VI. page 23. I do not know whether or not this point of critique proved to have merit.

${ }^{67}$ See Arron, "Punishment and Civilization," 47.
} 
terrain looked disturbingly hospitable for proponents of the death penalty. ${ }^{68}$ Especially by the 1976 debate, some abolitionists in Parliament were ready to push back against this sort of "mass psychology." MP Norman Cafik did so strongly in a speech in early May. In Cafik's view, Canadian eyes and ears locked onto television images and news accounts too much and lingered upon the flesh-and-blood world too little, leaving Canadian minds attached to the notion "that we live in a volatile, violent, and highly dangerous society," despite the happy scarcity of such characteristics in actual Canadian life. ${ }^{69}$ Several other abolitionists subsequently argued along similar lines. ${ }^{70}$ However, those listening to Cafik's speech also heard a good deal of detail concerning "the hard facts relating to crime in our society," with a number of the "hard statistics" in question possibly coming from Fattah's report. In some respects Cafik attempted to de-emphasize the unpleasant aspects of the story that this data told. But he still noted that "criminal homicide ... is the area where there is the least growth in violence," and the data made it seem reasonable to declare that "[i]f the public wants more peace and security then clearly we as legislators must deal not only with the question of capital punishment and how to deal with murderers but the larger and ever increasing problem of other forms of violent criminal activity." ${ }^{71}$

\footnotetext{
${ }^{68}$ See editorial, "Statistics Prove Nothing about Capital Punishment," Globe and Mail, November 30,1972, p. 6.

${ }^{69}$ House of Commons Debates (3 May 1976), 13100, and (5 May 1976), 13206 (Norman Cafik, MP - Liberal, Ontario, ON). The quotation is from p. 13206.

${ }^{70}$ See House of Commons Debates (5 May 1976), 13209-13210 (David MacDonald, MP Progressive Conservative, Egmont, PEI); (25 May 1976), 13819 (Stuart Leggatt, MP - NDP, New Westminster, BC); (26 May 1976), 13866 (Ross Milne, MP - Liberal, Peel-Dufferin-Simcoe, ON); (4 June 1976), 14180 (Derek Blackburn, MP - NDP, Brant, ON).

${ }^{71}$ House of Commons Debates (5 May 1976), 13206-13207 (Norman Cafik, MP - Liberal, Ontario, ON). Although Cafik did not indicate that he had drawn any of his crime data from Fattah's report, compare with Fattah, Study of the Deterrent Effect, 91, 93, 94, where a good bit of the same data is found.
} 
Such words were reminiscent of a statement in Warren Allmand's speech just two days before. Allmand asserted "that the real problem we must deal with is not simply one of murder here in Canada but that of crime throughout the western world." He had no intention of "sloughing off responsibility or minimizing the horror of murder," but "a simple concentration on capital punishment and murder takes much too restricted a view of the questions about which Canadians are concerned."72 And these statements were not so very different from the rather more striking phrasing used by abolitionist MP Gilles Marceau a few weeks later. In Marceau's view, murder lists might have been lengthening of late, but descriptions of this development sometimes exuded excessive pessimism and strayed from accuracy. "What has gone up, though," he noted,

is the number of criminal offences, and an important distinction must be made. Aggravated thefts, assaults and attempted assaults have increased. This indicates, Mr. Speaker, that violence is on the increase in our society, all forms of violence, verbal violence, written violence, violence in families, in society everywhere. This is where the real problem is. This violence, which we foster about everywhere, leads to murder. But when we want to control murder, we do not come to grips with the root of the problem but only with its head. ${ }^{73}$

Although Marceau seemingly wanted his colleagues to pay heed to violence in general rather than only to crime, his description of the potency of current violence probably resonated with those who tended to dwell upon the criminal version of that phenomenon.

Two of the other abolitionists who made the same type of point as Cafik about TV and (as he put it) the "disproportionate impression of a violent world" (House of Commons Debates [5 May 1976], 13206) nevertheless did make comments recognizing that, as Derek Blackburn put it, "crimes of all kinds are on the increase" - see House of Commons Debates (4 June 1976), 14180 (Derek Blackburn, MP - NDP, Brant, ON); (25 May 1976), 13820 (Stuart Leggatt, MP - NDP, New Westminster, BC).

${ }^{72}$ House of Commons Debates (3 May 1976), 13088 (Warren Allmand, MP - Liberal, NotreDame-de-Grâce, QC).

${ }^{73}$ House of Commons Debates (28 May 1976), 13948 (Gilles Marceau, MP - Liberal, Lapointe, QC). 
Abolitionists did put up a modest fight against the "mass psychology" about which the

Globe had worried. But in the end, their claims about deterrence and crime could find a

little more common ground with that mass psychology than might have been anticipated.

\section{Rhetorical Interpretations of Crime: Permissiveness in Three Flavours}

According to Fattah's report, "the cause of homicide and murder cannot be found in any single factor but in a total social situation in which a special law or a particular punishment can have little or no effect." Warren Allmand took a liking to this statement, working it into speeches to the House of Commons in both 1973 and $1976 .^{74}$ Many retentionists may not have bought into Fattah and Allmand's skepticism about penal deterrence, and retentionists may have failed to consider many facets of the "total social situation" in Canada, but they were happy to discuss more than merely the death penalty and murder sentences when examining the topic of Canadian homicide. Moreover, since even some abolitionist speeches were noting "the obvious increase in the crime rate as a whole," 75 retentionists in the 1970 s were in good position to argue that the nation's present "social situation" included not just a few imperfections, but some type of serious malignancy. MPs who attempted to identify the nature of that malignancy did not reach unanimous agreement, ${ }^{76}$ but a certain word did become especially popular in their

\footnotetext{
${ }^{74}$ Fattah, Study of the Deterrent Effect, 193; House of Commons Debates (26 January 1973), 690 (Warten Allmand, MP - Liberal, Notre-Dame-de-Grâce, QC); (3 May 1976), 13089 (Warren Allmand, MP). In the 1973 speech, Allmand offered the statement as part of a quotation from Fattah; in 1976 Allmand repeated it nearly verbatim in a discussion of Fattah's arguments.

${ }^{75}$ House of Commons Debates (22 May 1973), 3984 (Derek Blackburn, MP - NDP, Brant, ON).

${ }^{76}$ For an abolitionist speech using this image of a "malady," "a sickness in our society which has to be diagnosed," see House of Commons Debates (29 May 1973), 4226 (Gerald Baldwin, MP - Progressive Conservative, Peace River, AB).
} 
discussion. The House of Commons began to hear a great deal about "permissiveness."

During the 1960 s, at least some Canadians had considered "permissive" to be an apt adjective for the then-current ethos of the nation. ${ }^{77}$ However, in the 1970 s the term began to recur frequently in the parliamentary debate on the death penalty. Over fifty of the speeches dealing with capital punishment mentioned "permissiveness" or "permissive" aspects of current Canadian life, usually in tones of disapproval. References to permissiveness occasionally punctuated the debate outside Ottawa as well. ${ }^{78}$ And there was enough interest in denigrating the phenomenon for Ontario premier Bill Davis to decide in 1975 to portray himself as an active opponent of the trend that threatened to make the province "too permissive." permissiveness gained its greatest momentum in Parliament. Such discussion became a significant, if not overpowering, feature of MPs' death-penalty rhetoric, with different MPs incorporating criticism of permissiveness into slightly different diagnoses of the nation's current troubles. ${ }^{80}$

${ }^{77}$ See B. Wojciechowski, letter to the editor, Globe and Mail, April 12, 1966, p. 6; see House of Commons Debates (22 November 1967), 4577 (Heath Macquarrie, MP - Progressive Conservative, Queens, PEI); see also the discussion in LAC, RG36, Series 24 (Canadian Committee on Corrections sousfonds), Volume 20, File Title: "Spare Copies - 'Talks' by Professor Desmond Morton," Talk Number One, p. 1, Talk Number 2, p. 1, and Talk Number 3, p. 4. Morton himself seemed skeptical about the accuracy of "permissive" as a descriptor.

${ }^{78}$ See, for example, Richard M. Haney, letter to the editor, Toronto Star, December 30, 1971, p. 7; Syd Brown, President, Canadian Police Association, letter to the editor, Toronto Star, October 30, 1972, p. 7; Mrs. W.H. Shaw, letter to the editor, Toronto Star, January 23, 1975, p. C5; Wayne Seymour, letter to the editor, Toronto Star, September 19, 1975, p. B5.

B3.

${ }^{79}$ Quoted in Rex MacLeod, "What's Permissiveness? A Puzzle," Toronto Star, April 25, 1975, p. 
Permissiveness as Moral Decay

Socially conservative MPs found that the term "permissiveness" could help them describe the bad habits that they believed the nation had established in its approach to making both concrete choices and theoretical judgments concerning morality.

Dissatisfaction on this front was not unique to the 1970s; some retentionists had been quite ready in the earlier years of the debate to allege that Canada was flirting with the urge to mangle morality. "The main arguments of abolitionists," charged one MP vehemently in 1966 ,

are based on emotionalism, sophism, the weakening of the authority required to maintain order, the contradiction of God's commandments, materialism and more often than not, atheism. They are based on a distorted psychology tending to abolish the notion of sin, of personal responsibility, and to find society guilty of all sins and crimes of individuals considered as victims of that society. And since criminals, through this reasoning, become the victims of society, it is felt that those poor victims must be spared, looked after, coddled and even pampered. Is this not topsy-turvydom, the negation of divine rights and authority, of the rights of society to punish evil and protect us from it? ? $^{81}$

After 1970, certain retentionists who felt bothered by such "topsy-turvydom"

found it useful to invoke the buzzword "permissive" when critiquing present mentalities. To a number of MPs, contemporary moral vertigo took tangible form in another specific controversy of the day - abortion. "[T]he permissive legislation of recent years has reflected the moral decline of society," alleged Walter Dinsdale. He pointed out as well that "[o]n the one hand we defend the right of the psychopathic criminal to life, and on the other hand we deny the right to life to the innocents who are now being eliminated by

\footnotetext{
${ }^{81}$ House of Commons Debates (5 April 1966), 3897 (Henri Latulippe, MP - Ralliement Créditiste, Compton-Frontenac, QC).
} 
the thousands in what, in effect, is abortion on demand." To Dinsdale, this combination of viewpoints added up to "moral confusion." ${ }^{82}$ Other MPs warned against more general incoherence in moral judgment. "Unless we realize there is such a thing as evil in society," declared one retentionist,

then we reach the peculiar situation in which we say that if a person is not to blame for his actions which are evil, we cannot praise someone for actions which are good. This, of course, is utter nonsense. The only way in which society can function is by having law and order based on a recognition of that which is wrong.

If society becomes too permissive, we then have a situation in which society is blamed for everything and in which no one takes responsibility for himself. ${ }^{83}$

MP Peter Masniuk made a related point. He noted the "more relaxed moral values and more and more permissive attitudes toward human behaviour" apparent in Canada of late, and he also observed regretfully that "[t]he concept of evil as an absolute has gone out of fashion, the same as has the concept of absolute virtue. There are no saints today, and there are no sinners either." ${ }^{\text {84 }}$ After reading a letter sent by the head of a United Church committee, Dinsdale composed a reply.

\footnotetext{
${ }^{82}$ House of Commons Debates (22 May 1973), 3987 (Walter Dinsdale, MP - Progressive Conservative, Brandon-Souris, MB). For other instances in which retentionist MPs criticized the reputed belief in abortion rights within much of the abolitionist camp, see, for example, House of Commons Debates (24 May 1973), 4079 (Gilbert Rondeau, MP - Social Credit, Shefford, QC); (24 May 1973), 4083 (Jake Epp, MP - Progressive Conservative, Provencher, MB); (15 June 1976), 14499 (J.A. MacLean, MP Progressive Conservative, Malpeque, PEI). For an abolitionist criticism of anti-abortion retentionists, see House of Commons Debates (29 January 1973), 728 (Peter Reilly, MP - Progressive Conservative, Ottawa West, ON). For an anti-abortion abolitionist stance, see, for example, House of Commons Debates (31 January 1973), 839 (John Reid, MP - Liberal, Kenora-Rainy River, ON). For an expression of support for the therapeutic abortion provisions of the day by a retentionist, see House of Commons Debates (14 May 1976), 13542 (Iona Campagnolo, MP - Liberal, Skeena, BC).

${ }^{83}$ House of Commons Debates (23 July 1973), 5882-5883 (Ian Arrol, MP - Progressive Conservative, York East, ON). See also House of Commons Debates (31 January 1973), 835 (Ian Arrol, MP).

${ }^{84}$ House of Commons Debates (11 May 1976), 13406 (Peter Masniuk, MP - Progressive Conservative, Portage, MB). For another retentionist's defence of "absolutes," see House of Commons Debates (8 June 1976), 14252-14255 (Benno Friesen, MP - Progressive Conservative, Surrey-White Rock, BC).
} 
I see that the United Church is still strongly supporting the complete abolition of capital punishment.... [I]t is difficult to understand the Church's position. After all the murderer who deliberately uses homicide as a part of his criminal activity ... is in a more favourable position for repentence [sic] even though he might be a psychopath. On the other hand the victim has no choice in the matter.

I guess it is just one of the strange perversions of our time when "evil is good and good is evil." $" 85$

At least some social conservatives saw permissiveness not merely as a theoretically befuddling or philosophically annoying mentality, but as a phenomenon that could buoy up citizens' interest and success in establishing criminal habits or adopting disreputable practices. One MP argued that "one does not turn into a murderer overnight. No, Mr. Speaker, this is caused by our society which advocates permissiveness, and laisser [sic] faire." Retentionist Alex Patterson observed that "[w]e have been living in a period of permissiveness in society which has shown itself not only in juvenile delinquency but in the lack of ethical conduct on the part of government." Quoting an excerpt from the Ottawa Journal, he highlighted the lawbreaking, substance abuse, or prostitution in which many were now dabbling or drowning during their teenage years. Still, his assessment of society's current quandary dealt with more than just these specific types of frowned-upon activity:

[I] $\mathrm{n}$ trading off moral and spiritual values for the seeming benefits of crass materialism and secularism, successive generations are providing the climate in which selfishness, disrespect for the rights of others, and naked violence find ready expression. Spiritual laws have been repudiated, the old-fashioned virtues

\footnotetext{
${ }^{85}$ LAC, MG32, Series B35 (Walter Gilbert Dinsdale fonds), Volume 79, File 5 - File Title: "Capital Punishment. General. Feb.-July 1976," Walter Dinsdale to Reverend William F. Phipps, Chairman, Penal Reform Task Force, The United Church of Canada, June 3, 1976; see also William F. Phipps, Chairman, Penal Reform Task Force, The United Church of Canada, to Warren Allmand, Solicitor General, and Ronald Basford, Minister of Justice (cc'd to “Members of Parliament"), May 18, 1976.

${ }^{86}$ House of Commons Debates (11 May 1976), 13420 (Eudore Allard, MP - Social Credit, Rimouski, QC).
} 
have been replaced by the so-called new morality, and situation ethics have taken the place of the principle of right and wrong.

In the eyes of MPs like Patterson, Canadian moral life was turning rancid, and the stink of crime and homicide accompanied that more general tragedy. ${ }^{87}$

The situation amounted to a tragedy partly because of the greatness of the morality that now seemed to be growing faint in the Canadian vision. Peter Masniuk suggested that, in addition to looking askance at "moral absolutes," Canadian opinion leaders were becoming unwisely contemptuous toward "the ancients": "What the ancient societies knew and accepted, today we doubt and deny, and in so doing we have abdicated justice." Moreover, the elites of society appeared inclined to forget or ignore divine wisdom on the issue. Masniuk offered biblical passages that seemed to reveal the validity of the retributive dynamics of justice — dynamics that aligned, he believed, with "God's law." Another MP also saw a pro-capital-punishment message in certain scriptural excerpts, which expressed "the wish of God, who is the divine ruler of the world." expected to discover the optimal approach to the death-penalty controversy and associated moral issues by identifying God's perspective, failure to perceive or buy into that perspective would be a serious loss for all concerned.

\footnotetext{
${ }^{87}$ House of Commons Debates (14 May 1976), 13538 (Alex Patterson, MP - Progressive Conservative, Fraser Valley East, BC). For the article that he quoted, see Ian Haysom, "Delinquency Casebooks: 'Sick' Facts," Ottawa Journal, April 10, 1976, pp. 1-2.

${ }^{88}$ House of Commons Debates (11 May 1976), 13405-13408 (Peter Masniuk, MP - Progressive Conservative, Portage, MB).

${ }^{89}$ House of Commons Debates (10 June 1976), 14353 (William Skoreyko, MP - Progressive Conservative, Edmonton East, $\mathrm{AB}$ ).
} 
Permissiveness and Violence

We might consider it entirely predictable that socially conservative retentionists would talk about permissiveness. Perhaps better evidence of the term's currency in the early 1970s is its appearance in a number of abolitionist speeches in the House of Commons. ${ }^{90}$ Although the concept contributed less to their rhetoric than to that of the retentionists, in a few cases abolitionists spoke of permissiveness in nearly the same breath as one of their favourite targets of criticism - violence. One abolitionist noted that "there has been a growth in what is called permissiveness which has been tied to the growth of violence in our society." Admittedly, it is not clear whether this speaker was himself lumping permissiveness and violence together or whether he was merely indicating that other observers did so. ${ }^{91}$ But the two terms cropped up together in another abolitionist speech as well, as MP Gerald Baldwin suggested that some degree of correlation existed between "the tremendous acceleration toward urbanization" and "the rise of permissiveness, militancy, violence, changes in life style, increased use of drugs, and the thrust of organized crime." 92 The two concepts had brushed together in abolitionist rhetoric on yet another occasion two weeks earlier. "Someone in this House stated today that we have a permissive society," declared one MP to his fellows. "This is so because of permissive parents and permissive institutions. We live in an age of violence." He immediately began to speak of a particularly dirty junior hockey match that

\footnotetext{
${ }^{90}$ At least thirteen abolitionist speeches in the 1970 s contained the term "permissive" or "permissiveness."

${ }^{91}$ See House of Commons Debates (31 January 1973), 837 (John Reid, MP - Liberal, KenoraRainy River, ON).

${ }^{92}$ House of Commons Debates (29 May 1973), 4226 (Gerald Baldwin, MP - Progressive Conservative, Peace River, AB).
} 
had left a certain competitor "severely maimed." 93 While abolitionists did not frequently move from discussion of permissiveness to contemplation of hockey, they did speak often about violence, and it is no surprise that this central theme in their speeches would overlap at times with the now-popular topic of permissiveness.

To abolitionists, many of the central shortcomings of early-1970s Canada pertaining to the death-penalty controversy could be articulated by invoking the word "violence." As one abolitionist MP put it, "We are living in a sick, violent society." The violence in which abolitionists perceived danger included more types of activity than just violent crime. If most abolitionists did not take aim at the brutality on the ice rink, ${ }^{95}$ quite a few did express displeasure about the persistent penchant for violence that flavoured the shows and news dominating the tube. One abolitionist worried about those children and adults who watch the media and listen to the hotliners, because in my opinion the spreading abroad of the details of these horrible, heinous and gory crimes, which we have witnessed in this country during the last few months, has done nothing to contribute to keeping down the climate of violence which is escalating in so frightening a manner these days. ${ }^{96}$

\footnotetext{
${ }^{93}$ House of Commons Debates (14 May 1973), 3724 (Elias Nesdoly, MP - NDP, Meadow Lake, SK).

${ }^{94}$ House of Commons Debates (10 May 1976), 13371 (Lincoln Alexander, MP - Progressive Conservative, Hamilton West, ON).

${ }^{95}$ For an abolitionist speech that does deal with violence in hockey, see House of Commons Debates (19 October 1973), 7059 (Peter Reilly, MP - Progressive Conservative, Ottawa West, ON).

${ }^{96}$ House of Commons Debates (15 May 1973), 3763 (Grace MacInnis, MP - NDP, Vancouver Kingsway, BC). For some of the other abolitionist references to TV violence, see House of Commons Debates (29 January 1973), 753 (Maurice Foster, MP - Liberal, Algoma, ON); (24 July 1973), 5923 (Gerald Baldwin, MP - Progressive Conservative, Peace River, AB); (19 October 1973), 7059 (Peter Reilly, MP - Progressive Conservative, Ottawa West, ON); (22 October 1973), 7074 (Eymard Corbin, MP - Liberal, Madawaska-Victoria, NB); (5 May 1976), 13221 (Ursula Appolloni, MP - Liberal, York South, ON); (25 May 1976), 13819-13820 (Stuart Leggatt, MP - NDP, New Westminster, BC); (26 May 1976), 13871 (Howard Johnston, MP - Progressive Conservative, Okanagan-Kootenay, BC). Some retentionists discussed TV violence as well - for just two examples, see House of Commons Debates (10 May 1976), 13355-13357 (Arnold Malone, MP - Progressive Conservative, Battle River, AB); (8 July 1976), 15175 (Adrien Lambert, MP - Social Credit, Bellechasse, QC).
} 
The suspicion that television audiences might overdose on such contemplation of injury and death was not just an artificial fear conjured up solely for rhetorical purposes in the capital-punishment debate. Rather, it appears to have been a relatively familiar, though certainly contested, notion in the public arena at the time. For instance, in 1975 the issue gave Judy LaMarsh, who in the 1960s had held cabinet portfolios in Lester Pearson's government, the chance to don the hat of royal commissioner at the behest of the Ontario government, which purportedly wished to gain some wisdom concerning the TV-violence quandary. ${ }^{97}$ In any case, seeing that a portion of the populace had apparently been cultivating stronger habits of illegal violence, abolitionists found themselves readier to imagine that even violent thought and conduct not prohibited by law might be changing Canadians in ways more detrimental than had been expected.

To abolitionists, hostility to violence fit perfectly with hostility to the death penalty. Terminating a convict's life, said one abolitionist, "is in effect a collective act of violence. By such an act society condones violence and by condoning encourages it." ${ }^{\text {"98 }}$ MP Derek Blackburn repeated a theme that had certainly been heard before in the debate: "violence begets violence."99 Such statements could certainly encourage the cultivation

\footnotetext{
${ }^{97}$ See Toronto Star, "Probe May Persuade Advertisers to Drop Violent Shows - LaMarsh," April 15, 1975, p. A4; Toronto Star, “TV Violence Probe Is Called a 'Stunt,"” April 15, 1975, p. A4; Toronto Star, "Ontario Takes Aim at Televiolence of 'Sick Minds, Greedy Networks,"” April 15, 1975, p. B3; Rex MacLeod, "Does TV Violence Spawn the Real Thing? Nobody Really Knows," Toronto Star, April 16, 1975, p. B3; Jim Paine, letter to the editor, Toronto Star, May 12, 1975, p. C5; Fred and Barbara Clarke, letter to the editor, Toronto Star, May 12, 1975, p. C5.

${ }^{98}$ House of Commons Debates (8 June 1976), 14248 (J.-J. Blais, MP - Liberal, Nipissing, ON). Along related lines, see House of Commons Debates (3 May 1976), 13090 (Warren Allmand, MP - Liberal, Notre-Dame-de-Grâce, QC); (5 May 1976), 13220-13221 (Ursula Appolloni, MP - Liberal, York South, ON); (15 June 1976), 14501 (Pierre Trudeau).

${ }^{99}$ House of Commons Debates (4 June 1976), 14178 (Derek Blackburn, MP - NDP, Brant, ON). For similar statements, see House of Commons Debates (24 July 1973), 5924 (Gerald Baldwin, MP Progressive Conservative, Peace River, AB); (24 July 1973), 5949 (Ed Broadbent, MP - NDP, Oshawa-
} 
of an instrumentalist mind-set with respect to the death-penalty issue, since they suggested by implication that any citizens who wished to see some of the current violent crime evaporate should view abolition as a useful component in an anti-violence strategy, even if such citizens felt no urgent abolitionist conviction when examining the controversy philosophically ${ }^{100}$ But for at least some abolitionists, violence directly triggered ethical unease - even violence of a lawful variety. MP Doug Roche expressed many abolitionists' point of view when he noted that "[w]e are allowed to kill in selfdefence, as we know, but for the state to execute a criminal is to perpetuate violence. I believe," he added, "in a morality which excludes violence as permissible conduct."101 Many abolitionists might have added a few qualifications to the last part of the statement, but it captured what was probably the general ethos preferred by a good number of citizens in the abolitionist camp. ${ }^{102}$

Ruminations on violence, reminders of instrumental possibilities, and nudges toward moral vision mingled together in the Catholic bishops' input to the debate in the 1970s. During the 1960s, Canadians looking for explicit encouragement to work for

Whitby, ON); David M. Blackwell, letter to the editor, Toronto Star, February 25, 1975, p. B5; LAC, MG32, Series B35 (Walter Gilbert Dinsdale fonds), Volume 79, File 5 - File Title: "Capital Punishment. General, Feb.-July 1976," Canadian Catholic Conference, "Catholic Bishops Want Capital Punishment Abolished," news release, February 27, 1976. Fort William, ON).

${ }^{100}$ See especially House of Commons Debates (9 April 1976), 12685 (Paul McRae, MP - Liberal,

${ }^{101}$ House of Commons Debates (22 May 1973), 3977 (Douglas Roche, MP - Progressive Conservative, Edmonton-Strathcona, AB). Unlike in 1973, in the 1976 debate Roche refused to vote for the abolitionist legislation. However, he claimed to want to see the nation turn abolitionist in the not-toodistant future, and he repeated that "I believe in a morality which excludes violence as permissible conduct" - see House of Commons Debates (5 May 1976), 13219-13220 (Douglas Roche, MP - Progressive Conservative, Edmonton-Strathcona, $\mathrm{AB}$ ).

${ }^{102}$ For the views of one abolitionist to whom this statement does not seem to apply, see House of Commons Debates (9 July 1976), 15224 (Arnold Peters, MP - NDP, Timiskaming, ON). 
abolition would not have found any among the viewpoints that the bishops as a group saw fit to present to the public. ${ }^{103}$ In 1973, however, a document from the Canadian Catholic Conference (CCC) gave MPs the chance to hear the bishops' current recommendations, which generally promoted an abolitionist mentality. "The question of the death penalty, in our opinion, ought not [to] focus on whether a convicted murderer, no matter how wanton, 'deserves' to die," the CCC suggested. "The focus should be on us: should Canadians as a community try to break the escalating spiral of violence by refraining from violence even as a deterrent?"104 A CCC discussion of the topic in February 1976 confirmed the bishops' willingness to speak in firmly (if not unbudgingly) abolitionist phrases. ${ }^{105}$ So did a speech to MPs by the CCC head, Bishop Emmett Carter, three months later. Carter noted "the escalation of violence" that "is anything but a passing phase." But in his judgment, Canadians could start to turn this escalation into a decrescendo through abolition, which would amount to "an attempt at reconciliation, an attempt to exercise self-restraint, an attempt to show the way to higher and better

\footnotetext{
${ }^{103}$ See Melton, The Churches Speak on: Capital Punishment, 1-3.

${ }^{104}$ LAC, MG32, Series B35 (Walter Gilbert Dinsdale fonds), Volume 79, File 2 - File Title: "Capital Punishment. General 1973," The Administrative Board of the Canadian Catholic Conference and W.E. Power, President, to Hon. Members of the Senate and the House of Commons, January 26, 1973; see also Melton, The Churches Speak on: Capital Punishment, 3. The statement I have quoted here was also quoted or paraphrased more than once in the House of Commons - see House of Commons Debates (30 January 1973), 781 (David MacDonald, MP - Progressive Conservative, Egmont, PEI); (15 May 1973), 3763 (Grace MacInnis, MP - NDP, Vancouver Kingsway, BC); (25 May 1976), 13805 (Joe Flynn, MP Liberal, Kitchener, ON).

${ }^{105}$ See LAC, MG32, Series B35 (Walter Gilbert Dinsdale fonds), Volume 79, File 5 - File Title: “Capital Punishment. General, Feb.-July 1976," Canadian Catholic Conference, "Catholic Bishops Want Capital Punishment Abolished," news release, February 27, 1976. Although the title of this news release expresses the main point conveyed by the release itself, it should be noted that the release also quoted Bishop G. Emmett Carter, CCC head, as follows: "The bishops wished to make clear the position of their national association, but, in taking their position, they recognize the right of the state to impose capital punishment if the circumstances demand it, and they acknowledge that Christians may hold individual opinions on the subject."
} 
things." ${ }^{106}$ In their discussion of violence, Carter and the CCC employed familiar themes from a principal abolitionist interpretation of current Canadian struggles, while simultaneously using language that at times aligned closely with the abolitionist ethical outlook discussed in Chapter 3.

\section{Permissiveness in Criminal Justice}

Despite the various examples given in the preceding pages, the term "permissiveness" often reminded both retentionists and abolitionists not so much of moral putrefaction writ large or of violence in general, but rather of the recent outlook and decision-making of criminal-justice authorities. One suspects that historians could identify several particularly gut-wrenching murders in any given half-decade of Canadian history. It also seems likely that most periods have witnessed spectacular crimes that materialized out of circumstances created partly by poor judgment on the part of criminaljustice officials. In any case, however, Canadians certainly did not miss out on either of these types of tragedy in the first half of the 1970s. Whether or not citizens actually had to suffer more than the normal number of such incidents during this period, many felt that officials had dished up an extra large helping of penal debacles for the country.

As a result of the authorities' desire that the correctional system walk its rehabilitative talk, many incarcerated convicts got to spend some time walking, living, and sleeping on

\footnotetext{
${ }^{106}$ See LAC, MG32, Series B35 (Walter Gilbert Dinsdale fonds), Volume 79, File 5 - File Title: "Capital Punishment. General. Feb.-July 1976," transcript of 25 May 1976 meeting for parliamentarians in Railway Committee Room with panel of speakers sponsored by Canadian Society for the Abolition of the Death Penalty, pp. 13-18 (the quotes are from pages 15-16) (speech by Bishop Emmett Carter), attached to Memorandum from Ged Baldwin, Stanley Knowles, and Jim Fleming to All Members of Parliament and Senators, June 8, 1976.
} 
other portions of Canadian soil than that contained within penitentiary compounds sometimes thanks to parole, but sometimes thanks to the temporary absence program, as it was known. These lungfuls of freedom might have set the wheels turning in the minds of a few convicts who liked the thought of playing thief or assailant once more, or of dropping out of sight in order to kiss a permanent goodbye to prison, but most convicts did not act on any such temptations. Occasionally, however, one did. ${ }^{107}$ A young girl's death in the Greater Vancouver area in June 1972 turned out to be the handiwork of Garry Head, a sex offender enjoying a few days of freedom provided through a legitimate permit to leave prison for a weekend. Worse, the deed reputedly amounted to his way of settling a score with the girl's father, who numbered among the guards staffing a prison in which Head had formerly resided. ${ }^{108}$

Although this was not the only occasion in 1972 on which the public had specific cause to regret the short period of freedom provided to a particular convict, ${ }^{109}$ public anger toward the federal authorities probably did spike most sharply in this instance. At a

${ }^{107}$ See House of Commons Debates (21 February 1972), $50-53$ (Jean-Pierre Goyer, MP - Liberal, Dollard, QC); (1 June 1973), $4332-4334$ (Warren Allmand, MP - Liberal, Notre-Dame-de-Grâce, QC); see also Clair Balfour, "Sex Offender Out on Pass Charged As Slayer of Girl," Globe and Mail, metro edition, June 28, 1972, p. 1.

${ }^{108}$ See Clair Balfour, "Sex Offender Out on Pass Charged As Slayer of Girl," Globe and Mail, metro edition, June 28, 1972, p. 1; John Slinger, "Head's Murder Confession Concocted, B.C. Editor Quotes Convict As Admitting," Globe and Mail, January 26, 1973, metro edition, pp. 1-2; John Slinger, "Parents of Murdered Girl Call for Death Penalty," Globe and Mail, January 27, 1973, metro edition, p. 1; Staff, "Head Is Sentenced to Another Life Term," Globe and Mail, January 27, 1973, metro edition, pp. 12; see Allan Fotheringham, "Prison Policy Hurt the Liberals in B.C.," Toronto Star, January 31, 1973, p. 8.

${ }^{109}$ For brief information on the then-well-known affair involving murderer Yves Geoffroy, whose temporary absence in late December 1971 stretched on for three months in controversial circumstances, see Clair Balfour, "Sex Offender Out on Pass Charged As Slayer of Girl," Globe and Mail, metro edition, June 28, 1972, p. 1 (note that Geoffroy was not the "[s] ex [o]ffender" referred to in the headline); see also House of Commons Debates (6 July 1976), 15107-15108. For another case, see Allan Fotheringham, "Prison Policy Hurt the Liberals in B.C.," Toronto Star, January 31, 1973, p. 8. 
certain point in June 1972, it seemed to one Liberal in BC that "[t]he mood in this town at the moment is such that if [Solicitor General] Jean-Pierre Goyer came here this week there'd be a lynch mob out." ${ }^{110}$ According to columnist Allan Fotheringham, British Columbians' displeasure concerning the Head affair and related penal issues could be considered a "substantial part" of the reason why the federal Liberals lost power in eleven BC ridings in the October 1972 election. ${ }^{111}$ As Fotheringham also noted, many citizens perceived the Head incident as another reason to resent authorities' parole policies, since many people remained unaware that Head's weekend in the wide world had resulted not from parole, but from temporary-absence policies. ${ }^{112}$

But if the word "parole" irritated many of the citizens who felt peeved by the penal system, "bail" could rankle as well. In January and early February of 1973, two Toronto police officers bit the dust in murderous encounters with men who were already destined for court for alleged crimes but had been able to enjoy freedom in the meantime — in the one case, by virtue of having posted bail, but in the other case, by virtue of related provisions under which the man in question had not actually had to cough up any bail money. These latter provisions reflected not traditional bail regulations, but rather a modified framework instituted in 1972. Needless to say, such news produced few positive feelings about the authorities' perspective on how to identify worthy candidates

\footnotetext{
${ }^{110}$ Quoted in Allan Fotheringham, "'Prison Policy Hurt the Liberals in B.C.," Toronto Star, January $31,1973, \mathrm{p} .8$. Fotheringham did not name the individual being quoted.

${ }^{111}$ Allan Fotheringham, "Prison Policy Hurt the Liberals in B.C.," Toronto Star, January 31, 1973, p. 8. See also Jes Odam, "Tories 109 - Liberals 108," Vancouver Sun, October 31, 1972, p. 1-2.

${ }^{112}$ See Allan Fotheringham, "Prison Policy Hurt the Liberals in B.C.," Toronto Star, January 31, 1973, p. 8; see also Clair Balfour, "Sex Offender Out on Pass Charged As Slayer of Girl," Globe and Mail, metro edition, June 28, 1972, p. 1; see also House of Commons Debates (31 January 1973), 846 (Len Marchand, MP - Liberal, Kamloops-Cariboo, BC).
} 
for bail, or for other forms of exemption from pre-trial incarceration. ${ }^{113}$

Further annoyance resulted from the game of escape, in which Canadian convicts seemed to be wracking up a shining record of success. The correctional system had suffered the indignity of over three hundred escapes in 1972 - over seventy-five percent more than in 1970. On May 8, 1973, one MP drew Parliament's attention to the general trend. ${ }^{114}$ Five days later, five veterans of earlier escapes again proved their prowess in giving their correctional captors the slip, despite the purported maximum-security impediments that had been supposed to bar their way. And the fivesome included an offender with two murder victims to his name. Besides becoming a subject of discussion in its own right in the House of Commons, the affair occurred just a day before the 1973 capital-punishment legislation, which MPs had discussed only a little in the House since February, became a chief topic of active parliamentary debate once more. ${ }^{115}$

Given events of this nature, some MPs debating the death penalty perceived "permissiveness" as an apt term to use when discussing policies and judgments pertaining

${ }^{113}$ See Toronto Star, "Girl of 17 Is Accused of Policeman's Murder," January 12, 1973, four star edition, pp. 1, 4; see editorial, "Bail Reform Law Must Be Tightened," Toronto Star, January 16, 1973, p. 6; see editorial, "Speedy Trials Are the Real Answer," Toronto Star, February 5, 1973, p. 6. For letters to the editor expressing frustration concerning these murders and related bail issues, see L. Claire O'Brien, letter to the editor, Toronto Star, January 25, 1973, p. 7; R. McDonald, letter to the editor, Toronto Star, January 25, 1973, p. 7; W.J. Gaiger, letter to the editor, Toronto Star, February 8, 1973, p. 7; M.M. Morris, letter to the editor, Toronto Star, February 8, 1973, p. 7. A number of other letters decrying these two murders also appear in the Star, especially on January 25 and February 7-8.

${ }^{114}$ See House of Commons Debates (18 April 1973), 3422; (8 May 1973), 3538 (Robert Coates, MP - Progressive Conservative, Cumberland-Colchester North, NS); (18 July 1973), 5745 . The tally of escapes for 1972 rose to over 650 if the total was expanded to include the offenders whose day parole or allotted period of temporary absence expired without their having put themselves back in the hands of the correctional authorities as required.

${ }^{115}$ See United Press International-Canadian Press, "Double Murderer 4 Others Escape from Quebec Jail," Toronto Star, four star edition, May 14, 1973, p. 1; see House of Commons Debates (14 May 1973), 3693, 3707-3709, 3711, 3716. For Pierre Trudeau's reference to the affair in his speech on the death penalty, see House of Commons Debates (16 May 1973), 3843 (Pierre Trudeau). 
to incarceration and release, or when attacking criminal-justice authorities' outlook in general. One opposition MP speaking early in the 1973 debate suggested that certain "tragic events," including the Head affair and the demise of one of the Toronto policemen, revealed the faults "of the permissive direction which the government is taking with respect to parole practices, bail reform and the like." ${ }^{116}$ Another retentionist declared that his constituents "are not against rehabilitation, do not get them wrong. What they are against are consultants and do-gooders being hoodwinked by a bunch of smart con men into getting early paroles or leave passes on compassionate grounds."117 After discussing at length the allegedly easy-going atmosphere and non-demanding rules characterizing prison life, a retentionist speaking in the 1976 debate castigated "the permissiveness and liberalism that exists within the penitentiary service at this time."118 Some abolitionists also felt ready to reprimand criminal justice for its failings. John Diefenbaker seemed to think that the mercury in the crime thermometer was creeping a little too high on the scale. He trotted out the p-word: "Why is there this permissiveness? Is there any danger today for a person committing a crime in this country?" He noted that the parole board had gotten its start during his years in power. "But, Sir," he declared, "the parole board ought not to be a freedom board for individuals who have been convicted of serious offences." ${ }^{119}$ Some fellow abolitionists sang a similar

\footnotetext{
${ }^{116}$ House of Commons Debates (26 January 1973), 697 (Erik Nielsen, MP - Progressive Conservative, Yukon, YT).

${ }^{117}$ House of Commons Debates (30 January 1973), 808 (Donald Munro, MP - Progressive Conservative, Esquimalt-Saanich, BC).

${ }^{118}$ House of Commons Debates (17 June 1976), 14597 (see also 14596) (Robert C. Coates, MP Progressive Conservative, Cumberland-Colchester North, NS).

${ }^{119}$ House of Commons Debates (30 January 1973), 786 (John Diefenbaker, MP - Progressive Conservative, Prince Albert, SK).
} 
tune regarding parole, referring to "these ridiculous, easy paroles"120 and "the abject failure of the parole board." 121

Speaking about parole-related quandaries in the penal system allowed abolitionists to agree with many citizens that messes existed and should be cleaned up, but still to portray the effects of abolition as fully benign. In contrast, although many retentionists believed that society could eliminate significant infections in its crime-related wounds by combating deficiencies in parole, the temporary-absence framework, and other specific facets of criminal justice, they did not consider this to mean that no important component of the treatment for those wounds could be found through the capital-punishment tradition. If the arguments of Fattah and others had taken the statistical wind out of retentionists' sails, the latter group could still find other ways to reaffirm their vision of a death penalty that could claim practical merit. Retentionists might have captured much more rhetorical ground had their claims about deterrence contained a persuasive statistical component, but as Stuart Banner observes of the American scene, one important rejuvenating force kept the retentionist perspective on deterrence alive and relatively well — the highly resilient assumptions of "folk wisdom." 122 One letter writer commenting upon the death penalty illustrated this phenomenon through the type of simple observation that is worthy of historical notice: "most people feel this [capital punishment] ${ }^{2}$ Lambton, ON). Rainy River, ON). For a less strongly worded abolitionist critique of authorities' handling of parole, see House of Commons Debates (31 January 1973), 846 (Len Marchand, MP - Liberal, Kamloops-Cariboo, $\mathrm{BC})$.

\footnotetext{
${ }^{122}$ Banner, Death Penalty: An American History, 281.
} 
is a deterrent regardless of all statistics quoted." ${ }^{123}$

Moreover, retentionists could also craft claims that possessed a pragmatic sound but remained outside the framework of deterrence. One MP explained that "[e]ven if capital punishment does not act as a general deterrent, capital punishment certainly prevents the person who kills from ever murdering again."124 A letter to the editor in the Toronto Star made the same main point, even though it used the terminology of deterrence: "As for those who claim that capital punishment is no deterrent, I claim otherwise. Those who are executed for murder will be most effectively deterred from ever committing murder a second time."125 "The Canadian public," argued another retentionist letter,

does not care if capital punishment is a deterrent or not. Their overwhelming concern is their own and their families' security. Sending a murderer to prison does not give the public a guarantee that he will never be able to reenact his hideous deeds against society. ${ }^{126}$

Such retentionists believed that those who wished to see a given murderer become fully incapacitated would find that an executioner and a coffin could deliver that result remarkably well.

\footnotetext{
${ }^{123}$ LAC, MG32, Series B35 (Walter Gilbert Dinsdale fonds), Volume 79, File 3 - File Title: "Capital Punishment. General 1975," Joyce King to "Walter," May 16, 1975.

${ }^{124}$ House of Commons Debates (31 January 1973), 835 (Ian Arrol, MP - Progressive Conservative, York East, ON).

${ }^{125}$ W.E. Beales, letter to the editor, Toronto Star, September 6, 1975, p. B3.

${ }^{126}$ Guy Desrosiers, letter to the editor, Toronto Star, April 26, 1976, p. C5. For additional examples in the same vein, broadly speaking, as the three quotations in this paragraph, see C.M. Bain, letter to the editor, Globe and Mail, December 28, 1972, p. 6; LAC, MG32, Series B35 (Walter Gilbert Dinsdale fonds), Volume 79, File 2 - File Title: "Capital Punishment. General 1973," John Kroeker, President, Canadians for Responsible Government, to "Dear Member of Parliament," January 26, 1973; S.A. Melrose, letter to the editor, Toronto Star, May 23, 1973, p. 7; W.E. Beales, letter to the editor, Toronto Star, July 19, 1975, p. B3; B. Victor Potter, letter to the editor, Toronto Star, August 13, 1975, p. B5; William E. Rae, letter to the editor, Toronto Star, September 27, 1975, p. B3; Roland Porter, letter to the editor, Toronto Star, March 8, 1976, p. C5; John D. Wheatley, letter to the editor, Toronto Star, June 4, 1976, p. B5.
} 
One 1973 speech illustrated how, given the existence of doubts about deterrence, critiques of permissiveness, of current criminal justice, and of rehabilitative expectations could jointly contribute to an affirmation of incapacitation - in this case, incapacitation of a variety useful in an abolitionist context. "From my observation of murder cases about which I have personal knowledge," asserted MP Gordon Ritchie, "the deterrence of capital punishment was only vaguely recognized by the murderer when he carried out his crime." But he suggested "that most murderers are of distinct personality types" and "that these people always will have" the "personality deficiencies" out of which their homicidal deeds emerged. "Faced with the same circumstances, a murderer will always repeat the crime." Accordingly, "these people should be removed from society forever. In other words, I think that life imprisonment should mean life imprisonment." After all, "[w]e seem to be living in a very permissive society and I believe that one of the public's concerns and anxieties is over the laxity of a penal system that allows murderers to be paroled after what seems a short time and again inflicted on the public." In short, if the regrettable reality of murderers' nature seemed to suggest that parliamentarians should take up some vision other than rehabilitation, then Ritchie could easily judge it wise to fear permissiveness, and to favour incapacitation. ${ }^{127}$

${ }^{127}$ House of Commons Debates (23 May 1973), 4023-4024 (Gordon Ritchie, MP - Progressive Conservative, Dauphin, MB). The quotations are from page 4023. Although important parts of Ritchie's speech seemed to promote a pro-abolition perspective, it is difficult to label the speech as a whole as definitively retentionist or abolitionist. His second-reading vote on the largely abolitionist legislative effort of this time went in the "yea" column, his third-reading vote in the "nay" column. See Journals of the House of Commons of Canada, $1^{\text {st }}$ Session, $29^{\text {th }}$ Parliament, Volume 119, No. 91 (29 May 1973), and No. 156 (24 October 1973). 


\section{Pragmatic, Retributive, or Bloodthirsty? Interpretations of Retentionist Public} Opinion

Ritchie had plenty of company in the effort to identify the nature of "the public's concerns and anxieties" regarding issues pertinent to the death-penalty controversy. In fact, the matter captured a great deal of attention among debaters in the 1970s. Any observers willing to look to Gallup polls for a sense of Canadians' mind on the death penalty since the mid-point of the century might have concluded that not all Canadians of the 1950s and 1960s had been set in their ways. Seventy-one percent of the nation's residents thought in pro-capital-punishment terms in 1953; by contrast, 52 percent did so in 1958, 51 percent in 1960, 56 percent in 1965, and 53 percent in $1966 .{ }^{128}$ In the 1970s, however, observers faced the challenge of interpreting a once-again-acute retentionist impulse that appeared to be carrying the day within the citizenry. Many parliamentarians certainly appeared to believe that this impulse was for real. Both the correspondence initiated by citizens themselves and MPs' own efforts to use quasi-polling techniques fostered that belief. One abolitionist informed his fellow parliamentarians that "[m]y mail is running between 95 per cent and 99 per cent in favour of retaining the death penalty." 129 The abolitionist point of view was probably not swamped quite that badly in

\footnotetext{
${ }^{128}$ See Canadian Institute of Public Opinion, "Capital Punishment Is Favored by 71 P.C.; Hanging in Disfavor," Toronto Daily Star, April 22, 1953, p. 4; Canadian Institute of Public Opinion, "Public Opinion Swinging against Noose," Toronto Daily Star, October 4, 1958, p. 7; Canadian Institute of Public Opinion, "Growing Minority Would Ban Hangings," Toronto Daily Star, February 27, 1960, p. 7; Canadian Institute of Public Opinion, "Canadians Still in Majority for Keeping Death Penalty," news release (The Gallup Report), February 24, 1965; Canadian Institute of Public Opinion, "Canadian Public Not Ready to Abolish Death Penalty," news release (The Gallup Report), February 23, 1966; see also Fattah, Study of a Social Attitude, 1-3, 105. Cariboo, BC).

${ }^{129}$ House of Commons Debates (31 January 1973), 846 (Len Marchand, MP - Liberal, Kamloops-
} 
most MPs' mailboxes, but if MPs' claims can be believed, the retentionists still beat their opponents by a mile in the battles of the stamp, the envelope, and the mail-in questionnaire. ${ }^{130}$

The citizenry in toto probably contained slightly fewer fans of retention than might have been surmised from these patterns of advocacy. To hear the Gallup pollsters tell it, capital punishment captured Canadians' endorsement in 1971 to the tune of 63 percent, ${ }^{131}$ with 69 or 79 percent on the retentionist side in 1975 , depending on the range of murder scenarios to which the penalty was to apply. ${ }^{132}$ However, Gallup polls in 1976 created a more ambiguous impression. For example, early in February, just 48 percent indicated that the future establishment of "better law and order" would not alter their own pro-capital punishment stance. ${ }^{133}$ Furthermore, as academic observers noted, the

\footnotetext{
${ }^{130}$ See, for example, House of Commons Debates (29 January 1973), 735 (Eldon Woolliams, MP Progressive Conservative, Calgary North, AB); (30 January 1973), 804-805 (Doug Rowland, MP - NDP, Selkirk, MB); (31 January 1973), 832 (Donald Munro, MP - Progressive Conservative, Esquimalt-Saanich, BC); (14 May 1973), 3717 (H.T. Herbert, MP - Liberal, Vaudreuil, QC); (15 May 1973), 3765 (Tom Cossitt, MP - Progressive Conservative, Leeds, ON); (22 May 1973), 3961 (Cyril Symes, MP - NDP, Sault Ste. Marie, ON); (23 May 1973), 4039 (John Harney, MP - NDP, Scarborough West, ON); (17 June 1976), 14591 (Peter Bawden, MP - Progressive Conservative, Calgary South, AB). For further confirmation, see Chandler, Capital Punishment in Canada, 137. But for somewhat different results, see House of Commons Debates (14 May 1973), 3724 (Elias Nesdoly, MP - NDP, Meadow Lake, SK); (5 July 1976), 15029 (Les Benjamin, MP - NDP, Regina-Lake Centre, SK).

${ }^{131}$ See Toronto Daily Star, "63\% in Support of Restoring the Death Penalty in Canada," February 2, 1972, p. 7; see Canadian Institute of Public Opinion, "63\% Want Death Penalty Restored for Murderers," news release (The Gallup Report), February 2, 1972; see also Fattah, Study of a Social Attitude, 4. Although the news release informing the public of this poll appeared in 1972, see Chandler, Capital Punishment in Canada, 50-51, 72-73 n. 35 for evidence that the polling data dated from 1971. Throughout this thesis I have used the year 1971 when referring to this poll, even though certain authors other than Chandler (e.g. Fattah) tended to associate it with the year 1972.

${ }^{132}$ See Canadian Institute of Public Opinion, "Canadians Not Ready to Abolish Capital Punishment," news release (The Gallup Report), April 16, 1975; see Fattah, Study of a Social Attitude, 5.

${ }^{133}$ See Canadian Institute of Public Opinion, "48\% Want Capital Punishment: Better Law \& Order Not Enough," news release (The Gallup Report), March 3, 1976. For somewhat ambiguous evidence that perhaps 59 percent subscribed to a retentionist viewpoint a few weeks subsequent to the third-reading vote on the abolitionist legislation, see Canadian Institute of Public Opinion, "Most Don't Know MP's Vote on Capital Punishment," news release (The Gallup Report), September 22, 1976. But for a 68-to-75 percent pro-death-penalty result in a 1977 poll, see Canadian Institute of Public Opinion, "Large Majority of
} 
retentionist camp probably most often appeared bigger and tougher after a poll had occurred than it would have looked if reality had been fully visible. ${ }^{134}$ For instance, some of the apparent retentionists on whom pollsters reported probably maintained pro-capitalpunishment attitudes with respect to only a few unusual criminal scenarios, while preferring that the majority of murderers be spared execution. ${ }^{135}$

Nevertheless, in the eyes of many - and probably most — observers, Johnny Canuck generally held a retentionist point of view. ${ }^{136}$ Some considered this to be part of a broader ethos. As one New Democrat said in 1976, "Society is moving very far to the right." He put it more colourfully earlier in his speech, perhaps having a bit of fun with hyperbole:

our judges will become more and more conservative and react more to the general tone of society as society becomes less progressive and people draw together for collective security. They will be more like the Ku Klux Klan five years from now than the progressive judges of five or ten years ago. ${ }^{137}$

Most debaters did not mention the Ku Klux Klan when discussing the ethos associated with current Canadian retentionism. But a number did wonder about the

Canadians Still Favor Capital Punishment," news release (The Gallup Report), August 6, 1977.

${ }^{134}$ See Chandler, Capital Punishment in Canada, 43-48; see Fattah, Study of a Social Attitude, 8284,95 .

${ }^{135}$ See Chandler, Capital Punishment in Canada, 43-48.

${ }^{136}$ One letter writer in 1976 referred to "the 80 or so per cent of Canadians favoring retention of capital punishment" - J.R. Dunsford, letter to the editor, Toronto Star, June 30, 1976, p. B5. Others who liked to use the figure 80 percent, or some expression incorporating 80 percent (e.g. "perhaps 80 per cent" - Hilliard G. Beare, letter to the editor, Toronto Star, July 5, 1976, p. C5), included D.J. Goodspeed, letter to the editor, Toronto Star, March 17, 1976, p. B5; W.E. Beales, letter to the editor, Toronto Star, May 21, 1976, p. B5; F.B. Adams, letter to the editor, Toronto Star, May 21, 1976, p. B5; James Sloan, letter to the editor, Toronto Star, June 30, 1976, p. B5; Girard Scully, letter to the editor, Toronto Star, July 3, 1976, p. B3; G.H. Clement, letter to the editor, Toronto Star, July 10, 1976, p. B3; W. Johnston, letter to the editor, Toronto Star, July 31, 1976, p. B3. For a journalist's statement that "opinion polls say eight of 10 Canadians favor retention of the death penalty," see Geoffrey Stevens, "A Day of High Drama," Globe and Mail, June 23, 1976, p. 6. Timiskaming, ON).

${ }^{137}$ House of Commons Debates (31 May 1976), 14010-14011 (Amold Peters, MP - NDP, 
nature of that ethos, and of the ideas and sentiments that were leading Canadians toward a retentionist frame of mind. Those interested in the issue received a little help from Gallup investigators, who gathered some pertinent data in 1971. According to the February 1972 news release in which the investigators publicized their discoveries, 63 percent of the interviewed individuals qualified as retentionists. But the news release also sorted the retentionists into several subsets, according to the type of pro-death-penalty argument that they considered compelling. One large subset -64 percent of the retentionists - included all those whose thinking fell into a category summarized in the news release as "[n]umber of murders has increased; need death penalty as a deterrent to crime." Only 14 percent belonged to the group chiefly concerned with such issues as "[s]imple justice; those who take life, should pay with theirs." Some retentionists in the 1970s may have found rhetorical advantages in flying the flag of incapacitation, as discussed earlier in the chapter, but at least at the time of this poll, only seven percent chose to rally around the idea that "[1]ife sentences too often end with parole, and free prisoners to kill again." The final three groups included those persons emphasizing less popular points or offering no explanation for their views. If this poll had shone sufficient light on the current scene, then the most typical Canadian retentionist could claim that pragmatic blood flowed in his veins, and that retributive views held no preeminent place in his heart. ${ }^{138}$

\footnotetext{
${ }^{138}$ See Canadian Institute of Public Opinion, "63\% Want Death Penalty Restored for Murderers," news release (The Gallup Report), February 2, 1972; see Fattah, Study of a Social Attitude, 64-65; see Vidmar, "Attitudes toward the Death Penalty," 337-339, 352; see Chandler, Capital Punishment in Canada, 50-51, 72-73 n. 35.
} 
It is unclear whether parliamentarians took much notice of these details in the poll. ${ }^{139}$ However, especially in the 1973 debate, a number of politicians did seem to prefer this type of interpretation of retentionists' thinking. "Canadians are not vicious, nor vindictive, nor vengeful," contended MP Donald Munro. "They are compassionate people, but they are fearful of the direction in which Canadian society is heading." They wanted Parliament "to provide them with the security and safety in society that they see slipping away from them." ${ }^{140}$ Although it made perfect sense for a retentionist like Munro to say this, certain abolitionists liked the idea as well. Admittedly, a number of abolitionists continued to point to potential vengefulness when discussing some retentionist perspectives. ${ }^{141}$ But while some other abolitionist MPs also took note of the idea that a stark retributivism or a deep mean-spiritedness might possibly have latched onto the citizenry, a few of them exhibited a striking preference for discounting this possibility and offering a more charitable interpretation of the retentionist mind. "I am convinced that the people of Canada do not lust after the blood of murderers," argued one New Democrat. "I am convinced that if at the moment the majority tend to favour capital punishment, it is because they want an assurance that their lives and the lives of their loved ones will not be placed in jeopardy because of inadequacies in our penal system."142

\footnotetext{
${ }^{139}$ For one abolitionist speech noting and briefly interpreting this poll, see House of Commons Debates (29 January 1973), 739 (B. Keith Penner, MP - Liberal, Thunder Bay, ON).

${ }^{140}$ House of Commons Debates (31 January 1973), 833 (Donald Munro, MP - Progressive Conservative, Esquimalt-Saanich, BC).

${ }^{141}$ For just two examples, see House of Commons Debates (16 May 1973), 3846-3847 (David Lewis, MP - NDP, York South, ON); (24 July 1973), 5950 (Ed Broadbent, MP - NDP, Oshawa-Whitby, ON).

${ }^{142}$ House of Commons Debates (30 January 1973), 807 (Doug Rowland, MP - NDP, Selkirk, MB); see also (15 May 1973), 3761-3762 (Grace MacInnis, MP - NDP, Vancouver Kingsway, BC). For other instances in which abolitionists downplayed Canadians' devotion to vengefulness but offered a more charitable interpretation that still centred upon non-pragmatically-oriented viewpoints on the citizenry's
} 
The rhetoric of "permissiveness" could aid MPs in the effort to characterize the going retentionist view as relatively benign. Retentionist Reg Stackhouse denied that "the desire to retain the death penalty shows some kind of blood lust or perverse sadism," an idea which "misjudges the Canadian people." Earlier in his speech he had described what he considered to be citizens' actual outlook regarding the pro-abolition legislation under debate: "it symbolizes the permissiveness that they believe is a threat to their safety." 143 Correspondence from residents of his riding revealed something important, believed abolitionist Doug Roche: "most of those who support the death penalty do so out of a desire for more safety in society and less so for revenge or retributive justice." He pointed out "just how strong is the desire for improved security in our country today. We are paying a heavy price for the permissiveness of modern society."

Some abolitionist MPs might have wanted to discern a pragmatic expression on the face of Canadian retentionism in order to be in position to show that retentionist constituents could see their anti-crime vision accomplished even under an abolitionist regime. ${ }^{145}$ But for at least some parliamentarians, the instinct not to insult the citizenry probably entered the equation as well. If retributive thinking sometimes found itself ethically unwelcome in the Canadian public arena, vengefulness fared yet worse, and bloodthirstiness and "barbarism" had even fewer friends. Parliamentarians' awareness of

part, see House of Commons Debates (23 May 1973), 4040 (John Harney, MP - NDP, Scarborough West, ON); (29 May 1973), 4225-4226 (Gerald Baldwin, MP - Progressive Conservative, Peace River, AB) [but see also (24 July 1973), 5923 (Gerald Baldwin, MP)].

${ }^{143}$ House of Commons Debates (14 May 1973), 3739 (Reg Stackhouse, MP - Progressive Conservative, Scarborough East, ON).

${ }^{144}$ House of Commons Debates (22 May 1973), 3976-3977 (Douglas Roche, MP - Progressive Conservative, Edmonton-Strathcona, $\mathrm{AB}$ ).

${ }^{145}$ For an example in which some of this dynamic comes through, see ibid., 3977-3978. 
this, and their own immersion in the same moral culture that shaped the public arena, underlay some MPs' unwillingness to suggest that such viewpoints and dispositions had become prevalent among a majority of Canadians. Probably this instinct for magnanimity arose partly from MPs' desire for a reciprocal response from their constituents. Based on his parliamentary speech in the 1973 debate, MP Mark Rose certainly does not appear to been primarily interested in ingratiating himself with constituents. Even so, perhaps a few of his statements do provide a good hint of the mixture of commitments, expectations, and interests relevant to the outlook MPs developed and the decisions they made in light of their constituents' input. Though Rose seems to have seen potential for retributive and vengeful dynamics within the retentionist viewpoint, he denied that the pro-death-penalty trend involved "a citizen regression into a state of barbarism." He certainly did not want to believe, or at least not to have to say, that such a "regression" was occurring. As he pointed out,

I would like my constituents, and people all across Canada, to know that Members of Parliament on both sides of this moral question have tried desperately to analyse the rationale behind current public sentiment in favour of returning to the noose. Regardless of the outcome of the vote, I insist that no public-be-damned attitude exists on the part of elected representatives in this chamber. ${ }^{146}$

In sum, moral assumptions formed an essential, even if sometimes unconscious, element of the mentality out of which MPs operated as they sought to nurture constituents' loyalty, to meet constituents' needs, and to discuss retentionist constituents' perspective in terms conducive to success in both tasks.

\footnotetext{
${ }^{146}$ House of Commons Debates (29 May 1973), 4226-4228 (Mark Rose, MP - NDP, Fraser Valley West, BC). The quotation is from page 4227.
} 
To many retentionist members of the public, retributive claims of one variety or another did in fact appear to be the best pro-capital-punishment ideas, and some retentionist letter writers were quite willing to say so. ${ }^{147}$ Yet a good number of others would have appreciated the attempts of certain MPs to claim that pragmatic thinking featured more prominently among retentionist citizens. According to one letter to the editor in the Toronto Star in May 1976, pro-death-penalty Canadians “don't thirst for revenge or gloat at the prospect of hanging wretches. We are practical: We want them to be unable to commit further horrible crimes and we don't want to pay to keep them alive." It may be possible that this citizen confirmed his non-vengefulness and nonsadism simply to prove what complete allegiance he maintained to a "practical" ethos. ${ }^{148}$ For some other writers, on the other hand, the reverse was true: talking about incapacitation, an ultra-pragmatic concept easily incorporated into death-penalty advocacy, served partly as a means of dissociating themselves from brutality or revenge. One writer who did appear to think in at least partially retributive terms nevertheless knew how to use what could sound like incapacitation-themed phrases to cast retentionists in a virtuous light. Executing a convict, he insisted, "is not a matter of vengeance. We do not hate him. We do not want to hurt him. We just want to be rid of him."149 According to another retentionist,

${ }^{147}$ See, for example, A. Stelmaschuk, letter to the editor, Toronto Star, May 28, 1973, p. 7; David Fox, letter to the editor, Toronto Star, November 8, 1973, p. B5; Kathleen O'Brien Zeagman, letter to the editor, Toronto Star, October 9, 1975, p. B5; Gerard Scully, letter to the editor, Toronto Star, March 6, 1976, p. B3.

${ }_{148}^{148}$ Robert Olson, letter to the editor, Toronto Star, May 6, 1976, p. B5.

${ }^{149}$ LAC, MG32, Series B35 (Walter Gilbert Dinsdale fonds), Volume 79, File 2 - File Title: "Capital Punishment. General 1973," John Kroeker, President, Canadians for Responsible Government, to "Dear Member of Parliament," January 26, 1973. 
I don't seek vengeance nor do I wish to be cruel no matter how beastly the murderer was. A life in prison is more cruel than elimination from society of the ruthless killer, both to the killer and to society.

A prisoner can always escape and is then free to kill again.

I wish to save the taxpayer $\$ 15,000$ per year and to protect the lives of those men who have the responsibility of guarding this type of person.

I would plead to eliminate hanging and substitute a more humane method.... I have no wish, no matter how brutal he is, to see another human suffer....

Surely you can not think of us who feel this way as being illogical and inhuman monsters. ${ }^{150}$

To think in a pragmatic vein sometimes seemed to be the ethically safest route.

If Gallup pollsters, certain MPs, and some members of the general public itself

suggested that no more than modest overlaps existed between retributive thinking and the retentionist energy among Canadian citizens in the 1970 s, certain academic observers spoke of retentionists in terms that created a rather different impression. On December 23, 1972, the Globe and Mail printed a letter from the University of Windsor's Lawrence La Fave, who taught in the school's Psychology Department. La Fave had warm words for Ezzat Fattah's report concerning deterrence. He noted, however, that

[s]ome people, perhaps convinced their own lives are failures, have become bloodthirsty; they have a sadistic need for capital punishment. Having grown up in a so-called Christian culture, they may rationalize this need - convincing themselves that capital punishment acts as a deterrent. Such individuals, regardless how overwhelming the evidence against capital punishment as a deterrent becomes, will remain unconvinced. ${ }^{151}$

Nearly two years later, a less strongly worded but much more extensive academic

\footnotetext{
${ }^{150}$ Thomas Wilson, letter to the editor, Toronto Star, April 3, 1975, p. C5. See also L. Thomson, letter to the editor, Toronto Star, September 1, 1975, p. C5; see also John Huberman, "Two-Time Killers Cannot Be Cured," Vancouver Sun, April 1, 1976, p. 6 - a copy of this article is also found in LAC, MG32, Series B35 (Walter Gilbert Dinsdale fonds), Volume 79, File 5 - File Title: "Capital Punishment. General, Feb.-July 1976," attached to Memorandum, Bill Clarke to Progressive Conservative Caucus, April $14,1976$.

${ }^{151}$ Prof. Lawrence La Fave, Psychology Department, University of Windsor, letter to the editor, Globe and Mail, December 23, 1972, p. 7.
} 
discussion of Canadian retentionism appeared in the Canadian Psychologist. The University of Western Ontario's Neil Vidmar had been curious about the mentalities that citizens maintained with respect to punishment, especially capital punishment. Judging by appearances emerging from Gallup polling in 1971, Canadian retentionists' mind-set most typically steered their attention toward deterrence or other utilitarian issues when they discussed the capital-punishment quandary. But Vidmar was not sure what to make of such an idea. Among other reasons for skepticism, Vidmar suspected that ideas about and interest in deterrence might possibly take up more space in retentionists' mouths than in their psyches. Conversely, some retentionists might have kept a goodly dosage of retributive passion warm, dry, and well-fed in their hearts while barring it from their mouths, preferring to voice a more "socially desirable" perspective. ${ }^{152}$ So Vidmar tried his hand at investigating the matter with a more extensive and refined empirical methodology, putting this methodology to work, it should be noted, with just a modest number of interviewees - roughly 150 southern Ontarians. ${ }^{153}$

When all was said and done, Vidmar believed he had no need to apologize for redundant discoveries: he was not merely conveying ideas already derivable from Gallup records. Instead,

[a] major conclusion from the present study is that the motive of retribution is a very important factor in public attitudes favoring the death penalty and for some persons, possibly for a majority and certainly for those who most strongly favor it, retribution appears to be more important than the utilitarian motive of

\footnotetext{
${ }^{152}$ See Neil Vidmar, "Retributive and Utilitarian Motives and Other Correlates of Canadian Attitudes toward the Death Penalty," The Canadian Psychologist 15, no. 4 (October 1974): 337-341, 352 353.

${ }^{153}$ See ibid., 337, 339-344, 352-353
} 
deterrence. ${ }^{154}$

The study delved into additional matters too, including "authoritarianism, punitiveness, dogmatism, and prejudice." Larger doses of all four qualities surfaced among retentionist citizens than among abolitionists. ${ }^{155}$

A brief discussion of certain details in the article will provide a slightly clearer sense of the proportion of retentionists within whose ideas on capital punishment the study seemed to pinpoint a primarily retributive heartbeat. Vidmar's careful wording ensured that his argument did not wriggle out of its proper evidentiary harness. There was a reason why he had to include the qualifier "possibly" when suggesting that the retentionists whose devotion to retribution outshone their passion for deterrence might actually add up to more than half of all retentionists. ${ }^{156}$ For one thing, over 60 percent of retentionists saw greater merit in the type of capital punishment that was intended "to serve as an example to other people and thus deter them from committing similar crimes" than in capital punishment instituted "to make the guilty person pay with his life for killing another person." 157 On the other hand, Vidmar could point out the decision that retentionists reached when considering the following query: "If you could be convinced that the death penalty is no deterrent to murder, would you still favour it?" According to "fully 55 percent of" retentionists, their pro-capital-punishment loyalties would not die in such a scenario. ${ }^{158}$

\footnotetext{
${ }^{154}$ Ibid., 352; see also 337, 349.

${ }^{155} \mathrm{Ibid} ., 337,342,351-354$. The quote is from the abstract on page 337.

${ }_{157}^{156}$ See ibid., 352.

${ }^{157}$ Ibid., 345; see also 349.

${ }^{158}$ Ibid., $345,349$.
} 
Vidmar considered this latter phenomenon "revealing," if by no means perfectly clear. "While this result in no way totally rejects the existence of a deterrence motive," he noted, "it does indicate that for more than half of the capital punishment advocates the motives of retribution or removing criminals from society by killing them were important enough to maintain the advocacy even when the deterrence rationale was eliminated."159 This latter statement drew attention, after a fashion, to two issues that limited the degree to which Vidmar could treat the thoughts of the tenaciously retentionist 55 percent as evidence of a preeminent commitment to retributivism. First, in some cases these individuals might have drawn inspiration first and foremost from the idea not of retributive execution, but rather of the soundly utilitarian incapacitating execution. Vidmar did not stress the point, but it was not as if there were no particular evidence in the study that might suggest this possibility. On the contrary: according to three quarters of the retentionists, the fact that capital punishment "keeps murderers from repeating their crimes" deserved a higher place on the hierarchy of pro-capital-punishment considerations than did the claim that "[m]urderers should get what they deserve."160 Secondly, Vidmar hinted at, without spelling out baldly, another point. To wit, if a given retentionist currently found retributive ideas so compelling that he would have remained true to the retentionist cause despite at some future point finding himself bereft of all nonretributive inspiration, that did not in itself preclude the possibility that at the present time retributive ideas concerning capital punishment still captured his interest less than did the

\footnotetext{
${ }^{159}$ Ibid., 349.

${ }^{160} \mathrm{Ibid} ., 234$; see also 338-339, 347, 349.
} 
possibilities of deterrence. ${ }^{161}$ Nevertheless, if such issues made it necessary for Vidmar to insert the term "possibly" when noting that the retentionists whose retributivism exceeded their commitment to deterrence might constitute "a majority," further evidence did make it quite plausible for him to describe the retributive outlook as "very" influential. ${ }^{162}$ And if any observers had formerly been inclined to point to 1971 Gallup data to downplay Canadian retentionists' attraction to retributive ideas, they would have found major cause for reconsideration within Vidmar's article. ${ }^{163}$

And perhaps a few of the retributive notes that Vidmar had already recorded would prove to have even a slightly starker tenor if explored in a scholarly project of even higher calibre. If Vidmar had been wary of some retentionists' possible propensity for playing it mum with the retributive notions dancing in their heads, he also, perhaps tellingly, wondered whether some retentionists might take the same approach to viewpoints associated with the more specific category of revenge. "Only 18 percent of our sample personally endorsed revenge as the major reason for the death penalty," he noted, "but it seems highly possible that interview demand characteristics or social desirability could have shaped those answers." Such a suggestion gained further plausibility, he believed, when one considered the punitiveness and authoritarianism that the investigation had revealed among some retentionists. ${ }^{164}$

\footnotetext{
${ }^{161}$ See ibid., $342,349$.

${ }^{162} \mathrm{Ibid} ., 352$; see also $349-350$. I should note that my analysis here, which stresses the counterevidence against the possible centrality of retributivism much more strongly and explicitly than Vidmar himself did, draws only from the evidence that Vidmar discussed in the article, not, of course, from his raw interview data. If by chance the raw data actually revealed that the counter-points I have raised could not have held true, Vidmar does not appear to have presented such evidence in the article.

${ }^{163}$ Cf. ibid., 347, 349-350, 352.
Ibid., 352-353.
} 
One could perhaps be forgiven for acquiring the vague — and possibly erroneous - impression that Vidmar preferred to highlight rather than minimize the prevalence of the retributive dynamics detected through the study. Such a preference was of course perfectly logical: in informing readers about these dynamics, he was calling their attention to a new insight - one of the principal insights that the article could provide. At the same time, perhaps the retributive theme proved useful on more than one level. Consider the following statements from Vidmar's final paragraph:

[W] hile general levels of support for capital punishment are quite high, a substantial number of persons may favor it for reasons that are inconsistent with important Canadian values and goals. Canadian people and institutions formally endorse the principles of humane legal justice, democratic as opposed to authoritarian values, and equality for all citizens. It was found, however, that persons favoring the death penalty were more likely than persons opposed to the death penalty to favor punitive and retributive means of dealing with criminals, to be inclined to endorse authoritarian instead of democratic social and political beliefs, and to score high on measures of prejudice. Many persons probably favor capital punishment because they believe it is a deterrent to crime but our findings suggest that some persons, perhaps those most vociferous in their advocacy, favor it for less desirable motives.... Parliamentary, governmental, and legal decisionmakers should be advised that mere levels of public support for an issue do not tell the whole story. ${ }^{165}$

Statistical investigations and psychology articles might have dealt primarily in intellectual wares geared to the satisfaction of empirical curiosity, but they could also reserve a little strategic air time for the reiteration of normative ideas. Norms, after all, served as key weapons with which to challenge the citizenry's retentionist preferences. As another scholar would soon point out, discussion of deterrence and associated statistical delights

\footnotetext{
${ }^{165}$ Ibid., 354. A fairly similar quotation, which probably came from an earlier version of Vidmar's article (see ibid., 337 n.1), appears in one abolitionist speech in October 1973 - see House of Commons Debates (19 October 1973), 7058 (Peter Reilly, MP - Progressive Conservative, Ottawa West, ON).
} 
had won the abolitionist cause disappointingly little ground among workaday

Canadians. ${ }^{166}$ There was a time to play the normative card and deploy ethical arguments.

If Vidmar wrote in a dispassionate scholarly tone, the academic pen would again find occasion to deal with the issue in blunter language, as La Fave had done. When the Solicitor General's department had needed to think perceptively about murder statistics, Ezzat Fattah had proved himself helpful. Having also encountered a set of complexities pertaining to the citizenry's outlook on capital punishment, the department felt a need for more research and analysis, and Fattah turned out to be the figure to take up the task. Departmental officials got to read his thoughts in 1975, in the form of a report entitled The Canadian Public and the Death Penalty: A Study of a Social Attitude. His discussion, which synthesized and explicated information from many polls and scholarly works, was far from boring. ${ }^{167}$

It appears that Fattah felt two different urges as he crafted his report. In some respects he wished to show what a sharp retentionism had emerged in 1970s Canada; in other respects he wanted to convey how limited Canadians' retentionist loyalties really were. Thanks to such vexations as the murder of famous leaders in 1960s America, the punches thrown by terrorism within more than one section of the world community, and the sick stomach that Canada itself had acquired through the October Crisis, Canadians in the 1970s had more desire to talk in retentionist language than they had felt during the

\footnotetext{
${ }^{166}$ See Fattah, Study of a Social Attitude, 76-77.
}

${ }^{167}$ Ezzat A. Fattah, The Canadian Public and the Death Penalty: A Study of a Social Attitude ([Ottawa, ON?], [1976]); see House of Commons Debates (21 April 1975), 5032-5033; (24 November 1975), 9369; (13 April 1976), 12782; (29 April 1976), 12994; see also Canadian Press, "Sociologist Clarifies Capital Punishment Report," Globe and Mail, April 8, 1976, p. 8; Ezzat A. Fattah, letter to the editor, Globe and Mail, June 7, 1976, p. 6. 
decade prior to 1967, suggested the report. Pointing to 1975 Gallup polling, Fattah suggested that the pro-retention portion of the citizenry truly had welcomed a large batch of additional adherents into the retentionist camp since the nation's centennial year, and that if this camp had soon lost some of the bandwagon retentionists of the October Crisis, as many or more replacements had since emerged. In the end, observers would have to admit that "a hardening of attitude toward crime and punishment" had come calling in North America. ${ }^{168}$ On the other hand, some observation and research suggested that, although many citizens donned an apparently retentionist hat in the presence of pollsters, some of these retentionists would probably at times judge it quite proper for authorities not to call the executioner into action, despite the occurrence of the type of crime that a retentionist might typically be expected to view as a death-worthy offence. ${ }^{169}$ And an individual who spoke like a retentionist in a polling context could still remain largely oblivious to the controversy otherwise. Fattah captured this side of the coin with a statement that caught a journalist's eye: "The fact is, simply, that the public doesn't care about the death penalty, except when some dramatic crime or trial influences passions and inflames emotions." 170

The duel between these two themes also emerged in Fattah's portrayal of the ethos from which Canadians tended to draw energy and direction when reaching conclusions

\footnotetext{
${ }^{168}$ See Fattah, Study of a Social Attitude, first page of Abstract, first page of Summary, 1-6, 74 (the quoted words are from p. 5); see Canadian Press, "Public Bloodthirsty about Hanging, Report Says," Globe and Mail, March 11, 1976, p. 9; Canadian Press, "Public Opinion on Hanging 'Bloodthirsty': Report," Toronto Star, March 11, 1976, p. A5.

${ }^{169}$ See Fattah, Study of a Social Attitude, 82-84, 95; see also Ezzat A. Fattah, letter to the editor, Globe and Mail, June 7, 1976, p. 6.

${ }^{170}$ Fattah, Study of a Social Attitude, 93; see also 73-76, 82, 94. This quote also appears in Canadian Press, "Public Opinion on Hanging 'Bloodthirsty': Report," Toronto Star, March 11, 1976, p. A5.
} 
about the propriety of the death penalty. Some of his statements created the impression that retentionists' belief in a harsh genre of sentencing for murder was in many cases complemented by a harsh vein in their character more generally. ${ }^{171}$ On the other hand, the report also suggested that the desire for "humanitarian" outcomes maintained a powerful and durable presence among Canadians. ${ }^{172}$ Similarly, Fattah placed some emphasis upon both retributive features and utilitarian elements in retentionists' outlook. The report pointed out the pertinent Gallup research from 1971, based on which one might infer that when retentionists participated in a discussion devoted to the evaluation of the death penalty, utilitarian issues would, more likely than not, enter the conversation often. ${ }^{173}$ But Fattah also suggested, albeit in a slightly tentative form, that "there seems to be strong evidence" suggesting "that the majority of capital punishment supporters ... support it on vindictive and retributive rather than utilitarian grounds." 174

The evidence may have been a little stronger in his mind than in reality. According to Fattah,

Vidmar (1974) examined the motivations of those who support the death penalty, and found that over half of them had a retributive motive as their basis of support. $56 \%$ of the respondents claimed that they would favor capital punishment even if they could be convinced it had no deterrent value. ${ }^{175}$ see also $67-69$.

${ }^{171}$ See Fattah, Study of a Social Attitude, first page of Abstract, fourth page of Summary, 57-62;

${ }_{172}^{172}$ See ibid., 95; see also Ezzat A. Fattah, letter to the editor, Globe and Mail, June 7, 1976, p. 6.

${ }^{173}$ See Fattah, Study of a Social Attitude, 64-66.

${ }^{174}$ Ibid., 67.

${ }^{175}$ Ibid., 65. The Vidmar study to which Fattah was referring here was the same article discussed in this thesis. David Chandler made a similar statement: "After careful analysis of a variety of measures of this motivation [retribution] to support the death penalty, Vidmar concludes that over half of those supporting it had a largely retributive motive as their basis of support" - Chandler, Capital Punishment in Canada, 67. 
This was actually the sort of poorly worded claim that Vidmar had avoided making. If Fattah was referring to the primary motive from which each individual within this 55 percent obtained his or her retentionist energy, then the evidence discussed in Vidmar's article appears, as explained earlier, to have permitted no such assertion. Rather, the true credit for the pro-death-penalty dedication of some persons within this 55 percent may have belonged primarily to the idea of incapacitation — an idea firmly associated with a utilitarian perspective. ${ }^{176}$ Still, if Fattah here stood in danger of unduly magnifying the retributive character of retentionists' outlook, the same could certainly not be said of all sections in the report: the Summary mentioned retentionists' utilitarian statements but pointed to retributive retentionist perspectives only by ambiguous implication. ${ }^{177}$

But perhaps the best way to delve further into the content and significance of the report is to examine how people discussed it in the press and in Parliament. The Solicitor General's department had had several months to think about the study by March 1976, at which point it became fair game for ordinary Canadians to read as well. ${ }^{178}$ The report may have dealt to some extent with both the onerous and the congenial aspects of the citizenry's disposition, but in the estimation of Canadian Press (CP), the main theme, or at least the most newsworthy theme, concerned the country's dark side. The March 11 edition of the Globe and Mail drew readers' attention to the CP article on the study by

\footnotetext{
${ }^{176}$ See Vidmar, "Attitudes toward the Death Penalty," 338-339, 345, 347, 349, as well as my discussion of this article earlier in the chapter. At another point in the report Fattah made a similar overstatement about Vidmar's study: "He found retribution to be more important than utilitarian motives in determining the attitude of persons favoring the death penalty" - Fattah, Study of a Social Attitude, 54-55.

${ }^{177}$ See Fattah, Study of a Social Attitude, fourth page of Summary.

${ }^{178}$ See House of Commons Debates (24 November 1975), 9369; see Canadian Press, "Public Bloodthirsty about Hanging, Report Says," Globe and Mail, March 11, 1976, p. 9.
} 
means of an eye-catching headline: "Public bloodthirsty about hanging, report says." According to the article itself, "[p]ublic opinion on capital punishment is described by criminologist Ezzat Fattah as "vindictive, retributive and bloodthirsty.",179 Among other things, the article also offered readers what was at times a slightly out-of-context taste, in either verbatim, slightly altered, or paraphrased form, of some of the more striking statements from the abstract and summary of the document. For instance, the article included the following quotation concerning a pro-capital-punishment stance: "Support also seems to be high among people who are insecure, who were severely brought up, and who are maladjusted socially.""180 Moreover, "“[p]eople who are opposed to hanging are people who feel secure, who were brought up by mild disciplinary methods, and who are pleased with life.",181 As well, “"[s]upport for capital punishment seems to be associated with prejudice, ethnocentrism, and low regard for values such as equality, forgiveness and love." $" 182$

Some Globe and Toronto Star readers felt rather peeved after encountering the

${ }^{179}$ Canadian Press, "Public Bloodthirsty about Hanging, Report Says," Globe and Mail, March 11, 1976, p. 9. The article also appeared in the Toronto Star, but in a somewhat different form - see Canadian Press, "Public Opinion on Hanging 'Bloodthirsty': Report," Toronto Star, March 11, 1976, p. A5.

${ }^{180}$ Canadian Press, "Public Bloodthirsty about Hanging, Report Says," Globe and Mail, March 11, 1976, p. 9; Canadian Press, "Public Opinion on Hanging 'Bloodthirsty': Report," Toronto Star, March 11, 1976, p. A5. The original quotation is found in Fattah, Study of a Social Attitude, first page of Abstract; see also fourth page of Summary and p. 57.

${ }^{181}$ Canadian Press, "Public Bloodthirsty about Hanging, Report Says," Globe and Mail, March 11, 1976, p. 9; Canadian Press, "Public Opinion on Hanging 'Bloodthirsty': Report," Toronto Star, March 11, 1976 , p. A5. The original quotation, which contains "it" in place of "hanging," is found in Fattah, Study of a Social Attitude, fourth page of Summary - note the context in which it appears on this page. See also p. 57.

${ }^{182}$ Canadian Press, "Public Bloodthirsty about Hanging, Repoit Says," Globe and Mail, March 11, 1976, p. 9; Canadian Press, "Public Opinion on Hanging 'Bloodthirsty': Report," Toronto Star, March 11, 1976, p. A5. The original quotation, which contains a "with" before "low," is found in Fattah, Study of a Social Attitude, fourth page of Summary. See also p. 59-60. 
article. Fattah believed that, partly (although not only) because of deficiencies in citizens' knowledge pertaining to the controversy, federal authorities who tried too hard to bring about consonance between their own intentions and citizens' present expectations would be pursuing a poor objective. ${ }^{183}$ Certain letters to the editor objected to this way of thinking. One writer suggested that Fattah had chosen "to heap hysterical abuse on the silly commonsense of the majority who dare to disagree with the prejudices of their betters." 184 Another thought that Fattah's recommendations "would seem to be more dictatorial than democratic." 185 Another believed that if the version of the CP article appearing in the Star had represented Fattah's views correctly, then Fattah was promoting "opinions as dangerous as those of the Mafia." As the writer saw it, "what Fatah [sic] is really saying is that we should have a democratic dictatorship, with remarkably little stress on the 'democratic."'186 However, if retentionists were not about to admit that Fattah was right, at least some of them did feel the moral heat when they heard of his analysis. "I suppose," wrote one,

that Fattah considers himself more moral than I because he would rather see a murderer decay in prison even though we have the alternative of removing this cancer from society with any number of painless means - not simply hanging.

The idea should not be to punish but to simply remove this threat to society as

\footnotetext{
${ }^{183}$ See Fattah, Study of a Social Attitude, fifth and sixth pages of Summary, 85-90, 92-95; see also Canadian Press, "Public Bloodthirsty about Hanging, Report Says," Globe and Mail, March 11, 1976, p. 9; Canadian Press, "Public Opinion on Hanging 'Bloodthirsty': Report," Toronto Star, March 11, 1976, p. A5; Canadian Press, "Sociologist Clarifies Capital Punishment Report," Globe and Mail, April 8, 1976, p. 8.

${ }^{184}$ D.J. Goodspeed, letter to the editor, Toronto Star, March 17, 1976, p. B5.

${ }^{185}$ E. Brown, letter to the editor, Toronto Star, March 17, 1976, p. B5.

${ }^{186}$ Ron Kenyon, letter to the editor, Toronto Star, March 22, 1976, p. C5. For other letters firing back at Fattah or his report, see Steven Dorsey, letter to the editor, Toronto Star, March 17, 1976, p. B5; John E. Mahoney, letter to the editor, Toronto Star, March 17, 1976, p. B5; Werner Hartmaier, letter to the editor, Toronto Star, March 20, 1976, p. B3; C. Boyd, letter to the editor, Toronto Star, March 20, 1976, p. B3; Hans George Classen, letter to the editor, Globe and Mail, March 22, 1976, p. 6; V.M. Marks, letter to the editor, Globe and Mail, March 30, 1976, p. 6.
} 
humanely as possible. ${ }^{187}$

Such a comment provides one more indication that although many Canadians might not have disdained retribution or exalted humaneness to such a thoroughgoing extent as Fattah, a large number of them, including many retentionists, found his basic ethical assumptions on these two matters to be compelling in many respects.

Fattah seems to have been less than pleased with the impression that the public had obtained of his study. On April 8 the Globe and Mail carried an article in which Canadian Press modified its description of his analysis. His report contained a number of statements that described the claims made by other researchers, and that he himself might not necessarily have endorsed had he been able to investigate the relevant phenomena directly. The earlier article, $\mathrm{CP}$ now noted, had gone wide of the mark in conveying the idea that Fattah himself was promulgating some of those ideas. ${ }^{188}$ Moreover, the earlier article had "erroneously reported ... that Dr. Fattah described public opinion on capital punishment as 'vindictive, retributive and bloodthirsty."' By contrast, the present article now revealed that the report's characterization of Canadians included a strong reference to their humaneness. But CP decided that it could help readers gain a sense of Fattah's actual discussion by letting them have their own look at a sizeable quotation from the study's conclusion. The report, $\mathrm{CP}$ pointed out, calls public opinion as expressed through juries on the issue of capital punishment "more humane than the law itself.

\footnotetext{
${ }^{187}$ Ross Parlette, letter to the editor, Toronto Star, March 30, 1976, p. B5. In a related vein, although it is not a response to Fattah, see Ian S. Johnston, letter to the editor, Globe and Mail, March 4, 1976, p. 6.

${ }^{188}$ See Canadian Press, "Sociologist Clarifies Capital Punishment Report," Globe and Mail, April 8, 1976, p. 8; see also Ezzat A. Fattah, letter to the editor, Globe and Mail, June 7, 1976, p. 6.
} 
"When capital punishment was the mandatory sentence for murder, the jury simply did not impose it in most cases.

"Should jury decisions be considered more accurate indicators of the state of public opinion than poll and survey results?

"And, even if public opinion is as hateful, as vindictive and as retributive as it often appears in poll results, isn't it the function of the law to hold the brute forces of hate and vindictiveness in check, rather than to encourage them?"189

Whatever impression this may have left with Globe readers, certain retentionist

MPs spoke less than glowingly about the report or Fattah himself during the parliamentary debate in May, June, and July. To be sure, some parliamentarians may have thought that the report's blunter passages reflected the truth quite well. According to one abolitionist MP, "Canadians have become an angry mob." ${ }^{190}$ A few retentionists, however, put the verbal boots to the "pet professor of the government by the name of Fattah."191 One MP denounced Fattah for "hav[ing] the gall and effrontery to lecture Canadians." "192 Another thought that Fattah "does not believe in democracy" and "is typical of the worst, the most dangerous group in social sciences." Indeed, "[i]t is with

${ }^{189}$ Canadian Press, "Sociologist Clarifies Capital Punishment Report," Globe and Mail, April 8, 1976, p. 8. The quotation offered in the article was a very slightly altered form of the actual statement the report, which was as follows: “...more humanitarian than the law itself. When capital punishment was the mandatory sentence for murder, the jury simply did not impose it in most cases. Should jury decisions be considered as more accurate indicators of the state of public opinion than poll and survey results?

"And, even if public opinion is as hateful, as vindictive and as retributive as it often appears in poll results, isn't it the function of the law to hold the brute forces of hate and vindictiveness in check, rather than to encourage them?" - Fattah, Study of a Social Attitude, 95.

${ }^{190}$ House of Commons Debates (5 May 1976), 13218 (David Collenette, MP - Liberal, York East, ON). For two seemingly positive references to Fattah's report, see House of Commons Debates (6 May 1976), 13262 (Robert Daudlin, MP - Liberal, Kent-Essex, ON); (18 May 1976), 13649 (Frank Philbrook, MP - Liberal, Halton, ON).

${ }^{191}$ House of Commons Debates (25 May 1976), 13806 (Donald Munro, MP - Progressive Conservative, Esquimalt-Saanich, BC).

${ }^{192}$ House of Commons Debates (11 May 1976), 13407 (Peter Masniuk, MP - Progressive Conservative, Portage, MB). 
that kind of guys that people wake up in a dictatorship."193

Fattah may not have felt fully satisfied by CP's April 8 attempt to improve upon its earlier description of his analysis. On June 7, the Globe and Mail ran a letter from Fattah that explained how the true meaning of his study differed from the description found in the March 11 article — an article that, as he saw it, "grossly distorts my opinions and findings." Among other things, he heavily emphasized the aspect of his analysis that had highlighted the good-natured, not-too-retentionist character of the citizenry. Indeed, he implied that the report had sought to make retentionists look less ferocious and implacable than they otherwise would have appeared. "The results of the polls, inaccurate as they are, would want us to believe that in their outcry for capital punishment the public is being vindictive, retributive and bloodthirsty," wrote Fattah. Contesting such a notion, he repeated the study's key statement concerning the citizenry's "humanitarian" habits, with subtle changes in wording that perhaps accentuated the point slightly more than in the report. ${ }^{194} \mathrm{He}$ also pointed out that, in dealing with such phenomena as authoritarianism, prejudice, and educational attainments, the study had merely been providing a general sense, based on statistical probabilities, of the characteristics of citizens within the retentionist camp relative to those of individuals within the abolitionist camp, rather than outlining definitive profiles applicable to every

\footnotetext{
${ }^{193}$ House of Commons Debates (14 May 1976), 13533 (Armand Caouette, MP - Social Credit, Villeneuve, QC). For other critical comments about Fattah or his report, see House of Commons Debates (10 May 1976), 13353 (Stan Darling, MP - Progressive Conservative, Parry Sound-Muskoka, ON); (8 June 1976), 14250 (W.C. Scott, MP - Progressive Conservative, Victoria-Haliburton, ON); (14 June 1976), 14464 (Bob Brisco, MP - Progressive Conservative, Kootenay West, BC); (12 July 1976), 15232 (Simma Holt, MP - Liberal, Vancouver-Kingsway, BC). Social Attitude, 95.
} 
individual retentionist or abolitionist. Also, perhaps in an effort to mitigate the disparaging connotations that readers might otherwise have perceived in what the report had revealed about the place of such phenomena in some retentionists' lives, Fattah seized the opportunity to portray such analysis as belonging to a genre of inquiry that offered safety from the discomfort of normative assessments. "Such findings," he asserted, "do not allow any value judgment and do not tell us who is right and who is wrong. They simply correlate certain psychological characteristics with certain attitudes."195

But Fattah had no intention of staying out of normative territory for the entirety of his letter. He repeated verbatim a statement from his report that had also been partially quoted in two previous articles:

It seems obvious that a punishment, any punishment, must be abolished if popular sentiment abhors it. But, on the other hand, public acceptance cannot and does not convey any legitimacy upon a cruel, demeaning and bestial practice such as the death penalty. ${ }^{196}$

And perhaps the form of this two-fold claim points to part of the reason for the two contrasting themes in his report. To be sure, the dueling emphases upon acutely retentionist developments and upon limited retentionist fervor presumably reflected the content of his sources to at least a great degree. But each of these two themes could also help to discourage authorities from dwelling upon the apparently retentionist perspective of the electorate, and from buying into any corresponding retentionist policy. In the

\footnotetext{
${ }^{195}$ Ezzat A. Fattah, letter to the editor, Globe and Mail, June 7, 1976, p. 6.

${ }^{196}$ Ibid.; Fattah, Study of a Social Attitude, 90; see also Canadian Press, "Public Opinion on Hanging 'Bloodthirsty': Report," Toronto Star, March 11, 1976, p. A5; see also Canadian Press, "Sociologist Clarifies Capital Punishment Report," Globe and Mail, April 8, 1976, p. 8.
} 
closing pages of his report, Fattah wished to suggest that, considering the ultimately humanitarian culture of the citizenry and the failure of many retentionists to muster a persistently fervent desire within themselves for capital punishment, authorities who would seek to pursue a retentionist justice policy might end up finding that they brought surprisingly little satisfaction to Canadians thereby. And considering the starker facets of the retentionist movement, any satisfaction that would result, whether it turned out to be widespread or meagre, might consist in substantial part of a "vindictive," "retributive," or "bloodthirsty" pleasure on the part of citizens, should what "the results of the polls would want us to believe" prove to be correct. In Fattah's view, if a policy promised to bring citizens into closer proximity to such pleasures as these, it was time to search for a better policy to implement. ${ }^{197}$

But Fattah's reference in his report to what "the results of the polls would want us to believe" about citizens' retributivism was a little curious. The one major Canadian poll that had clearly explored such aspects of retentionists' thinking as retributivism the Gallup poll in 1971 - had conveyed the impression that utilitarian issues captured retentionists' attention much more than retributive notions did. ${ }^{198}$ Admittedly, another Gallup poll that came to public attention in March 1976 could possibly have been interpreted as suggesting that the desire for a retentionist policy grew out of a retributive outlook in the case of at least 48 percent of Canadians - although the poll did not deal

\footnotetext{
${ }^{197}$ See Fattah, Study of a Social Attitude, especially 95, but for the overall drift of discussion that suggests, in my view, that Fattah was driving at (among other things) what I describe in this paragraph, see also $92-94$.

${ }^{198}$ See ibid., 64-65.
} 
explicitly with the concept of retributivism or with any unambiguously related idea. ${ }^{199}$ Perhaps this poll gave Fattah confidence to speak again in his letter about what "[t]he results of the polls ... would want us to believe."200 Yet that could not explain the use of the same type of phrase in his report, which had been completed long before this poll took place. ${ }^{201}$ Other polling data playing a key role in Fattah's discussion did draw attention to realities that might by implication have pointed toward retributive dynamics — although some of this data proved especially useful partly because it helped him to rebut a study emphasizing certain American citizens' utilitarian mentality. ${ }^{202}$

In any case, "the results of the polls" did not "want" to persuade Canadians to adopt any belief in particular; any desire to persuade lay with the research firms doing the work, or with the firms' individual personnel. However, perhaps in speaking of "polls" Fattah was referring not just to the work of research firms, but also to polling efforts or related investigative endeavours undertaken by certain academics in the course of preparing articles or research papers. ${ }^{203}$ And perhaps some of these academic authors might indeed have "wanted" to emphasize retributivism. In the Canadian context, the

\footnotetext{
${ }^{199}$ The poll query was as follows: "Last fall, the then Justice Minister, Otto Lang, remarked that 'what society wants is better law \& order and it may be satisfied with than [sic] instead of capital punishment'. If we can achieve better law \& order, would you or would you not be satisfied to see an end to the death penalty in Canada?" Affirmative answers, negative responses, and "can't say" comprised 41, 48, and 11 percent, respectively, of the total responses. See Canadian Institute of Public Opinion, " $48 \%$ Want Capital Punishment: Better Law \& Order Not Enough," news release (The Gallup Report), March 3, 1976.

${ }^{200}$ Ezzat A. Fattah, letter to the editor, Globe and Mail, June 7, 1976, p. 6.

${ }^{201}$ See House of Commons Debates (24 November 1975), 9369; see Canadian Institute of Public Opinion, "48\% Want Capital Punishment: Better Law \& Order Not Enough," news release (The Gallup Report), March 3, 1976.

${ }^{202}$ See Fattah, Study of a Social Attitude, 22, 47-48, 53-56, 65.

${ }^{203}$ For Fattah's discussion of two studies that seem to have dealt in part with or touched upon both retributivism and capital punishment, see ibid., 57, 60, 64. I do not know the exact research methodology of these studies.
} 
most relevant study involving such research methods was Vidmar's. ${ }^{204}$ And one suspects that Vidmar did in fact desire that retentionists acquire a somewhat retributive reputation. But Fattah's own wording gives plenty of reason to suspect that he desired the same thing, whether or not he would have admitted it. If retentionists possessed a retributive image, abolitionists would have an additional avenue for critique - for moral critique of the pro-death-penalty camp in case authorities remained skeptical of statements that downplayed the fervor of Canadian retentionism, or that called attention to the "uninformed" outlook or "irrational" mind-sets to which citizens might possibly subscribe. ${ }^{205}$

It is easy to believe that, in a great number of cases, to depict retentionists' prodeath-penalty perspective as a retributive viewpoint was indeed to portray matters accurately, as Vidmar and Fattah believed, whether or not the retentionists themselves would all have agreed. But the significance of these two academics' efforts to investigate and inform others about Canadians' attitudes with respect to the capital-punishment controversy does not lie only in the possible descriptive accuracy of their work. Vidmar and Fattah were not hoping solely to be mouthpieces for accurate description. They also hoped to add more horsepower to abolitionist moral claims.

"[T]he high priest of the movement in favour of abolition of capital punishment" - that,

\footnotetext{
${ }^{204}$ See ibid., 64-66; see also Vidmar, "Attitudes toward the Death Penalty," 341-344.

${ }^{205}$ For hints or more direct suggestions about such outlooks or mind-sets, see Fattah, Study of a Social Attitude, second page of Abstract, fifth page of Summary, 85-90, 92, 94 (only the second page of Abstract, fifth page of Summary, 88, and 92 contain either the term "uninformed" or the term "irrational").
} 
thought retentionist MP Jake Epp, might be an apt description of Ezzat Fattah. ${ }^{206}$ Such a moniker probably overstated Fattah's importance to the abolitionist cause. At the same time, Fattah's two reports had allowed him to give significant input concerning two of the particularly distinctive topics of the death-penalty debate in the 1970s: the seeming triumphs and tenacity of crime, on the one hand, and of the retentionist perspective, on the other. When Fattah's first report came off the press, abolitionists found that, dogged though they might be by murder statistics that hardly looked abolition-friendly, they nevertheless possessed the tools to argue viably that the abolitionist understanding of deterrence, murder, and capital punishment remained believable. The document proved to suit the 1970s rather well. The information and patterns of reasoning found within the report turned out, whether or not Fattah had expected this, to give some abolitionists a nudge of encouragement to think or speak from a vantage point to which other events and people already vigorously beckoned them - a vantage point promoting consciousness of the nation's "problem." Bodies were entering morgues because of some citizens' murderous conduct, but heartache would also spring from "the root of the problem,"207 from "the real problem," ${ }^{, 20}$ or from "the larger and ever increasing problem." 209 The ethos of the debate created plenty of space for references to "the real problem," or to multiple problems. If crime created more off-putting moments in 1970s Canadian life

\footnotetext{
${ }^{206}$ House of Commons Debates (28 May 1976), 13954 (Jake Epp, MP - Progressive Conservative, Provencher, MB).

${ }^{207}$ House of Commons Debates (28 May 1976), 13948 (Gilles Marceau, MP - Liberal, Lapointe, $\mathrm{QC)}$.

${ }^{208}$ Ibid; House of Commons Debates (3 May 1976), 13088 (Warren Allmand, MP - Liberal, Notre-Dame-de-Grâce, QC).

${ }^{209}$ House of Commons Debates (5 May 1976), 13207 (Norman Cafik, MP - Liberal, Ontario, ON).
} 
than citizens would have hoped, many retentionists and abolitionists were quite ready to supplement their troubled comments about crime with blunt words about allegedly related current phenomena: permissiveness, violence, unintelligent criminal justice. Such topics offered plenty of opportunities for debate participants to fire moral salvoes opportunities that a number of them seized.

Those looking for evidence of problems could find additional signals when ruminating upon the citizenry's outlook - a topic that also tended to generate further statements incorporating explicit or implicit moral ideas. "I do not believe," declared abolitionist Gerald Baldwin, "that ordinary Canadians are blood thirsty, violent or revengeful by nature." But by the same token, that meant "something must be wrong when such large numbers of people in this country wish to restore, or even think about restoring the practice of legal killing by hanging." As Baldwin saw it, "There is unease, anxiety and deep unrest abroad in this land."210 He was not the only observer who upon noting Canadians' retentionist preferences began seeking to identify the vexatious facets of life at this historical juncture. Fattah, for instance, did the same. ${ }^{211}$ And Baldwin's words, like Fattah's report and the other examples discussed in this chapter, also illustrated the potential for close interaction between debaters' ethical assumptions and their interpretation of retentionist citizens' outlook. The prevailing moral culture gave Canadians little reason to admire and strong reason to reproach those qualifying as "blood

\footnotetext{
${ }^{210}$ House of Commons Debates (29 May 1973), 4225 [see also 4226] (Gerald Baldwin, MP Progressive Conservative, Peace River, AB).

${ }^{211}$ See Fattah, Study of a Social Attitude, 3-6. See also House of Commons Debates (30 January 1973), 805 (Doug Rowland, MP - NDP, Selkirk, MB); (29 May 1973), 4214 (Joe Clark, MP - Progressive Conservative, Rocky Mountain, AB); (29 May 1973), 4227-4228 (Mark Rose, MP - NDP, Fraser Valley West, BC).
} 
thirsty, violent or revengeful." The idea that these adjectives might point to the truth about the retentionist camp certainly caught the attention of some debaters, perhaps especially those who had thoroughly bought into the moral culture of the day. And it was the type of idea that some of them felt the urge to talk about - perhaps with a little extra eagerness to spread the idea further, or with a little extra determination to stop it in its tracks, or with a little extra readiness to downplay it in order to give fellow citizens the benefit of the doubt. As many debate participants recognized, it was safe to assume that a few moral beliefs, assumptions, or preferences could be found in every rhetorical hand at the table. ${ }^{212}$ Few tricks could pass without such cards coming out into full view.

\footnotetext{
${ }^{212}$ See, for instance, House of Commons Debates (12 July 1976), 15241 (Joseph-Philippe Guay, MP - Liberal, St. Boniface, MB).
} 


\section{Chapter 6: Conclusion}

Canadian judges and correctional authorities who needed a little encouragement might not have been well advised to open the September 1975 issue of Saturday Night, especially not if they had bought into the federal government's present vision concerning sentencing and corrections. On this occasion the magazine contained some less-thancongratulatory thoughts about that vision, courtesy of journalist Barbara Amiel, author of a piece entitled "The Chaos of Criminal Justice in Canada. Or: In Defence of Vengeance." As Amiel saw it, "[v]engeance and retribution" had been left sitting in the dugout too much in the Canadian game of sentencing and punishment. Without these players in action, the team would not succeed on all counts. For instance, the authorities would face greater difficulty in the effort to keep Canadians "reassured and satisfied that society really did place some value on their persons," were it not to be true that "retribution followed injury" via criminal justice. ${ }^{2}$

Providing a "defence of vengeance" might have interested Amiel less had she had no "chaos" to write about. As she pointed out, "most Canadians would probably sacrifice their satisfaction in retribution and punishment if 'rehabilitation' would, as its advocates claim, protect them from recidivism." But throughout the article readers received the message that if rehabilitation were the home run that authorities intended every convict to hit, the crack of the bat accompanying a drive that would indeed fly over the outfield

\footnotetext{
${ }^{1}$ Barbara Amiel, "The Chaos of Criminal Justice in Canada. Or: In Defence of Vengeance," Saturday Night 90, no. 4 (September 1975): 19-26.

${ }^{2}$ Ibid., 19; see also 20, 22-23, 25.

${ }^{3}$ Ibid., 23.
} 
fence was heard far too rarely. Convicts may have possessed a metaphorical energy drink to put some vigour in their swings, but the people thanks to whom said liquid had become available - "social scientists," a group that received numerous dirty looks from Amiel — had proved themselves poor inventors in this instance. "Today we are faced with a choice," she declared. "We can cling to the idea that more of what we have unsuccessfully tried in the last century will work. Or we can go back to the theories of punishment and exile that existed before." Perhaps the topics of rehabilitation and deterrence might never give observers of Canadian criminal justice reason to stop feeling wistful and to start beaming triumphantly. But in stepping ahead with the second option Amiel had named, the judicial and penal systems could "[create] a sense of reassurance and satisfaction in society at large and ma[ke] it clear that certain actions [are] approved and others condemned."4

Although the term "instrumental" did not appear in Amiel's article, in one sense she was portraying instrumentalist penal perspectives as overrated. Admittedly, a good number of instrumentalist notes emerged in her own tune, and her efforts to cut "the rehabilitation programmes of social scientists"s down to size involved throwing punches at a specific type of penal instrumentalism, not at penal instrumentalism per se. But she did suggest that instrumentalism could not hurl sufficiently good anti-crime pitches for Canada to put it on the mound for the full nine innings while making retribution perpetually twiddle its thumbs in the bullpen. Furthermore, the final paragraphs of the

${ }^{4}$ Ibid., 19-20.

SIbid., 21. 
article contained some polemical words suggesting that Amiel found a solely

instrumentalist penal vision to be inherently repelling:

Regardless of whether punishment deters or rehabilitates, it is necessary for justice. When [Solicitor General] Warren Allmand was asked whether vengeance was an element of justice he was shocked: 'No, no, of course not,' he replied. But of course vengeance is as much a part of justice as mercy. Without either, society would have only passionless sanctions of utility, the most dehumanizing approach of all, the approach of scientists to rats in a Skinner maze.

Ultimately, in such a dispassionate paradise of bureaucrats, there would be neither love nor hate, neither vengeance nor mercy, only preventive regulations. ${ }^{6}$

Amiel made little room in her article for references to the death penalty, and the brief notice that she did give the phenomenon seemed to be in an uncomplimentary vein.? But at least a few people considered her piece pertinent to the controversy, ${ }^{8}$ and it is relevant to the present thesis as well. As discussed in the introductory chapter, important analyses pertaining to the mentality that facilitated abolition in Canada can be found within studies by David Chandler and Carolyn Strange. The reader examining Chandler's scholarship might emerge ready to count "instrumentalist" among the primary adjectives applicable to this mentality. ${ }^{9}$ Exploring Strange's work might encourage us to consider "proceduralist" - a term connected in important respects with "instrumentalist" - to be

${ }^{6}$ Ibid., 25.

${ }^{7}$ See ibid., 25; see also 19.

${ }^{8}$ For what appear to be pieces of verbatim text from or very close paraphrases of statements from Amiel's article, used extensively in two retentionist speeches, al though seemingly with no indication of her as a source, see House of Commons Debates (11 May 1976), 13422-13424 (Lloyd Crouse, MP Progressive Conservative, South Shore, NS); (26 May 1976), 13874-13875 (Walter Dinsdale, MP Progressive Conservative, Brandon-Souris, MB). For a document explicitly referencing the article, see Canada, Ministry of the Solicitor General, Questions and Answers, Question No. 67.

${ }^{9}$ Note that I am not aware of any places in which the actual term "instrumentalist" appears in Chandler's study (a Google ${ }^{\mathrm{TM}}$ Book Search of the book revealed none). He does use the term "instrumental." See Chandler, Capital Punishment in Canada, xxii-xxiii, 4-6, 24, 28-29, 53, 141. As discussed in the opening chapter, it is abolitionists, not all Canadians, whom Chandler puts in the ofteninstrumental camp. 
a second key descriptor. ${ }^{10}$ However, despite the instrumental and procedural dynamics

that become visible in abolition-related historical developments thanks to these authors'

analyses, both writers do also point to a sort of double-mindedness existing in Canadian

culture with respect to punishment. If such terms as "procedural," "instrumental," and

"regulatory" describe the sorts of dynamics that Canadians often considered to be ideal

for penal affairs, at other times the criminal-justice dynamics that citizens preferred

deserved quite different descriptors, such as "expressive" or "spectacular."11 Amiel's

article illustrates this second facet of the double-minded phenomenon. The piece serves

as a reminder not only that in no period have all Canadians' penal preferences been of

instrumentalist stripe, ${ }^{12}$ but also that certain instrumentalist penal perspectives were

perhaps especially unlikely to get through the early-to-mid-1970s without at least some

citizen-inflicted bruises, given the "frustration" and "anxiety" of these years, to use terms

employed by MPs. ${ }^{13}$ Amiel herself noted citizens' hotter-than-normal mid-1970s temper

\footnotetext{
${ }^{10}$ See Strange, "Undercurrents," 349, 353-365, 383-384; see also Strange, "Lottery of Death," 597, 599-600, 617-619; see also footnote 32 in Chapter 1. Note that the term "proceduralist" may not appear in Strange's studies. She does use "procedural," at least in "Undercurrents." On the connections between the procedural and the instrumental, see Taylor, Sources of the Self, 21, 174.

${ }^{11}$ See Strange, "Lottery of Death," 597, 617-619; see Chandler, Capital Punishment in Canada, 205-206 n. 53; see also Strange, "Undercurrents," 349, 383-385. The terms "regulatory" and "spectacular" are found in the first Strange article, "procedural" in the second, and "instrumental" and "expressive" in Chandler's work. Although this concluding chapter does not provide any further discussion of the role of proceduralism in the death-penalty controversy, I do not thereby mean to imply that proceduralism did not act as a key ingredient in capital-punishment-related historical developments. Instead, the absence of further discussion of this dynamic simply reflects the fact that the thesis as a whole specifically focuses on the role that moral perspectives and rhetoric played in the debate, rather than on the role of proceduralism.

${ }^{12}$ For discussion that perhaps creates a similar impression to my statement, although perhaps without meaning quite the same as what I have said, see Strange, "Lottery of Death," 597, 619; Strange, "Undercurrents," 385.

${ }^{13}$ For "frustration," see, for example, House of Commons Debates (31 January 1973), 847-848 (Ed Nelson, MP - NDP, Burnaby-Seymour, BC); (12 July 1976), 15238 (J.P. Nowlan, MP - Progressive Conservative, Annapolis Valley, NS). For "anxiety," see House of Commons Debates (29 May 1973), 4225-4226 (Gerald Baldwin, MP - Progressive Conservative, Peace River, AB). My description here is stimulated partly by David Garland's discussion of the in-many-respects-similar dynamics in the United
} 
with respect to criminal and penal affairs, portraying this reality as indicative of the relevance of her piece. ${ }^{14}$ As evidence presented in Chapter 5 reveals, it is partially thanks to this "anxiety" that the death-penalty debate acquired certain new dynamics in the 1970s. Indeed, this thesis has attempted to highlight some of the ideas and occurrences — ideas and occurrences both generating and generated by this "anxiety" - that helped to produce the distinctiveness of the 1970s debate vis-à-vis the debate in the earlier portions of the period of study. ${ }^{15}$

But neither the 1970s nor Barbara Amiel would lead all citizens to believe that instrumentalism needed to spend a little less time on the criminal-justice pitcher's mound. An Amiel-rebutting letter to the editor in the December 1975 edition of Saturday Night reveals one of the important factors that helps to explain why not. Reader James $\mathrm{S}$. Peterson seemed to hail from instrumentalist territory when he described, apparently in approval, the "three guides in sentencing criminals" that "Canada and other civilized countries use": he spoke of "protecting society," of "deterring," of "rehabilitating." $\mathrm{He}$ did grant the "obvious" truth "that our present system of criminal justice has certain shortcomings, and changes are necessary." To Peterson, though, recognition of such realities "merely demonstrate[s] the need to reform sentencing, parole, and prisons, a task the government is now undertaking." Although he seemed to feel that his apparently

\footnotetext{
States and Britain during this period and subsequent decades - see Garland, Culture of Control, including 96-97, 132-135, 140-154.

${ }^{14}$ See Amiel, "In Defence of Vengeance," 22, 25.

${ }^{15}$ For a discussion that helped to stimulate and possesses many parallels to the final two sentences and to the second half of this paragraph (but that does not address all of the same issues that I do here), see House of Commons Debates (29 May 1973), 4225-4226 (Gerald Baldwin, MP - Progressive Conservative, Peace River, AB).
} 
instrumentalist penal vision needed no help from retributive relief pitchers, he did not think this solely because of that vision's attractiveness in its own right. His stance also reflected his positive opposition to Amiel's retributive counter-vision, an opposition that in turn partly reflected the moral culture of the time. Peterson's own ethical perspective concerning vengeance seems clear from the phenomena to which he broadly compared it. "Does [Amiel] mean," he asked,

that efficacy of criminal sentences should be determined, at least in part, by the quantum of vengeful satisfaction produced? Does she also mean the state should pander to other human shortcomings such as racial, religious, linguistic and sexual bigotry, aggression, hostility, etc.?

Moreover, he appears to have believed that other Canadians would find that the type of penal practices Amiel preferred, which might turn out to qualify as "sadistic or inhumane," provoked a rebuke from their own "conscience[s]," leaving them more disaffected with judicial and penal affairs than ever. As he phrased it, "her concepts would engender the contempt for justice that results when conscience dictates rejection of a sadistic or inhumane system."16 In sum, whether Peterson considered instrumentalist penal perspectives themselves to be wonderful or merely reasonably hardy, he appears in any case to have considered them the best option, with his own and others' ethical viewpoints providing key content for the letter of decline that would have to be sent in reply to any retributive offers.

\footnotetext{
${ }^{16}$ James S. Peterson, letter to the editor, Saturday Night 90, no. 7 (December 1975): 4. Although the phrasing of the last quotation is somewhat confusing to me, I believe I have correctly interpreted its meaning. The longer context of this quotation is as follows: "Parliament's major problem during this reform process will be in not overreacting to the system's present inadequacies. To introduce vengeance and retribution, as Ms. Amiel preaches, would not increase the sense of responsibility she says is necessary for an orderly society that respects individual freedoms. Rather, her concepts would engender the contempt for justice that results when conscience dictates rejection of a sadistic or inhumane system."
} 
Although Peterson's letter said nothing concerning capital punishment, it did deal with issues pertinent to the controversy over this sanction, and it points toward a major theme in this thesis: that moral assumptions and claims actually contributed a good deal of the inspiration leading to or of the message conveyed by those arguments, viewpoints, and analyses that placed major emphasis upon instrumentalist ideas or empirical claims. ${ }^{17}$ Chapter 2 reveals the complementarity between death-penalty debaters' moral outlook, on the one hand, and their decision to discuss the instrumentalist topic of deterrence so much, on the other, with the first having done much to make the second seem appropriate and vital. In addition, at various points the thesis provides examples of arguments in which both instrumentalist and ethical ideas emerged, with the two sometimes bearing a close resemblance to one another. And Chapter 5 reveals certain instances in which academics' largely empirical exploration and discussion of death-penalty-related phenomena also conveyed moral notions. All in all, if instrumentalist ideas sprinted flashily around the track of the capital-punishment debate, moral assumptions remained right behind, pacing their sometimes more noticeable fellow runners.

However, the thesis does not merely reveal the admittedly unsurprising fact that the movement of debaters' lips or the scribbling of their pens was usually in some way or another putting some variety of moral energy into action, even when seemingly instrumentalist words emerged from the effort. Rather, the cumulative evidence also provides some idea about what type of moral beliefs characterized the culture of the day,

\footnotetext{
${ }^{17}$ For one of the statements in the House of Commons that made a similar point to mine, see House of Commons Debates (12 July 1976), 15241 (Joseph-Phillippe Guay, MP - Liberal, St. Boniface, MB).
} 
primarily with respect to the death-penalty controversy in particular, but perhaps also to some extent with respect to morality in general. At least a few observers writing during the period itself provided some big-picture reflections concerning the general moral perspective of the current culture. ${ }^{18}$ For instance, in an August 18, 1976 opinion piece, the Toronto Star's Robert Nielsen discussed the phenomenon of morality and, in a farfrom-congratulatory vein, the Western world's current mentality concerning it. Among other things, he noted the cultural preference for deferring conversations about morality until some later occasion, pointed out a weakness in the moral pedagogy used with certain Canadian schoolchildren, and highlighted the pertinence of "moral restraints" or lack thereof to certain aspects of violent conflict. The agnostic Nielsen was pensive in his closing words: "it does seem that when man no longer recognizes moral rules as emanating from a source higher than himself, mankind falls into moral confusion and apathy." 19

Nielsen's article did not mention capital punishment, and perhaps he might have said something quite different had he been discussing morality in the context of that controversy. However, his words provide an apt segue into an analysis here of the characteristics of the then-prevailing moral culture that seem to be revealed through the Canadian death-penalty debate. Some debaters at the time and some Canadians in subsequent years - the present writer among them — have believed that to stop

\footnotetext{
${ }^{18}$ For one small example, see John B. Woodger, letter to the editor, Globe and Mail, February 25 , 1960, p. 6.

${ }^{19}$ Robert Nielsen, "Intentions May Be Good, But No Morality in Terrorism," Toronto Star, August 18,1976 , p. B4.
} 
"recogniz[ing] moral rules as emanating from a source higher than" humanity ${ }^{20}$ does indeed do people ill, and also constitutes — happily - a mistaken judgment. But although in certain respects the facets of Canadian moral culture relevant to the deathpenalty debate reflected dynamics similar to those that Nielsen's closing sentence described, in other respects his statement would not apply well to the debate.

For instance, this thesis has revealed that if a moral argument possessed allegedly transcendent credentials, that did not necessarily mean that its exponents would find that their words seemed convincing to most of their listeners, especially not if the argument strongly promoted retributive notions or Old Testament scriptural assertions. Still, despite this weakened cultural credibility of transcendently oriented moral thinking, it is not clear how many debaters could truly have been said to have "no longer recognize[d] moral rules as emanating from a source higher than" the human species. ${ }^{21}$ Admittedly, on at least a few occasions debaters did make statements conveying this type of humanfocused outlook fairly clearly. ${ }^{22}$ And by the early 1970 s this description may indeed have accurately captured the perspective of over half of the citizenry, if the small amount of relevant evidence acquired in the process of one investigation does not create a misleading impression. ${ }^{23}$ But even in those speeches or letters that contained some kind

${ }^{20}$ Tbid.

${ }^{21}$ Ibid.

${ }^{22}$ See J.K. Payne, letter to the editor, Globe and Mail, April 23, 1958, p. 6; W.R. Williams, letter to the editor, Globe and Mail, January 11, 1960, p. 6; Arthur W. Ghent, letter to the editor, Globe and Mail, February 27, 1960, p. 6; J.M. Cohoe, letter to the editor, Globe and Mail, March 10, 1960, p. 6; P. Carberry, letter to the editor, Globe and Mail, March 1, 1965, p. 6.

${ }^{23}$ Slightly fewer than 150 southern Ontarians whose opinions on capital-punishment-related issues were investigated in 1973 faced a question regarding how "the morals of 'right and wrong' are determined," with the two possible answers being "(a) by man, and the moral values may vary from time to time" or "(b) God determines moral values and they are absolute, or by man, but moral values are absolute." Not quite two thirds selected the first option, while slightly more than one third selected the second - Vidmar, 
of hint about a given debater's assumptions concerning this issue, ambiguity often remained.

The debate might possibly have witnessed the emergence of "moral confusion" in some respects. Nevertheless, perhaps it is more useful not to posit a great deal of conscious confusion per se, but rather to emphasize simply that the alleged weaknesses or possible falsity of certain key moral ideas did hit home with many debaters, although often without generating a sense of full certainty that these moral ideas truly did miss the mark. Debaters' viewpoints on retribution-related notions exemplified these dynamics particularly clearly. ${ }^{24}$ As some abolitionists saw it, retentionists' statements concerning "justice" or "retribution" needed to stem a little less from pleasant imagination and a little more from accurate perception of the phenomena in question. In reciting past events and circumstances and envisioning new ones yet to come, people had no good cause to imagine that the latter would perfectly replicate the former. The same, thought at least a few abolitionists, could be said about justice, that "relative concept which changes with the times. ${ }^{25}$ Moreover, some abolitionists believed that if an investigator were to hunt down the person or entity at whose behest the capital-punishment tradition claimed for

\footnotetext{
"Attitudes toward the Death Penalty," 346; see also 342-343, 350.

${ }^{24}$ For an analysis that is somewhat different from what I have said here, but that provides at least a partial sense of the dynamics that I am postulating, especially with respect to retribution, see the comments in a speech by MP John Tumer - House of Commons Debates (14 November 1967), 4251-4253 (John Turner, MP - Liberal, St. Lawrence-St. George, QC).

${ }^{25}$ Sellin, "Capital Punishment: An Address," 39 (see also 38); House of Commons Debates (5 April 1966), 3876 (Donald Ross Tolmie, MP — Liberal, Welland, ON); see also LAC, MG32, Series B27 (Marcel Lambert fonds), Volume 81, File 7 - File Title: "Capital Punishment 1966," The Canadian Society for the Abolition of the Death Penalty, Information Bulletin 2 (panel discussion held in the Confederation Room, Parliament Buildings [West Block] at Ottawa on Thursday, June 3, 1965) (Toronto: Canadian Society for the Abolition of the Death Penalty, 1965), 24, 29-30 (speech by René Lévesque and English translation of same).
} 
itself the retributive notions termed "justice," "retribution," and so forth, he would wind up pointing the finger not at "a moral order in the universe," psyches of citizens, not least the psyches of those participating in the death-penalty debate. ${ }^{27}$ As one letter in the Toronto Star put it, "vociferous" retentionists' "cruel advocacy derives, not from their innate sense of justice, but rather, from their own repressed aggression as it seeks a socially acceptable victim.." ${ }^{28}$ To assume that a full consensus in favour of such a viewpoint existed among debaters would certainly be a mistake. But palpably retributive ideas did also receive the cold shoulder from a number of retentionists. And when a sentiment concerning the reprehensibility of murderers tingled on retentionists' tongues, it sometimes emerged not as a component of a straightforwardly retributive claim, but rather as an observation offered or connotation conveyed while ruminating upon murder victims, or while incorporating verbal images of animality into a discussion about killers. In sum, various particulars of the debate revealed that in debaters' estimation, retributive moral notions bore a suspicious odor suspicious either to themselves or to their listeners.

If some retentionists did not want to make too many explicitly retributive noises when pointing out murderers' reprehensibility, various abolitionists suspected that even

\footnotetext{
${ }^{26}$ For this quoted phrase, see LAC, MG32, Series B35 (Walter Gilbert Dinsdale fonds), Volume 79, File 2 - File Title: "Capital Punishment. General 1973," Ken Campbell, "Why Capital Punishment Ought To Be Retained: Another Christian View," [1972 or later].

${ }^{27}$ See especially D.R. Morgan, letter to the editor, Globe and Mail, February 23, 1960, p. 6; along related, though a little different, lines, see J.K. Payne, letter to the editor, Globe and Mail, April 23, 1958, p. 6, Aaron Carbell, letter to the editor, Globe and Mail, February 25, 1960, p. 6, and "Passerby," letter to the editor, Toronto Daily Star, February 18, 1961, p. 6; see also David M. Blackwell, letter to the editor, Toronto Star, February 21, 1973, p. 7.

${ }^{28}$ A.D. Lakeman, letter to the editor, Toronto Star, July 19, 1975, p. B3.
} 
such claims about killers' blameworthiness could sometimes add another mark to the tally of retentionists' inaccuracies. Here was a second type of moral idea whose potential weaknesses remained in some debaters' line of sight: the idea of human responsibility. As we have seen, some abolitionists thought that if murder investigators had been able to jump into an omniscience machine for a minute, they would in many cases have emerged quite ready to write "mentally ill" beside the killer's name when analyzing the lethal event. To others, as to MP Marke Raines, "[t]hese people on death row are the product of our society; and if these people have failed, our society in a measure has failed as well."29 Many abolitionists who possessed such views probably believed that hasty references to human responsibility might not facilitate a very successful, or even a tolerably successful, effort to describe a murderer accurately. Some abolitionists, it should be noted, seemed to suggest that a killer's nerves and sinews might well have tingled with the invigoration of volition and responsibility to some extent, but that the task of verifying and quantifying this phenomenon would simply stymie either authorities or other observers. ${ }^{30}$ Still, abolitionist rhetoric sometimes included the announcement that "no sympathy"31 or "misguided sense of sympathy for"32 killers bulged in abolitionist pockets - the type of statement that seemed to imply at least a little responsibility and blameworthiness on the

\footnotetext{
${ }^{29}$ House of Commons Debates (25 May 1976), 13802 (Marke Raines, MP - Liberal, BurnabySeymour, BC).

${ }^{30}$ See, for example, Eric Nicol, quoted in House of Commons Debates (5 May 1976), 13221 (Ursula Appolloni, MP - Liberal, York South, ON). I have not identified the Nicol writing from which Appolloni was quoting.

${ }^{31}$ Arthur Maloney, "Does Retention Protect Police?" The Canadian Register (Kingston, ON), February 5, 1966, p. 5 (a clipping of this article is found in LAC, MG32, Series C31 [Heath Nelson Macquarrie fonds], Volume 42, File 32 - File Title: "Capital Punishment 1966"); House of Commons Debates (30 January 1973), 804 (Jack Cullen, MP - Liberal, Sarnia-Lambton, ON). Haldimand, ON).

${ }^{32}$ House of Commons Debates (9 November 1967), 4077 (Larry Pennell, MP - Liberal, Brant-
} 
killers' part. In short, allusions to murderers' immorality sometimes appeared even in abolitionist argument, thereby hinting at the ambiguity in abolitionists' perspective on murderers and responsibility. But at least some debaters believed that those who planned to offer the adjective "responsible" as one of the key descriptors of a killer needed, at the least, to exercise careful thought and employ cautious words.

However, if the debate at times revealed the weakness of debaters' adherence to certain moral ideas, in other respects it demonstrated to what a great degree ethical issues lit debaters' fire. While it is not clear in how many cases a debater could have been said to have "no longer recognize[d] moral rules as emanating from a source higher than himself,"33 it does seem clear that debaters' expectations concerning themselves served as a key catalyst enabling their ethical outlook to coalesce. Indeed, such expectations greatly facilitated the promotion of alternative moral claims when dissatisfaction or perplexity arose regarding certain moral ideas pertaining to retribution or responsibility. Abolitionist discourse exemplified this dynamic most clearly. Although some abolitionists suspected that the responsibility which a murderer would, morally speaking, have to acknowledge might not actually be too extensive, this did not mean that they wished to go on a non-responsibility and amorality campaign. Whatever they might have suspected about murderers, abolitionists seem to have tended to expect to hear their own names in the roll call of persons for whom the full-blooded version of moral responsibility was mandatory. We have also seen that some abolitionists, perhaps

\footnotetext{
${ }^{33}$ Robert Nielsen, "Intentions May Be Good, But No Morality in Terrorism," Toronto Star, August 18, 1976, p. B4.
} 
partially because they actually saw a good deal of plausibility in the idea of murderers' blameworthiness, considered it necessary for anti-capital-punishment argument to emphasize something other than "pity for hardened killers."34 Instead, anti-death-penalty discourse could warn that Canadians themselves, including abolitionists, would end up gritting their teeth due to a moral sprained ankle should the nation implement an actively retentionist version of criminal justice. An abolitionist Canada, by contrast, would offer good prospects for the more normal moral invigoration that abolitionists — and, they presumed, other citizens as well — would prefer to feel within their limbs. Furthermore, if in the context of capital punishment "“[s]ociety's just retribution"” disappointingly turned out to embody euphemistically such phenomena as "[o]ur latent hatreds, our suppressed anger, our wish to have revenge, ${ }^{, 35}$ that in itself could remind abolitionists of the urgency of another moral belief to which they adhered: namely, that the cord of vengeful energy needed to be lying unplugged in their souls whenever their actions, words, or lack thereof formed part of or helped to activate a punishment - especially if it were of a lethal variety.

It is not clear whether a similar dissatisfaction at the thought of making room in their own lives for morally substandard attitudes and practices characterized many abolitionists' perspective on issues other than the death penalty. Perhaps they used abolitionist arguments that implied rigorous moral objectives for their own character

\footnotetext{
${ }^{34}$ For this four-word quotation, see Arthur Maloney, "Does Retention Protect Police?" The Canadian Register (Kingston, ON), February 5, 1966, p. 5 (a clipping of this article is found in LAC, MG32, Series C31 [Heath Nelson Macquarrie fonds], Volume 42, File 32 - File Title: "Capital Punishment 1966").

${ }^{35}$ D.R. Morgan, letter to the editor, Globe and Mail, February 23, 1960, p. 6.
} 
primarily because they thought that cultural assumptions of the time provided good prospects for such arguments to achieve rhetorical success. But in any case, in the deathpenalty debate various abolitionists assumed that arguments pertaining to their own duties, decisions, and character possessed a significant moral bite, even if the same could not necessarily be said about claims dealing with the moral assessment of non-"normal" persons like killers.

To hark back to Nielsen's closing words, debaters may have found contemplation of themselves to be crucial to their moral decision-making, and some shivers of "moral confusion" may well have twitched in their minds or souls. However, for a great many of those participating in the public debate, either a spelled-out ethical vision or less solidly outlined but still insistent moral preferences made it difficult for "apathy" to wrap its drowsy arms around them.

If words about "a moral order in the universe"36 or some comparably transcendent concept did not seem to some debaters to provide the full dose of persuasive energy that they were seeking for their own ruminations or for their advocacy to others concerning death-penalty-related moral issues, this did not mean that they could find the necessary additional persuasive power only by pointing to the moral expectations that they as individuals happened to retain for their own selves, or to other people's expectations of themselves. Rather, a number of debaters believed that those hoping to make a correct and convincing ethical decision concerning the death penalty could help themselves out a

\footnotetext{
${ }^{36}$ LAC, MG32, Series B35 (Walter Gilbert Dinsdale fonds), Volume 79, File 2 - File Title: "Capital Punishment. General 1973," Ken Campbell, "Why Capital Punishment Ought To Be Retained: Another Christian View," [1972 or later].
} 
great deal by recalling the progress to which all citizens were or ought to be party by virtue of partaking in human existence or civilization, and by virtue of participating in the phenomenon of history. ${ }^{37}$ Although this thesis has provided only a modest amount of analysis concerning debaters' progress-themed arguments, the variety of appearances that this theme made in their advocacy does indeed confirm its importance to a good number of debaters. Approximations of the theme could emerge when debaters spoke of animality and humanness, ${ }^{38}$ offered claims relating to scriptural material, ${ }^{39}$ discussed historical-structural exigencies with respect to capital punishment and other homicidal practices, ${ }^{40}$ mentioned twentieth-century technology, ${ }^{41}$ and so forth.

Not all who spoke of progress would necessarily have been eager to do so as strongly as abolitionist MP John Gilbert, although at least some others did indeed make statements comparable to his claim that "history ... shows mankind as moving from barbarism to enlightenment."42 But in any case, this familiar phrase points to the familiar conceptual pattern to which many debaters' moral outlook did in certain respects run parallel. On the one hand, attending to the vision of progress brought awareness of "barbarism," of the less-than-admirable ways in which people could act and live actions and ways of life that long-departed eras had, it was believed, been especially able

\footnotetext{
${ }^{37}$ For one example, see House of Commons Debates (24 March 1966), 3101-3103 (Gérard Pelletier, MP - Liberal, Hochelaga, QC).

${ }^{38}$ See House of Commons Debates (20 February 1973), 1483-1484 (Ed Nelson, MP - NDP, Burnaby-Seymour, BC).

${ }^{39}$ See House of Commons Debates (6 May 1976), 13259 (John Gilbert, MP - NDP, Broadview, ON).

${ }^{40}$ See House of Commons Debates (24 March 1966), 3101-3103 (Gérard Pelletier, MP - Liberal, Hochelaga, QC).

${ }^{41}$ See House of Commons Debates (14 November 1967), 4265 (Stanley Knowles, MP - NDP, Winnipeg North Centre, MB).

${ }^{42}$ House of Commons Debates (23 July 1973), 5886 (John Gilbert, MP - NDP, Broadview, ON).
} 
to claim as their own, but that persons of the present might unfortunately try on for size as well. Accordingly, sounds of reprehension concerning certain perspectives on the death penalty could sometimes reach Canadians' ears via debaters' implicitly progress-related statements. We have seen, for example, a few of the cases in which abolitionists' critical characterizations of retribution, of execution, or of the revenge allegedly embodied therein were designed to strike home with listeners or readers partly by means of the terms "primitive" ${ }^{43}$ or "savagery." 44

On the other hand, many of debaters' progress-positing statements were of the sort that have given the term "progress" its reputation as an encouraging word. The human realm already featured many practices and attitudes far more encouraging than the types that had obtained in previous times, believed numerous debaters. Moreover, Canadians had no obligation to be too cautious in their anticipation of additional "enlightenment" or similar progress-related positives. This type of assumption could make anti-capitalpunishment debaters readier to apply the same type of idea to abolition that Larry Pennell articulated concerning the abolition-friendly Bill C-84 in 1967: that it "represents one more step in the continuing march toward a higher regard for human life." ${ }^{\text {45 }}$ NDP leader David Lewis was suggesting something similar when he spoke about "the progress of

\footnotetext{
${ }^{43}$ For additional examples, see C.J. Vincent, letter to the editor, Globe and Mail, January 10, 1963, p. 6; see House of Commons Debates (24 March 1964), 1421 (Reid Scott, MP - NDP, Danforth, ON); (16 November 1967), 4369 (Lester Pearson, MP - Liberal, Algoma East, ON); Jeff Barnard, letter to the editor, Toronto Daily Star, June 23, 1969, p. 6; Carol A. Reed, letter to the editor, Toronto Star, September 17, 1975, p. B5.

${ }^{44}$ For another such example, see (Rev.) J. Franklin Chidsey, letter to the editor, Globe and Mail, April 23, 1958, p. 6.

${ }^{45}$ House of Commons Debates (9 November 1967), 4082 (Larry Pennell, MP - Liberal, BrantHaldimand, $\mathrm{ON}$ ).
} 
civilization in societies like our own." Lewis posited "progress in all directions of human behaviour, man to man and collectively, man to the creator." Indeed, he believed,

historically, philosophically and morally, mankind in civilized society has been progressing away from the taking of human life by the state, by individual human beings and on a world scale. Continually and progressively, mankind has recognized the dignity of the human being and the sacredness of the human life. ${ }^{46}$

As this "progress" or "continuing march" sank into their hearers' minds, believed such abolitionists, the doubtful faces that these listeners might formerly have worn during discussion of ethics and abolition ought to morph into countenances calmed with proabolition moral decisiveness.

Furthermore, as Chapter 4 suggests in its discussion of abolitionist rhetoric concerning animality and humanness, not only people's ethical outlook but also their actual identity could coalesce partly around a narrative that progress-themed assumptions did much to weave - a dynamic whereby additional invigoration emerged in each component of the identity-narrative-ethics triangle. At more than one level, then, debaters could equip themselves for judgment of and advocacy concerning death-penaltyrelated ethical questions by accepting or employing progress-related ideas or arguments, whether of a descriptive or exhortatory genre.

Perhaps it is useful to follow up this discussion of debaters' progress-related arguments with some very brief and admittedly speculative thoughts concerning the possible contrasts between the moral culture existing in late-1950s-to-mid-1970s Canada

${ }^{46}$ House of Commons Debates (16 May 1973), 3846 (David Lewis, MP - NDP, York South, ON). For another good example, see House of Commons Debates (23 May 1973), 4039 (John Harney, MP NDP, Scarborough West, ON). 
and those of preceding and subsequent periods. It seems likely that what this thesis has called transcendently oriented moral thinking was at least somewhat more in vogue for much of earlier Canadian history than it was in the period examined here. For that matter, the House of Commons might have heard a greater amount of exuberantly progress-themed rhetoric in some earlier times as well. But one also suspects that at least some of the progress-related claims or allusions seen in the death-penalty debate during the 1960s and 1970s might emerge slightly less readily if such a debate were to occur at the present time. Perhaps the term "primitive" might not surface in pejorative statements, for example $;{ }^{47}$ people also might offer less enthusiastic phrases than "[p]rogress in all directions"48 or "the long-term improvement of mankind."49 Instead, arguments would probably make at least a little more frequent mention of human rights, for instance $-\mathbf{a}$ theme largely absent from the debate during the period studied here. But if explicit and convinced progress-themed moral arguments might now emanate from people's mouths less often, one also suspects that this change would have been rather less likely to occur had they not found themselves capable of expending their moral energy by means of other conceptual and rhetorical implements, such as human-rights themes. ${ }^{50}$

At least that is what we would suspect if we have not changed too dramatically since the mid-1970s. After all, this thesis has highlighted the continual emergence of

\footnotetext{
${ }^{47}$ I owe this idea to Dr. Jim Opp of Carleton University, based on a verbal comment he made along similar though slightly different lines following a paper presentation.

${ }^{48}$ House of Commons Debates (16 May 1973), 3846 (David Lewis, MP - NDP, York South, ON).

${ }^{49}$ House of Commons Debates (26 May 1976), 13861 (Stuart Leggatt, MP - NDP, New Westminster, BC).

${ }^{50}$ For a discussion which seems at least to imply that people's willingness to dispense with existing "moral sources" is contingent upon their possession of seemingly viable alternatives, see Taylor, Sources of the Self, 310-313.
} 
such moral energy, not only in the most full-throated claims of thoroughgoingly confident adherents of transcendently oriented or progress-focused moral perspectives, but in a wide variety of discourse, some of it pointing obliquely to moral notions that in explicit form did not jibe well with cultural expectations, but which debaters wished, consciously or not, to communicate in at least some manner. Admittedly, such dynamics are unsurprising, and to point them out is less than profound. But to borrow the observation of one present Canadian thinker, sometimes the obvious things are what need to be said. ${ }^{51}$

${ }^{51} \mathrm{I}$ believe this is a near-quote of a statement made by Mark Kingwell at a public lecture I attended at the Vancouver Public Library in the fall of 2003. The words in my memory are "it's the obvious things that need to be said" - I could, of course, be mistaken on the wording. 


\section{Bibliography}

\section{PRIMARY SOURCES:}

\section{Archival Sources}

\section{$\underline{\text { Library and Archives Canada }}$}

Alvin Hamilton fonds, MG32, Series B40

Canadian Committee on Corrections sous-fonds, RG36, Series 24

Canadian Council of Churches fonds, MG28, Series 1327

E. Davie Fulton fonds, MG32, Series B11

Francis Andrew Brewin fonds, MG32, Series C26

Heath Nelson Macquarrie fonds, MG32, Series C31

Herbert W. Herridge fonds, MG32, Series C13

June Callwood fonds, MG31, Series K24

Lester B. Pearson fonds, MG26, Series N2

Marcel Lambert fonds, MG32, Series B27

Privy Council Office, RG2, Series A-5-a, Cabinet Conclusions. This source was searched and consulted online through the Library and Archives Canada Web site. The search page is located at http://www.collectionscanada.ca/archivianet/conclusions/001039-100.01-e.html.

Richard Albert Bell fonds, MG32, Series B1

Walter Gilbert Dinsdale fonds, MG32, Series B35

\section{Newspapers}

Brandon Daily Sun (Brandon, MB) 
Globe and Mail - This newspaper was primarily consulted by means of its online digital archive, accessed through the Carleton University Library.

Montreal Gazette

Ottawa Citizen

Ottawa Journal

Le Soleil (Quebec City)

Toronto Daily Star - This newspaper was primarily consulted by means of its online digital archive, accessed through the Carleton University Library.

Vancouver Sun

\section{Government Documents}

An Act to amend the Criminal Code (Capital Murder), S.C. 1960-61, c. 44.

An Act to amend the Criminal Code, S.C. 1967-68, c. 15.

An Act to amend the Criminal Code, S.C. 1973-74, c. 38.

An Act to amend the Criminal Code in relation to the punishment for murder and certain other serious offences, S.C. 1974-75-76, c. 105.

Canada. Department of Justice. Capital Punishment: Material Relating to Its Purpose and Value. Ottawa: Queen's Printer, 1965.

Canada. Dominion Bureau of Statistics. Judicial Division. Murder Statistics: 1970. Ottawa: Information Canada, 1971.

Canada. House of Commons Debates. Ottawa: Queen's Printer.

Canada. Joint Committee of the Senate and the House of Commons on Capital and Corporal Punishment and Lotteries. Minutes of Proceedings and Evidence, No. 14 (18-19 May 1954). Ottawa: Queen's Printer, 1954.

Canada. Ministry of the Solicitor General. Questions and Answers Relating to the Capital Punishment Issue. Ottawa: 1976. 
Canada. Reports of the Joint Committee of the Senate and House of Commons on Capital and Corporal Punishment and Lotteries. Ottawa: Queen's Printer, 1956.

Canada. Report of the Royal Commission to Investigate the Penal System of Canada. Ottawa: King's Printer, 1938.

Canada. Statistics Canada. Justice Statistics Division. Paul Reed, Teresa Bleszynski, and Robert Gaucher. Homicide in Canada: A Statistical Synopsis. Ottawa: [Queen's Printer], 1976.

Canada. Statistics Canada. Justice Statistics Division. Homicide Statistics: 1976. Ottawa, [Supply and Services Canada], 1978.

Canada. Statistics Canada. Judicial Division. Murder Statistics: 1971. Ottawa: Information Canada, 1973.

Canada. Statistics Canada. Justice Statistics Division. Murder Statistics: 1975. Ottawa, [Queen's Printer], 1976.

Fattah, Ezzat A. The Canadian Public and the Death Penalty: A Study of a Social Attitude. [Ottawa, ON?], [1976].

-. A Study of the Deterrent Effect of Capital Punishment with Special Reference to the Canadian Situation. Ottawa: Information Canada, 1972.

Hann, Robert G. Deterrence and the Death Penalty: A Critical Review of the Research of Isaac Ehrlich ("A Research Report prepared under contract with the Research Division of the Solicitor General of Canada"). Ottawa: 1976.

Journals of the House of Commons of Canada. Ottawa: Queen's Printer.

\section{Published Primary Sources}

"The Abolition of Capital Punishment." Canadian Bar Review 32, no. 5 (May 1954): 485-519.

Amiel, Barbara. "The Chaos of Criminal Justice in Canada. Or: In Defence of Vengeance." Saturday Night 90, no. 4 (September 1975): 19-26.

Aquinas, Thomas. Summa Theologiae. Vol. 38, Injustice. Edited and translated by Marcus Lefébure, O.P. New York: Blackfriars / McGraw-Hill Book Company; London: Blackfriars / Eyre \& Spottiswoode, 1975. 
Bell, Don. "There Wouldn't Be Crime without Victims." The Globe and Mail Weekend Magazine 22, no. 29 (July 15, 1972): 18-19.

Board of Evangelism and Social Service, the United Church of Canada. Alternatives to Capital Punishment: Full Text of the Report of the Committee on Alternatives to Capital Punishment to the Nineteenth General Council of the United Church of Canada, September 1960, Edmonton, Alberta. Toronto: Board of Evangelism and Social Service, the United Church of Canada, [1960].

Camus, Albert. "Reflections on the Guillotine." Translated by Justin O'Brien. In Albert Camus, The Plague, The Fall, Exile and the Kingdom and Selected Essays, introduction by David Bellos, 609-656. New York, NY: Alfred A. Knopf, 2004.

Canadian Criminology and Corrections Association. The Death Penalty: An Official Statement of Policy of the Canadian Criminology and Corrections Association. November 1972.

Canadian Institute of Public Opinion. "48\% Want Capital Punishment: Better Law \& Order Not Enough." News release (The Gallup Report), March 3, 1976.

-. "61\% Blame Society for Crime Rather Than the Individual." News release (The Gallup Report), March 17, 1976.

-. "63\% Want Death Penalty Restored for Murderers." News release (The Gallup Report), February 2, 1972.

-. "Canadian Public Not Ready to Abolish Death Penalty." News release (The Gallup Report), February 23, 1966.

—. "Canadians Not Ready to Abolish Capital Punishment." News release (The Gallup Report), April 16, 1975.

-. "Canadians Still in Majority for Keeping Death Penalty." News release (The Gallup Report), February 24, 1965.

-. "Crime Blamed on Society Rather Than the Individual." News release (The Gallup Report), April 7, 1971.

-. "Large Majority of Canadians Still Favor Capital Punishment." News release (The Gallup Report), August 6, 1977.

-. "Most Don't Know MP's Vote on Capital Punishment." News release (The Gallup Report), September 22, 1976. 
The Canadian Society for the Abolition of the Death Penalty. Information Bulletin 1. [Toronto, ON]: The Canadian Society for the Abolition of the Death Penalty, [1964].

-. Information Bulletin 2 (panel discussion held in the Confederation Room, Parliament Buildings [West Block] at Ottawa on Thursday, June 3, 1965). Toronto: Canadian Society for the Abolition of the Death Penalty, 1965.

Dailey, Thomas. "Theology and the Death Penalty." The Inkhorn 2:2 (Spring/Summer 1975): 1-8.

Department of Christian Social Service. Anglican Church of Canada. The Death Penalty? Toronto: Department of Christian Social Service, Anglican Church of Canada, n.d. [1965?].

Ehrlich, Isaac. "The Deterrent Effect of Capital Punishment: A Question of Life and Death." American Economic Review 65, no. 3 (June 1975): 397-417.

Gowers, Ernest. A Life for a Life? The Problem of Capital Punishment. London: Chatto and Windus, 1956.

Hatfield, L.F. "A Study of Capital Punishment." The Bulletin (Council for Social Service, The Church of England in Canada) No. 163 (January 10, 1955): 5-15.

Hurlburt, W.H. Letter to the editor. Chitty's Law Journal 20, no. 6 (June 1972): 181-183.

Kelly, John. "Love All Men as We Love Ourselves," Gazette (The Law Society of Upper Canada) 9, no. 4 (December 1975): 291-296.

Lewis, C.S. "The Humanitarian Theory of Punishment." Chitty's Law Journal 20, no. 1 (January 1972): 1-5.

Menninger, Karl. The Crime of Punishment. New York: The Viking Press, 1968.

Morton, J.D. The Function of Criminal Law in 1962: Five Lectures for Radio in the Series CBC University of the Air. Toronto: Canadian Broadcasting Corporation, 1962.

—. "Murder Most Foul." Canadian Bar Journal 2, no. 2 (April 1959): 114-120.

Peterson, James S. Letter to the editor. Saturday Night 90, no. 7 (December 1975): 4.

Sellin, Thorsten. "Capital Punishment: An Address Delivered at a Rally Sponsored by the 
Canadian Society for the Abolition of the Death Penalty, February 7, 1965." Criminal Law Quarterly 8, no. 1 (June 1965): 36-51.

Shaw, Bernard. Everybody's Political What's What? $2^{\text {nd }}$ ed. 1945; repr., London, UK: Constable and Company Limited, 1950.

Summerhayes, T.F. "Capital Punishment for Murder." The Bulletin (Council for Social Service, The Church of England in Canada) No. 163 (January 10, 1955): 2-4.

Taylor, E.L.H. "The Christian and the Modern World," His Dominion 11, no. 1 (February 1, 1962): 15-25.

—. "Christ's Interpretation of His Own Death." His Dominion 10, no. 2 (May 1, 1961): 18-24.

—. Economics, Money and Banking. Nutley, NJ: The Craig Press, 1978.

-. "Medicine or Morals as the Basis of Justice and Law." In Essays on the Death Penalty, ed. T. Robert Ingram, 81-102. 1963; repr., Houston, TX: St. Thomas Press, 1971.

-. Reformation or Revolution: A Study of Modern Society in the Light of a Reformational and Scriptural Pluralism. Nutley, NJ: The Craig Press, 1970.

- "Retribution, Responsibility and Freedom: The Fallacy of Modern Criminal Law from a Biblical-Christian Perspective." Law and Contemporary Problems 44, no. 2 (Spring 1981): 51-82. http://www.jstor.org/.

-. "A Secular Revolution in Christian Disguise." Canadian Bar Journal 1, no. 4 (August 1958): 41-46, 81-82.

-. "Should the Death Penalty Be Retained in Canada? A Review of the Argument." His Dominion 9, no. 2 (May 1, 1960): 17-24.

Taylor, Hebden. Evolution and the Reformation of Biology: A Study of the Biological Thought of Herman Dooyeweerd of Amsterdam and J.J. Duyvene de Wit, late Professor of Zoology at the University of Bloemfontein, South Africa. Nutley, NJ: The Craig Press, 1967.

-. The New Legality in the Light of the Christian Philosophy of Law. Philadelphia: Presbyterian and Reformed Publishing Company, 1967.

Temple, William. “The Ethics of Punishment: A (Reprint)." The Bulletin (The Council 
for Social Service, The Anglican Church of Canada) No. 165 (October 15, 1956): $1-4$.

Vidmar, Neil. "Retributive and Utilitarian Motives and Other Correlates of Canadian Attitudes toward the Death Penalty." Canadian Psychologist 15, no. 4 (October 1974): 337-356.

\section{SECONDARY SOURCES:}

\section{Theses}

Arron, Mark, "Punishment and Civilization: A Case Study of the Canadian Capital Punishment Debate of 1987." M.A. Thesis, University of Manitoba, 1994. Ottawa: National Library of Canada, 1995.

Bureau, Mathieu. "L'Abolition de la Peine de Mort au Canada: Le Discours Politique et L'Opinion Publique lors des Débats de 1966-1967, 1973 et 1976." M.A. Thesis, Université de Sherbrooke, 2000. Ottawa: National Library of Canada, [2002]. http://www.collectionscanada.ca/obj/s4/f2/dsk2/ftp03/MQ61721.pdf.

Chenier, Elise Rose. "Stranger in Our Midst: Male Sexual 'Deviance' in Postwar Ontario." Ph.D. Thesis, Queen's University, 2001. Ottawa: National Library of Canada, [2002].

http://www.collectionscanada.ca/obj/s4/f2/dsk3/ftp05/NQ63412.pdf.

Meyer, Jeffrey. "Evaluating the Punitive Turn Thesis: Is Canadian Penal Discourse Officially Exemplifying a Punitive Mentality?" M.A. Thesis, Carleton University, 2004.

Seagrave, Jayne. "The Death Penalty: Will Canada or Britain Restore This Punishment?" M.A. Thesis, University of Ottawa, 1986.

White-Mair, Kimberley. "Negotiating Responsibility: Representations of Criminality and Mind-State in Canadian Law, Medicine and Society, 1920-1950." Ph.D. Thesis, University of Toronto, 2001. Ottawa: National Library of Canada, [2002]. http://www.collectionscanada.ca/obj/s4/f2/dsk3/ftp04/NQ63613.pdf.

\section{Books and Articles}

Avio, Kenneth L. "The Quality of Mercy: Exercise of the Royal Prerogative in Canada." 
Canadian Public Policy 13, no. 3 (1987): 366-379.

Banner, Stuart. The Death Penalty: An American History. Cambridge, MA: Harvard University Press, 2002.

Bothwell, Robert, Ian Drummond, and John English. Canada Since 1945: Power, Politics, and Provincialism. Revised Edition. Toronto: University of Toronto Press, 1989.

Chandler, David B. Capital Punishment in Canada: A Sociological Study of Repressive Law. Toronto: McClelland and Stewart Limited, 1976.

Chesterton, G.K. Orthodoxy. Introduction by Philip Yancey. 1908; this edition, New York, NY: Image Books, Doubleday, 2001.

Curti, Merle. Human Nature in American Thought: A History. Madison, WI: University of Wisconsin Press, 1980.

"Edmund Morris, 1924-2003," The Times (St. Mary's University, Halifax, Nova Scotia) 34, no. 1 (April 2003), http://www.smu.ca/thetimes/t2003-04/morris.html (accessed December 12, 2006).

Ekstedt, John W., and Curt T. Griffiths. Corrections in Canada: Policy and Practice. Toronto: Butterworths, 1984.

Elias, Norbert. The Civilizing Process: Sociogenetic and Psychogenetic Investigations. Revised edition. Translated by Edmund Jephcott with some notes and corrections by author. Edited by Eric Dunning, Johan Goudsblom, and Stephen Mennell. Oxford, UK: Blackwell Publishers, 2000.

Evans, Richard J. Rituals of Retribution: Capital Punishment in Germany, 1600-1987. Oxford: Oxford University Press, 1996.

Friedland, Paul. "Beyond Deterrence: Cadavers, Effigies, Animals and the Logic of Executions in Premodern France." Historical Reflections/Réflexions Historiques 29, no. 2 (Summer 2003): 295-317.

Garland, David. The Culture of Control: Crime and Social Order in Contemporary Society. Chicago: University of Chicago Press, 2001.

-.Punishment and Welfare: A History of Penal Strategies. Aldershot, Hants, England; Brookfield, Vermont: Gower, 1985. 
Garnett, Richard W. "Final Justice." Review of The Death Penalty, by Stuart Banner, and The Contradictions of American Capital Punishment, by Franklin E. Zimring. America: The National Catholic Weekly 189, no. 13 (October 27, 2003). http://www.americamagazine.org/content/article.cfm?article_id=3244 (accessed April 29, 2006).

Gatrell, V.A.C. The Hanging Tree: Execution and the English People, 1770-1868. Oxford, UK: Oxford University Press, 1994.

Habermas, Jürgen. "Are There Postmetaphysical Answers to the Question: What is the 'Good Life'?' In The Future of Human Nature, 1-15. This essay translated by William Rehg. Cambridge, UK: Polity Press, 2003.

Haskell, Thomas L. "Capitalism and the Origins of the Humanitarian Sensibility, Part 1." American Historical Review 90, no. 2 (April 1985): 339-361.

-. "Capitalism and the Origins of the Humanitarian Sensibility, Part 2." American Historical Review 90, no. 3 (June 1985): 547-566.

Hébert, Jacques. I Accuse the Assassins of Coffin. Montreal: Les Éditions du Jour, 1964.

Hunter, James Davison. Culture Wars: The Struggle to Define America. [New York]: Basic Books, 1991.

Jacoby, Susan. Wild Justice: The Evolution of Revenge. New York: Harper \& Row, 1983.

Jayewardene, C.H.S. "The Canadian Movement Against the Death Penalty." Canadian Journal of Criminology and Corrections 14 (1972): 366-390.

-. The Penalty of Death: The Canadian Experiment. Lexington, MA: Lexington Books, D.C. Heath and Company, 1977.

LeBourdais, Isabel. The Trial of Steven Truscott. Philadelphia, PA, and New York, NY: J.B. Lippincott Company, 1966.

Lewis, C.S. God in the Dock: Essays on Theology and Ethics. Edited by Walter Hooper. Grand Rapids, Michigan: William B. Eerdmans Publishing Company, 1970.

Loo, Tina. "Savage Mercy: Native Culture and the Modification of Capital Punishment in Nineteenth-Century British Columbia." In Qualities of Mercy: Justice, Punishment, and Discretion, ed. Carolyn Strange, 104-129. Vancouver: UBC Press, 1996. 
MacIntyre, Alasdair. After Virtue: A Study in Moral Theory. $2^{\text {nd }}$ ed. 1984 [1 $1^{\text {st }}$ ed 1981]; repr., Notre Dame, Indiana: University of Notre Dame Press, 2003.

Masur, Louis. Rites of Execution: Capital Punishment and the Transformation of American Culture, 1776-1865. New York, NY: Oxford University Press, 1989.

Mattingly, Terry. "Ten Years of Reporting on a Fault Line." Terry Mattingly on Religion column. http://tmatt.gospelcom.net/column/1998/04/15/ (accessed July 31, 2007).

McGowen, Randall. "History, Culture and the Death Penalty: The British Debates, 184070.” Historical Reflections/Réflexions Historiques 29, no. 2 (Summer 2003): 229249.

McKillop, A.B. A Disciplined Intelligence: Critical Inquiry and Canadian Thought in the Victorian Era. Carleton Library Series 193. Montreal \& Kingston: McGillQueen's University Press, 2001.

Megivern, James J. The Death Penalty: An Historical and Theological Survey. New York/Mahwah, NJ: Paulist Press, 1997.

Melton, J. Gordon, ed. The Churches Speak on: Capital Punishment: Official Statements from Religious Bodies and Ecumenical Organizations. Detroit: Gale Research Inc., 1989.

Mitchell, Tom. "'Blood with the Taint of Cain': Immigrant Labouring Children, Manitoba Politics, and the Execution of Emily Hilda Blake." Journal of Canadian Studies 28, no. 4 (1993-4): 49-71.

Nye, Robert. "Two Capital Punishment Debates in France: 1908 and 1981." Historical Reflections/ Réflexions Historiques 29, no. 2 (Summer 2003): 211-228.

Oliver, Peter. 'Terror to Evil-Doers': Prisons and Punishment in Nineteenth-Century Ontario. Toronto: University of Toronto Press, 1998.

Owram, Doug. Born at the Right Time: A History of the Baby-Boom Generation. Toronto: University of Toronto Press, 1996.

Pasquino, Pasquale. "Criminology: The Birth of a Special Savoir." Translated by Colin Gordon. In The Origins and Growth of Criminology: Essays on Intellectual History, 1760-1945, ed. Piers Beirne, 131-146. Aldershot, Hants, England; Brookfield, Vermont: Dartmouth Publishing Company Limited, 1994.

Pojman, Louis P. "For the Death Penalty." In Louis P. Pojman and Jeffrey Reiman, The 
Death Penalty: For and Against, 1-66. Lanham, MD: Rowman \& Littlefield Publishers, 1998.

Potter, Harry. Hanging in Judgment: Religion and the Death Penalty in England from the Bloody Code to Abolition. London: SCM Press Ltd., 1993.

Pullen, Charles. The Life and Times of Arthur Maloney: The Last of the Tribunes. Toronto: Dundurn Press, 1994.

Randle, Judith. "The Cultural Lives of Capital Punishment in the United States." In The Cultural Lives of Capital Punishment: Comparative Perspectives, ed. Austin Sarat and Christian Boulanger, 92-111. Stanford, CA: Stanford University Press, 2005.

Reiman, Jeffrey. "Why the Death Penalty Should Be Abolished in America." In Louis P. Pojman and Jeffrey Reiman, The Death Penalty: For and Against, 67-132. Lanham, MD: Rowman \& Littlefield Publishers, 1998.

Sher, Julian. "Until You Are Dead": Steven Truscott's Long Ride into History. Research assistance by Theresa Burke. Toronto, ON: Alfred A. Knopf Canada, 2001.

Smith, Cameron. Unfinished Journey: The Lewis Family. Toronto: Summerhill Press, 1989.

Stackhouse, Reginald. The Way Forward: A History of Wycliffe College, Toronto, 18772002. [Toronto: Wycliffe College?], 2002.

Strange, Carolyn. "Discretionary Justice: Political Culture and the Death Penalty in New South Wales and Ontario, 1890-1920." In Qualities of Mercy: Justice, Punishment, and Discretion, ed. Carolyn Strange, 130-165. Vancouver: UBC Press, 1996.

-. "The Half-Life of the Death Penalty: Public Memory in Australia and Canada." Australian Canadian Studies 19, no. 2 (2001): 81-99.

-. "Introduction." In Qualities of Mercy: Justice, Punishment, and Discretion, ed. Carolyn Strange, 3-20. Vancouver: UBC Press, 1996.

- . "The Lottery of Death: Capital Punishment, 1867-1976." Manitoba Law Journal 23, no. 3 (January 1996): 594-619.

- " "The Undercurrents of Penal Culture: Punishment of the Body in Mid- TwentiethCentury Canada." Law and History Review 19, no. 2 (2001): 343-385. 
Swainger, Jonathan. "A Distant Edge of Authority: Capital Punishment and the Prerogative of Mercy in British Columbia, 1872-1880." In Essays in the History of Canadian Law, Volume VI: British Columbia and the Yukon, ed. Hamar Foster and John McLaren, 204-241. Toronto: University of Toronto Press, 1995.

Taylor, Charles. Sources of the Self: The Making of the Modern Identity. Cambridge, Massachusetts: Harvard University Press, 1989.

Wolfgang, Marvin E. "Thorsten Sellin (26 October 1896 - 17 September 1994)." Proceedings of the American Philosophical Society 140, no. 4 (December 1996): 580-586. http://www.jstor.org/.

\section{Web Sites}

Centre on Values \& Ethics, Carleton University, Web site. http://www.carleton.ca/cove/.

Dordt College Web site. "History."

http://www.dordt.edu/about/our_philosophy/history.shtml.

Dordt College Web site. "Our Philosophy." http://www.dordt.edu/about/our_philosophy/

Mattingly, Terry. "Dang it, there's that question again." Weblog post, June 6, 2006, GetReligion.org. http://www.getreligion.org/?m=200606\&paged=4 (accessed July 31,2007 )

Parliament of Canada Web site. "Members of the House of Commons" (page containing historical information). http://www2.parl.gc.ca/Parlinfo/Lists/Members.aspx?Parliament=0d5d5236-70f04a7e-8c96-68f985128af9.

The Suburban Times. Obituaries. Rev. E.L. Hebden Taylor, September 3, 2006. http://www.thesubtimes.com/2006/09/obituaries.html (accessed November 25, 2006).

\section{Reference Works}

Canadian Encyclopedia online.

http://www.thecanadianencyclopedia.com/index.cfm?PgNm=HomePage\&Params $=\mathrm{A} 1$

The Canadian Who's Who, vol. VIII, 1958-1960. Toronto: Trans-Canada Press, 1960. 
The Canadian Who's Who, vol. IX, 1961-1963. Toronto: Trans-Canada Press, 1963.

The Canadian Who's Who, vol. X, 1964-1966. Toronto: Trans-Canada Press, 1966.

The Canadian Who's Who, vol. XI, 1967-1969. Toronto: Who's Who Canadian Publications, 1969.

Dictionary of Basilian Biography: Lives of Members of the Congregation of Priests of Saint Basil from Its Origins in 1822 to 2002. Second Edition, Revised and augmented by P. Wallace Platt. Toronto: University of Toronto Press, 2005.

Encyclopedia of Music in Canada.

http://www.thecanadianencyclopedia.com/index.cfm?PgNm=EMCSubjects\&Para $\mathrm{ms}=\mathrm{U} 1$.

Who's Who in Canada, 1962-63. Ed. B.M. Greene. Associate ed. G.W. Stratton. Toronto: International Press Limited, 1962. 